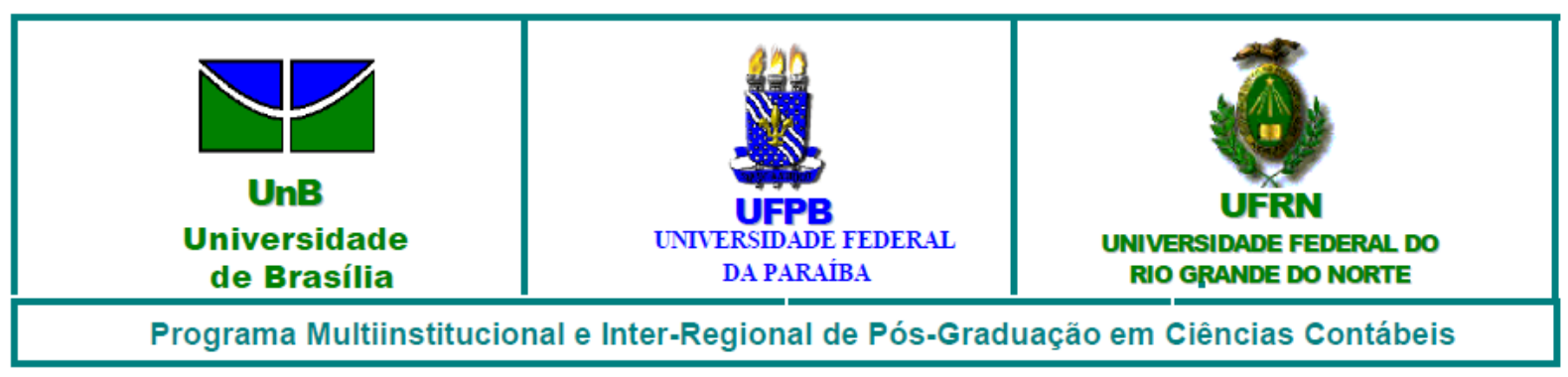

A AMPLITUDE DE PARTICIPAÇÃO SOCIAL DOS CONSELHOS ESTADUAIS DE SAÚDE DA REGIÃO CENTRO OESTE COMO POSSÍVEL FATOR DE INCREMENTO DA QUALIDADE DAS PRESTAÇÕES DE CONTAS DAS SECRETARIAS ESTADUAIS DE SAÚDE

TIAGO JOSÉ GONZAGA BORGES

\title{
BRASÍLIA
}


UNIVERSIDADE DE BRASÍLIA - UnB

\author{
Reitor: \\ Professor Doutor Ivan Marques de Toledo Camargo \\ Vice-Reitor: \\ Professor Doutora Sônia Nair Báo \\ Decano de Pesquisa e Pós-Graduação: \\ Professor Doutor Jaime Martins de Santana
}

Diretor da Faculdade de Economia, Administração e Contabilidade:

Professor Doutor Roberto de Goes Ellery Junior

Chefe do Departamento de Ciências Contábeis e Atuariais:

Professor Doutor José Antônio de França

Coordenador Geral do Programa Multi-institucional e Inter-regional de Pós Graduação em Ciências Contábeis da UnB, UFPB e UFRN

Professor Doutor Rodrigo de Souza Gonçalves 


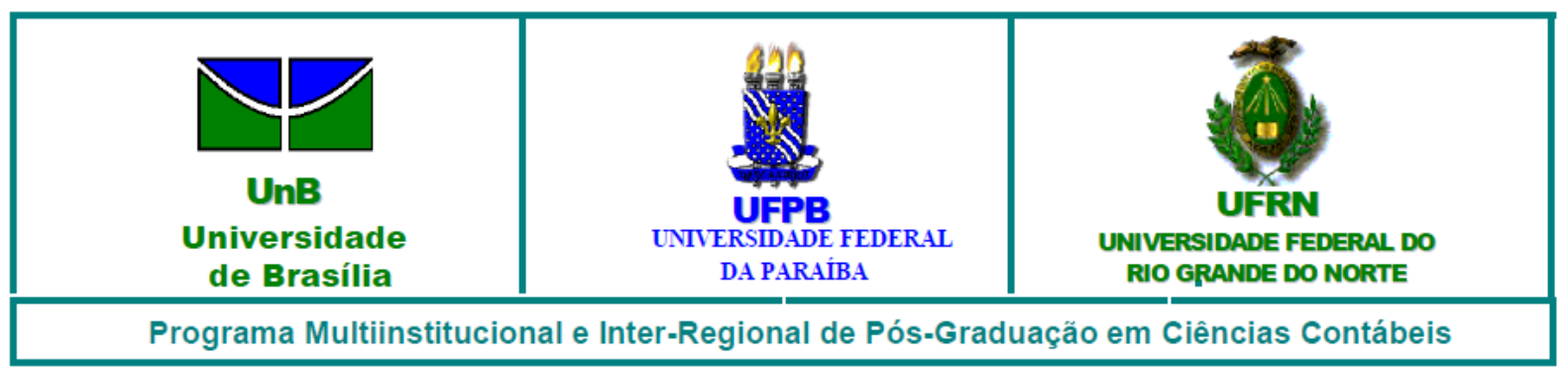

TIAGO JOSÉ GONZAGA BORGES

\section{A AMPLITUDE DE PARTICIPAÇÃO SOCIAL DOS CONSELHOS ESTADUAIS DE SAÚDE DA REGIÃO CENTRO OESTE COMO POSSÍVEL FATOR DE INCREMENTO DA QUALIDADE DAS PRESTAÇÕES DE CONTAS DAS SECRETARIAS ESTADUAIS DE SAÚDE}

Dissertação apresentada como requisito parcial à obtenção do título de Mestre em Ciências Contábeis do Programa Multi-institucional e Inter-Regional de Pós-Graduação em Ciências Contábeis da Universidade de Brasília, da Universidade Federal da Paraíba e da Universidade Federal do Rio Grande do Norte.

Linha de Pesquisa: Impactos da Contabilidade na Sociedade

Grupo de Pesquisa: Gestão de Serviços Públicos.

\section{Orientador:}

Prof. Dr. Rodrigo de Souza Gonçalves

BRASÍLIA 
Borges, Tiago José Gonzaga

A Amplitude de Participação Social dos Conselhos de Saúde da Região Centro Oeste Como Possível Fator de Incremento da Qualidade das Prestações de Contas das Secretarias Estaduais de Saúde./ Tiago José Gonzaga Borges - Brasília, DF, 2015.

$206 \mathrm{f}$.

Orientador: Prof. Dr. Rodrigo de Souza Gonçalves

Dissertação (mestrado) - Universidade de Brasília. Faculdade de Economia, Administração e Ciências Contábeis e Atuariais - FACE. Programa Multi-institucional e Inter-Regional de Pós-Graduação em Ciências Contábeis (UnB/UFPB/UFRN).

1. Amplitude de Participação Social. 2. Accountability. 3. Características Qualitativas da Informação Contábil. 4. Conselhos Estaduais de Saúde. I. GONÇALVES, Rodrigo de Souza. II. Universidade de Brasília. III. Universidade Federal da Paraíba. IV. Universidade Federal do Rio Grande do Norte. 


\section{A AMPLITUDE DE PARTICIPAÇÃO SOCIAL DOS CONSELHOS ESTADUAIS DE SAÚDE DA REGIÃO CENTRO OESTE COMO POSSÍVEL FATOR DE INCREMENTO DA QUALIDADE DAS PRESTAÇÕES DE CONTAS DAS SECRETARIAS ESTADUAIS DE SAÚDE}

\begin{abstract}
Dissertação apresentada como requisito parcial à obtenção do título de Mestre em Ciências Contábeis do Programa Multi-institucional e Inter-Regional de Pós-Graduação em Ciências Contábeis da Universidade de Brasília, da Universidade Federal da Paraíba e da Universidade Federal do Rio Grande do Norte.
\end{abstract}

Comissão Avaliadora:

\section{Prof. Dr. Rodrigo de Souza Gonçalves}

Programa Multi-institucional e Inter-regional de Pós-Graduação em Ciências Contábeis da UnB/UFPB/ UFRN

(Presidente da Banca)

\section{Prof $^{\mathrm{a}}$. Dra . Andréa de Oliveira Gonçalves}

Programa de Pós-Graduação em Gestão Pública da Universidade de Brasília (Membro Examinador Externo)

\section{Prof $^{\mathrm{a}}$. Dra . Maria Raquel Gomes Maia Pires}

Programa de Pós-Graduação em Gestão Pública da Universidade de Brasília (Membro Examinador Externo)

Brasília, 30 de março de 2015 
Ao meu pai-Raimundo Romão Borges (in memoriam) 


\section{AGRADECIMENTOS}

O primeiro e maior agradecimento é a Deus, responsável pela consecução do crescimento, aprendizado e felicidade alcançada neste e em outros momentos da minha vida. Agradeço ao meu pai terreno, Raimundo Romão Borges, pelo exemplo de vida que me foi passado. À minha família pelo apoio dado nos momentos mais difíceis dessa caminhada, que, por sinal, me trouxe muitos ensinamentos. O amadurecimento da fase "Mestrado" é algo singular.

Aos professores do Programa Multiinstitucional e Inter-regional de Pós Graduação em Ciências Contábeis UnB / UFPB / UFRN, em especial, ao meu orientador, Rodrigo de Souza Gonçalves, pela dedicação, paciência e atenção empregadas neste trabalho. Também não poderia esquecer dos conselhos dados, inclusive para a vida fora da academia. Agradeço também, em especial, aos professores César Augusto Tibúrcio Silva, Jorge Katsumi Niyama e Paulo Roberto Lustosa, grandes fontes de inspiração para minha vida pessoal e para vida acadêmica. Agradeço também à professora Andréa Gonçalves de Oliveira pelos ensinamentos e pela abertura de espaço, na disciplina cursada no Campus de Planaltina/DF, para um campo ainda inexplorado por mim - a Administração Pública.

Agradeço aos servidores Inez, Rodolfo e Sara, da secretaria de curso, pela atenção e presteza dedicada a mim e aos outros alunos nestes dois anos.

Agradeço também aos colegas de mestrado pelos incontáveis momentos de alegria, preocupação e por tudo mais. Seguramente foram momentos que me ajudaram a crescer na vida. Ao amigo e ex-colega de mestrado, Wolney Resende de Oliveira, por ter visto em mim características de "aluno de mestrado" e, por consequência, ter me incentivado ingressar no programa.

Agradeço ao CNPQ, via grupo de Pesquisa de Gestão de Serviços Públicos de Saúde da UnB, por ter viabilizado a pesquisa em outros Estados.

Por fim, gostaria de agradecer imensamente à mulher que se tornou a pessoa mais importante da minha vida, minha futura esposa, Vanessa Rodrigues de Araújo, pelo carinho, companheirismo, compreensão e amor dedicados a mim. Eu te admiro e me sinto muito feliz por ter alguém como você na minha vida. Obrigado por tudo! 
"Eu sei que é difícil esperar, mas Deus tem um tempo para agir e pra curar. Só é preciso confiar... Não desista do amor, não desista de amar, não entrega a dor porque ela um dia vai passar.

(Pe. Fabio de Melo). 


\section{RESUMO}

A discussão do controle social permeia várias áreas, mas para esta pesquisa se ateve à saúde pública na região Centro Oeste. Sob esse invólucro, salienta-se que o controle de gastos da gestão da saúde deve ocorrer por meio da fiscalização e controle dos Conselhos de Saúde no tocante aos relatórios de prestação de contas produzidos pelas Secretarias Estaduais de Saúde. Contudo, para a consecução do controle de gastos é preciso que haja participação social dos Conselhos (instâncias que representam usuários, trabalhadores da saúde, gestores e prestadores de serviço) - no sentido de compelir o gestor a prestar contas de seus atos. Não obstante, frisase a necessidade dos relatórios de prestação de contas estarem revestidos pelos aspectos qualitativos da informação contábil, ou seja, de possuírem uma qualidade que proporcione melhor entendimento do seu usuário. Para tanto, buscou-se verificar se a partir de uma maior amplitude de participação social haveria um incremento na qualidade dos relatórios. A avaliação da tendência de amplitude de participação social foi analisada a partir do instrumento de pesquisa formulado por Silva (1999) e baseado em Rifkin et al. (1989) e Demo (2001). Ademais, foram realizadas 27 entrevistas com conselheiros estaduais de saúde divididos entre Goiás, Mato Grosso e Mato Grosso do Sul, nove para cada um. Além disso, foram analisadas as atas das reuniões plenárias para avaliar a perspectiva histórica de criação e formação do Conselho até o período da pesquisa. Com respeito à qualidade da informação contábil procedeuse à análise documental das prestações de contas das Secretarias de Saúde do período de 2011 a 2013 com base no instrumento construído por Gonçalves et al. (2010). De maneira geral, ao analisar a qualidade da informação - considerando o conjunto de variáveis divulgadas de forma obrigatória e voluntária - verificou-se que os gestores de Goiás e Mato Grosso cumpriram praticamente só o que é imposto por legislação, demonstrando, dessa forma, que a participação dos Conselhos não foi qualificada a ponto de compelir o gestor a ser mais transparente em relação aos seus atos. A ausência da divulgação de informações voluntárias reforça a ideia de que a participação não qualificada pode tender a diminuir a qualidade dos relatórios. Já em Mato Grosso do Sul foi possível perceber que, em razão de um ambiente de maior participação e controle, há um espaço que propicia um incremento na qualidade dos relatórios. Diante do exposto, verificou-se que uma maior amplitude participação social pode incrementar a qualidade dos relatórios de prestações de contas.

Palavras-chaves: Amplitude da Participação Social. Accountability. Qualidade da Informação Contábil. Conselhos de Saúde. 


\begin{abstract}
The discussion of social control permeates many areas, but this research focused in public health in the Midwest region. In this casing, it is pointed that the control of health management expenses should occur through the supervision and control of the Health Councils with regard to accountability reports produced by State Health Departments. However, to attainment cost control there must be social participation of the Councils (instances representing users, health workers, managers and service providers) - to compel the manager to show their own actions. Nevertheless, the need of accountability reports are coated by the qualitative aspects of accounting information, in other words, of having a quality that provides better understanding for users. Therefore, this work sought to determine whether from a greater range of social participation would be an increase in the quality of reports. The assessment of social participation amplitude trend was analyzed from the survey instrument made by Silva (1999), based on Rifkin et al. (1989) and DEMO (2001). In addition, there were 27 interviews with State Health Counselors divided between the states of Goiás, Mato Grosso and Mato Grosso do Sul, nine for each state. This work also analyzed the minutes of the plenary meetings to evaluate the historical perspective of creation and formation of the Council until this survey period. Regarding the quality of accounting information, proceeded to the documentary analysis of accountability reports of Health Departments for 2011 to 2013 based on the instrument built by Gonçalves et al. (2010). In general, when analyzing the quality of information - considering the disclosed set of variables mandatory and voluntary - it was found that managers of Goiás and Mato Grosso met nearly only what is imposed by law, demonstrating, thus, that the participation of the councils was not qualified as to compel the manager to be more transparent about their actions. The absence of voluntary disclosure information reinforces. In Mato Grosso do Sul, in turn, it was observed that due to a greater participation and control environment there is a space that provides an increase in the quality of reports.
\end{abstract}

Keywords: Social Participation Range, Accountability, Characteristics of Accounting Information, Health Councils. 


\section{LISTA DE GRÁFICOS}

Gráfico 1 - Tendência dos indicadores de amplitude de participação dos CES.

Gráfico 2 - Tendência das categorias teóricas - qualidade da informação dos relatórios (SES/GO) 153

Gráfico 3 - Tendência das categorias teóricas da qualidade dos relatórios por ano (SES/GO). 154

Gráfico 4 - Tendência das categorias teóricas - qualidade da informação dos relatórios (SES/MT). 155

Gráfico 5 - Tendência das categorias teóricas da qualidade dos relatórios por ano (SES/MT).

Gráfico 6 - Tendência das categorias teóricas - qualidade da informação dos relatórios (SES/MS).

Gráfico 7 - Tendência das categorias teóricas da qualidade dos relatórios por ano (SES/MS). 158

Gráfico 8 - Diagrama da qualidade da informação das SES do Centro Oeste. 159

Gráfico 9 - Amplitude de participação social vs qualidade da informação - Goiás. 163

Gráfico 10 - Amplitude de participação social vs Qualidade da Informação - Mato Grosso.

Gráfico 11 - Amplitude de participação social vs Qualidade da Informação - Mato Grosso do Sul. 


\section{LISTA DE ILUSTRAÇÕES}

Figura 1 - Característica Qualitativas Fundamentais..........................................................56

Figura 2 - Características Qualitativas de Melhoria............................................................. 60

Figura 3 - Resumo esquemático da dimensão histórica.....................................................69 


\section{LISTA DE QUADROS}

Quadro 1 - Resumo esquemático do instrumento de pesquisa - Amplitude da Participação.. 64

Quadro 2 - Resumo esquemático do instrumento de pesquisa - Amplitude da Participação..65

Quadro 3 - Roteiro da entrevista semiestruturada para realizar com o conselheiro mais antigo do CES 71

Quadro 4 - Atas disponíveis para análise nos Conselhos de Saúde. 72

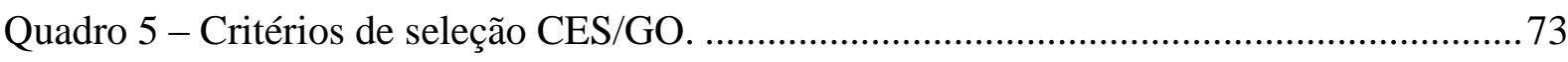

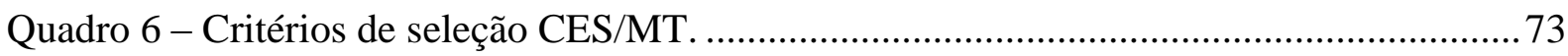

Quadro 7 - Critérios de seleção CES/MS. ........................................................................ 74

Quadro 8 - Resumo esquemático do instrumento de pesquisa - Prestação de Contas. ........... 77

Quadro 9 - Prazos de encaminhamento dos relatórios aos CES. ........................................... 83

Quadro 10 - Categorização do indicador implantação e departamentalização - CES/GO. .....93

Quadro 11 - Categorização do indicador Avaliação das Necessidades - CES/GO..................97

Quadro 12 - Categorização do indicador Liderança - CES/GO............................................ 100

Quadro 13 - Categorização do indicador mobilização de recursos - CES/GO. …................ 103

Quadro 14 - Categorização do indicador implantação e departamentalização - CES/MT. ...110

Quadro 15 - Categorização do indicador avaliação das necessidades da comunidade - CES/MT.

Quadro 16 - Categorização do indicador liderança - CES/MT........................................... 116

Quadro 17 - Categorização do indicador mobilização de recursos - CES/MT. ......................119

Quadro 18 - Categorização do indicador implantação e departamentalização - CES/MS.... 125

Quadro 19 - Categorização do indicador avaliação das necessidades - CES/MS.................. 128

Quadro 20 - Categorização do indicador liderança - CES/MS ............................................. 130

Quadro 21 - Categorização do indicador mobilização de recursos financeiros - CES/MS...134

Quadro 22 - Tendências das variáveis da qualidade dos relatórios de prestações de contas apresentados pelas SES do Centro Oeste.

Quadro 23 - Análise do resultado das tendências de amplitude de participação social e qualidade da informação em Goiás

Quadro 24 - Análise do resultado das tendências de amplitude de participação social e qualidade da informação em Mato Grosso 
Quadro 25 - Análise do resultado das tendências de amplitude de participação social e qualidade da informação em Mato Grosso do Sul........................................................ 177 


\section{LISTA DE ABREVIATURAS E SIGLAS}

AIS

CES

CES/GO

CES/MS

CES/MT

$\mathrm{CF} / 88$

CGU

CMS

CMS/POA

CNS

COAP

$\mathrm{CPC}$

$\mathrm{CSC} / \mathrm{MO}$

IASB

IFAC

INAMPS

IPEA

IPSASB

LC

LDO

LOA

LOS

MDS

MPOG

NOB

OAFT

ONGs

PAS

PDRAE
Ações integradas de saúde

Conselho Estadual de Saúde

Conselho Estadual de Saúde de Goiás

Conselho Estadual de Saúde de Mato Grosso do Sul

Conselho Estadual de Saúde de Mato Grosso

Constituição Federal de 1998

Controladoria Geral da União

Conselho Municipal de Saúde

Conselho Municipal de Saúde de Porto Alegre

Conselho Nacional de Saúde

Contrato Organizativo da Ação Pública de Saúde

Comitê de Pronunciamentos Contábeis

Comissão de Saúde Casabô - Montevidéu

International Accounting Standards Board

International Federation of Accountants

Instituto Nacional de Assistência Médica da Previdência Social

Instituto de Pesquisa Econômica Aplicada

International Public Sector Accounting Standards Board

Lei Complementar

Lei de Diretrizes Orçamentárias

Lei Orçamentária Anual

Leio Orgânica da Saúde

Ministério do Desenvolvimento Social

Ministério do Planejamento Orçamento e Gestão

Normas Operacionais Básicas

Orçamento Federal ao Alcançe de Todos

Organizações Não Governamentais

Programações Anuais de Saúde ou Plano Anual de Saúde

Plano Diretor de Reforma do Aparelho do Estado 
Planejamento Estratégico em Saúde

PLOA

Projeto de Lei Orçamentária Anual

PNS

Plano Nacional de Saúde

PPA

Plano Plurianual

RAG

Relatório Anual de Gestão

SES

Secretaria Estadual de Saúde / Secretaria de Estado de Saúde

$\mathrm{SES} / \mathrm{GO}$

Secretaria Estadual de Saúde de Goiás

SES/MS

Secretaria de Estado de Saúde de Mato Grosso do Sul

SES/MT

Secretaria de Estado de Saúde de Mato Grosso

SFAC

Statement of Financcial Accounting Concepts

SMS

Secretaria Municipal de Saúde

STN

Secretaria do Tesouro Nacional 


\section{SUMÁRIO}

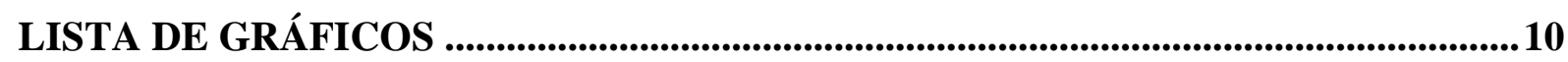

LISTA DE ILUSTRAÇÕES .........................................................................................11

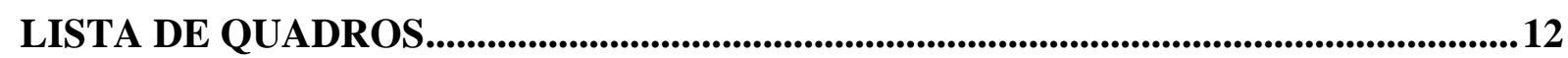

LISTA DE ABREVIATURAS E SIGLAS .......................................................................14

1. CONTEXTUALIZAÇÃO ....................................................................................19

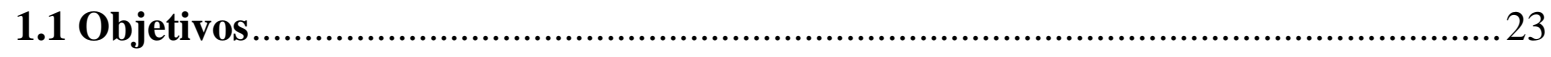

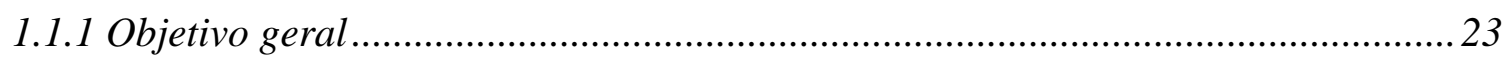

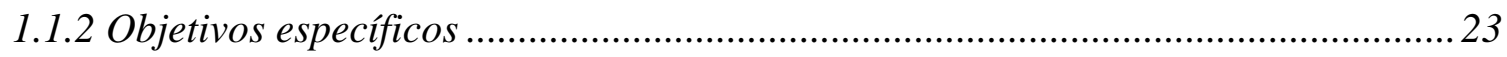

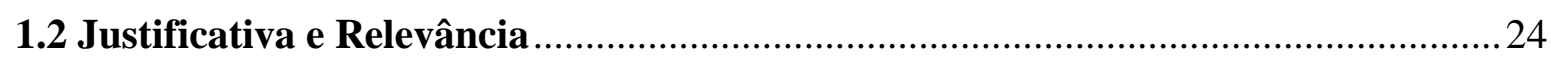

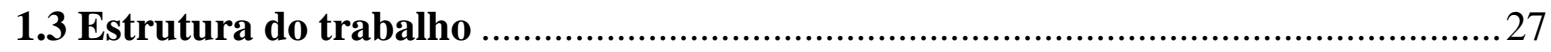

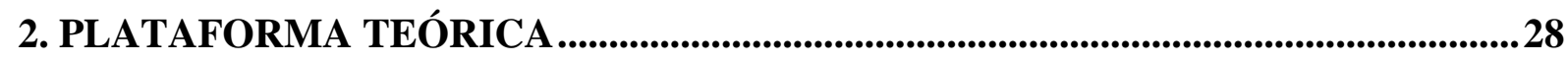

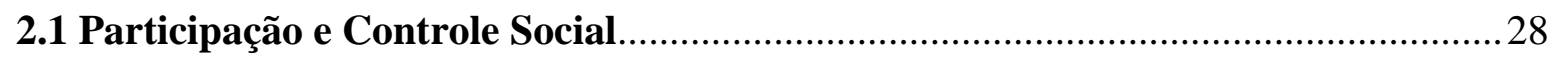

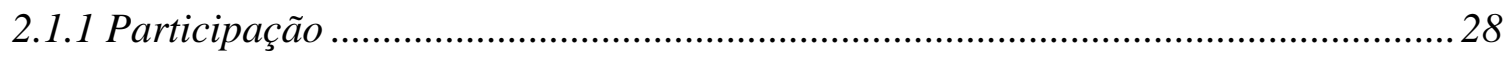

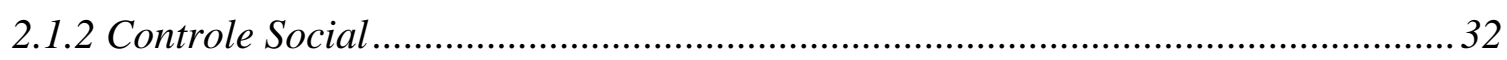

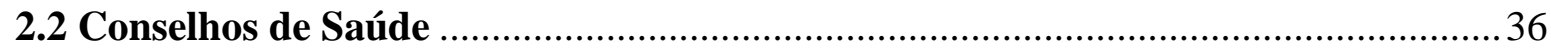

2.2.1 Conselhos de Saúde: da definição à inserção ao contexto brasileiro.........................36

2.3 Prestações de contas e os aspectos qualitativos da informação ……………………... 41

2.3.1 Accountability no Setor Público........................................................................ 41

2.3.2 Prestações de Contas, Conselhos de Saúde, Qualidade da informação e a

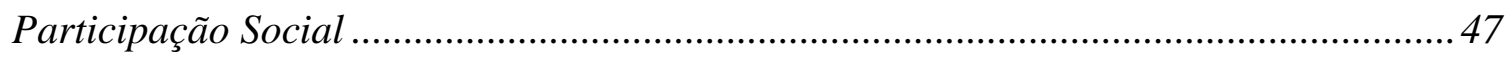

2.3.3 Aspectos Qualitativos da Informação Contábil .......................................................51

2.3.3.1 Características Qualitativas Fundamentais.............................................................. 52

2.3.3.2 Características Qualitativas de Melhoria....................................................................... 56

3. DESENHO METODOLÓGICO ...............................................................................

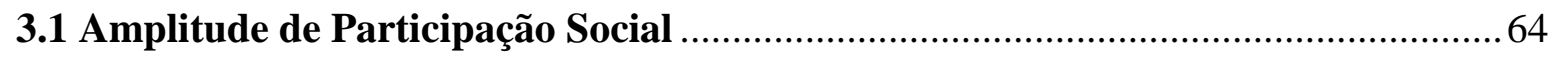

3.1.1 Dimensão da Amplitude de Participação Social .......................................................64

3.1.2 Dimensão Histórica dos Conselhos Estaduais de Saúde ..........................................65

3.1.2.1 Entrevista em profundidade com conselheiro mais antigo do CES .............................. 69

3.1.2.2 Análise das Atas das Plenárias.................................................................................... 72 
3.1.4 Materiais analisados na avaliação da amplitude de participação social dos CES 74

3.2 Prestações de Contas e os Aspectos Qualitativos da Informação ........................... 74

3.2.1 Análise documental como ferramenta de análise dos relatórios ............................ 74

3.2.2 Instrumento de pesquisa - Prestações de Contas e os aspectos qualitativos da

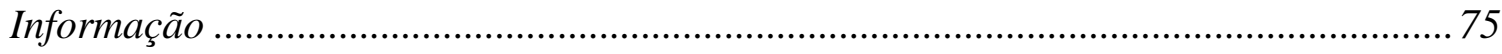

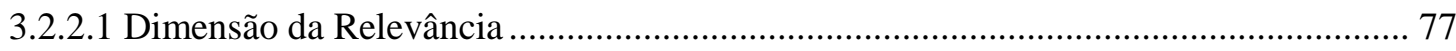

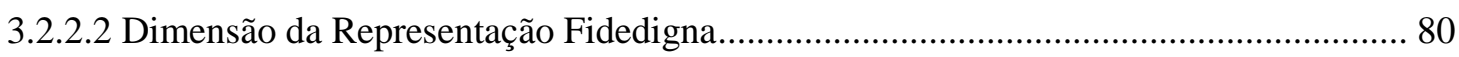

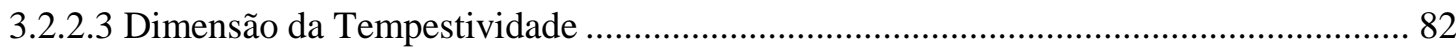

3.2.3 Materiais analisados na avaliação da qualidade dos relatórios das SES .............. 83

3.2.4 Análise e Classificação das Variáveis da Qualidade da Informação ...................... 83

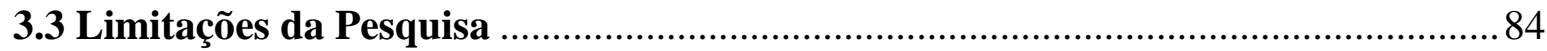

4. ANÁLISE DOS RESULTADOS ..............................................................................86

4.1 Amplitude de Participação da Comunidade nos Conselhos Estaduais de Saúde da

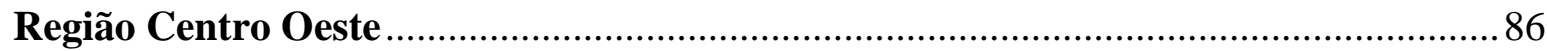

4.1.1 Amplitude de Participação Social da Comunidade no CES/GO.............................. 86

4.1.1.1 Implantação e Departamentalização (Dimensão Histórica) ............................................ 87

4.1.1.2 Tradução das Demandas da Comunidade ...................................................................... 94

4.1.1.2.1 Avaliação das Necessidades da Comunidade............................................................. 94

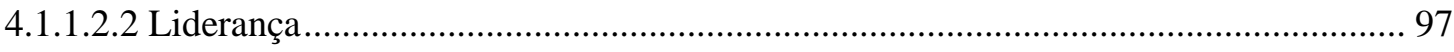

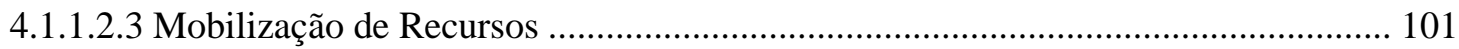

4.1.2 Amplitude de Participação Social da Comunidade no CES/MT ........................... 103

4.1.2.1 Implantação e Departamentalização (Dimensão Histórica) ......................................... 103

4.1.2.2 Tradução das Demandas da Comunidade ..................................................................... 111

4.1.2.2.1 Avaliação das Necessidades da Comunidade........................................................ 111

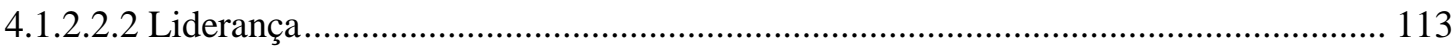

4.1.2.2.3 Mobilização de Recursos ...................................................................................... 116

4.1.3 Amplitude de Participação Social da Comunidade no CES/MS ........................... 119

4.1.3.1 Implantação e Departamentalização (Dimensão Histórica) ........................................... 120

4.1.3.2 Tradução das Demandas da Comunidade ………………………………….............. 126

4.1.3.2.1 Avaliação das Necessidades da Comunidade.......................................................... 126

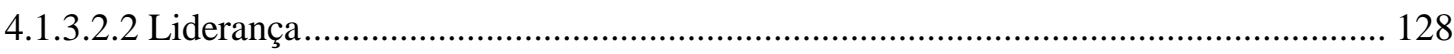


4.1.3.2.3 Mobilização de Recursos

4.1.4 Discussão dos resultados da amplitude de participação nos CES da Região Centro Oeste

4.2 Qualidade da Informação das Prestações de Contas das Secretarias Estaduais de Saúde.

4.2.1 Análise da Dimensão da Relevância nas prestações de contas das Secretarias Estaduais de Saúde.

4.2.1.1 Análise da subdimensão Materialidade nas prestações de contas das Secretarias

Estaduais de Saúde.

4.2.2 Análise da Dimensão da Representação Fidedigna nas prestações de contas das Secretarias Estaduais de Saúde.

4.2.3 Análise da Dimensão da Tempestividade nas prestações de contas das Secretarias Estaduais de Saúde.

4.2.4 Resultados gerais da avaliação da qualidade da informação das prestações de contas das Secretarias Estaduais de Saúde.

4.3Amplitude de Participação Social da Comunidade e a Qualidade das Prestações de Contas das Secretarias de Saúde.

4.3.1 Amplitude da participação social do CES/GO e a Qualidade da Informação das Prestações de Contas da SES/GO... 160

4.3.2 Amplitude da participação social do CES/MT e a Qualidade da Informação das Prestações de Contas da SES/MT ..... 169

4.3.1 Amplitude da participação social do CES/MS e Qualidade da Informação das Prestações de Contas da SES/MS.................................................................................... 176

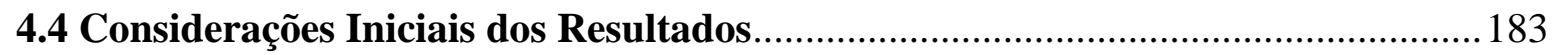

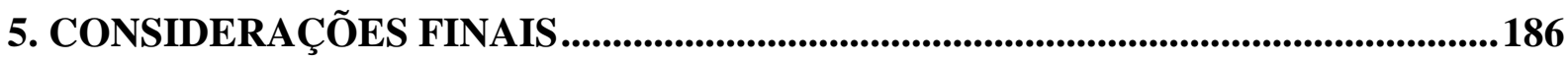

ANEXO A - Roteiro de entrevista do instrumento de Amplitude de Participação Social.....202

ANEXO B - Instrumento de avaliação dos relatórios de prestação de contas e critérios para avaliação do conteúdo avaliado pelas variáveis - Dimensão Materialidade.

ANEXO C - Instrumento de avaliação dos relatórios de prestação de contas e critérios para avaliação do conteúdo avaliado pelas variáveis - Dimensão Relevância

ANEXO D - Instrumento de avaliação dos relatórios de prestação de contas e critérios para avaliação do conteúdo avaliado pelas variáveis - Dimensão Confiabilidade. .205 


\section{CONTEXTUALIZAÇÃO}

A promulgação da Constituição Federal (CF) de 1988 trouxe uma nova concepção para os serviços de Saúde do Brasil, tornando-os universais - possibilitando amparo a todos os cidadãos - e instituindo-os como dever do Estado (SILVA, 1999). Ainda com relação à CF, incisos I e III, do art. 198, cumpre-se destacar que estes implementaram questões como a descentralização e a participação da comunidade, respectivamente. Na esteira dessas evidências, a criação do Sistema Único de Saúde (SUS) veio para dar forma aos preceitos citados e, por consequência, foi balizada nos princípios da universalidade e equidade com o propósito de prover serviços de saúde (COELHO, 2007).

O significado de participação, segundo o Aurélio (2008, p. 672), faz referência a 'ter ponto em comum', 'ser parte' e 'ter ou tomar parte'. Neste sentido, entende-se que a comunidade deve ser parte das discussões a respeito de políticas públicas de saúde como forma de atender ao dispositivo constitucional - inciso III, art. 198. Os indivíduos participantes desse processo têm o intuito de atingir objetivos que estejam alinhados às suas demandas. Além disso, os referidos objetivos podem estar ligados à reforma, à transformação ou à manutenção de uma determinada situação na qual a comunidade local, por exemplo, faça parte (GIOVANELLA, 2008). Para Rifkin (1989) a participação supõe atividades organizadas para aumentar, em determinadas situações sociais, o controle sobre os recursos e sobre as instituições de regulamentação por parte de grupos e movimentos que, em princípio, se consideravam excluídos do referido controle.

Ainda sob o prisma da participação, Fleury e Lobato (2009) consideram que para haver democracia deliberativa é preciso experimentar uma boa dose de amplitude da participação no processo deliberativo. Em face do exposto, a referida amplitude da participação social adentra o cenário do controle social das ações do Estado, pois o envolvimento da população, via representação de conselheiros, nas questões da saúde, pode incentivar a fiscalização e melhoria dos serviços prestados. Portanto, a amplitude de participação social poder ser entendida como um instrumento que pode vir a influenciar no processo deliberativo responsável por auxiliar a condução da saúde.

No entanto, salienta-se que para cumprir a finalidade precípua do Estado - prover serviços de qualidade aos cidadãos, por exemplo no âmbito da saúde - é preciso que existam recursos que proporcionem o cumprimento destas atribuições. Para que seja possível vislumbrar 
a importância dos montantes investidos ${ }^{1}$ nessa e em outras áreas cumpre-se destacar a representatividade dos investimentos em relação ao orçamento total. A referência para esta análise está balizada nos anos de 2013 e 2014, com R \$ 2.250,9 trilhões e 2.467,6 trilhões de orçamento total, respectivamente. Nesse sentido, são apresentados montantes investidos, por exemplo, nas áreas de Agricultura - 10,5 bilhões (2013), 0,46\% do orçamento, 23,6 bilhões (2014), 0,956\% do orçamento; Educação - $\mathrm{R} \$ 71,7$ bilhões (2013), 3,185\% do orçamento, 81,2 bilhões (2014), 3,291\% do orçamento; Trabalho - R\$ 59,7 bilhões (2013), 2,652\% do orçamento, 64,2 bilhões (2014), 2,602\% do orçamento. Já a área de saúde, em comparação às apresentadas, teve a maior destinação de recursos nos dois anos - $\mathrm{R} \$$ 87,7 bilhões (2013), 3,896\% do orçamento, R\$ 92,3 bilhões (2014), 3,740\% do orçamento (MPOG, 2012, 2013).

Por oportuno, vale mencionar que existem percentuais específicos para aplicação de recursos por parte dos Estados e dos Municípios, conforme preceitua a Emenda Constitucional 29/2000. A discussão dessa norma é importante na medida em que se verifica se os recursos aplicados na saúde respeitam os percentuais constitucionais, ou seja, aquilo que deve ser destinado para cada ente da federação. O fato dos recursos aplicados para Goiás, por exemplo, não atingirem o percentual de $12 \%$ indica que os recursos não estão sendo destinados da maneira correta e que provavelmente os montantes aplicados poderão não ser suficientes para o atendimento das demandas de saúde da sociedade.

Logo, a alocação de recursos como esses afeta o cotidiano dos indivíduos que precisam ter acesso ao SUS e, por consequência, deveria se tornar alvo de interesse da população. Por este motivo, é possível entender que o controle da alocação destes recursos precisa do envolvimento da sociedade. A partir do referido envolvimento, avalia-se a necessidade de ambientes (espaços públicos) para promover o controle das ações do Estado. Sob este prisma, o desenho de parte da problemática desta pesquisa começa a tomar forma no sentido de avaliar a tendência da amplitude de participação social nos Conselhos Estaduais de Saúde do Centro Oeste.

É com esse pano de fundo, que a sociedade, sob a forma de organizações sociais, deve promover o controle das ações do Estado de modo que este possa incorporar as demandas e interesses da população, em matéria de políticas públicas de saúde (CORREIA, 2000). Neste

\footnotetext{
${ }^{1}$ De acordo com dados disponibilizados pelo Orçamento Federal ao Alcance de Todos (OAFT), compilado em consonância com os Projetos de Lei Orçamentária Anual - PLOA - de 2013 e 2014, (MPOG, 2012, 2013).
} 
momento, deve existir sinergia entre a amplitude de participação social e controle das ações do governo. De forma complementar, avalia-se que a participação social pode interferir nas ações do gestor da saúde, de modo a promover, dentre outros, maior transparência de suas ações, via relatórios de prestação de contas.

Não por acaso, é possível visualizar um elo entre participação social, controle social, prestação de contas e a gestão da saúde, pois todos estes elementos integram o contexto preceituado na CF/1988, art. 196, "a saúde é direito de todos e dever do Estado". A partir daí os relatórios de contas podem ser vistos como um canal que pode instrumentalizar a participação social no intuito de fiscalizar as ações da saúde para auxiliar e cobrar a gestão com respeito à entrega de serviços de qualidade. Ao buscar uma atuação mais vigilante o cidadão pode contribuir para que o gestor da saúde seja mais transparente e preste contas de seus atos.

Porém, antes de avaliar uma prestação de contas é necessário entender seu significado. O termo prestação deriva do latim praestatio e faz alusão a ato ou efeito de prestar algo a alguém ${ }^{2}$. Já o termo contas ${ }^{3}$ deriva do verbo computare que se refere à possibilidade de elencar números. Porquanto, pode-se avaliar que a formatação de números de maneira coesa e articulada pode prestar "algo" - informações - aos interessados a partir da formatação de um relatório que viabilize o entendimento necessário para processo decisório. Nessa linha, cumpre salientar que os referidos números se traduzem em recursos e tem a finalidade de atender às necessidades da sociedade, quando aplicados, por exemplo, na área de saúde. Logo, a alocação desses recursos precisa ser verificada e atestada visando a qualidade do gasto público.

Sendo assim, para que seja possível fiscalizar a atuação do gestor público torna-se necessária a participação social - representada por conselheiros de saúde - claro, precedida do entendimento das informações contidas em relatórios que auxiliem, de fato, as decisões dos Conselhos Estaduais de Saúde. Dessa forma, as condições da saúde pública poderiam sofrer melhorias e, por consequência, as ações do gestor da saúde. Todavia, para avaliar um relatório dessa natureza é preciso que o mesmo possua a qualidade necessária para esta finalidade - estar revestido dos aspectos qualitativos da informação contábil.

Com efeito, a pesquisa considera as características necessárias para que relatórios de prestação de contas possam ser considerados inteligíveis por seus usuários (BELKAOUI, 2000; GLAUTIER e UNDERDOWN, 2001; HENDRIKSEN e VAN BREDA, 2011). Face aos

\footnotetext{
${ }^{2}$ Disponível em: <http://pt.wiktionary.org/wiki/prestação>. Acesso em: 17/04/2014.

${ }^{3}$ Disponível em: <http://origemdapalavra.com.br/site/palavras/conta/>. Acesso em: 17/04/2014.
} 
elementos até então elencados, constitui-se a segunda parte da problemática deste trabalho relativa à qualidade dos relatórios de prestações contas encaminhados aos Conselhos Estaduais de Saúde pelas Secretarias Estaduais de Saúde da Região Centro Oeste. Portanto, procura-se descrever a qualidade dos relatórios em epígrafe.

Sob esse invólucro, o Ministério de Desenvolvimento Social ${ }^{4}$ (MDS, 2014) considera que a prestação de contas é o elemento que atesta se a aplicação dos recursos que foram repassados por um ente federativo ocorreu de maneira eficiente e dentro do esperado. No entanto, além de tratar dos elementos os quais constituem a expressão, ora enfatizada, é preciso analisar que para avaliar uma prestação de contas é necessário considerar também qual seria o ambiente apropriado para esta tarefa.

Dessa maneira, cabe inserir na discussão as Organizações Sociais, que em virtude de lei específica, possuem um Conselho de Administração. Este é considerado locus ${ }^{5}$ do controle social das políticas públicas a serem executadas (CÂMARA, 2008). Sob este prisma, o Conselho de Saúde - instância que visa promover a participação da sociedade na definição e execução de políticas públicas de saúde ${ }^{6}$ - pode ser considerado como espécie do gênero Conselho de Administração. Adicionalmente, cabe salientar que a partir da criação destes organismos buscase promover maior participação popular na gestão de políticas públicas, em especial, na área de saúde, com vistas a incluir a sociedade, por meio de seus representantes - associações e entidades institucionalizadas (usuários), prestadores de serviço, servidores e gestores - nas decisões da saúde pública.

Os Conselhos de Saúde integram um ambiente em que os atores políticos e a sociedade coadunam a participação social ao processo de elaboração, implementação e posterior monitoramento das políticas públicas. Ademais, é válido ressaltar que esses conselhos são responsáveis pela avaliação das prestações de contas - remetidas pelas Secretarias de Saúde - e que podem proporcionar melhor controle das contas públicas da área. Isto pode dar forma ao controle social, possibilitando, assim, maior desenvolvimento de ações que considerem os anseios da comunidade e, por fim, que possibilitem maior transparência às ações praticadas (LIMA, 2003).

No foco desses aspectos, os relatórios de prestações de contas acabam se tornando

\footnotetext{
${ }^{4}$ Disponível em: <http://www.mds.gov.br/falemds/perguntas-frequentes/assistencia-social/financiamento/convenios-econtratos-de-repasses/prestacao-de-contas-de-convenios>. Acesso em: 30/06/2014.

${ }^{5}$ Segundo dicionário especializado da língua portuguesa o termo é o plural de loci (lugar) do latim e significa lugar.

${ }^{6}$ Conceito trabalhado por Silva (1999).
} 
um canal de comunicação entre governo e sociedade, haja vista que é a partir da avaliação destes que decisões sobre políticas públicas de saúde são tomadas com o objetivo de atender às necessidades da população. Ao estabelecer um canal de comunicação que seja efetivo por meio da participação popular, as instituições públicas e suas autoridades podem ser questionadas e cobradas a partir do momento em que o instrumento de accountability evidencia os atos governamentais por meio das prestações de contas (OLIVEIRA, 2004).

Diante das razões expendidas, o problema desta pesquisa consubstancia-se no seguinte questionamento: a Amplitude da Participação Social dos Conselhos Estaduais de Saúde da Região do Centro Oeste Possibilita Maior Qualidade na Prestação de Contas das Secretarias Estaduais de Saúde desta região? O cerne desta questão se remete à ideia de que a qualidade das informações divulgadas nas prestações de contas pode contribuir, ou seja, possibilitar maior participação social dos conselhos estaduais de saúde. Por consequência, a ocorrência ou não da participação social pode acarretar reflexos, sejam eles positivos ou negativos, para o atendimento às demandas da sociedade em matéria de políticas públicas de saúde.

\subsection{Objetivos}

\subsubsection{Objetivo geral}

Analisar se a amplitude de participação social dos Conselhos Estaduais de Saúde da região do Centro Oeste possibilita maior qualidade da prestação de contas das Secretarias Estaduais de Saúde desta região.

\subsubsection{Objetivos específicos}

- Avaliar a dimensão da amplitude de participação social dos Conselhos Estaduais de Saúde da região Centro Oeste;

- Avaliar a dimensão histórica dos Conselhos Estatuais de Saúde da Região Centro Oeste;

- Descrever a qualidade da informação dos relatórios de prestações de contas das Secretarias Estaduais de Saúde do Centro Oeste; 
- Descrever o ambiente de controle social dos Conselhos Estatuais de Saúde da Região Centro Oeste;

- Discutir a amplitude da participação dos Conselhos Estatuais de Saúde da Região Centro Oeste em face da qualidade dos relatórios de prestações de contas das Secretarias Estaduais de Saúde.

\subsection{Justificativa e Relevância}

A $14^{\text {a }}$ Conferência Nacional de Saúde, realizada em 2012, aprovou uma diretriz, dentre 34, que evidencia a necessidade de ampliar e qualificar os meios para promover a participação social nas políticas de Seguridade Social. Sob este prisma, é possível inserir na referida conjuntura a figura dos Conselhos Estaduais de Saúde (CES), responsáveis pela avaliação das prestações de contas encaminhadas pelas Secretarias Estaduais de Saúde (SES), e interpretá-los como canais de comunicação entre o Estado e a Sociedade.

Não obstante, a descentralização ou municipalização, como tratada por alguns autores (CUNHA, 1994; GAVA, 1992; JOVCHELOVITCH, 1993; SILVA, 1999; CORREIA, 2000), dos serviços de saúde pública tem justamente o intuito de promover uma gestão mais próxima da comunidade. Além disso, salienta-se que o organismo no qual este contexto está inserido - Sistema Único de Saúde (SUS) - tem como um de seus pilares a participação permanente da população. Por conseguinte, o estudo da participação social é importante para que as políticas públicas e o sistema de saúde possam ser mais bem compreendidos (GIOVANELLA, 2008).

Em outra perspectiva, a participação da comunidade exerce uma função de controle social do Estado (GERSCHMAN, 2004). Logo, este controle pode ser praticado por meio do acompanhamento da alocação de recursos públicos nas ações da área de saúde. Desta forma, o veículo para proceder este acompanhamento - neste caso, dentro da esfera estadual, é a prestação de contas encaminhada ao CES. No que tange aos aspectos mencionados, algumas pesquisas foram realizadas com o objetivo de adentrar às abordagens da amplitude de participação e de prestações de contas dentro da área de saúde.

A pesquisa de Silva (1999) buscou analisar a amplitude da participação da comunidade no Conselho Municipal de Saúde de Porto Alegre (CMS/POA), sob o ponto de vista 
de seus conselheiros - por meio de um instrumento baseado nos teóricos Likert (1975), Rifkin et al. (1989) e DEMO (2001). O estudo apontou que a amplitude de participação no conselho tende a ser aberta, isto é, o CMS possui mais iniciativa e possibilita maior avaliação das necessidades da comunidade e, por consequência, maior controle da alocação de recursos.

Grisotti et al. (2010) em sua pesquisa buscaram analisar a efetividade, resolutividade de ações do SUS e a respectiva satisfação de seus usuários - tendo como pano de fundo o Conselho Municipal de Saúde de Florianópolis e o seu respectivo envolvimento com a comunidade. Os resultados evidenciaram compreensões diferentes de saúde entre os indivíduos. Além disso, verificou-se que existia uma distância entre as ações praticadas e aquilo que foi idealizado como estratégia adequada para a saúde local. Com respeito ao conselho de saúde, foram verificadas deficiências na sua forma de se organizar, na sua composição e na sua representatividade - esta última em virtude do papel desempenhado pelos conselheiros face às demandas sociais.

Ainda com relação à amplitude da participação Gonçalves et al. (2010) buscaram examinar a relação entre comunidades consideradas participativas, via conselhos de saúde, e a sua influência nas deliberações, nas cidades de Porto Alegre (Brasil) e Montevidéu (Uruguai). Como resultado o estudo concluiu que a tendência de amplitude de participação do CMS/POA é aberta e a do CSC/MO é restrita. Com relação à primeira constatou-se que estava num estágio participativo mais desenvolvido, ao passo que a segunda em estágio inicial. Os autores consideram que por se tratar de uma organização no estágio de participação ampla (CMS/POA) todos os processos poderiam ocorrer de maneira mais eficiente no conselho.

Por outro lado, algumas pesquisas foram realizadas relacionadas a questão de prestações de contas dentro âmbito de conselhos de saúde. Gonçalves et al. (2010) construíram um instrumento de pesquisa para verificar a utilidade das informações contábeis contidas nas prestações de contas da Secretaria de Saúde do Distrito Federal - sob a ótica de uma ferramenta de auxílio ao exercício das atribuições conferidas do Conselho de Saúde do Distrito Federal. Os resultados mostraram a necessidade de melhoria no conteúdo das informações disponibilizadas nos relatórios, bem como nos objetivos e metas traçados para o exercício subsequente. Dessa forma, as informações teriam maior caráter de utilidade informacional e, por conseguinte, contribuiriam para o exercício de atribuições do Conselho de Saúde.

Já Gonçalves et al. (2011) analisaram o desempenho do Conselho Municipal de 
Saúde de Natal (CMS) por meio de informações de natureza econômico-financeira prestadas pela Secretaria Municipal de Saúde (SMS). Os resultados mostraram que os conselheiros têm um nível baixo de compreensão em relação às informações de ordem econômico-financeiras. Isto ocorre em virtude da divulgação incompleta de informações por parte da SMS. Logo, o CMS fica prejudicado ao tentar construir inferências acerca da devida destinação de recursos.

Rezende (2013) analisou o processo de prestações de contas e o controle social concernentes aos relatórios encaminhados pela SMS de Anápolis ao seu respectivo CMS. Dentre os resultados da pesquisa foi proposta uma resolução para normatizar o processo de prestação de contas, bem como a composição de um manual de prestação de contas - enfatizando a qualidade e a vinculação das informações ao planejamento, com intuito de melhorar a tomada de decisão e exercício do controle social.

Diante dos estudos anteriores, foi possível verificar uma lacuna ainda não trabalhada. Este espaço não preenchido diz respeito a uma possível relação entre a amplitude da participação social e a qualidade informacional dos relatórios de prestações de contas no âmbito dos conselhos de saúde. Sob este enfoque, surge um questionamento quanto ao resultado de uma maior Participação Social dos Conselheiros de Saúde em relação a possibilidade de melhoria da qualidade das prestações de contas.

Por oportuno, destaca-se o caráter de inovação da pesquisa ao trazer um ponto ainda não abordado pela literatura e que pode contribuir para o falseamento de pesquisas futuras dever de uma pesquisa científica (SMITH, 2011) - em outros conselhos do país de modo a verificar a questão em evidência.

Ao considerar a hipótese da amplitude da participação social possibilitar maior qualidade da informação para os relatórios de prestações de contas encaminhadas pelas SES é possível inferir que o controle das ações do Estado pode contribuir para o atendimento mais eficiente das demandas sociais na área de saúde, tendo em vista as melhores condições para acompanhamento e fiscalização dos atos governamentais. Face ao exposto, a avaliação da amplitude de participação e a possibilidade de maior qualidade dos relatórios de prestações de contas se justifica adequada para o objetivo proposto. 


\subsection{Estrutura do trabalho}

A pesquisa está estruturada em cinco seções. A primeira delas faz referência à questão motivadora da pesquisa, sua problemática e seus objetivos. Já a segunda traz os pilares de sustentação para a discussão aqui proposta e a terceira se remete à operacionalização do estudo. A quarta seção tem por finalidade apresentar os resultados relativos a tendência da amplitude de participação dos Conselhos Estaduais de Saúde da Região Centro Oeste. Já a sexta seção objetiva tecer considerações acerca dos resultados encontrados de maneira comparada entre os conselhos. Por fim, são apresentadas a considerações finais acerca da pesquisa realizada. 


\section{PLATAFORMA TEÓRICA}

\subsection{Participação e Controle Social}

Esta seção objetiva elucidar o significado e pontos relacionados à participação social, inclusive no contexto brasileiro, além de seus possíveis desdobramentos como, por exemplo, o controle social das ações do Estado. Esse intento vai ao encontro da inquietação levantada nesta pesquisa - se a amplitude de participação social possibilita maior qualidade na prestação de contas encaminhada aos Conselhos Estaduais de Saúde -, pois por meio de uma avaliação mais presente, criteriosa, e alinhada aos anseios da comunidade é possível que a gestão da saúde pública seja mais efetiva na sua finalidade precípua - com auxílio de prestações de contas adequadas. Nesse sentido, é preciso que a essência do controle social esteja presente em todo esse processo, sustentado pelo catalisador democrático "participação", e possa interferir nas ações do gestor da saúde de modo que se proporcione maior transparência, via prestações de contas, da gestão da saúde.

\subsubsection{Participação}

A etimologia da palavra participação, na perspectiva de Avelar e Cintra (2007), remonta ao século $\mathrm{XV}$, momento no qual foi resgatada da língua latina. $\mathrm{O}$ termo deriva de participatio, participatum e participacionis. Estes termos significam "tomar parte em", estabelecer algum tipo associação entre sentimentos, ações e práticas. No entanto, é preciso considerar quem é a figura do participante. Neste sentido, Demo (2001) afirma que sem o cidadão, considerado como ator principal da conjuntura democrática, não há democracia.

Para Morgan (2001) a participação é o direito que a população tem de participar das decisões que afetam a sua vida rotineiramente e que, além disso, promovem um ambiente democrático para o controle social de instituições. Dessa forma, a linha traçada por Demo (2001) cujo homem é o ator principal do cenário democrático é corroborada. Na perspectiva de Silva (2005, p. 59) "o fenômeno da participação continua sendo um importante fator para o funcionamento da democracia, representando ainda hoje um elemento crucial na tomada de decisões junto às organizações e Estado". 
Ademais, a participação constitui-se em uma relação que envolve a tomada de decisão na qual o indivíduo propõe-se a interagir com o outro, num convívio que democratiza os espaços comuns (públicos) em qualquer âmbito - familiar, cultural, econômico ou político. A participação está focada em prover maior controle do indivíduo sobre as situações que lhe afetam direta ou indiretamente na sociedade a qual vive (ESCOREL; MOREIRA, 2008).

De acordo com Demo (2001) a participação não pode ser considerada como um ato que convoca indivíduos interessados em determinadas causas para discuti-las. Para o autor a participação é uma forma de intervir na realidade que permeia a vida dos próprios indivíduos e que, portanto, deve ser conquistada. Logo, a participação é um exercício democrático e, além disso, um processo o qual tem como desdobramento a construção organizada da emancipação social (DEMO, 2001).

Para Silva (1999) a participação é processo constante de vir-a-ser, onde os grupos podem compartilhar das necessidades por meio do estabelecimento de mecanismos que proporcionem o atendimento às necessidades populares. A autora destaca ainda que este processo busca nortear o interesse coletivo para que o controle social possa, de fato, ser exercido. Ainda nesse contexto, é possível explorar algumas formas de exercer o controle social sobre as ações do Estado, considerando como impulso a participação social conquistada pelo cidadão como cita Demo (2001). Para tanto, verifica-se a necessidade de promover a criação de locais propícios à discussão da partição social enquanto ferramenta para o controle social.

De maneira complementar, Fuks e Perissinotto (2006) afirmam que o fato de espaços participativos estarem à disposição dos indivíduos não é suficiente para a ampliação, de fato, da participação. A partir daí, reitera-se o conceito do ideário participativo ser conquistado constantemente. Seguindo esse pensamento, cumpre-se destacar o processo de vir-a-ser da participação dentro do contexto do brasileiro para, então, continuar a dialogar com literatura no intuito de ensaiar maiores esclarecimentos acerca do termo em questão.

Sob esse invólucro, Lavalle (2011) entende que a participação em solo tupiniquim não foi e ainda não pode ser classificada predominantemente como categoria analítica da teoria democrática deliberativa ${ }^{7}$, pois esta ocorre de forma mais prática - advinda da visão

\footnotetext{
${ }^{7}$ Faria $(2000$, p. 1) afirma que a teoria democrática deliberativa pressupõe o argumento de "que o processo de decisão do governo tem de ser sustentado por meio da deliberação de indivíduos racionais em fóruns amplos de debate e negociação.”. Além disso, a autora afirma que as deliberações resultam de um processo de comunicação em espaços públicos “que antecede e auxilia a própria formação da vontade dos cidadãos.” (FARIA, 2000, p. 1).
} 
emancipatória de camadas populares, também abordada por Demo (2001) - no sentido de nortear a ação coletiva dos atores populares. Ainda segundo a autora, a participação no Brasil emergiu de forma mais enfática na década de 1960, muito em função da ditadura militar - motivo pelo qual surgiram atores sociais pró-democratização com a finalidade de fazer com que a pauta das camadas populares pudesse avançar.

Já num segundo momento o ideário participativo assume novo perfil, agora em virtude da constituinte, transformando o conceito de participação popular em participação cidadã. Em primeira instância, supõe-se que isto ocorreu por conta da semântica de participação ter se tornado algo comum para os atores envolvidos na constituinte, pois as mobilizações da democracia e a progressiva liberalização política sedimentaram o ambiente para tal (LAVALLE, 2011).

Não obstante, Milani (2006) destaca que no início dos anos 1990, em meio a um processo de reforma da administração pública na América Latina e no Brasil, a participação cidadã se constituiu como um dos princípios centrais do processo de deliberação democrática repercutindo em foros regionais e internacionais. Como exemplo da dilatação dos meios e locais para discutir participação, Rojo, Milani e Arturi (2004) argumentam que esta integra a agenda política de organizações como Fórum Social Mundial, Banco Mundial, União Europeia, Nações Unidas, além de outros órgãos. Diante da multiplicidade de atores discutindo participação é preciso assumir a existência de outros contornos e relações que ideário participativo pode assumir.

Por conseguinte, ao explorar um pouco mais o termo participação, em seus contornos, Giacomoni (1994) a conceitua como qualquer ação que possa ser considerada participativa e que seja tratada nas instâncias de interesse coletivo. $O$ autor ainda destaca o elemento político dentro desse campo. Sob esse cenário, entende-se que a participação não se trata apenas de uma questão social, na verdade, trata-se de uma questão também de ordem política (CREMOSE, 2009).

Fuks e Perissinotto (2006), ainda em relação aos referidos contornos participativos, consideram que a intenção depreendida do âmbito da legislação, quando da criação de espaços participativos, tem o objetivo de ampliar a participação e, por consequência, interferir no processo decisório, até mesmo mudando ou construindo uma nova agenda pública. Então, ao tratar do processo decisório, os autores preceituam que este seria resultado perceptível de 
questões sociais e políticas, e teria relações institucionalizadas capazes de interiorizar valores e percepções de atores sociais envolvidos em relações de poder, as quais coadunam aspectos políticos na esfera de um espaço participativo.

Adicionalmente à inserção da questão política, Alves e Viscarra (2006) afirmam que a participação política pode ocorrer de três formas: participação convencional, participação não convencional e a participação comunitária. A primeira ocorre por meios institucionalizados, previamente autorizados ou regulamentados através leis e normas. A segunda representa ações não institucionais, o que contraria regras estabelecidas, podendo ocorrer por meio da obstrução de vias públicas, ocupações de prédios públicos, ou seja, sob a forma de protestos ou movimentos sociais contrários a determinadas questões da gestão política.

A terceira forma ocorre por meio da criação de Organizações Não Governamentais (ONGs) e associações comunitárias. No entanto, destaca-se que para o contexto empregado nesta pesquisa a participação social assume apenas a forma institucional, discutida também por Fuks e Perissinotto (2006), pois para que os movimentos sociais e associações comunitárias tenham voz na gestão da saúde pública é preciso que estejam organizados, isto é, legalmente constituídos, e que constituam um representante - conselheiro - o qual possa fazer parte da estrutura representativa dos Conselhos de Saúde. A partir de então, é possível abrir o canal de comunicação entre Estado e a sociedade. Nesta perspectiva, o controle sobre as ações do governo pode ser interpretado como canal em que a participação cidadã é incorporada ao sistema político (BRESSER PEREIRA, 1999).

Após discutir a participação social, insere-se a questão da amplitude desta para com as questões da saúde. Incialmente, é preciso buscar o seu conceito e aplicá-lo à realidade da saúde pública. O termo amplitude possui alguns significados nos dicionários. Dentre eles se apresentam extensão, magnitude, importância de algo ou potencial de determinada coisa (HOUAISS, 2008). Para o foco desta pesquisa a expressão "amplitude da participação" detém significado relacionado à magnitude, ou seja, o quão participativos são os Conselhos Estaduais de Saúde da região Centro Oeste no cumprimento de suas atribuições legais - na busca pelo controle social.

Sob esse invólucro, Fleury e Lobato (2009, p. 242) consideram que na experiência democrática brasileira, após a promulgação da $\mathrm{CF} / 88$, houve pressão por parte de indivíduos pertencentes a instâncias colegiadas de saúde no sentido de buscar maior participação e 
distribuição de poder das instituições. Nesse sentido os autores argumentam que:

os Conselhos deveriam constituir instâncias nas quais a democracia fosse radicalizada por possibilitar a participação, a inclusão de diversos segmentos populacionais nos processos decisórios e pela natureza de seu caráter deliberativo na formulação e acompanhamento das políticas, o que vários autores chamam de 'democracia deliberativa', na qual a legitimidade da democracia é conferida pela amplitude (e qualificação) da participação no processo deliberativo.

A partir do fragmento de Fleury e Lobato (2009) fica claro que para haver democracia deliberativa é preciso experimentar uma boa dose de amplitude da participação no processo deliberativo. Em face do exposto, a amplitude da participação social adentra o cenário do controle social das ações do Estado, pois o envolvimento da população, via representação de conselheiros, nas questões da saúde, pode incentivar a fiscalização e melhoria dos serviços prestados. Por consequência, na hipótese de participação social mais ativa é possível pensar que a transparência das informações governamentais na área de saúde possa ser incrementada, pois o controle social pode proporcionar isso. Ou seja, a busca da inserção da "amplitude da participação no processo deliberativo" (FLEURY; LOBATO, 2009, p. 242).

\subsubsection{Controle Social}

Segundo Correia (2000) a definição de controle social possui origem nos estudos de sociologia. A autora conceitua controle social como a capacidade que a sociedade tem de interferir na gestão pública de forma a orientar as ações do Estado e os gastos públicos para as necessidades de sua classe. Carvalho (1995) afirma que o controle social é uma expressão a qual está vinculada à relação entre Estado e sociedade, onde cabe a esta promover a vigilância e o controle sobre os atos governamentais. Já Barros (1998) define controle social sobre as ações estatais como a democratização dos processos decisórios que objetivam a construção de cidadania.

O controle social pode ser conceituado como canal institucional de participação na gestão governamental, contando com a presença de indivíduos que representam o coletivo nos processos decisórios, não se tratando de movimentos sociais que existem de forma autônoma para o Estado (CONSTRUCTION, 2003). No Brasil o controle social tomou corpo com o início do processo de democratização vivido na década de 1980. Neste momento a expressão passou a 
ser entendida como forma de controle exercido pela sociedade sobre o Estado. Em termos contemporâneos, é possível citar dois canais institucionais de participação social na saúde, responsáveis por discutir controle social, quais sejam: conferências de saúde e conselhos (CORREIA, 2005).

Para Correia (2000) as conferências de saúde têm como foco avaliar e propor diretrizes para políticas de saúde desenvolvidas pelas três esferas do governo. Dessa forma, é possível pautar a proposição de novas políticas públicas alinhadas às necessidades daqueles que se inserem em um canal participativo aberto por meio de espaços públicos. Seguindo essa ótica, o canal para discutir essas questões perpassa a figura do conselho de saúde - visto pela autora como instância colegiada de caráter permanente e deliberativo, composta de forma paritária entre os representantes da sociedade: usuários, gestores públicos, trabalhadores da saúde, filantrópicos e trabalhadores privados. Com efeito, o objetivo principal dessa instituição participativa tornase a busca pelo controle social (CORREIA, 2000).

Cabe acrescentar, por outro lado, que o controle social não pode ser praticado caso os atores sociais responsáveis por controlar as ações do Estado não tenham acesso a informações que possam influenciar a condução da gestão da saúde. Para contextualizar o acesso às referidas informações no Brasil, destaca-se a lei 12.527/2012, que regula o acesso a informação na administração pública. Em seu art. 5 fica clara a atribuição do Estado no sentido de "garantir o direito de acesso à informação, que será franqueada, mediante procedimentos objetivos e ágeis, de forma transparente, clara e em linguagem de fácil compreensão". O referido artigo aborda questão inerente a parte do mosaico proposto nesta pesquisa: o acesso a informações da gestão da saúde pública, no caso, via prestação de contas para avaliar as ações do gestor da saúde.

Todavia, para considerar se determinada linguagem é transparente, clara e de fácil compreensão avalia-se quais seriam as características necessárias para cumprir tal finalidade. Dentro dessa perspectiva, e com objetivo de responder ao questionamento posto, cumpre salientar os aspectos qualitativos da informação contábil como instrumentos de avaliação da qualidade dos relatórios de prestação de contas das ações governamentais de saúde. A justificativa se dá em virtude da qualidade da informação estar alinhada ao tripé elencado no art. 5 da lei de acesso à informação - transparência, clareza e fácil compreensão.

Nazário, Silva e Rover (2012) consideram que a qualidade da informação é prérequisito essencial para que haja efetiva transferência de conhecimento e informações - vistos 
aqui como insumos para transparência - entre os indivíduos que atuam em diversas áreas do conhecimento. No tocante ao foco deste trabalho, é possível traçar, então, um paralelo entre os aspectos qualitativos da informação contábil, transparência das ações do Estado e participação, no sentido de promover meios para o fortalecimento do controle social.

A esse respeito, a Controladoria Geral da União (CGU, 2009, p. 27), em sua cartilha para o controle social, considera que "a participação ativa do cidadão no controle social pressupõe a transparência das ações governamentais". Portanto, revestir o controle social de maior participação - incentivando maior amplitude participativa - pode gerar mais transparência. Além disso, o mesmo órgão julga ser necessário disponibilizar para todo cidadão brasileiro acesso as informações da gestão pública, no sentido de privilegiar a relação governo e sociedade, a partir do prisma da transparência e responsabilidade social.

Segundo a própria CGU, a transparência da gestão pública depende da publicação de informações; de espaços públicos de participação que procurem solucionar problemas e da construção de canais de comunicação entre sociedade civil e governante. No que tange a aplicação dos recursos públicos e sua transparência, é preciso informar como se gasta o dinheiro e, mais do que isso, prestar contas dos seus atos (CGU, 2009).

Em síntese, essas proposições perpassam a questão de relatórios de prestação de contas como ferramenta de controle social e transparência. Logo, o acesso à informação, com objetivo de promover maior transparência, pode ser visto como abertura de espaço para uma segunda fase, ligada ao nível de utilização das informações - fato condicionado à amplitude da participação social. Nesse caso, supõe-se que maior participação precedida de acesso à informação pode promover maior transparência às ações de saúde pública. Sob essa ótica, Silva et al. (2007) argumentam que para fortalecer o controle social na esfera da saúde, via participação, é preciso que os sujeitos políticos envolvidos detenham conhecimento - fase posterior ao acesso a informação - efetivo do SUS, demais legislações, realidade epidemiológica, assistência social, parte financeira, política entre outras.

No entanto, para adquirir conhecimento e, mais do que isso, praticá-lo em uma instituição participativa é preciso que as informações cheguem de forma adequada aos responsáveis pelo processo decisório em matéria de saúde pública. A partir de então, abre-se espaço para discussões que efetivamente possam influenciar no atendimento às demandas da sociedade. A esse respeito, Chauí (1993) afirma que esses sujeitos políticos participantes do 
meio social se envolvem nas referidas discussões de acordo com a proporção e o volume de informações recebidas. Porquanto, o autor aponta a publicização das informações como fator importante para este pleito, além das condições favoráveis para que estas sejam, de fato, aproveitadas pelo sujeito político no sentido de intervir como produtor de saber nas áreas em que está presente (CHAUÍ, 1993).

Não por acaso, o envolvimento dos sujeitos no controle social, abordado por Chauí (1993), além de ser influenciado pela proporção e volume de informações recebidas, está, também, relacionado a outros fatores que podem condicionar a amplitude da participação social exercida por estes. Afinal, a busca pela participação citada anteriormente, por Demo (2001) e Silva (1999), sobre processo constante de vir-a-ser, pode influenciar o fortalecimento do controle das ações do Estado tendo como base diferentes facetas do conhecimento da área de saúde.

Essas facetas podem estar relacionadas a experiências vividas pelos sujeitos nas áreas de saúde, ou em outras áreas do conhecimento que possam ter implicações em matéria de saúde - trânsito, segurança pública, parte ambiental entre outros -, a conhecimentos ligados à gestão da saúde e demais aspectos (SILVA et al., 2007; SARRETA; BERTANI, 2010). Ao considerar os fatores elencados é possível visualizar a necessidade de aplicação desse conhecimento para dar resolutividade às necessidades da sociedade. Isto pode representar o adensamento das práticas de controle social e, por consequência, maior participação social da comunidade. Diante do exposto, retoma-se o conceito da amplitude como medida de uma onda de participação que oscila em virtude do maior ou menor envolvimento participativo dos sujeitos políticos, com vistas a instrumentalizar ferramentas e novos caminhos para o controle social.

Oportunamente e como base na proposta desta pesquisa frisa-se que, além dos conhecimentos citados por Silva et al. (2007), os responsáveis - conselheiros de saúde - pelo controle social utilizem este aprendizado no intuito de ampliar a sua participação no controle das ações do gestor público da saúde por meio, também, da análise das prestações de contas encaminhadas pelas Secretarias Estaduais de Saúde. Dessa forma, espera-se que uma maior participação, precedida do conhecimento necessário, possibilite maior qualidade nas prestações de contas e, por consequência, na transparência da gestão da saúde pública. 


\subsection{Conselhos de Saúde}

A seção tem por finalidade definir conselho de saúde e ambientá-lo no contexto brasileiro, além de mostrar quais são as necessidades e demais questões para que a participação possa acontecer, operacionalizando, assim, o controle social. Adicionalmente, objetiva-se mostrar quais são as suas atribuições legais para cumprir tal finalidade. Dessa forma, é possível adensar o conhecimento sobre essas instituições participativas para então proporcionar melhor compreensão acerca do nível de amplitude de participação social, eventualmente, possibilitar maior qualidade às prestações de contas recebidas pelo CES.

\subsubsection{Conselhos de Saúde: da definição à inserção ao contexto brasileiro}

A etimologia da palavra deriva do latim consilium e está alinhada ao conceito de deliberação, opinião, parecer, juízo; assembleia de pessoas que deliberam sobre certos assuntos ou grupo de pessoas que estejam encarregadas de administrar (GONÇALVES et al., 2011). Ademais, segundo Gohn (2001) a expressão conselho deriva de um conceito já utilizado desde a época dos clãs visigodos e se remete à ideia de instrumento que promove a participação popular. A autora ainda faz menção aos conselhos que ganharam notoriedade na história como a Comuna de Paris, Conselhos operários de Turim, Conselhos do Sovietes Russos dentre outros.

Em perspectivas contemporâneas, a literatura organizacional norte-americana considera que o board (conselho administrativo) possui a função de deliberar sobre as questões a ele atribuídas (CÂMARA, 2008). Para Gonçalves et al. (2011, p. 3) a definição do conceito de conselho perpassa o significado de alguns termos, quais sejam: i) "board - diretoria; junta; banca; conselho administrativo", ii) "Board of directors - conselho de administração", iii) "Board of trustees - administradores", iv) “Accountability - responsabilidade sujeita à prestação de contas".

Câmara (2008) afirma que o Conselho de Administração, previsto na lei das Organizações Sociais, é considerado como locus de controle social para a execução de políticas públicas. A autora considera ainda que o conselho de administração é a instância máxima para deliberação, representando o poder público sob a forma de organizações da sociedade civil, exercendo controle sobre políticas organizacionais e fiscalizando a implementação das políticas públicas. 
Já para Telles (1999) os conselhos podem ser vistos como "arenas públicas" que podem tornar evidentes questões relacionadas aos conflitos de demandas sociais e promover visibilidade à essas questões. Dessa forma, segundo o autor os conflitos de demandas sociais podem permitir a construção de parâmetros públicos responsáveis por nortear a criação de políticas que afetem a vida de todos na área de saúde. Na perspectiva de Giovanella (2008) instâncias participativas podem ser consideradas como espaços nos quais os indivíduos podem atuar em conjunto com objetivo de dar forma aos seus anseios sociais. Portanto, essas instâncias reúnem atores políticos para definir estratégias, submetidas a um processo de escolha, e para direcionar sua atuação no sentido de promover o processo participativo (GIOVANELLA, 2008).

Por oportuno, cumpre-se destacar a visão de Avritzer (2002) com respeito à proposição de um modelo o qual sintetize as condições necessárias para que um espaço público participativo - aqui considerado como conselho de saúde - possa cumprir a sua finalidade. Então, o autor considera as relações entre a sociedade, sistema político e o âmbito público (governo), pois estas entram como alternativa para um modelo que se concentra na competição existente entre as elites ${ }^{8}$ - um dos fatores responsáveis por, muitas vezes, minimizar a participação social. A questão principal proposta pelo modelo foca ampliar o espaço participativo para prover abordagem democrática mais consistente. A partir desta perspectiva Avritzer (2002, p. 143) avalia que o ideário do modelo deve ser norteado por quatro pontos principais, quais sejam:

\footnotetext{
i) Primeiramente, devem existir espaços públicos participativos que atuem em nível público por meio da formação de mecanismos de deliberação face-a-face, cuja liberdade de expressão e de associação estejam presentes. Estes mecanismos são destinados a abordar elementos específicos na cultura dominante através da identificação de problemáticas sociais no sentido de transformá-las em uma agenda política;

ii) Movimentos sociais e associações voluntárias precisam enfrentar questões controversas através da proposição e introdução de práticas alternativas em nível público - avessas às formas clientelistas de reivindicar bens públicos. O produto dessas práticas precisa ser compatível com os direitos humanos;
}

iii) Os espaços públicos participativos mantêm um ambiente de complexidade

\footnotetext{
${ }^{8}$ Para Avritzer (2002) existem governos representados por elites e estes estão em sentido oposto à luta contra o fortalecimento de mecanismos contraditórios de democracia, ou seja, trata-se de um misto de relações que podem enfraquecer a autonomia organizacional da sociedade e, por consequência, da democracia. Para justificar essa questão, o autor afirma que dois dos motivos concretos para crer em tal fato são o estrangulamento de recursos para determinadas demandas da sociedade e a publicização de seletiva do Estado (somente o que lhe interessa). Estas são questões perfeitamente aplicáveis à realidade dos conselhos de saúde e podem diminuir a participação social em virtude dos obstáculos apresentados.
} 
administrativa e por conta disso não podem ser vistos como instâncias voltadas apenas para profissionais técnicos tomarem decisões. Sob essa ótica, é preciso encontrar equilíbrio entre seus diferenciados representantes no intuito de monitorar a implementação das suas decisões - a partir de uma visão mais ampla e menos técnica do cenário;

iv) As deliberações desses espaços públicos devem estar vinculadas à busca de formas institucionais capazes de abordar e solucionar as questões levantadas pelo interesse coletivo.

Após delinear definições e condições necessárias para o ambiente dos conselhos de saúde, insere-se a sua contextualização em solo tupiniquim. $\mathrm{O}$ fato de a $\mathrm{CF} / 88$ ter definido a saúde como direito de todos e dever do Estado fez com que o Sistema Único de Saúde fosse criado sob o prisma do acesso universal. Com o advento deste organismo foi um pouco mais trabalhada a noção de controle social e participação da população. Neste sentido, a ideia de Conselhos de Saúde floresceu da estrutura legal do SUS e passou a ser pensada como instância que seria responsável por integrar a comunidade no processo de gestão da saúde local (COELHO, 2007).

No entanto, Arretche e Rodriguez (1999) destacam elementos precedentes à constituinte como a bandeira levantada pelo movimento sanitarista em relação à descentralização da política nacional de saúde, no final da década de 1970, e a corrente para a universalização do acesso aos serviços de saúde. Os autores ainda afirmam que esses elementos vieram a se materializar como princípio de gestão a partir de dois propulsores, a saber: $8^{\mathrm{a}}$ Conferencia de Nacional de Saúde e a própria CF/88. Ao buscar motivações para contextualizar esse momento, Arretche e Rodriguez (1999) citam a implementação de Ações Integradas em Saúde (AIS) ocorrida na primeira metade da década de 1980 - como passo importante para a pulverização de recursos e ações para a saúde de modo a esboçar a descentralização.

Todavia, a efetividade dessa medida ocorreu, de fato, na criação e implementação do Sistema Unificado e Descentralizado de Saúde (SUDS) momento no qual os estados assumiram a função das superintendências regionais do antigo Instituto Nacional de Assistência Médica da Previdência Social (Inamps). Com efeito, as secretarias estaduais de saúde começaram a cuidar da gestão da rede do Inamps e de uma parcela da rede conveniada privada (ARRETCHE; RODRIGUEZ, 1999).

Em 1990 houve um processo de negociação para institucionalizar progressivamente a descentralização. Então, foram instituídas a Lei Orgânica da Saúde (LOS), em 1990, e as 
Normas Operacionais Básicas (NOB) ${ }^{9}$, em 1993, no sentido de operacionalizar uma gestão pluriinstitucional a partir da criação de conselhos nas esferas federal, estadual e municipal. Além disso, cumpre-se destacar a criação de comissões bipartite e tripartite para negociação entre os níveis de governo como a consolidação deste processo. Ademais, os municípios foram definidos como gestor específico dos serviços de saúde, além de serem classificados, para fins de inserção no SUS, de acordo com sua condição de gestão do sistema: incipiente, parcial e semipleno dado o seu grau de complexidade (BRAGA JUNIOR, 1998; ARRETCHE; RODRIGUEZ, 1999).

De acordo com Junior (1998) o SUS foi regulamentado e aperfeiçoado pelas leis 8.080/90, 8.142/90 e, de forma mais enfática, pela NOB 01/93. A lei 8.080/90 estabeleceu critérios para nortear as ações e serviços de saúde com base em princípios como universalidade, igualdade, integralidade, participação popular e descentralização político- administrativa, além de dispor sobre as formas de organização do SUS (BRAGA JUNIOR, 1998). A lei 8.142/90 reeditou o artigo que versava sobre a participação da comunidade - antes vetado pela lei 8.080/90 - e instituiu a figura dos conselhos municipais, estaduais e federal, bem como a realização de conferências nacionais de saúde. Ademais, promoveu maior autonomia a estas instâncias lhes concedendo o direito de instituir, via regimento interno, suas normas e atribuições (MOREIRA; ESCOREL, 2005).

Entretanto, mesmo após a edição das referidas leis a 9a Conferência de Nacional de Saúde, realizada em 1993, foram verificados resultados modestos para aquilo que havia sido preconizado, tornando, portanto, o processo de descentralização incipiente (BRAGA JUNIOR, 1998). O autor justifica o ocorrido com base no descompromisso dos gestores e na falta de entendimento acerca dos diferentes estágios dos estados e municípios país afora, o que gerou entraves no processo. Por conseguinte, o mesmo cita que ao possuir informações acerca do panorama ora abordado, o Ministério da Saúde elaborou a NOB 01/93 a qual regulamentou a entrada de estados e municípios no SUS, além definir instrumentos operacionais e procedimentos para gestão deste.

Ainda no âmbito do Brasil, o Plano Diretor de Reforma do Aparelho do Estado (PDRAE, 1995) trouxe mudanças para promover a reforma da Administração Pública. Dentre elas, o Projeto de Organizações Sociais foi utilizado como instrumento de gestão privada da

\footnotetext{
${ }^{9}$ Especificamente, as Leis no 8.080/90; 8.142/90 e a NOB n ${ }^{\circ} 01 / 93$.
} 
execução de políticas públicas. Neste sentido, o controle social se dá por meio da participação da sociedade em organizações sociais, vistas como instâncias participativas - via representantes da comunidade legalmente constituídos e eleitos pela população. Com esse contexto de pano de fundo, os elementos preceituados pela $8^{\text {a }}$ Conferência Nacional de Saúde, realizada em 1986, coadunam as proposições discutidas anteriormente por Arretche e Rodriguez (1999). Para Escorel e Moreira (2008, p. 998) o produto desta conferência:

[...] preconizou a criação em nível municipal, estadual e regional, de conselhos de saúde compostos por representantes eleitos pela comunidade (usuários e prestadores de serviço) que permitissem a participação plena da sociedade no planejamento, execução e fiscalização dos programas de saúde (grifo nosso).

Desta forma, é preciso haver regulamentação pertinente para atender o ideário de conselho apresentado na $8^{\mathrm{a}}$ conferência. Em linhas gerais, cabe salientar que os conselhos de saúde devem deliberar sobre as diretrizes da saúde para proporcionar o devido estabelecimento de prioridades relacionadas às ações e serviços públicos de competência do gestor e destinados à população, dentre outras atividades. A partir daí, a característica de maior participação pode ser buscada com maior efetividade. Ao definir conselhos e destacar um apanhado conjuntural destes, faz-se necessário, então, discutir suas atribuições - as quais necessariamente perpassam normas mais específicas. Sob esses aspectos, cita-se a resolução do Conselho Nacional de Saúde n $333 / 2003$ que regulamentou as principais diretrizes para criação, estruturação e reformulação dos Conselhos de Saúde - recentemente alterada pela 453/2012.

A resolução de 2012 trouxe inovações ${ }^{10}$, sendo possível destacar das nove mais importantes, o fato de o conselho passar a ter poder de decidir sobre seu orçamento e não mais apenas gerenciar verbas. Outro ponto, é a responsabilização dos conselheiros pelo exercício de suas atribuições. Ademais, esta resolução inseriu mudanças realizadas pela Lei Complementar 141/2012 e o Decreto n ${ }^{\circ}$ 7.508/2011 - normas responsáveis por regulamentar a LOS - no tocante às atribuições dos Conselhos: avaliar o funcionamento e a organização do SUS, examinar indícios de irregularidades, responder a consultas relativas a ações e serviços de saúde e apresentar recursos acerca das deliberações do Conselho, nas devidas instâncias.

\footnotetext{
10 Principais inovações: atribuições, mandato, renovação de entidades, responsabilidades, participação da sociedade, orçamento, quórum, competências e banco de dados. Para maiores informações ver conteúdo disponibilizado pelo CNS em <http://conselho.saude.gov.br/ultimas_noticias/2012/12_jun_resolucao453.html >.
} 
A Lei Complementar $n^{\circ}$ 141, de 13 de janeiro de 2012, incrementou as atribuições existentes para o controle social na legislação que rege o SUS. Esta lei contém dispositivos com atribuições específicas aos Conselhos de Saúde referentes ao papel exercido pelo conselheiro no processo de fiscalização, avaliação e controle das despesas com ações e serviços públicos de saúde na União, Estados, Distrito Federal e Municípios. Além disso, estabelece regras importantes acerca da periodicidade de entrega dos relatórios de prestações de contas e das despesas as quais podem ser consideradas com ações e serviços públicos de saúde - Art. $3^{\circ}$.

Já o decreto 7.508/2011 estabeleceu definições como o que seria Região de Saúde, Portas de entrada - serviços de atendimento básico, Comissões Intergestores, Mapa da Saúde, instituiu o Contrato Organizativo da Ação Pública de Saúde (COAP) dentre outras questões. Adicionalmente, regulamentou a organização do SUS de forma hierarquizada e regionalizada e tipificou, além da configuração do Planejamento de Saúde, a assistência à Saúde. Após a montagem do mosaico da saúde - focado em Conselhos desta área - verifica-se o alcance participativo que estas instâncias possuem, bem como a capacidade de inserção em questões que promovam o controle das ações dos gestores.

Eis porque os normativos citados devem ser considerados como mecanismos responsáveis pela busca do controle social e, mais do que isso, como elementos condutores que podem ser incrementados pelo nível de amplitude de participação social praticado. Por oportuno, destaca-se o fato da $13^{\text {a }}$ Conferência Nacional de Saúde, dentro de suas propostas, ter enfatizado a apresentação das prestações de contas por meio de divulgação ampla - via eletrônica e impressa - aos Conselhos e à população de forma que, então, o controle social pudesse ser assegurado. Nesse contexto, verifica-se relação entre as atribuições do Conselho, amplitude de participação social e as prestações de contas, considerando inclusive a qualidade destas, como eventual ferramenta para a participação e, por conseguinte, para o controle social.

\subsection{Prestações de contas e os aspectos qualitativos da informação}

\subsubsection{Accountability no Setor Público}

De acordo com Campos (1990) para que se possa discutir a questão da accountability no setor público é preciso que antes os cidadãos se organizem de modo a fiscalizar as ações governamentais. Além disso, a autora considera que para ocorrer tal organização é 
preciso também que o cidadão seja consciente de seus direitos. Portanto, para que haja meios para inserção da accountability - atuação dos cidadãos no sentido de buscar e incentivar canais para controle das ações governamentais -, a população deve ser considerada como tutora das ações do Estado e não tutelada (CAMPOS, 1990).

Ainda na concepção da autora, a tentativa de conceituar claramente o termo accountability é uma tarefa difícil, mas a ideia por ela extraída se remete, na sua visão, à abordagem de Frederich Mosher ${ }^{11}$ (1968), e diz respeito à responsabilidade objetiva ou obrigação de responder por algo. Sob esta perspectiva, Campos (1990, p. 3) considera que existe um "elo entre accountability e a necessidade de proteger os cidadãos da má conduta burocrática". Logo, caso haja este tipo de conduta, a responsabilidade pela sua prática deve ser invocada e punida.

Pinho e Sacramento (2009) após levantamento realizado em dicionários da língua inglesa, buscaram compilar uma síntese do termo. Os autores consideram que a accountability é a obrigação e a respectiva responsabilização dos indivíduos que ocupam cargos e tem o dever de prestar contas - atendendo a leis e normativos. Eles destacam, ainda, a possibilidade de sanções para o não cumprimento dos padrões estabelecidos. Oliveira (2004) afirma que a expressão accountability pode ser entendida como um processo onde a responsabilização objetiva e subjetiva das instituições e de seus respectivos responsáveis pode ocorrer. Adicionalmente, o autor considera que esta responsabilização ocorre em virtude do controle exercido pela organização da sociedade, sob a forma de espaços públicos democráticos.

Já Ruediger (2002) afirma que a transparência é um elemento basilar para a construção de um ambiente democrático. Pinho (2008) reitera este pensamento ao considerar que a accountability, de maneira aproximativa, pode ser visualizada como a transparência, como o engajamento dos indivíduos governantes no sentido de prestar contas, bem como a responsabilização pelos seus próprios atos. A partir de então, já é possível vislumbrar que accountability envolve "conceito com significado e amplitudes plurais" (AFONSO, 2000, p. 58), portanto, considerada como multifacetada.

Dentro dessa ótica, Schedler (1999) afirma que a interpretação do conceito de accountability traz consigo dimensões e significados diferentes. Existem duas interpretações

\footnotetext{
${ }^{11}$ Mosher, F. Democracy and the pub/ic service. New York, Oxford University, 1968. p.7.
} 
básicas para que se possa entender accountability na esfera política e governamental. A primeira delas se refere à capacidade que os governos têm de dar respostas, entendidas aqui como explicações de seus atos, às suas obrigações oficiais previamente instituídas - answerability. Já a segunda faz alusão às agências de accountability (accountability agencies) e a sua capacidade de enforcement para sancionar aqueles que porventura violarem os deveres públicos (SCHEDLER, 1999). Nesse sentido, Carneiro (2004, p. 3) afirma que "a noção de accountability, é basicamente, bidimensional: envolve capacidade de resposta e capacidade de punição (answerability e enforcement)".

Por outro lado, O’Donnell (2006) traz a definição de accountability horizontal que se refere a práticas de fiscalização exercidas pelos cidadãos e pela sociedade civil, com o objetivo de constituir formas de controle sobre os agentes públicos. Além disso, o autor menciona que accountability vertical ocorre por meio de organismos institucionalizados que se controlam e se fiscalizam mutuamente, sob a perspectiva de checks and balances (freios e contrapesos). Outrossim, destaca-se a atuação de agências governamentais que tem por finalidade monitorar e fiscalizar o poder público e seus respectivos órgãos estatais (O’DONNELL, 2006; REZENDE, 2013).

Para Pacheco (2004), a concepção de accountability pode ser compreendida a partir da esfera de accountability societal. Cabe destacar que esta perspectiva também tem origem na dicotomia entre Estado e sociedade civil. Contudo, a abordagem fornece a concepção de que o controle social sobre as ações governamentais constitui caráter de singularidade no que diz respeito ao atendimento das demandas da sociedade (CARNEIRO, 2004). Sob esta ótica, Pacheco (2004, p. 4) considera que "accountability vista como demanda social faz referência às exigências da opinião pública quanto à transparência e eficiência no uso de recursos públicos”.

No que se refere à relação mencionada por Pacheco (2004), Pinho (2008) em seu trabalho sobre a investigação de portais eletrônicos do governo no Brasil aborda a questão da accountability e da participação popular no sentido de avaliar se estas ferramentas - portais estão contribuindo para o aprofundamento da democracia, por meio da transparência. Dentro dessa linha, o autor enfatiza um dos conceitos de governo eletrônico, o government-to- 
citizen $^{12}$ como elemento central da discussão.

Todavia, a aplicação desse conceito - visto ainda como restrito pelo autor - pode ir mais além do que tão somente disponibilizar um serviço; quando proporciona "manifestação de maior transparência, o que significa informações de mais qualidade e conteúdo, referentes a processos políticos" (PINHO, 2008, p. 474). Diante disso, salienta-se o envolvimento entre accountability, transparência e os aspectos qualitativos da informação como elementos que podem iniciar a construção de ambiente propício à participação social para controle das ações do Estado, ou seja, de resposta ao cidadão.

Face às ponderações expostas, cumpre-se distinguir a perspectiva societal das abordagens de accountability horizontal e vertical, pois para Smulovitz e Peruzzotti (2000) estas abordagens podem ser consideradas um pouco precárias em determinados aspectos. Os autores consideram com exemplo disto a questão de que as experiências de delegação de poderes e a excessiva discricionariedade acabam por prejudicar mecanismos de coesão existentes entre os poderes. Desta forma, o exercício do accountability horizontal acaba sendo fragilizado. Já com relação à abordagem vertical entende-se que os mecanismos tradicionais de controle por meio de eleições demonstram debilidades que dificultam o atendimento às demandas sociais (SMULOVITZ; PERUZZOTTI, 2000).

Após uma pequena incursão acerca dos fatos favoráveis da abordagem societal destaca-se a necessidade de instâncias que promovam a participação da comunidade em aspectos de políticas públicas e que, assim, possam mitigar problemas entre o Estado e sociedade. Bresser Pereira (1996) afirma que o reconhecimento de um espaço público não estatal - considerado por Oliveira (2001) como ambiente que estabelece relação com Estado por meio do controle social - poderia fazer um papel de intermediação, com o objetivo de promover o surgimento de uma forma de controle social direta ou com parceira. $\mathrm{O}$ fato é que se utilizar destes organismos não estatais faz com que as atividades governamentais sejam controladas por meio da sociedade. Logo, cabe enfatizar que o controle do Estado é verificado e complementado pelo controle social, na perspectiva aqui trabalhada, sob a forma de conselhos de administração integrados pela sociedade - na figura de representantes (BRESSER PEREIRA, 1996).

\footnotetext{
12 Para Joia e Cavalcante Neto (2004) o ente governamental é o agente que disponibiliza um produto ou serviço à sociedade. Já o cidadão responsável por adquirir este produto ou serviço.
} 
A participação social, considerando os conselhos de saúde como pano de fundo, pode promover o controle público por meio da accountability, com vistas a incentivar maior transparência e adequação às necessidades de saúde locais (OLIVEIRA, 2004; REZENDE; 2013). Dentro desse contexto, a abordagem societal se mostra adequada ao objetivo proposto pela concepção de controle social na área de saúde, em especial aquela que deve ser realizada por meio dos relatórios de prestação de contas elaborados pelos entes governamentais.

Miguel (2005) aceita o argumento de que a abordagem societal é importante e deve ser discutida. No entanto, o autor discorda sobre a sua tipificação como dimensão alternativa em relação a accountability horizontal e vertical - sob o argumento de que esta não possuiria tal status, pois seria exercida por meios de comunicação, ONGs e associações, motivo pelo qual não teria a mesma representatividade das outras abordagens. Com efeito, ao seguir a linha de Miguel (2005) a abordagem societal não seria adequada aos conselhos de saúde. Mesmo os próprios defensores da accountability societal, Peruzzotti e Smulovitz (2000), manifestam dúvida em relação à sua aplicabilidade para conselhos.

Apesar disso, faz-se mister considerar que a abordagem societal é aplicável aos conselhos de saúde, justamente pelo fato da própria legislação promover a participação de diferentes segmentos da sociedade. Dentre eles é possível apontar movimentos sociais, associações e as próprias ONGs, como, por exemplo, a pastoral da criança, movimentos sociais LGBT, movimento Negro. Logo, existe espaço para essas nas instituições participativas (conselhos). Portanto, a abordagem societal pode ser utilizada para este contexto, pois carrega legitimidade participativa de movimentos e ONGs legalmente constituídos e inseridos na estrutura dos conselhos de saúde.

Já com respeito a um modelo de accountability, Afonso (2000) aponta três pilares estruturantes, quais sejam: avaliação, prestação de contas e responsabilização. Sob este prisma, entende-se que primeiro é preciso prestar contas para que a parti daí as ações governamentais possam ser avaliadas. Como abordam Pinho (2008) e CGU (2009) o ato de informar o cidadão pode ocorrer também por portais eletrônicos de transparência. Entretanto, para o foco deste trabalho a prestação de contas assume maior importância para subsidiar a avaliação da saúde pública por parte dos conselheiros de saúde. Não obstante, a responsabilização, também, preconizada pela accountability, no SUS, pode ocorrer por meio da não aprovação das contas dos gestores de saúde - fato decido no pleno dos conselhos de saúde. 
Ademais, Afonso (2000) ao subdividir accountability na dimensão de prestação de contas (answerability) e de responsabilização (reponsabilization) elenca aspectos concernentes a cada uma. A primeira delas está alinhada a ideia de fornecer informações, dar justificativas, elaborar e publicar relatórios de avaliação das contas. Já a responsabilização, além da imputação de responsabilidades ou imposição de sanção negativa - entendida, neste caso, também com reprovação das contas anuais -, pode encontrar outras formas legitimas de responsabilização (AFONSO, 2000). As recomendações repassadas e as interpelações de agentes públicos de saúde realizadas pelos conselhos de saúde também podem ser enquadradas como formas legítimas de responsabilização.

De modo acertado, Miguel (2005) discute em sua pesquisa as democracias eleitorais e seus respectivos dilemas na representação política. Mesmo com a existência de problemas nessa relação, o autor afirma que a accountability é elemento importante para proporcionar vínculo entre representantes e representados. Sobre os dilemas da representação política nas democracias eleitorais o autor menciona que o referido ambiente de entraves ${ }^{13}$ tem gerado propostas inovadoras, geralmente com os seguintes objetivos: i) ampliação da representatividade do corpo decisório no sentido de tornar os governantes mais próximos dos governados; ii) ampliação da pluralidade de indivíduos, perspectivas; ampliação da força política de grupos considerados minorias; e iv) ampliação da rotatividade dos cargos decisórios, de modo que se impeça a manutenção de uma elite política no poder.

Oportunamente, nota-se que os objetivos mencionados por Miguel (2005) estão perfeitamente alinhados ao ideário dos conselhos de saúde. O primeiro e o segundo objetivos podem ser vistos dentro dos conselhos sob a perspectiva da pluralidade de segmentos que os compões (usuários, trabalhadores, governo e prestadores de serviços) e sob maior proximidade que os conselheiros podem ter da sociedade, pois integram diferentes grupos desta. Já o terceiro pode ser enfatizado, principalmente, pelo segmento de usuários haja vista a inserção de associações, entidades comunitárias e movimentos sociais como, por exemplo, associações de pessoas portadoras de deficiências, do movimento negro, de queimados dentre outros conforme preconiza a resolução 453/2012, do CNS, na organização dos conselhos de saúde,

\footnotetext{
${ }^{13}$ Para Miguel (2005, p. 25) “a capacidade de supervisão dos constituintes sobre seus representantes é reduzida, devido a fatores que incluem a complexidade das questões públicas, o fraco incentivo à qualificação política e o controle sobre a agenda". Dilemas dessa natureza acabam por impactar aspetos ligados a accountability.
} 
inciso III.

Por fim, o objetivo que trata da rotatividade dos cargos pode ser verificado de acordo com regimentos internos dos conselhos, os quais indicam o prazo do mandato e, seguindo orientação da resolução 453/2012, abordam a necessidade de renovação ${ }^{14}$ de entidades participantes. Portanto, a accountability permeia o ambiente dos conselhos de saúde e abre espaço para a prática do controle social - caso haja participação social para proporcionála.

Oliveira (2001) faz um pequeno apanhado do ambiente o qual coaduna a accountability, conselhos de saúde, controle social, qualidade da informação e transparência. Para o autor a atuação dos conselhos comunitários de fiscalização do SUS possui o objetivo de efetivar o controle social da administração pública, por meio também de iniciativas de transparência vinculadas à prestação de contas direta à sociedade. Entretanto, o autor considera que a abundância de informações, por si só, não promove, de fato, o controle social. Para tanto, julga ser necessário oferecer "informações qualificadas que lhe permitam responder, com pouco trabalho, as questões de grande interesse para ele tanto no papel de usuário quanto no de controlador da administração" (Oliveira, 2001, p. 147).

Não obstante, destaca-se que a accountability não é mera substituição de controles por uma fiscalização mais próxima da comunidade. Primeiro, é preciso visualizá-la como a integração de todos os meios - considerados formais ou não - juntamente com a “superexposição da administração, que passa a exibir as contas ao exame de fiscais não mais uma única vez por ano e em linguagem hermeticamente técnica [...] mas por meio de demonstrativos capazes de ampliar cada vez mais o número de controladores" (Oliveira, 2001, p. 146).

2.3.2 Prestações de Contas, Conselhos de Saúde, Qualidade da informação e a Participação Social

A operacionalização do controle social perpassa a questão da accountability. De acordo com Pacheco (2004, p.4) esta é "entendida como a obrigação permanente de prestar

\footnotetext{
${ }^{14}$ Resolução 453/2012, Organização dos conselhos de saúde, inciso V - "Recomenda-se que, a cada eleição, os segmentos de representações de usuários, trabalhadores e prestadores de serviços, ao seu critério, promovam a renovação de, no mínimo, $30 \%$ de suas entidades representativas".
} 
contas sobre o uso de recursos públicos, os resultados alcançados, e os critérios de decisão utilizados". Consoante a esta perspectiva, existem normativos que abordam questões ligadas à prestação de contas do recurso público empregado no atendimento às necessidades da sociedade.

Neste sentido, a Lei Federal $n^{\circ} 8.689 / 93$, em seu art. 12, determina que o gestor do Sistema Único de Saúde nas esferas municipal, estadual e federal preste contas ao Conselho de Saúde de forma trimestral. Indo mais além, a Resolução nº. 333/2003, emitida pelo Conselho Nacional de Saúde, na sua quarta diretriz, inciso X, versa sobre a questão do conteúdo a ser destacado nas prestações de contas, qual seja: andamento da agenda de saúde pactuada; relatório de gestão; montante, fonte e forma de aplicação dos recursos aplicados; auditorias iniciadas e concluídas no período; oferta e produção de serviços na rede assistencial. Ademais, cumpre-se destacar a alteração de periodicidade de entrega das prestações de contas, agora quadrimestralmente, recepcionada pela resolução do CNS, 453/2012 - quarta diretriz, inciso X.

De forma complementar, a edição da LC n ${ }^{\circ}$ 141/2012, no seu art. 34, define que a prestação de contas, prevista no art. 37, conterá demonstrativo das despesas com saúde integrante do Relatório Resumido da Execução Orçamentária, a fim de subsidiar a emissão do parecer prévio, conforme trata o art. 56 da Lei Complementar $n^{\circ}$ 101, de 4 de maio de 2000. Ademais, a LC 141/2012 estabelece que os conselhos devem avaliar a gestão do SUS, a partir de então, quadrimestralmente e emitir parecer conclusivo sobre o cumprimento dos dispositivos da lei complementar quando da apreciação das contas anuais encaminhadas pelo respectivo gestor federal, estadual, distrital ou municipal.

A avaliação das prestações de contas é um mecanismo importante para o exercício das atribuições dos conselheiros em virtude do controle e acompanhamento das ações praticadas pelo gestor de saúde (GONÇALVES et al., 2010; REZENDE, 2013). Entretanto, Silva et al., (2007) apontam que tornar essa informação inteligível, ou seja, acessível, para os indivíduos no caso desta pesquisa, conselheiros, os quais também podem se utilizar o SUS de forma universal - figura como um grande desafio. Em função do controle e acompanhamento citados é importante existir a participação do usuário envolvido nas questões de saúde - representado pela figura dos conselheiros -, pois a partir dela pode-se, eventualmente, verificar melhorias na atuação dos gestores locais.

Com efeito, o fato de simplesmente divulgar as informações não atende ao propósito do controle social, pois é preciso apresentar a informação em uma linguagem adequada, 
possibilitando, assim, que o usuário possa depreender o que está sendo executado por parte do governo (SILVA et al., 2007). Por este motivo, e para que o usuário possa aplicar seu conhecimento em benefício da saúde pública, retoma-se o discutido anteriormente com respeito às características qualitativas da informação contábil como instrumento de avaliação dos relatórios de prestações de contas.

Ao seguir essa linha de pensamento, Vasconcelos e Viana (2002) acrescentam que a qualidade da informação apresentada nos relatórios financeiros é importante para a tomada de decisão. Para o retrato proposto neste tópico, a respeito de prestação de contas, não é diferente. Sendo assim, a qualidade da informação contábil aplicada às prestações de contas pode permitir que os conselheiros de saúde profiram suas decisões no pleno tomando como referência informações mais acuradas. Na esteira desta proposição, entende-se que quanto mais os relatórios estiverem revestidos de qualidade da informação maior será a condição para o processo decisório.

Malta et al. (2007) confirmam a afirmação anterior argumentando que se as informações necessárias forem transmitidas aos gestores - no caso conselheiros - o processo de tomada de decisão melhorará, desde que estas sejam adequadas, evitando falhas e negligenciamento das informações. De maneira lógica, espera-se que a partir de decisões mais embasadas as decisões sejam mais assertivas em relação às demandas da comunidade.

Ainda com relação aos aspectos qualitativos, Strong et al. (1997) afirmam que informações com qualidade inferior podem gerar impactos significativos para área social e de negócios. Na visão de Huang et al. (1999) várias organizações já sentiram os efeitos adversos que informações com qualidade inferior podem causar às decisões. Então, justifica-se que na hipótese dos aspectos qualitativos estarem presentes nos relatórios de prestações de contas, a análise e a compreensibilidade destes - por parte dos conselheiros de saúde - pode ser incrementada de maneira benéfica no cumprimento da finalidade do Conselho de Saúde.

Todavia, há que se destacar a necessidade de participação social para que tanto as avaliações de prestações de contas quanto a emissão de resoluções em benefício da comunidade possam acontecer. Congruente a esse aspecto, Regoso et al. (2005) consideram como importante a participação do cidadão nas decisões que são tomadas a respeito dos serviços prestados à sociedade. No caso da saúde, a participação social pode ser considerada como catalisador do controle social, principalmente se for precedida do conhecimento necessário dos conselheiros de 
saúde; do acesso à informação de maneira clara, transparente e com linguagem de fácil compreensão como cita a CGU (2009).

Não por acaso, o comportamento da amplitude da participação social - conforme aborda o tópico 2.1.1 - na área de saúde está, também, mutuamente relacionada ${ }^{15}$ ao controle social, transparência e a qualidade da informação. A partir daí, é possível presumir que uma maior participação possibilite maior qualidade, bem como mais qualidade possibilite melhores condições para os conselheiros fiscalizarem a gestão da saúde, portanto, podendo ser mais participativos neste aspecto. Dessa forma, após a discussão, dentro dos tópicos 2.1 e 2.2, de pontos concernentes a participação (SILVA, 1999; DEMO, 2001; MORGAN, 2001; AVELAR; CINTRA, 2004; SILVA, 2005; ALVES; VISCARRA, 2006; FUKS e PERISSINOTTO, 2006; MILANI, 2006; LAVALLE, 2011), controle social (CHAUÍ, 1993; CARVALHO, 1995, BARROS, 1998; CORREA, 2000; CONSTRUCION, 2003; CORREIA, 2005, SILVA et al. , 2007; SARRETA; BERTANI, 2010; CGU, 2009; NAZÁRIO, SILVA; ROVER, 2012); e conselhos (BRAGA JUNIOR, 1998; TELLES, 1999; ARRETCHE; RODRIGUEZ, 1999; GOHN, 2001; AVRITZER,2002; CÂMARA, 2003; MOREIRA; ESCOREL, 2005; COELHO, 2007; GIOVANELLA, 2008; GONÇALVES et al. ., 2011); buscou-se demonstrar o ambiente no qual estas instâncias participativas estão inseridas para, então, adentrar nos aspectos concernentes à prestação de contas - no âmbito da accountability - e às características qualitativas da informação contábil.

Por oportuno, compete ressaltar a lacuna existente na literatura sobre estudos que relacionem a amplitude da participação social e sua possibilidade de ocasionar maior qualidade aos relatórios de prestações de contas. Diante disso, a discussão, ora proposta, destacou separadamente os elementos que dão suporte a construção da problemática desta pesquisa para, a partir de então, formulá-la. Dessa forma, é possível visualizar a amplitude da participação social - assumindo que os usuários possuam conhecimento da área de saúde para entender as contas prestadas e suas características - como fator que pode incrementar a qualidade das prestações de contas, pois é razoável supor que quanto mais participativo for o Conselho de Saúde melhor será o acompanhamento da saúde e, por conseguinte, os relatórios recebidos das

\footnotetext{
${ }^{15}$ Entende-se as que as características elencadas precisam estar presentes no mesmo ambiente para que possa haver, por exemplo, condição favorável para um Conselho de Saúde. Todavia, obviamente o nível em que essas características estão presentes não é o mesmo. Isso pode ocorrer em função justamente do nível de participação alcançado em cada conselho.
} 
Secretárias Estaduais de Saúde. É com esse pano de fundo que se vislumbra a possibilidade de maior vigilância, por parte do cidadão, sobre as ações dos gestores da saúde, fato que pode motivá-lo a prestar contas dos seus atos em prol da saúde pública. Vale lembrar que a discussão da transparência também está alinhada à questão do controle social e da própria participação, como abordado no tópico 2.1.2.

\subsubsection{Aspectos Qualitativos da Informação Contábil}

As características qualitativas da informação são aspectos importantes para que os usuários possam compreender as informações contidas em relatórios, demonstrações e, no caso em questão, as prestações de contas da saúde. Além disso, cabe enfatizar que não basta apenas apresentar informações, é preciso fomentar a geração de informações úteis - de forma a mitigar aquelas que em nada contribuam para a tomada de decisão, pois estas podem, eventualmente, até prejudicá-la. É com esta visão que se considera a necessidade das informações estarem revestidas de qualidade (CAMPELO, 2012).

De acordo com o Financial Accounting Standards Board (FASB, 1980), por meio do Statement of Financial Accounting Concepts (SFAC) $\mathrm{n}^{\circ} 2$, Qualitative Characteristics of Accounting Information, as características qualitativas representam os insumos que constituem informação contábil útil para seus usuários. No entanto, o mesmo organismo considera que existe uma restrição geral destas características, pois ao avaliar a relação de custo/benefício de algumas delas verifica-se um custo superior à produção de benefícios que podem ser gerados em virtude da sua elaboração.

A definição das características qualitativas, por parte de alguns organismos, não necessariamente segue a mesma ótica ao afirmar quais são as mais importantes. O FASB (1980) - SFAC $\mathrm{n}^{\circ} 2$ - considera as seguintes características, quais sejam: compreensibilidade, relevância - que depende do valor preditivo, do valor como feedback e da oportunidade da informação - confiabilidade e sua respectiva verificabilidade, a fidelidade de representação, a neutralidade da informação e a comparabilidade. Por fim, considera a materialidade da informação contábil como um limite para reconhecê-la.

O International Accounting Standards Board (IASB, 1998), por meio do Framework for the Preparation of Financial Statement, elencou as seguintes características: 
compreensibilidade, confiabilidade - revestida pela representação fiel - primazia da essência sobre a forma, neutralidade, prudência e integralidade da informação; relevância - considerando o valor preditivo - o valor como feedback e a materialidade da informação contábil, e, por fim, a comparabilidade.

Já o IFAC (2013) mesmo baseado nas características elencadas pelo IASB, anteriormente, considera quatro características como as mais importantes, a saber: compreensibilidade, relevância - incluindo a materialidade com característica intrínseca -, confiabilidade e comparabilidade. O CPC 00 (R1) ao elaborar a estrutura conceitual para divulgação e elaboração dos relatórios contábil-financeiros elenca as características qualitativas de forma diferenciada. Neste sentido, a entidade as separa em dois blocos, a saber:

i) características qualitativas fundamentais: relevância e representação fidedigna consideradas as mais críticas;

ii) características qualitativas de melhoria: comparabilidade, verificabilidade, tempestividade e compreensibilidade - consideradas menos críticas, porém bastante desejadas.

Ainda com relação ao CPC 00 (R1) vale destacar que a característica antes denominada pelos organismos contábeis como confiabilidade passa a ser representação fidedigna. Não obstante, lançou-se mão também da característica qualitativa prudência, ancorada no aspecto de representação fidedigna, sob o argumento de que esta seria inconsistente com a neutralidade. Por outro lado, cumpre salientar o fato da característica qualitativa materialidade, em consonância com IFAC (2013), estar dentro da relevância.

A justificativa para essa questão pode ser dada pelo CPC 00 (R1) (2013, p. 17) quando este afirma que "a materialidade é um aspecto de relevância específico da entidade baseado na natureza ou na magnitude, ou em ambos, dos itens para os quais a informação está relacionada no contexto do relatório contábil-financeiro de uma entidade”. Logo, a omissão das informações contidas nos indicadores e eventuais distorções podem influenciar nas decisões motivando, assim, a sua como consideração como material.

\subsubsection{Características Qualitativas Fundamentais}

Antes mesmo da definição das características qualitativas da informação contábil 
mencionadas e tipificadas pelos organismos contábeis supramencionados, as discussões para elaboração de normas perpassam aspectos ligados à teoria contábil, afinal para transformá-las em matéria contábil (normas) é preciso sempre considerar uma série de fatores, conceitos e situações - muitas vezes até dinâmicas - caracterizando, também, a necessidade de eventuais adequações. A visão do CPC, na sua estrutura conceitual, demonstra este panorama quando faz alterações nas questões relacionadas às características qualitativas da informação.

No caso de verificar qual é o revestimento qualitativo que relatórios contábeis ou até mesmo prestações de contas, precisam ter, alguns autores empregam suas próprias proposições, à luz da teoria da contabilidade, no tocante às características mais importantes. Hendriksen e Van Breda (2011) e Glautier e Underdown (2001) consideram que os principais aspectos qualitativos da informação necessários para que os usuários possam compreender as informações contidas nos relatórios e, por consequência, tomarem a melhores decisões possíveis, são a materialidade, a relevância e a confiabilidade.

Por oportuno, e ressaltando discussão anterior sobre a reformulação realizada pelo CPC 00 (R1), buscam-se os conceitos teóricos relativos às características qualitativas para depois compilá-los na forma preconizada pelo Comitê: características fundamentais e de melhoria, além da sua respectiva organização. Sendo assim, a materialidade, na perspectiva de Glautier Underdown (2001), pode ser considerada como característica indispensável à informação para esta assumir caráter de utilidade. Hendriksen e Van Breda (2011) afirmam que no momento de decidir divulgar ou não determinada informação algumas características precisam ser verificadas para auxiliar neste processo, são elas: i) dados quantitativos; ii) o grau de itemização dos dados quantitativos, iii) relações especiais entre a entidade e indivíduos ou grupos específicos, afetando os direitos e interesses dos outros indivíduos ou grupos e iv) planos e expectativas da administração.

Então, parte-se da ideia de um olhar avaliativo mais próximo e focado em características como essas para apreciar as prestações de contas recebidas pelo CES, no sentido de realizar análise para dizer o que é pertinente e o que não é dentro dos relatórios. Em outra perspectiva, Bonízio (2001) afirma que além da informação conter itens considerados relevantes pelo usuário, também podem conter informações desnecessárias, que não trazem contribuição para as decisões e que, eventualmente, podem até prejudica-las. No caso dos Conselhos de Saúde, informações desnecessárias dentro das prestações de contas podem atrasar a sua apreciação ou até mesmo confundir os conselheiros no exercício de suas atribuições 
deliberativas.

Ademais, em relação à materialidade destaca-se o fato desta ser intrínseca à relevância. A justificativa para essa questão pode ser dada pelo CPC 00 (R1) (2010, p. 17) quando este afirma que "a materialidade é um aspecto de relevância específico da entidade baseado na natureza ou na magnitude, ou em ambos, os itens para os quais a informação está relacionada no contexto do relatório contábil-financeiro de uma entidade”.

Cabe acrescentar, então, a dimensão da relevância como elemento atrelado a aspectos que fazem com que a informação seja útil em determinado momento e no seguinte não mais, ou seja, relevante para um e não para o outro (ALVES, 2003). O primeiro deles se refere à importância do valor preditivo das informações pelo fato deste fomentar as predições de eventos futuros com base nas informações do passado. O segundo aspecto faz alusão ao valor confirmativo - informações a respeito do resultado de uma decisão tomada anteriormente. Este indicador pode balizar decisões futuras. Neste caso, a predição e a confirmação podem ser consideradas ferramentas importantes para a gestão da saúde, pois uma prestação de contas que forneça subsídios para predição acaba por auxiliar o controle e confirmação daquilo que se julga adequado para sua gestão.

Por fim, o terceiro - oportunidade - considera que uma informação deve estar disponível no momento em que o usuário precisa do seu auxílio para tomar uma decisão (HENDRIKSEN e VAN BREDA, 2011). Logo, caso isto não ocorra, a informação perde a sua materialidade e, consequentemente, o usuário perde a oportunidade de tomar a melhor decisão possível. Todavia, pela nova estrutura conceitual abordada pelo CPC a abordagem da relevância não faz menção ao aspecto da oportunidade. Logo, entende-se como mais razoável inseri-la como uma característica qualitativa de melhoria, mais especificamente como tempestividade.

A dimensão da confiabilidade ${ }^{16}$ - na visão do IASB (1998) - considera que uma informação confiável é aquela que não possui erros materiais e que representa fielmente o que se propõe a representar. É preciso considerar, também, que não deve haver escolhas baseadas na conveniência dos gestores da informação. A omissão de determinadas informações pode ter implicações diretas na qualidade das informações prestadas nos relatórios (GLAUTIER e UNDERDOWN, 2001). Na esfera das prestações de contas da saúde a omissão de informações

\footnotetext{
${ }^{16}$ Considerada pelo CPC 00 (R1) como representação fidedigna.
} 
pode ter implicações diretas no processo deliberativo de Conselho de Saúde e, por consequência, no atendimento de determinadas demandas da comunidade.

Dessa forma, para que a informação possa ser considerada confiável, Glautier e Underdown (2001) tipificaram as características necessárias para o referido intento, a saber: conteúdo, valor descritível e mensurável, neutralidade, precisão e prudência. A primeira estabelece que a informação deve ser fidedigna às transações e eventos ocorridos dentro da organização e, além disso, estar em consonância com os aspectos econômicos da mesma. A segunda estabelece que uma informação deve ser quantificável e possibilitar a realização de projeções de eventos futuros.

A neutralidade revela o caráter de imparcialidade dos gestores, ou seja, não se pode escolher determinadas informações por conveniência. A precisão está relacionada ao fato das informações não serem omitidas sob pena de estas causarem uma falsa impressão ou viés por parte dos usuários (GLAUTIER e UNDERDOWN, 2001). Por fim, e ainda segundo os autores, a prudência está alinhada ao estabelecimento de estimativas para ocorrência de eventos futuros.

Contudo, ao analisar a estrutura conceitual do CPC a característica prudência (conservadorismo) foi retirada do escopo de representação fidedigna sob o argumento de que seria inconsistente em relação a neutralidade. Como justificativa o CPC 00 (R1) (2013, p. 3) menciona que "subavaliações de ativos e superavaliações de passivos [...] com consequentes registros de desempenhos posteriores inflados, são incompatíveis com a informação que pretende ser neutra".

A análise das características qualitativas fundamentais, à luz da teoria contábil e alinhada à estrutura conceitual do $\mathrm{CPC}$, permite a construção de um esqueleto qualitativo que possa dar subsídios à avaliação de relatórios, no caso prestações de contas da saúde, quando moldadas e interpretadas em face das peculiaridades do setor. Um exemplo é verificar o que seria valor preditivo em uma prestação de contas encaminhada ao CES, bem como as outras características. A figura 1 delineia a organização das características qualitativas fundamentais e seus indicadores de forma que num segundo momento serão adequadas à realidade da saúde. 


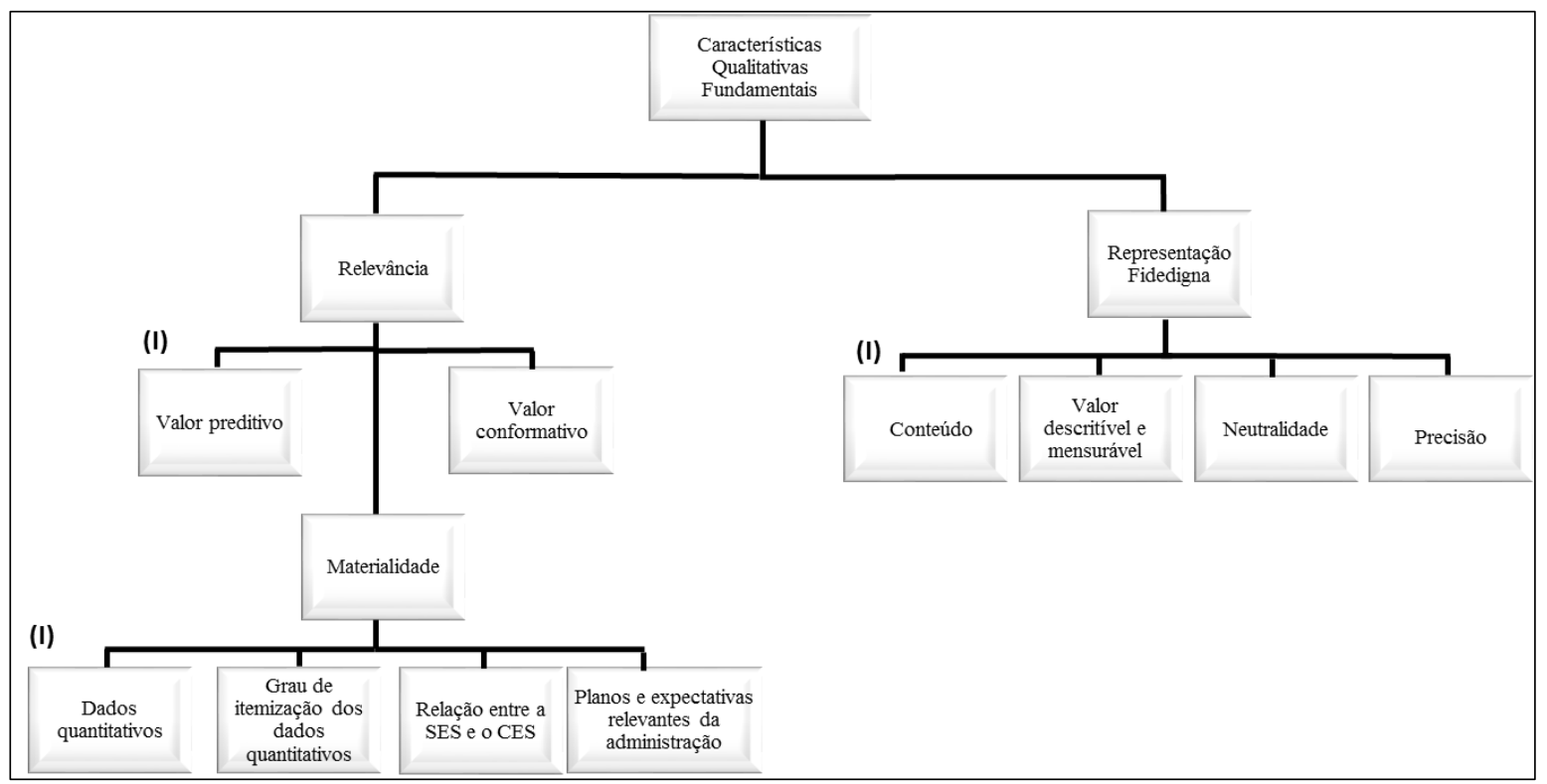

(I) - Indicadores.

Figura 1 - Característica Qualitativas Fundamentais.

Fonte: Elaboração própria.

\subsubsection{Características Qualitativas de Melhoria}

O SFAC $n^{\circ} 2$ ao classificar as características da informação como qualidades secundárias destaca a comparabilidade como informação útil e detentora de dois atributos: uniformidade e consistência. A norma define que a comparabilidade ocorre quando a utilidade de uma informação pode ser ampliada em virtude de sua apresentação permitir comparação com outras entidades ou até mesmo a própria entidade ao longo do tempo. Para Fuji e Slomski (2003) a comparabilidade incrementa a qualidade da informação em virtude de possibilitar justamente as comparações levantadas pelo $\mathrm{FASB}^{17}$. O ganho gerado segundo os autores tem por finalidade melhorar e embasar as predições e decisões financeiras.

Adicionalmente, o IASB (1998) menciona a possibilidade de identificar tendências a partir da comparação entre empresas e da própria entidade. Além disso, reitera, de forma implícita, a questão da consistência na mensuração de transações e eventos. Adicionalmente, o organismo afirma que para possibilitar a comparação é preciso também a presença de outra caraterística, no caso, a menção às políticas empregadas na elaboração dos demonstrativos

\footnotetext{
${ }^{17}$ De acordo com Fuji e Slomski (2003, p. 36) a comparação do FASB se refere à "qualidade da informação que permite identificar semelhanças e diferenças entre dois conjuntos de fenômenos: uniformidade, consistência".
} 
contábeis, pois qualquer alteração nestas pode causar efeitos adversos modificando, eventualmente, o conjunto de demonstrações e demais relatórios. Diante disso, o impacto de eventuais alterações nas políticas empregadas, caso haja, precisa ser abordado nos relatórios para o contexto desta pesquisa, as prestações de contas.

Na perspectiva do CPC 00 (R1) a comparabilidade assume praticamente os mesmos contornos abordados pelos organismos anteriores ao mencionar duas características que a auxiliam: consistência - empregando os mesmos métodos para os mesmos itens - e a uniformidade para que as coisas sejam iguais proporcionando, portanto, a comparação. Por oportuno, vale destacar a afirmação do Comitê ao supor que um bom de grau de comparabilidade possivelmente é alcançado por conta da satisfação das características qualitativas fundamentais. Isto reitera a posição de complementariedade das características qualitativas da informação em relação aos relatórios de prestações de contas da saúde.

O entendimento do FASB (1980) acerca da característica compreensibilidade é de que esta auxilia o usuário a entender as informações contábeis. Porém, vale ressaltar, ainda segundo a entidade, o fato dessa característica requisitar um nível mínimo de conhecimento para utilizar a informação nas decisões. Saudagaran (2009) classifica dois tipos de usuários: hábil e inábil. O autor reitera o pensamento de que a compreensão de relatórios contábeis está embasada no conhecimento de seus usuários considerado hábeis - capazes de compreender as informações.

No entanto, para a realidade dos Conselhos de Saúde a preocupação com entendimento da informação contida na prestação de contas - principalmente ao abordar questões contábeis e financeiras - se mostra controversa pelo fato da multiplicidade de segmentos dos conselheiros que compõe essas instituições participativas, a saber: usuários do SUS, trabalhadores da saúde, gestores e prestadores de serviços. Ocorre que esta diversidade não necessariamente implica em conhecimentos prévios por parte dos responsáveis pelo processo decisório no CES.

Por conseguinte, este panorama dicotômico incita apontamento interessante na medida em que se busca qualidade informacional na elaboração das prestações de contas, haja vista a necessidade de uma linguagem mais acessível para tornar a informação compreensível aos usuários leigos que manuseiam as informações contidas nos relatórios. Dessa forma, lidar com essas questões no sentido de prover maior compreensão também daqueles usuários menos 
abastados de conhecimentos técnicos se mostra condição necessária e favorável à esfera do controle social.

Na esteira dessas evidências, o Accounting Principles Board, por meio do APB n ${ }^{\circ}$ 4, de 1964, ao citar as características qualitativas da informação contábil considera que a compreensibilidade está alinhada não só a seleção das informações mais inteligíveis, mas sim ao fato destas proporcionarem entendimento aos usuários. Por este motivo, esse tipo de entendimento na área de saúde deve focar também os usuários que não detêm conhecimento mais aprofundado das questões que permeiam a gestão da saúde, de modo que se possa buscar controle das ações do SUS, via prestação de contas à sociedade. Um exemplo para elucidar este caso é a apresentação, via relatório de contas, da alocação de recursos na atenção à saúde básica dentro de determinado município. Ocorre que as informações podem não ser suficientemente claras para um usuário, ao passo que podem ser triviais para um contador ou analista de orçamento que compõe uma comissão de orçamento e prestações de contas. Portanto, o exercício das atribuições de um conselheiro pode ser prejudicado.

Ainda com respeito a essa linha, para Schroeder (2001) a compreensibilidade envolve aspectos tanto dos usuários quanto das próprias características qualitativas da informação e por conta disso estabelece ligação entre a informação e os responsáveis pela tomada de decisão. Dias Filho (2001), considera a compreensibilidade como característica importantíssima para que informações possam atingir a eficácia de se fazerem claras, concisas, sobretudo àqueles usuários que não sabem determinar quais são a informações adequadas para um relatório.

Por outro lado, o IASC (2001) considera que informações complexas, porém relevantes, para o processo decisório não devem ser excluídas sob o argumento de que parte de seus usuários não as entendam. Para o presente trabalho, esta vertente abre espaço para dois aspectos, a saber: i) informações importantes podem ser excluídas do relatório de prestação de contas; e ii) informações desnecessárias que podem ser incluídas sem haver ganho informacional para os usuários. O que se discute nesse caso é a questão da ausência ou presença de determinadas informações prejudicarem ou auxiliarem a compreensão dos relatórios de prestação de contas da SES.

Em relação à tempestividade Campelo (2012) a considera como característica análoga à oportunidade. A justificativa pode ser dada ao se pensar que a informação divulgada 
em tempo hábil, ou seja, oportunamente, para auxiliar no processo decisório, é ferramenta importante para decidir os rumos de uma entidade. Entretanto, o CPC 00 (R1) (2013, p. 21) afirma que "certa informação pode ter o seu atributo tempestividade prolongado após o encerramento do período contábil, em decorrência de alguns usuários, por exemplo, necessitarem identificar e avaliar tendências". Logo, cabe enfatizar a possibilidade de fatos passados, incialmente sem valor por não terem sido tempestivos, poderem adquirir este aspecto mesmo de forma tardia.

Wolk et al. (2004) afirma que para ser relevante, a informação deve ser oportuna, o que significa dizer que deve estar disponível para os tomadores de decisão antes que ela perca a sua capacidade de influenciar nas decisões. Portanto, existe relação entre a tempestividade e a relevância da informação. Todavia, o autor faz referência a conflitos existentes entre outras características ligadas a relevância, pois quanto mais completas e acuradas forem as informações a tendência é relaxar a restrição do tempo - sendo, assim, menos tempestiva.

Adicionalmente, Soares (1998) afirma que mesmo uma informação contábil próxima da realidade, se feita oportunamente, tem mais importância do que aquela informação precisa disponibilizada de forma tardia. Para os Conselhos de Saúde essa é uma realidade, às vezes, presente no processo deliberativo, pois o atraso de uma informação que pode auxiliar nas decisões realizadas em reuniões ordinárias pode vir a prejudicar o exercício das atribuições dos conselheiros e, consequentemente, do controle social. No tocante à aplicação da tempestividade no contexto dos relatórios de prestação de contas é possível pensar na periodicidade em que estas são disponibilizadas aos CES e no momento após a sua apreciação - o qual emite-se parecer a respeito das contas apresentadas pela SES.

Por fim, a verificabilidade permite que os usuários se assegurem a respeito da fidedignidade da informação que o fenômeno econômico objetiva representar (CPC, 2010). O Comitê ainda estabelece dois tipos de verificabilidade: a direta e indireta. A primeira consiste "verificar um montante ou outra representação por meio da observação direta" e a segunda "significa checar os dados de entrada do modelo, fórmula ou outra técnica e recalcular os resultados obtidos por meio da aplicação da mesma metodologia”. Especificamente para esta característica, a aplicação ao contexto de avaliação das prestações de contas se mostra inviável pela falta de contato com a elaboração dos relatórios, acesso a informações complementares e demais processos atinentes a esta fase. Portanto, só seria possível verificar os montantes de recursos apresentados nos relatórios de prestações de contas da SES. Após a síntese das 
características qualitativas de melhoria a figura 2 insere quadro esquemático das mesmas.

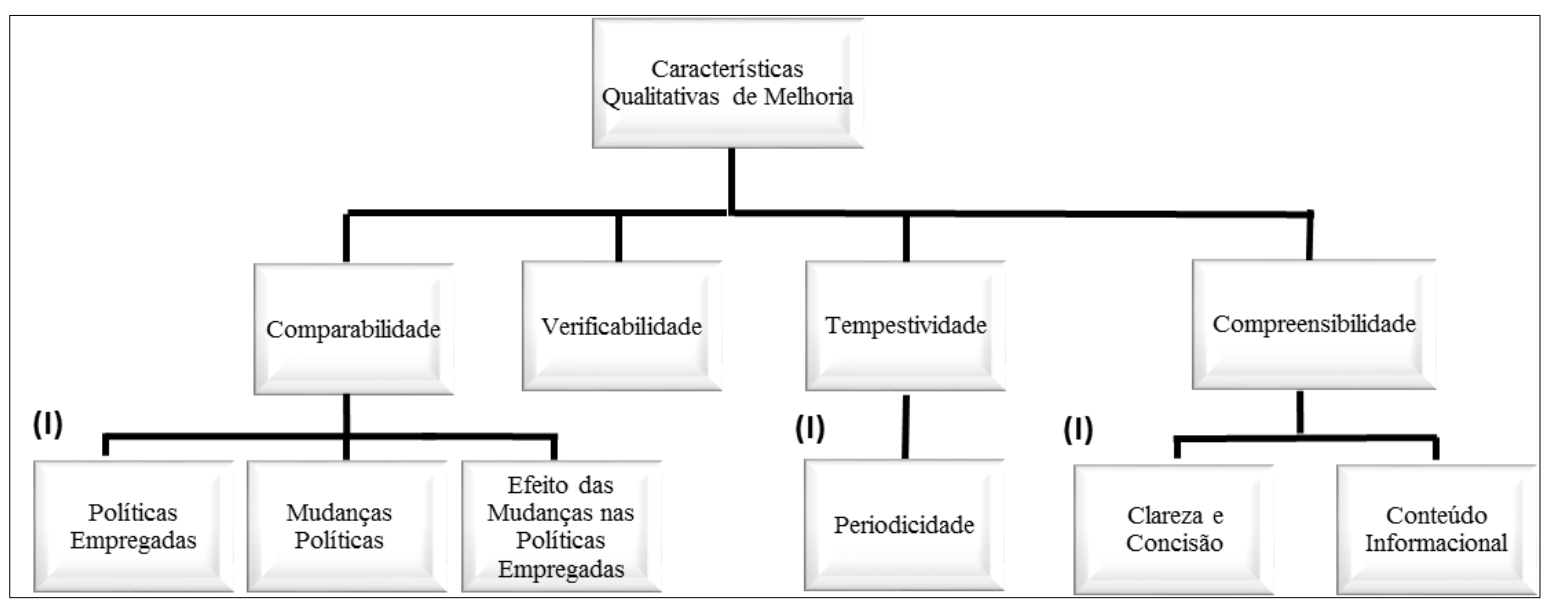

(I) - Indicadores.

Figura 2 - Características Qualitativas de Melhoria.

Fonte: Elaboração própria.

Após apresentar sustentação teórica para desenvolver o empreendimento problemático desta pesquisa faz-se necessário apresentar a maneira pela qual se buscou atacalo: possibilidade da maior participação social incrementar a qualidade dos relatórios de prestação de contas das Secretaria Estaduais de Saúde. 


\section{DESENHO METODOLÓGICO}

A pesquisa permeia duas abordagens distintas, porém, relacionáveis. A amplitude de participação social e a prestação de contas - a última de acordo com a perspectiva dos aspectos qualitativos da informação contábil. Essas duas abordagens tiveram como objeto de estudo os Conselhos Estaduais de Saúde da Região Centro Oeste, excluindo-se o conselho do Distrito Federal. A razão pela qual se excluiu o referido Conselho tem como justificativa o fato deste acumular funções de Conselho Estadual e Municipal, o que poderia causar viés na análise entre os demais.

A motivação para a escolha dos Conselhos dessa região - Centro Oeste - se deu em virtude de estudos anteriores tanto na parte da qualidade dos relatórios de prestações de contas (GONÇALVES et al., 2010; GONÇALVES et al., 2011; REZENDE, 2013; GONÇALVES et al., 2013) quanto na de amplitude de participação social (SILVA, 1999; GONÇALVES, GONÇALVES, WEFFORT, 2005) terem abarcado outras regiões ${ }^{18}$. Outrossim, cabe salientar que essa região possui a segunda maior extensão do país, 18,9\% do território nacional (CENSO, 2010). Além disso, recebeu do governo federal em 2013 o montante de R \$ 10,8 bilhões para realizar investimentos em saneamento, assistência social e transporte. Dessa maneira, é possível vislumbrar que a região Centro Oeste é relevante para análise de vários aspectos, sobretudo os destacados na problemática desta pesquisa.

Logo, é importante saber como se dá alocação desses recursos no sentido de atender às necessidades da sociedade em matéria de saúde. Diante disso, pode-se dizer que as ações dos gestores da saúde precisam estar inseridas nos relatórios de prestação de contas de modo a possibilitar que o cidadão possa fiscalizá-las, promovendo, assim, o controle social. O envolvimento da sociedade, visto aqui como participação social, na vigilância das ações de saúde pública se insere nessa conjuntura com o objetivo de incentivar os gestores a prestarem contas da sua gestão - promovendo mais transparência e gerando melhorias para a saúde.

\footnotetext{
${ }^{18}$ Estudos a respeito da qualidade da informação dos relatórios de prestação de contas, no âmbito de Secretarias Estaduais de Saúde, ocorreram no Paraná, Santa Catarina, Rio Grande do Sul, Espirito Santo, Rio de Janeiro e Distrito Federal. Por outro lado, foram realizados, também, estudos nos municípios de Anápolis (Goiás) e Natal (Rio Grande do Norte). Já com relação à amplitude de participação social foram realizados estudo em Porto Alegre (Rio Grande do Sul - Brasil) e Montevidéu (Uruguai).
} 
Para avaliar a possiblidade da amplitude de participação social incrementar o nível de divulgação das prestações de contas são requeridos aspectos metodológicos diferenciados e complementares. Oportunamente, salienta-se que a pesquisa detém cunho necessariamente qualitativo em ambas. Incialmente é possível classificar o estudo da amplitude da participação social, quanto ao método, como estudo de casos múltiplos. Este método pode ser considerado como forma de se fazer pesquisa social empírica com o intuito de investigar um fenômeno inserido no seu contexto local e real (YIN, 2011). Nesse sentido, buscou-se avaliar os Conselhos Estaduais de Saúde (CES) da região Centro Oeste com foco na dimensão de amplitude de participação social e na dimensão histórica utilizando, parcialmente ${ }^{19}$, um instrumento de pesquisa desenvolvido por Silva (1999), sustentado teoricamente em Rifkin et al. (1989) e Demo (2001). As duas dimensões citadas possuem quatro indicadores, a saber: avaliação das necessidades, liderança; mobilização de recursos e implantação de departamentalização.

As duas frentes mencionadas - dimensão da amplitude de participação e dimensão histórica - buscam avaliar tendência da amplitude de participação social dos Conselhos. Por conseguinte, os elementos necessários para esta finalidade perpassam a figura dos conselheiros e de documentos que forneçam suporte à proposta deste trabalho. Portanto, foram empregadas para a coleta de dados as técnicas de entrevistas semiestruturadas (GUBER, 2001) e documental (GIL, 2008), respectivamente. A investigação da amplitude da participação da comunidade foi montada de modo a elencar quatro níveis (escalas) de participação social, quais sejam: ampla, aberta, média e restrita (SILVA, 1999).

Já com respeito à qualidade da informação presente nos relatórios de prestações de contas encaminhados pelas Secretarias Estaduais de Saúde aos Conselhos Estaduais de Saúde foi utilizado um instrumento de pesquisa proposto por Gonçalves et al. (2010), validado por Rezende (2013) - com base nas características qualitativas da informação contábil. A sustentação teórica para as referidas características qualitativas toma como referência Hendriksen e Van Breda (2011); e Glautier e Underdown (2001). Ao adentrar os aspectos da segunda abordagem, prestações de contas, no que diz respeito ao método, o estudo de casos múltiplos é mantido, ao passo que à técnica empregada passa a ser apenas a documental.

Para este estudo as características qualitativas são avaliadas a partir de três

\footnotetext{
${ }^{19}$ Os elementos teóricos da Dimensão da Gestão abordada por Likert (1975) e inserida por Silva (1999) em seu instrumento não foram trabalhados nesta pesquisa.
} 
dimensões, quais sejam: relevância, representação fidedigna e tempestividade, diferentemente das pesquisas anteriores (GONÇALVES et al., 2010; GONÇALVES et al., 2011; REZENDE, 2013; GONÇALVES et al., 2013). Ocorre que houve uma atualização ${ }^{20}$ no que se refere às características qualitativas da informação contábil preceituadas no CPC 00 (R1) (2010), constituindo características qualitativas fundamentais e de melhoria. Como exemplo das alterações, a materialidade, antes abordada como dimensão, passou a ser considerada como subdimensão da relevância. As dimensões e a subdimensão possuem 11 indicadores e 13 variáveis a serem classificadas como restrita, baixa, média e ampla (GONÇALVES et al., 2010).

Os dados coletados ${ }^{21}$ para esta pesquisa compreenderam o período de 2011 a 2013 com a finalidade de descrever a qualidade da informação dos relatórios de prestação de contas das três SES (Goiás, Mato Grosso e Mato Grosso do Sul). Como justificativa para a escolha do período buscou-se analisar o último governo (2011-2014) dos Estados em questão, no sentido de verificar, via prestação de contas, a aplicação de recursos públicos para área da saúde, considerando ações empregadas pelo gestor com o objetivo de atender às necessidades da sociedade. Nesse sentido, entende-se que o relatório de prestação de contas deveria apresentar como está sendo gerida a saúde para determinado Estado ou Município. Em face disso, buscouse analisar a gestão de 2011 a 2014 com o intuito de obter um pouco mais de homogeneidade nas ações praticadas pelo governo, dado que, em tese, a forma de conduzir as ações do Estado teria uma linha defina. Ressalta-se, ainda, que nem todos os dados relativos às prestações de contas de 2014 estavam disponíveis para análise desta pesquisa. A razão pela qual não foi possível avaliar o ano de 2014 está imbricada na questão dos relatórios não terem sido disponibilizados tempestivamente, bem como não terem sido avaliados para emissão de pareceres, por parte do CES, sobre as contas apresentadas.

\footnotetext{
20 Será abordada com maior profundidade em item específico. As dimensões da Comparabilidade e Compreensibilidade, contidas no CPC 00 (R1) (2010), não foram utilizadas para complementar o instrumento de Gonçalves et al (2010) pela impossibilidade de aplicação prática.

${ }^{21}$ Exceto para as atas das reuniões plenárias e entrevistas que compreendem um corte longitudinal maior para análise da dimensão histórica.
} 


\subsection{Amplitude de Participação Social}

\subsubsection{Dimensão da Amplitude de Participação Social}

Fleury e Lobato (2009) consideram que a amplitude de participação social pode condicionar o processo deliberativo. Nesse sentido, essa amplitude figura como elemento que atua diretamente no processo deliberativo, no caso desta pesquisa, dos Conselhos de Saúde. A dimensão do estudo de amplitude de participação social compreende indicadores ligados a avaliação de necessidades, liderança e mobilização de recursos - todos responsáveis por constituir a subdimensão de tradução de demandas (SILVA, 1999). Para tratar a dimensão da amplitude de participação social foi utilizada a técnica de entrevista em profundidade semiestruturada. Consoante a isso, foram utilizadas perguntas baseadas em as categorias teóricas definidas por Silva (1999) para realizar entrevistas. Dessa forma, foram entrevistados conselheiros estaduais de saúde dos CES de Goiás, Mato Grosso e Mato Grosso do Sul objetivando verificar, por meio de um roteiro previamente definido22, a tendência da amplitude de participação social da comunidade, nas ações de saúde pública do Estado. O quadro 01 apresenta a composição da dimensão da amplitude de participação juntamente com seus indicadores, bem como os categoriza, em termos de tendência de amplitude de participação social, como ampla, aberta, media e restrita.

\begin{tabular}{|c|c|c|c|}
\hline \multicolumn{4}{|c|}{ Dimensão Amplitude de Participação } \\
\hline \multicolumn{4}{|c|}{ Subdimensão Tradução de Demandas } \\
\hline \multicolumn{4}{|c|}{ Avaliação de necessidades (RIFKIN et al, 1989) } \\
\hline Ampla & Aberta & Média & Restrita \\
\hline $\begin{array}{l}\text { A comunidade intervém na avaliação de } \\
\text { necessidades }\end{array}$ & $\begin{array}{l}\text { O CES representa ativamente o ponto de } \\
\text { vista da comunidade e avalia as } \\
\text { necessidades }\end{array}$ & $\begin{array}{l}\text { A coordenação representa o ponto de } \\
\text { vista e avalia as necessidades }\end{array}$ & $\begin{array}{l}\text { A opinião técnica das SES do Centro } \\
\text { Oeste predomina, levando em conta os } \\
\text { interesses da comunidade }\end{array}$ \\
\hline \multicolumn{4}{|c|}{ Subdimensão Tradução de Demandas } \\
\hline \multicolumn{4}{|c|}{ Liderança (RIFKIN et al., 1989 e DEMO, 1996) } \\
\hline Ampla & Aberta & Média & Restrita \\
\hline $\begin{array}{l}\text { O CES representa toda a diversidade de } \\
\text { interesses da comunidade e controla as } \\
\text { atividades do gestor estadual de saúde; }\end{array}$ & O CES é ativo com iniciativa & $\begin{array}{l}\text { O CES funciona sob um gestor estadual } \\
\text { de saúde independente }\end{array}$ & $\begin{array}{l}\text { O CES não funciona, mas o gestor } \\
\text { municipal de saúde atua independente dos } \\
\text { grupos de interesse. }\end{array}$ \\
\hline \multicolumn{4}{|c|}{ Subdimensão Tradução de Demandas } \\
\hline \multicolumn{4}{|c|}{ Mobilização de recursos (RIFKIN et al., 1989) } \\
\hline Ampla & Aberta & Média & Restrita \\
\hline $\begin{array}{l}\text { A política local de saúde obtém } \\
\text { considerável volume de recursos de } \\
\text { origens diversas; o CES é quem decide a } \\
\text { utilização dos recursos do Fundo estadual } \\
\text { de Saúde }\end{array}$ & $\begin{array}{l}\text { Ocorre contribuição periódica da União, } \\
\text { do Estado e do Município; o CES controla } \\
\text { a utilização dos gastos }\end{array}$ & $\begin{array}{l}\text { Ocorre contribuição periódica da União, } \\
\text { do Estado e do Município, sem a } \\
\text { participação da comunidade no controle } \\
\text { dos gastos; }\end{array}$ & $\begin{array}{l}\text { Os recursos são provenientes } \\
\text { prestação de } \\
\text { controla o pagamento dos honorários. }\end{array}$ \\
\hline
\end{tabular}

Quadro 1 - Resumo esquemático do instrumento de pesquisa - Amplitude da Participação

Fonte: Silva (1999) com adaptações.

22 O roteiro da entrevista foi compilado por Silva (1999) e está ancorado em estudos realizados por Rifkin et al. (1989) e Demo (2001). Ver anexo A. 
O primeiro indicador da subdimensão tradução de demandas - avaliação das necessidades - verifica quais atores fazem parte do diagnóstico das necessidades de saúde, o quanto estes participam e como identificam alguma necessidade (SILVA, 1999). O objetivo é verificar como as necessidades advindas da saúde são recepcionadas pelos CES, bem como se abordam questões ligadas exclusivamente à matéria de saúde.

Outro indicador - Liderança - considera o quanto os Conselhos de Saúde atendem às demandas da sociedade, os interesses que representam e as eventuais melhorias inseridas no processo deliberativo do CES (SILVA, 1999). Sendo assim, os objetivos desse indicador estão alinhados à ideia de verificar se a liderança existente no CES responde às necessidades da comunidade e, por consequência, produz melhorias para ela.

Por fim, o indicador de mobilização de recursos é responsável por analisar qual a medida de apoios obtidos que não estão diretamente vinculados à política de saúde local, quais os interesses responsáveis pela destinação de recursos e, por fim, qual é a contribuição da comunidade na alocação de recursos (SILVA, 1999). Nesse caso objetiva-se verificar, na percepção dos conselheiros, se os governos federal, estadual e municipal garantem que os recursos previstos no orçamento sejam repassados, bem como se sua distribuição está de acordo com o Plano Estadual de Saúde.

\subsubsection{Dimensão Histórica dos Conselhos Estaduais de Saúde}

A dimensão histórica por meio do indicador implantação e departamentalização objetiva verificar questões relacionadas ao processo de como se deu a implantação do CES, como este se organiza em novas estruturas, como integra novos temas de saúde e que mudanças ocorreram desde a implantação (SILVA, 1999). Dentro desta realidade, destaca-se que categorização da tendência da amplitude de participação social relacionada à implantação departamentalização do CES pode ser classificada novamente como ampla, aberta, média e restrita - conforme quadro 02 .

\begin{tabular}{|c|c|c|c|}
\hline \multicolumn{4}{|c|}{ Dimensão Histórica } \\
\hline \multicolumn{4}{|c|}{ Implantação e Departamentalização (RIFKIN et al, 1989 e DEMO, 1996) } \\
\hline Ampla & \begin{tabular}{|c|c|} 
Aberta & \\
\end{tabular} & Média & Restrita \\
\hline $\begin{array}{l}\text { As organizações comunitárias existentes } \\
\text { participaram da criação do CES e } \\
\text { participam ativamente das atividades do } \\
\text { CES. }\end{array}$ & $\mid \begin{array}{l}\text { CES foi implantado pela legislação mas } \\
\text { coopera ativamente com outras } \\
\text { organizações da comunidade, agregando } \\
\text { novos atores em comissões existentes. }\end{array}$ & $\begin{array}{l}\text { O CES foi imposto pelos serviços de } \\
\text { saúde, mas passou a ser plenamente } \\
\text { ativo, criando comissões. }\end{array}$ & $\begin{array}{l}\text { O CES foi imposto pelos serviços de } \\
\text { saúde, mas tem alguma atividade. }\end{array}$ \\
\hline
\end{tabular}

Quadro 2 - Resumo esquemático do instrumento de pesquisa - Amplitude da Participação. Fonte: Silva (1999) com adaptações. 
Todavia, existem dois fatores que merecem destaque nesta abordagem. O primeiro deles está relacionado ao fato de que além das entrevistas realizadas para verificar a percepção dos conselheiros de saúde em relação ao indicador de implantação e departamentalização procedeu-se a análise documental das atas plenárias das reuniões dos Conselhos. Por oportuno, salienta-se que todas atas das reuniões, considerando o intervalo da criação ao momento atual, deveriam estar transcritas e disponíveis para que qualquer cidadão pudesse ter acesso no sentido de se inteirar daquilo que é discutido e decido no CES. Contudo, foi constatado nos três conselhos analisados que só havia registros mais recentes das atas - concentrados no intervalo de 2005 a 2013. Sob este prisma, já é possível considerar que houve descumprimento dos art. 17, incisos I, II e III - CES/GO; art. CES/MT; art. 47, $\S$ primeiro, inciso III - CES/MS; em relação aos seus respectivos regimentos internos. Isto, por consequência, inviabiliza a capacidade do cidadão se inteirar do que é discutido pelo CES. O fato de todas as atas não estarem disponíveis para análise documental desta pesquisa motivou a realização de uma entrevista semiestruturada com o conselheiro mais antigo em cada CES. O objetivo foi aprofundar o estudo da dimensão histórica para tentar suprir a ausência de grande parte das atas. Esta abordagem é discutida de forma mais específica no item 3.1.2.1.

O segundo ponto de destaque faz referência à necessidade de contextualizar o indicador implantação e departamentalização em virtude da sua especificidade - analisar a trajetória do CES a partir de uma incursão momentânea. Assim, como forma de justificar uma intervenção pontual a partir de um corte temporal mais amplo, realizado para verificar a dimensão histórica, pegou-se emprestado um conceito trabalhado por Gramsci (1981). Para o autor trata-se de um conceito pensado a partir de perspectivas históricas cujo foco está alinhado à ideia de que o entendimento das pessoas, em geral, acerca de determinados aspectos, é proveniente de sedimentação histórica, ou seja, de valores e demais elementos formados ao longo do tempo. Face ao exposto, destaca-se que a mesma concepção pode ser aplicada à formação dos Conselhos, pois não seria razoável refutá-la.

No que tange ao foco desta etapa - dimensão histórica da amplitude de participação social - as mudanças ocorridas, nos indicadores de departamentalização e implantação do CES, mesmo analisados a partir de uma intervenção pontual, são importantes e necessárias para promover o entendimento da evolução e formação do conselho, pois enfatizam e clarificam o 
processo de participação social deste. Ao seguir essa perspectiva, a análise da tendência de amplitude de participação social fica mais rica haja vista que as considerações advindas de cruzamentos informacionais entre os indicadores podem eventualmente trazer inferências mais robustas.

Adicionalmente, Demo (2001, p. 13) corrobora esse pensamento ao discorrer a respeito de participação e considerar que "trata-se de um processo histórico infindável, que faz da participação um processo de conquista de si mesma”. Logo, para avaliar o processo de formação do CES parte-se de um corte longitudinal mais amplo que possa verificar elementos que forneçam suporte à análise dos indicadores ora propostos.

Diante das motivações expendidas neste tópico, surge um questionamento relacionado ao método mais adequado para recepcionar e fornecer meios para que esses elementos - pertencentes às duas dimensões, ora abordadas - possam ser verificados e interpretados de acordo com a proposta deste texto. Como resposta, Ferreira e Amado (2006) ${ }^{23}$ argumentam que a História Oral sob a perspectiva de método é uma ponte que abre espaço para procedimentos de trabalho como, por exemplo, a transcrição de depoimentos - no caso entrevistas com conselheiros - que podem traçar panoramas históricos. Ainda nessa linha, avalia-se que o método, como dito anteriormente, está alinhado justamente à questão da sedimentação histórica.

Ao se ancorar no fragmento que aborda história oral como o método norteador de técnicas é possível entender que este acaba por orientar a técnica de entrevista em profundidade realizada em cada Conselho, inclusive com os conselheiros mais antigos, bem como orienta, também, à análise documental das atas das plenárias em virtude da perspectiva histórica contida nelas. Destarte, a aderência do método história oral a esta pesquisa se justifica de maneira apropriada.

Segundo Matos e Senna (2011, p. 96) “a fonte oral pode acrescentar uma dimensão viva, trazendo novas perspectivas [...] muitas vezes, necessita de documentos variados, não apenas os escritos”. Os autores mencionam, ainda, que em meio à pluralidade da sociedade moderna a oralidade se destaca no processo difusor da informação. Para instâncias deliberativas como é o caso deste trabalho a oralidade ganha relevância na relação participativa entre Estado

\footnotetext{
${ }^{23}$ Para maiores informações ver "Usos e abusos da história oral (2006)”.
} 
x sociedade.

Thompson (1992) corrobora essa ideia quando afirma que a memória de alguns pode ser a memória de muitos e, por consequência, possibilita acesso a evidências em âmbito coletivo - retrato da função precípua dos conselhos. Já Portelli et al. . (2006) afirmam que a pressão para não se esquecer de determinados fatos históricos na verdade preserva as lembranças de grupos de pessoas, o que pode se traduzir em controle social - na medida em que diante fatos a comunidade possa avaliá-los.

Como forma de dar suporte ao método da história oral, no tocante às entrevistas em profundidade, aplica-se a análise de conteúdo. Silva e Fossá (2013) consideram que análise de conteúdo é uma técnica de análise das comunicações, responsável por analisar o que foi dito em entrevistas ou observado pelo pesquisador em documentos. As autoras ainda destacam que na análise de materiais o intuito é classificá-los em categorias ou em temas com a finalidade de prover maior compressão acerca da proposta de pesquisa.

Sob essa perspectiva, a aplicação da análise de conteúdo depreende algumas etapas a serem realizadas para que o estudo possa ter o rigor metodológico assegurado. Bardin (2006) propõe três fases para aplicação da análise de conteúdo, quais sejam: a) pré-análise (estabelecimento de indicadores de acordo com a plataforma teórica); b) exploração dos materiais (construção das operações de codificação ${ }^{24}$ ), e c) tratamento dos resultados, inferências e interpretação (captar o conteúdo existente no material e discuti-lo). Quanto ao instrumento de pesquisa compilado por Silva (1999) as características implícitas às fases em epígrafe foram validadas seguindo o rigor metodológico necessário.

Para efeito desta pesquisa soma-se ao instrumento formulado pela por Silva (1999), um roteiro de questionamentos relacionados a temas, e não mais categorias, para analisar os materiais coletados nas entrevistas com os conselheiros mais antigos, indicados pelos próprios Conselhos. O quadro a seguir sintetiza o ambiente da dimensão histórica dos Conselhos e apresenta o meio pelo qual se desenvolveu a sua análise.

\footnotetext{
${ }^{24}$ Bardin (1977) conceitua o termo codificação como meio pelo qual se transforma a enumeração e a agregação de informações textuais - a partir de regras bem definidas - em informações mais representativas em termos de conteúdo.
} 


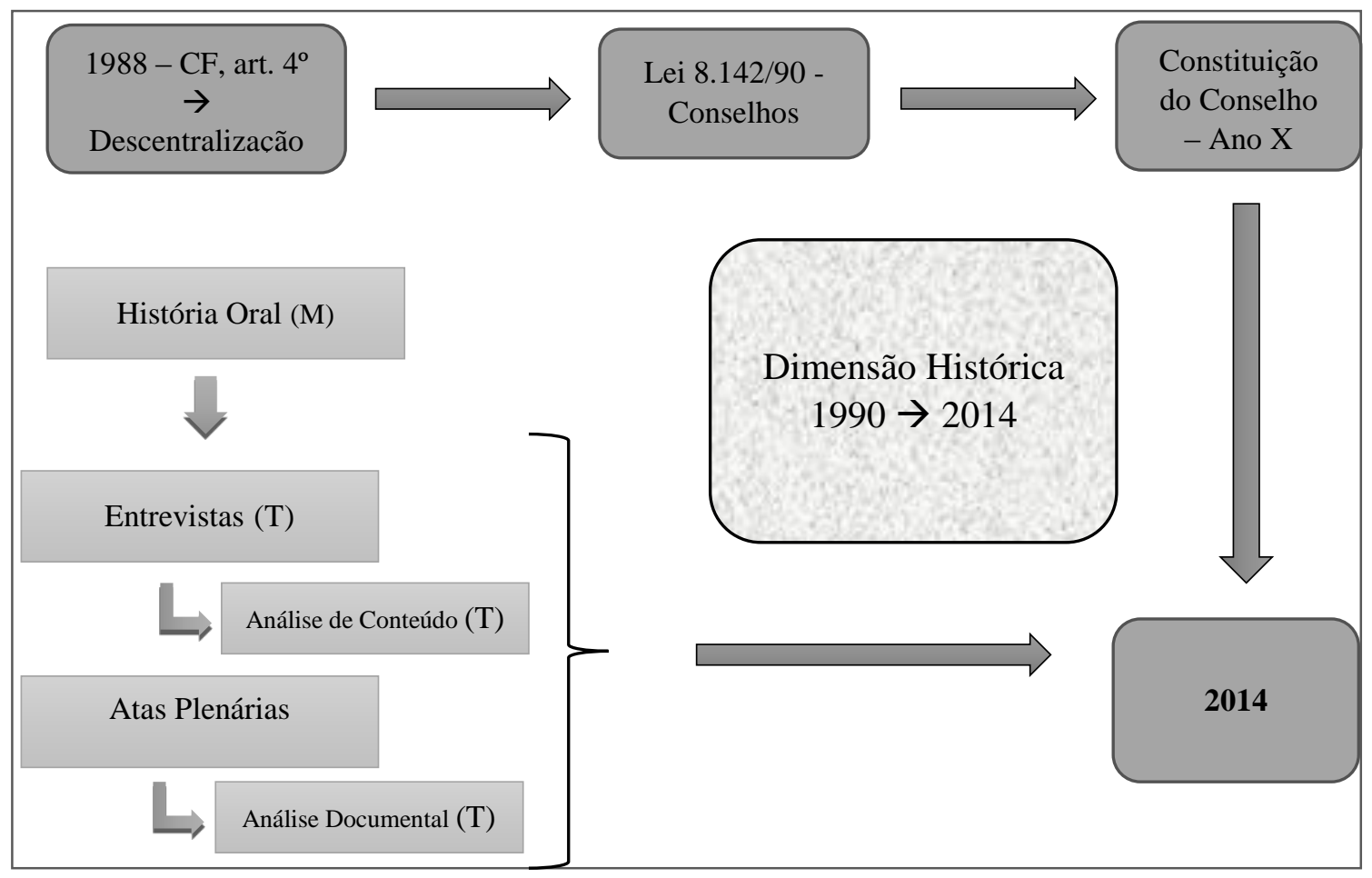

(M) Método / (T) Técnica

FIGURA 3 - Resumo esquemático da dimensão histórica.

Fonte: elaborado pelo autor.

\subsubsection{Entrevista em profundidade com conselheiro mais antigo do CES}

A realização de entrevista com o conselheiro mais antigo tem por finalidade complementar - em virtude da ausência das atas - a visão do indicador implantação $e$ departamentalização, abordado na dimensão da amplitude da participação por Silva (1999). Diante desse propósito, foram elaboradas questões ${ }^{25}$, com base em temas; e não mais em categorias, de modo a compilar roteiro para a entrevista em profundidade - semiestruturada. A entrevista em profundidade é uma técnica qualitativa responsável pela investigação de determinados assuntos e tem como foco a busca de percepções, informações e experiências de indivíduos de modo que se possa realizar, posteriormente, análise que seja apresentada de maneira estruturada (BARROS; DUARTE, 2006).

Os autores afirmam, ainda, que essa técnica é dinâmica e flexível para capturar a realidade tanto de questões ligadas a aspectos íntimos dos sujeitos, como para descrever processos complexos nos quais estes estão ou estiveram envolvidos de alguma forma. Além

\footnotetext{
${ }^{25}$ Barros e Duarte (2006) afirmam que as questões possuem origem no problema da pesquisa e têm por finalidade tratar da amplitude do tema - que no caso desta pesquisa está justamente alinhado à tendência de amplitude de participação social e sua influência na qualidade dos relatórios remetidos pela SES.
} 
disso, as entrevistas em profundidade podem ser classificadas da seguinte maneira: não estruturadas, semiestruturadas e estruturadas. A entrevista não estruturada é aplicada sem roteiro previamente delimitado e tem como foco apenas um tema central, enquanto a semiestruturada se utiliza de roteiro base. A similaridade entre as duas é que em ambas existe flexibilidade e os temas são explorados ao máximo a partir das respostas dos indivíduos entrevistados. Por fim, a entrevista estruturada, mais utilizada em pesquisas quantitativas, possui menos flexibilidade por assumir muitas vezes a forma de questionários (BARROS; DUARTE, 2006).

Não obstante, Guber (2001) argumenta que entrevistas abertas (não estruturadas e semiestruturadas) estão alinhadas à participação do pesquisador nos termos da figura do entrevistado - e suas percepções -, ao passo que nas entrevistas fechadas a participação dos entrevistados ocorre nos termos do pesquisador. Para efeito desta pesquisa, os conselheiros de saúde são o foco base para avaliar a tendência da amplitude participação social dos CES e, portanto, a participação do pesquisador ocorre nos termos dos conselheiros.

A partir da transcrição das entrevistas realizadas com os referidos conselheiros, empregou-se a análise de conteúdo para coletar as percepções dos indivíduos em relação aos aspectos que permeiam o desenvolvimento histórico da participação social dos CES no Centro Oeste. Contudo, nesta etapa a elaboração do roteiro se deu por meio de temas e não por categorias teóricas - opção mencionadas por Silva e Fossá (2013). O quadro a seguir apresenta o roteiro e seu embasamento teórico para a entrevista com o conselheiro mais antigo. 


\begin{tabular}{|c|c|c|}
\hline \multicolumn{2}{|r|}{$\begin{array}{l}\text { Dimensão Histórica - Roteiro } \\
\text { Entrevista Semiestruturada }\end{array}$} & \multirow[t]{2}{*}{ Justificativa / Objetivo } \\
\hline (1) & $\begin{array}{l}\text { Como ocorreu a implantação } \\
\text { do conselho? i) De quem } \\
\text { partiu a iniciativa? ii) Houve } \\
\text { envolvimento da população? }\end{array}$ & \\
\hline (2) & $\begin{array}{l}\text { Como ocorreu } \\
\text { nomeação/eleição } \\
\text { primeiros conselheiros (fos } \\
\text { formal)? i) foram constituídos } \\
\text { de forma paritária? ii) e as } \\
\text { demais como ocorreram ao } \\
\text { longo do tempo? }\end{array}$ & $\begin{array}{l}\text { Ao tratar da questão paritária é importante destacar possíveis justificativas para sua aplicabilidade. } \\
\text { Moreira et al. (2006) discutem uma delas e afirmam que ao considerar a paridade entre usuários e os } \\
\text { outros componentes é possível avaliar, eventualmente, um maior nível de autonomia e } \\
\text { democratização dos conselhos. Portanto, o foco deste item objetiva verificar como se deram - no } \\
\text { primeiro momento e ao longo do tempo - as nomeações/eleições dos conselheiros e se, } \\
\text { principalmente, a paridade foi aplicada nesses momentos. Por conseguinte, o intuito é perceber } \\
\text { indícios da maior autonomia do conselho em face do processo democrático. }\end{array}$ \\
\hline (3) & 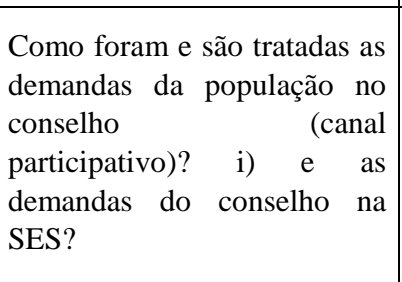 & $\begin{array}{l}\text { Putnam (1994) afirma que para um governo ser considerado eficiente e democrático não basta o fato } \\
\text { deste se mostrar sensibilizado pelas demandas da comunidade, pois é preciso promover uma gestão } \\
\text { eficaz que proponha, de fato, o atendimento aos anseios do cidadão. Sob este prisma, é importante } \\
\text { saber como o CES trata as demandas da sua comunidade e se efetivamente procura atende-las. Por } \\
\text { outro lado, objetiva-se entender, também, como se dá o tratamento das demandas do CES } \\
\text { encaminhadas à SES, pois estes fatores representam uma segunda análise do atendimento às } \\
\text { necessidades da sociedade. }\end{array}$ \\
\hline (4) & $\begin{array}{l}\text { Como se deu o processo de } \\
\text { criação de comissões em } \\
\text { virtude das demandas } \\
\text { comunidade (ao longo do } \\
\text { tempo)? }\end{array}$ & $\begin{array}{l}\text { Avritzer (2007) entende que as comissões que se estruturam dentro de instituições participativas } \\
\text { indicam a intenção de mitigar questões ligadas a assimetria informacional entre os participantes do } \\
\text { processo de gestão da saúde. O autor considera ainda que o objetivo é disponibilizar a todos a } \\
\text { possibilidade de maior participação no processo decisório, pois a discussão dos conselheiros que as } \\
\text { compóem, teoricamente, em alguma parcela, representam a sociedade. Com efeito, o objetivo deste } \\
\text { tópico é verificar como se deu a criação dessas comissões e, mais do que isso, se essas realmente } \\
\text { surgiram em virtude das demandas da sociedade - resultantes da redução de assimetria informacional } \\
\text { preceituada por Avritzer (2007). }\end{array}$ \\
\hline (5) & $\begin{array}{l}\text { Como se deu a participação } \\
\text { das entidades representativas } \\
\text { nas deliberações do conselho } \\
\text { ao longo do tempo? }\end{array}$ & $\begin{array}{l}\text { Ao considerar eventual participação de entidades representativas nas deliberações do CES insere-se } \\
\text { mais uma ferramenta para avaliar o quanto este é participativo. Cumpre-se destacar que mesmo } \\
\text { havendo integrantes dessas entidades na formação do CES é possível que estes não busquem levar as } \\
\text { pautas daqueles que representam para discussão nas plenárias. Face ao exposto, o objetivo aqui é } \\
\text { avaliar em uma perspectiva histórica o quão participativas foram essas entidades nas discussões do } \\
\text { conselho - no sentido de dar, novamente, suporte à avaliação da dimensão histórica da amplitude de } \\
\text { participação. }\end{array}$ \\
\hline (6) & $\begin{array}{l}\text { A comunidade se reconhece } \\
\text { como parte integrante do } \\
\text { processo de gestão da saúde? }\end{array}$ & $\begin{array}{l}\text { Segundo Silva, Cruz e Melo (2007) a democratização dos conselhos de saúde busca adotar práticas } \\
\text { que tenham como um de seus principais intuitos promover maior participação da sociedade na tomada } \\
\text { de decisão. Caso essa concepção venha a se efetivar em determinado município, por exemplo, é } \\
\text { possível considerar que ao estar mais envolvida a sociedade se perceba como parte integrante da } \\
\text { gestão da saúde local. Logo, esse aspecto favorece a compreensão da amplitude de participação do } \\
\text { conselho. }\end{array}$ \\
\hline (7) & $\begin{array}{l}\text { Qual a influência de questões } \\
\text { políticas por parte de } \\
\text { integrantes e não integrantes } \\
\text { do conselho nas deliberações } \\
\text { (ao longo da história do CES)? }\end{array}$ & $\begin{array}{l}\text { Paim e Teixeira (2007) consideram que a ocorrência de mudanças de concepções - ocasionadas em } \\
\text { virtude de alternâncias nas posições políticas de agentes que fazem parte do SUS - indica } \\
\text { preponderância de articulações ligadas a interesses político-partidários. Os autores ainda consideram } \\
\text { que isto sobrepõem o debate acerca de funções e competências dentro do SUS de forma geral. Por } \\
\text { oportuno, não se pode refutar a ideia de que os elementos expostos podem estar presentes no CES. } \\
\text { Dessa forma, o objetivo é entender se essas questões impactam os conselheiros e, por conseguinte, o } \\
\text { processo deliberativo do conselho. }\end{array}$ \\
\hline
\end{tabular}

Quadro 3 - Roteiro da entrevista semiestruturada para realizar com o conselheiro mais antigo do CES. Fonte: Elaboração própria. 


\subsubsection{Análise das Atas das Plenárias}

A análise das atas plenárias tem como objetivo complementar a análise da dimensão histórica dos Conselhos Estaduais de Saúde. A técnica empregada neste caso foi a análise documental. Todavia, é válido destacar, até como limitação da pesquisa, o fato dos Conselhos de Saúde não possuírem memória transcrita - no caso atas - desde o período de criação da instituição participativa. $\mathrm{O}$ quadro 04 compila informações relacionadas às atas das plenárias que foram objeto deste estudo - de acordo com o período disponível para cada CES.

\begin{tabular}{|l|c|}
\hline \multicolumn{1}{|c|}{ CES Centro Oeste } & $\begin{array}{c}\text { Atas transcritas (período } \\
\text { disponível) }\end{array}$ \\
\hline Conselho Estadual de Saúde de Goiás & $2005-2006$ e 2013 \\
Conselho Estadual de Saúde de Mato Grosso & 2008 a 2013 \\
Conselho Estadual de Saúde de Mato Grosso do Sul & 2007 a 2013 \\
\hline
\end{tabular}

Quadro 4 - Atas disponíveis para análise nos Conselhos de Saúde.

Fonte: elaboração própria.

\subsubsection{Critérios de seleção dos conselheiros}

A seleção dos conselheiros seguiu o critério de paridade estabelecido pela Resolução

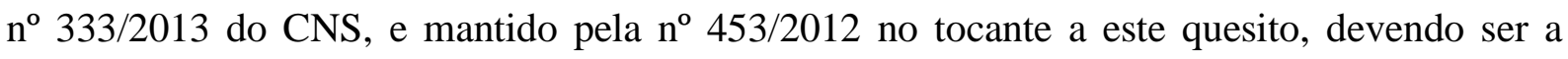
composição de cada CES distribuída da seguinte forma: 50\% representantes de entidades, instituições e movimentos representativos de usuários; 25\% entidades representativas de trabalhadores da área da saúde e, por fim, 25\% governo e Entidades representativas de prestadores de serviços de saúde. Após a comunicação prévia da necessidade de realizar entrevistas estas foram marcadas com os conselheiros por meio de consultas realizadas pelos Presidentes e/ou Secretários Executivos de cada conselho - de acordo com a disponibilidade de agenda de cada indivíduo.

Num primeiro momento foram entrevistados em cada instituição participativa oito conselheiros, totalizando 24 entrevistas. Estas foram responsáveis por buscar a percepção dos conselheiros no tocante à tendência da amplitude de participação social - conforme instrumento de Silva (1999). De forma complementar, foi realizada uma entrevista com o conselheiro mais antigo em cada conselho, totalizando três, objetivando avaliar com maior acurácia a dimensão histórica dessas instituições participativas. Por conseguinte, foram realizadas 27 entrevistas ao 
total nos conselhos de Goiás, Mato Grosso e Mato Grosso do Sul.

O CES de Goiás foi instituído pelo Decreto $n^{\circ} 3887 / 1992$, reestruturado pelos Decretos $n^{\circ} 4566 / 1995$ e 5.727/2003, e regulamentado por regimento interno. O conselho é composto de 20 conselheiros titulares seguindo o critério da paridade. Foram entrevistados oito conselheiros conforme quadro 05 para contemplar a sua percepção no tocante a amplitude de participação social. O conselheiro mais antigo entrevistado para avaliar a dimensão histórica pertence ao segmento dos usuários.

\begin{tabular}{|c|c|c|}
\hline Critério de Seleção & $\begin{array}{l}\text { (\%) Resolução } \\
\text { 453/2012 }\end{array}$ & $\begin{array}{l}\text { Quantidade } \\
\text { Conselheiros } \\
\text { CES/GO }\end{array}$ \\
\hline $\begin{array}{l}\text { Representantes de entidades, instituiçõos } \mathrm{e} \\
\text { movimentos representativos de usuários }\end{array}$ & $50 \%$ & 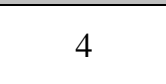 \\
\hline $\begin{array}{l}\text { Entidades representativas de trabalhadores da área } \\
\text { da saúde }\end{array}$ & $25 \%$ & 2 \\
\hline $\begin{array}{l}\text { Governo e Entidades representativas de } \\
\text { prestadores de serviços de saúde }(*)\end{array}$ & $25 \%$ & 2 \\
\hline \multicolumn{3}{|l|}{ (*) Um gestor e um prestador de serviço. } \\
\hline Fonte: elaboração própria & & \\
\hline
\end{tabular}

O CES de Mato Grosso foi instituído pelo Código Estadual de Saúde, via Lei Complementar $\mathrm{n}^{\circ}$ 22/1992, e regulamentado por regimento interno. O conselho é composto pelo Secretário de Saúde - presidente nato do CES - e mais 30 membros seguindo o critério da paridade. Foram entrevistados oito conselheiros conforme quadro 06 - novamente seguindo o critério de paridade contido na resolução 453/2012.

\begin{tabular}{|c|c|c|}
\hline Critério de Seleção & $\begin{array}{l}\text { (\%) Resolução } \\
453 / 2012\end{array}$ & $\begin{array}{l}\text { Quantidade } \\
\text { Conselheiros } \\
\text { CES/MS }\end{array}$ \\
\hline $\begin{array}{l}\text { Representantes de entidades, instituições e } \\
\text { movimentos representativos de usuários }\end{array}$ & $50 \%$ & 4 \\
\hline $\begin{array}{l}\text { Entidades representativas de trabalhadores da } \\
\text { área da saúde }\end{array}$ & $25 \%$ & 2 \\
\hline $\begin{array}{l}\text { Governo e Entidades representativas de } \\
\text { prestadores de serviços de saúde }(*)\end{array}$ & $25 \%$ & 2 \\
\hline
\end{tabular}

(*) Dois gestores.

Quadro 6 - Critérios de seleção CES/MT.

Fonte: elaboração própria.

O CES de Mato Grosso do Sul foi instituído pelo Decreto $\mathrm{n}^{\circ}$ 1055/1988, com alteração pelo Decreto $n^{\circ}$ 1595/1989, e regulamentado por regimento interno. De acordo com normativo interno, o conselho é composto pelo Secretário de Saúde - presidente nato do CES - 
e mais 24 membros seguindo o critério da paridade. Foram entrevistados oito membros conforme quadro 07.

\begin{tabular}{|lccc|}
\hline \multicolumn{1}{|c}{ Critério de Seleção } & $\begin{array}{c}\text { (\%) Resolução } \\
\mathbf{4 5 3 / 2 0 1 2}\end{array}$ & $\begin{array}{c}\text { Quantidade } \\
\text { Conselheiros } \\
\text { CES/MT }\end{array}$ \\
\hline $\begin{array}{l}\text { Representantes de entidades, instituições } \\
\text { movimentos representativos de usuários } \\
\begin{array}{l}\text { Entidades representativas de trabalhadores da área } \\
\text { da saúde }\end{array}\end{array}$ & $50 \%$ & 4 \\
$\begin{array}{l}\text { Governo e Entidades representativas de } \\
\text { prestadores de serviços de saúde }(*)\end{array}$ & $25 \%$ & 2 \\
\hline
\end{tabular}

(*) Dois gestores.

Quadro 7 - Critérios de seleção CES/MS.

Fonte: elaboração própria.

\subsubsection{Materiais analisados na avaliação da amplitude de participação social dos CES}

A avaliação da amplitude de participação social utilizou as atas plenárias disponibilizadas pelos Conselhos de Saúde. Para este quesito foram analisadas 207 atas das reuniões plenárias, com média de seis páginas cada, totalizando 1.242 páginas. Com respeitos às entrevistas realizadas com os conselheiros de saúde foram transcritas e analisadas 27 entrevistas, totalizando 86 páginas - média de três cada.

\subsection{Prestações de Contas e os Aspectos Qualitativos da Informação}

3.2.1 Análise documental como ferramenta de análise dos relatórios

O dicionário Houaiss conceitua, inicialmente, documento como uma declaração escrita, reconhecida e que pode servir como prova de um fato ou acontecimento; em outra perspectiva, como qualquer objeto que possa vir a comprovar, elucidar ou registrar um fato (HOUAISS, 2008). No caso em questão, as prestações de contas encaminhadas pelas Secretarias Estaduais de Saúde do Centro Oeste podem ser entendidas como "declarações escritas" que têm como propósito elucidar fatos atinentes às ações de saúde pública dos Estados.

Ainda nesse contexto, a análise documental pode ser entendida como algo que permite acrescentar a dimensão do tempo e das circunstâncias à compreensão social de determinados fatores. Logo, a análise do documento possibilita a realização de um corte 
longitudinal - intervalo de tempo específico - que pode favorecer a observação do processo de maturação de grupos, conceitos, práticas e comportamentos (POUPART et al., 2008).

Portanto, ao considerar que o CES, responsável pela apreciação das prestações de contas, é uma instância que visa promover a participação da sociedade na definição e execução de políticas públicas de saúde, é possível aceitar a ideia de que o controle social pode ser exercido, também, por meio das "declarações escritas" - entendidas aqui como documentos que prestam contas. Assim sendo, a análise documental se justifica de forma adequada.

3.2.2 Instrumento de pesquisa - Prestações de Contas e os aspectos qualitativos da Informação

O controle da sociedade sobre o Estado, como visto anteriormente, pode ser exercido por meio do acompanhamento da alocação de recursos destinados ao Sistema Unificado de Saúde. Não obstante, o processo de verificação dos recursos alocados, juntamente com as práticas empregadas na área de saúde, se utiliza de um instrumento de accountability que tem por finalidade dar transparência às informações que são geradas pelos gestores de saúde pública de cada município (REZENDE, 2013).

Sob esse enfoque, o instrumento de pesquisa, desenvolvido por Gonçalves et al. (2010), e posteriormente validado por Rezende (2013), se propõe a analisar - com foco nos aspectos qualitativos da informação - os relatórios de prestações de contas encaminhados pelas Secretarias de Saúde aos Conselhos de Saúde. Ao abordar o instrumento de pesquisa é possível destacar as características qualitativas fundamentais e de melhoria - conforme item 2.3.3 - como elementos balizadores da análise dos relatórios de prestações de contas. A análise dessas dimensões utilizou-se de indicadores, propostos pelo instrumento, para descrever a qualidade dos referidos relatórios.

De acordo com as características qualitativas mencionadas na estrutura conceitual do CPC 00 (R1) (2010) - conforme itens 2.3.3.1 e 2.3.3.2 - o instrumento de pesquisa deveria conter as seguintes características: relevância, materialidade, representação fidedigna, comparabilidade, compreensibilidade e tempestividade. Nesse sentido, buscou-se a ampliação do instrumento de Gonçalves et al. (2010) que continha a relevância, materialidade e confiabilidade. Ao longo do desenvolvimento da pesquisa e acesso às informações dos conselhos verificou-se que a operacionalização das características qualitativas comparabilidade e compreensibilidade não se mostravam aderentes em termos de avaliação 
dos relatórios de prestação de contas. A justificativa para essa questão é que categorizar, por exemplo, clareza - uma das variáveis consideradas para compor a dimensão da compreensibilidade (conforme CPC 00 (R1), 2010) - dentro das prestações de contas seria inviável para o estudo, pois possuiria carga subjetiva. Com respeito à comparabilidade não foi possível desenvolver para este estudo uma categorização que se mostrasse adequada à avaliação das prestações de contas.

Por outro lado, é válido destacar que o indicador prudência, pertencente a dimensão da representação fidedigna, foi retirado da estrutura original apresentada por Gonçalves et al. (2010). A característica prudência (conservadorismo) foi retirada por ser inconsistente com a neutralidade. A argumentação do CPC 00 (R1) (2010, p. 7) é que "subavaliações de ativos e superavaliações de passivos, segundo os Boards mencionam nas bases para conclusões, com consequentes registros de desempenhos posteriores inflados, são incompatíveis com a informação que pretende ser neutra". Já o indicador antes abordado com oportunidade, relativo à dimensão da relevância, foi realocado na dimensão da tempestividade sob o nome de periodicidade. Isto se justifica pelas características da tempestividade estarem mais adequadas ao que foi proposto anteriormente.

Após a apresentação dos aspectos qualitativos da informação contábil e suas respectivas dimensões torna-se necessário, além de detalhar seus indicadores e variáveis, explicitar a sua devida adequação à realidade dos relatórios de prestações de contas encaminhadas ao CES (GONÇALVES et al., 2010). Ao operacionalizar este intento foram utilizados 11 indicadores e 13 variáveis com o objetivo de avaliar o nível de divulgação informacional dos relatórios - conforme aborda quadro 2. Além disso, utilizou-se a escala Likert para desenhar a avaliação das categorias teóricas (ver anexos B, C e D), a saber:

i) Restrita - a informação requerida não é divulgada;

ii) Baixa - a informação requerida não é divulgada, contudo, o gestor manifestou intenção em passar a divulgar;

iii) Média - o gestor divulga a informação requerida, mas não o faz de forma completa segundo os critérios estabelecidos no instrumento de evidenciação;

vi) Ampla - o gestor divulga a informação requerida de forma completa segundo os critérios estabelecidos no instrumento de evidenciação. 


\begin{tabular}{|c|c|c|c|}
\hline \multicolumn{4}{|c|}{ Características qualitativas fundamentais } \\
\hline \multicolumn{4}{|c|}{ Característica Qualitativa Fundamental (i) } \\
\hline \multicolumn{4}{|c|}{ Relevância } \\
\hline \multicolumn{4}{|c|}{ Indicadores } \\
\hline \multicolumn{2}{|c|}{ Valor preditivo } & \multicolumn{2}{|c|}{ Valor confirmativo } \\
\hline \multicolumn{4}{|c|}{ Variáveis } \\
\hline \multicolumn{2}{|c|}{ Prioridade para destinação de recursos financeiros } & \multicolumn{2}{|c|}{$\begin{array}{l}\text { Confronto dos resultados obtidos comas metas } \\
\text { estabelecidas para a área de saúde }\end{array}$} \\
\hline \multicolumn{4}{|c|}{ Materialiadade } \\
\hline \multicolumn{4}{|c|}{ Indicadores } \\
\hline Dados quantitativos & $\begin{array}{l}\text { Grau de itemização dos dados } \\
\text { quantitativos }\end{array}$ & $\begin{array}{l}\text { Relações entre a SES e o } \\
\text { Conselho de Saúde }\end{array}$ & $\begin{array}{c}\text { Planos e expectativas } \\
\text { relevantes da } \\
\text { administração }\end{array}$ \\
\hline \multicolumn{4}{|c|}{ Variáveis } \\
\hline $\begin{array}{c}\text { Evidenciação da aplicação dos recursos } \\
\text { financeiros }\end{array}$ & $\begin{array}{l}\text { Especificação da fonte dos recursos } \\
\text { financeiros }\end{array}$ & $\begin{array}{c}\text { Participação das decisões } \\
\text { do Conselho nas decisões } \\
\text { da Secretaria de Saúde }\end{array}$ & $\begin{array}{c}\text { Planos e expectativas } \\
\text { relevantes da } \\
\text { administração }\end{array}$ \\
\hline \multicolumn{4}{|c|}{ Característica Qualitativa Fundamental (ii) } \\
\hline \multicolumn{4}{|c|}{ Representação Fidedigna } \\
\hline \multicolumn{4}{|c|}{ Indicadores } \\
\hline Conteúdo & Valor descritível e mensurável & Neutralidade & Precisão \\
\hline \multicolumn{4}{|c|}{ Variáveis } \\
\hline $\begin{array}{c}\text { Divulgação de prioridades para destinação } \\
\text { de recursos financeiros }\end{array}$ & Retificações orçamentárias & $\begin{array}{l}\text { Previsão de recursos } \\
\text { compreendidos no PPA } \\
\text { para área de saúde }\end{array}$ & $\begin{array}{c}\text { Divulgação dos pontos } \\
\text { que necessitam de } \\
\text { melhorias }\end{array}$ \\
\hline \multicolumn{4}{|c|}{ Características Qualitativas de Melhoria } \\
\hline \multicolumn{4}{|c|}{ Tempestividade (i) } \\
\hline \multicolumn{4}{|c|}{ Indicador } \\
\hline \multicolumn{4}{|c|}{ Periodicidade } \\
\hline \multicolumn{4}{|c|}{ Variáveis } \\
\hline Periodicidade de disponib & ação dos relatórios & Disponibilidade do & latório em análise \\
\hline
\end{tabular}

Quadro 8 - Resumo esquemático do instrumento de pesquisa - Prestação de Contas.

Fonte: Gonçalves et al. (2010) adaptado.

\subsubsection{Dimensão da Relevância}

Incialmente, para considerar a relevância no âmbito das prestações de contas é preciso antes verificar a disponibilidade que a informação deve ter para influenciar na tomada de decisão no CES. Na hipótese da informação ser tempestiva é possível realizar predições e confirmações acerca do quadro da saúde pública. Seguindo essa linha considera-se que a 
dimensão da relevância possui dois indicadores para nortear a análise das prestações de contas: valor preditivo e valor confirmativo.

Para o FASB (1980) o valor preditivo é a qualidade da informação responsável por ajudar os usuários a prever da forma mais próxima da realidade o resultado de eventos do presente ou do passado. Dentro dessa ótica, Rezende (2013) ressalta que é função do CES deliberar sobre o estabelecimento de prioridades para que as metas da saúde sejam cumpridas. O autor afirma ainda que os recursos públicos destinados à saúde, constantes na Lei Orçamentária Anual (LOA), devem estar alinhados às prioridades, também, da Programação Anual de Saúde (PAS), e que, por conta disso, cabe ao conselho avaliar as prestações de contas para realizar o controle das metas. Para tanto, foi estabelecida a variável "recursos financeiros previstos na proposta/lei orçamentária" com o propósito de avaliar se os recursos foram aplicados conforme o previsto na LOA e na PAS.

Para Gonçalves et al. (2010) a finalidade de se utilizar esta variável é avaliar se os recursos financeiros previstos para área da saúde para o exercício subsequente foram evidenciados por programas de governo, por ações do governo e/ou por fontes de recursos. As referidas análises reforçam o caráter preditivo das informações contidas em prestações de contas no sentido de tomar decisões. O outro indicador se refere ao Valor Confirmativo - também conhecido por valor como Feedback (PAULO, 2002). Este refere-se à correção ou confirmação das expectativas do passado, o que também pode ser importante para o processo decisório (HENDRIKSEN; VAN BREDA, 2011). Para dar forma ao indicador valor conformativo utilizou-se a variável 'confronto dos resultados obtidos com as metas estabelecidas para área da saúde'.

A referida variável objetiva evidenciar quais foram os resultados obtidos a partir dos recursos disponibilizados para área da saúde, ou seja, se as metas traçadas, inclusive na PAS e no Plano Estadual de Saúde (PES), foram atingidas (GONÇALVES et al. 2010). De acordo com Rezende (2013) quando as informações permitem identificar o atingimento de metas é possível propor ações corretivas quando estas não estão de acordo com o previsto, ou seja, viabilizando melhorias na saúde pública de um município, por exemplo. 


\subsection{Subdimensão da Materialidade}

De acordo com IASB (2001) a Materialidade afeta a Relevância. O órgão normativo justifica a questão argumentando que a materialidade pode ser influenciada por erros ou pelo tamanho (quanto ao valor) de determinados registros contábeis. Logo, entende-se que considerar, por exemplo, uma informação contida em uma prestação de contas como relevante requer que a mesma seja material. Nesse sentido, Gonçalves et al. (2010) consideram que a materialidade para as prestações de contas da saúde tem como foco identificar se os objetivos, metas e recursos aplicados são consistentes com o que foi estabelecido previamente, ou seja, a materialização se dá com o cumprimento desta finalidade. Para efeito de análise desta característica nos relatórios foram utilizados os seguintes indicadores, quais sejam: 'dados quantitativos'; o 'grau de itemização de dados quantitativos '; 'relações entre a SES e o CES'; e os 'planos e expectativas da administração'.

O primeiro indicador - dados quantitativos - toma como referência aquilo que foi preconizado na PAS e na LOA, pois para verificar se os recursos foram aplicados em consonância com os referidos instrumentos é preciso que este confronto esteja presente no relatório de prestação de contas. Para tanto, foi utilizada a variável 'evidenciação da aplicação de recursos financeiros' para avaliar se os programas e ações destinadas à saúde foram cumpridos (REZENDE, 2013).

O segundo indicador - grau de itemização dos dados quantitativos - se refere à evidenciação das fontes de recursos, inseridas no PPA e na LOA, que financiam o SUS. O intuito é verificar a origem dos recursos financeiros e sua respectiva alocação conforme instrumentos orçamentários citados. A variável 'especificação da fonte dos recursos financeiros' tem como objetivo verificar se as fontes de recursos foram apresentadas na prestação de contas.

Já o indicador 'relações entre a SES e o Conselho de Saúde' avalia se no relatório de prestações contas existem informações que remetam ao cumprimento, por parte da SES, de orientações repassadas pelo Conselho quando da elaboração de seus pareceres (GONÇALVES et al., 2010). Então, utilizou-se a variável 'participação do Conselho nas decisões da Secretaria de Saúde' com intuito de atender ao propósito de evidenciar a relação em epígrafe. 
De acordo com Rezende (2013) é dever dos conselheiros verificar o cumprimento do que foi traçado no Plano da Saúde, no caso desta pesquisa o Plano Estadual de Saúde (PES). O autor destaca ainda que o referido plano está relacionado ao PPA. Por oportuno, é valido enfatizar que existem problemas de articulação entre os instrumentos que norteiam a gestão da saúde pública (VIEIRA, 2009). Por conta disso, faz-se necessária a verificação dos planos e expectativas da administração, último indicador da materialidade, para avaliar se o gestor da saúde busca evidenciar o estabelecimento de metas e objetivos da gestão do SUS para o exercício subsequente, em face das diretrizes estabelecidas no PPA (REZENDE, 2013). A variável estabelecida para esta finalidade foi 'objetivos e metas para o exercício subsequente'.

\subsubsection{Dimensão da Representação Fidedigna}

De acordo com Paulo (2002) as estruturas conceituais apresentadas por FASB e IASB consideram que para determinada informação ser considerada confiável ela precisa representar fielmente aquilo que se pretende representar, além de possuir neutralidade. Por outro lado, a confiabilidade é alcançada quando a informação não possui erros materiais ou vieses relevantes (NIYAMA; SILVA, 2011), pois a presença de informações deste tipo podem comprometer as demonstrações contábeis - neste contexto: relatórios de prestações de contas.

Portanto, existem características adequadas à avaliação do que seria a Representação Fidedigna da informação para as informações dos relatórios da saúde. Dessa forma, para nortear a análise dos relatórios, no tocante a esta dimensão, foram utilizados quatro indicadores, a saber: 'conteúdo', 'valor descritível e mensurável', 'neutralidade' e 'precisão' (GONÇALVES et al., 2010). A primeira variável 'divulgação das prioridades para destinação de recursos financeiros' visa identificar as prioridades estabelecidas no tocante às metas traçadas, na hipótese de ocorrerem retificações orçamentárias.

Diante dessa situação, busca-se analisar se a SES estabeleceu prioridades relativas às metas traçadas anteriormente (GONÇALVES et al., 2010). Logo, espera-se verificar evidências da referida conduta nos relatórios, utilizando a variável mencionada. Para Rezende (2013) o gestor da saúde pode ser surpreendido com necessidades de gastos não previstos nos instrumentos de destinação de recursos, o que realça a ideia de priorizar a destinação de determinados recursos dado que não será possível, em determinados momentos, cumprir todas as metas. 
Já a variável 'evidenciação das retificações orçamentárias' se encaixa na discussão no momento em que os recursos passam a ser insuficientes para determinadas demandas sociais. Nesse caso, o gestor da saúde precisa pedir autorização para o legislativo no sentido de alterar o orçamento por meio de suplementações e/ou retificações orçamentárias para cobrir determinadas despesas (REZENDE, 2013). Isso se coaduna com a questão das prioridades para destinação de recursos, dado que se tira dotação de determinada finalidade para inserir em outra mais prioritária.

Por outro lado, o indicador valor 'descritível e mensurável' objetiva verificar qual é o planejamento adotado pela SES no sentido de dar cumprimento às metas estabelecidas no PPA (GONÇALVES et al., 2010). Para tanto, utilizou-se a variável 'previsão de recursos para os exercícios compreendidos no PPA para a área de saúde' que tem como finalidade verificar a evidenciação de recursos financeiros a serem aplicados de acordo com os programas traçados no PPA do Estado, considerando, ainda, o PES (REZENDE, 2013). O importante é saber se existem recursos suficientes para cumprir as metas contidas no PPA.

Ademais, destaca-se a importância da informação ser neutra dentro das prestações de contas, pois a parcialidade ou o viés dos gestores da saúde podem influenciar as decisões tomadas pelo CES, além de comprometer a confiabilidade do processo decisório. De acordo com Rezende (2013) o ponto relevante dessa abordagem é a evidenciação por parte dos gestores da saúde de fragilidades e/ou dificuldades encontradas na administração dos recursos destinados a esta área. Portanto, a variável utilizada para este propósito é a 'divulgação dos pontos que necessitam de melhorias', cuja proposta é confrontar as metas estabelecidas com os resultados alcançados para encontrar pontos que precisam de melhorias - citando-os no relatório (REZENDE, 2013).

Por fim, o indicador da precisão toma como referência a legislação imposta para a área da saúde no sentido de verificar se as demandas da comunidade foram atendidas em consonância com os normativos estabelecidos. Segundo Rezende (2013), é dever do conselheiro de saúde verificar se a omissão de informações é feita de forma deliberada pelos gestores, o que, de fato, pode prejudicar a qualidade das informações prestadas. É com esse pano de fundo que se espera que as prestações de contas sejam precisas em atender aquilo que foi preconizado na legislação pertinente. À exemplo dos normativos, a resolução CNS 453/2013 - como dito anteriormente no item 2.3.2 - estabelece que os relatórios de prestação de contas devem conter o andamento da agenda de saúde pactuada; relatório de gestão; montante, fonte e forma de 
aplicação dos recursos aplicados; auditorias iniciadas e concluídas no período; oferta e produção de serviços na rede assistencial. Em face dessas questões, utilizou-se a varável 'evidenciação do conteúdo legal' para avaliar a precisão dos relatórios de prestação contas em atender aos normativos pertinentes.

\subsubsection{Dimensão da Tempestividade}

A palavra tempestividade, para o contexto contábil de características qualitativas da informação, guarda similaridade com o termo oportunidade. Além disso, como dito anteriormente, para que a informação possa ser considera relevante é preciso que seja tempestiva/oportuna. Ao considerar o CES e a avaliação das prestações de contas entende-se que a informação precisa estar disponível no momento em que o pleno está deliberando ou, até mesmo, quando as comissões estão elaborando seus pareceres para fundamentar as decisões tomadas nas plenárias. Diante disso, foram definidas duas variáveis para avaliar a tempestividade das informações inseridas nas prestações de contas, quais sejam: 'periodicidade de disponibilização de relatórios' e 'disponibilização do relatório em análise'.

A primeira variável verifica se nos relatórios de prestação de contas foi evidenciada a data de divulgação do próximo relatório de prestação de contas a ser entregue pela SES, atualmente feito de forma quadrimestral (GONÇALVES et al. 2010). Já a segunda variável 'disponibilização do relatório em análise' faz referência à evidenciação do momento em que o relatório de prestação de contas foi disponibilizado (GONÇALVES et al. 2010), ou seja, quando foi encaminhado para apreciação do CES. Um exemplo simples do propósito da segunda variável seria a análise de relatório do primeiro quadrimestre de 2014 disponibilizado pela SES/GO em agosto - quando na verdade deveria ter apresentado ao CES em maio. Nesse caso, determinadas informações perderiam sua capacidade de informar os conselheiros de saúde oportunamente sobre algum programa de saúde ou ação especifica. Face ao exposto sobre tempestividade, cumpre destacar os prazos de entrega dos relatórios analisados neste trabalho, os quadrimestrais e anuais. 


\begin{tabular}{|c|c|c|}
\hline Relatório & Dispositivo Legal & Prazos \\
\hline Relatórios Quadrimestrais & Art. $41 \mathrm{da} \mathrm{LC} \mathrm{n} 141 / 2012$ & Maio - Setembro - Fevereiro \\
\hline Relatório Anual de Gestão & $\S 1^{\circ}$ do art. 36 da LC n \\
$141 / 2012$ & Até 30 de março de cada ano. \\
\hline
\end{tabular}

Quadro 9 - Prazos de encaminhamento dos relatórios aos CES.

Fonte: Lei Complementar no 141/2012; Rezende (2013).

\subsubsection{Materiais analisados na avaliação da qualidade dos relatórios das SES}

A avaliação das prestações de contas das Secretarias Estaduais de Saúde teve como base de 30 relatórios de prestação de contas (no período de 2011 a 2013) - 10 relatórios por Secretaria. A média de páginas por relatório chegou a 63 páginas, totalizando algo em torno de 1900 páginas nas três SES. Destaca-se, ainda, que para cada relatório foram analisadas 13 variáveis, totalizando 130 aspectos verificados em cada Secretaria. Ao total foram 390 aspectos analisados. Adicionalmente foram analisados os Relatórios Anuais de Gestão e seus respectivos pareceres para o mesmo período (2011-2013), perfazendo um total de 9 RAGs - com média de 40 páginas cada. Por fim, também foram consultados os Planos Estaduais de Saúde e os PPAs dos Estados.

\subsubsection{Análise e Classificação das Variáveis da Qualidade da Informação}

Por oportuno, salienta-se, em relação aos relatórios de prestações de contas, a existência de três pacotes de informação que podem ou não ser divulgados nos relatórios quadrimestrais e anuais. O primeiro deles foi denominado "Pacote Obrigatório" e está relacionado às variáveis que atendem às exigências legais contidas na Resolução do CNS 453/2012 e na Lei Complementar 141/2012. O segundo - "Pacote Decorrente do Obrigatório" - se refere a variáveis que não se enquadram como obrigatórias e nem voluntárias, mas que decorrem do conjunto obrigatório, ou seja, figuram como possíveis desdobramentos. Já o terceiro - "Pacote Voluntário" - se refere àquelas informações que podem ser divulgadas nos relatórios em virtude da ação voluntária do gestor em prestar contas dos atos de sua gestão.

Adicionalmente, é valido mencionar que apesar das recomendações contidas na legislação (Resolução do CNS 453/2012 e na Lei Complementar 141/2012) não há padronização dos relatórios de prestação de contas, ou seja, como eles deveriam ser apresentados. Em virtude da não padronização buscou-se para esta pesquisa tipificar as 
informações contidas nos relatórios por meio das variáveis da qualidade da informação já previamente discutidas como obrigatórias, decorrente das obrigatórias e voluntárias.

O "Pacote Obrigatório" é composto das seguintes variáveis: 03 - evidenciação da aplicação dos recursos financeiros, 04 - especificação da fonte dos recursos financeiros, 09 previsão de recursos para os exercícios compreendidos no PPA para a área da saúde, 11 evidenciação do conteúdo legal e Variável 13 - Disponibilização do relatório em análise (cinco variáveis - representando 38\% do total de variáveis). Todavia, existem variáveis decorrentes das obrigações legais - Pacote Decorrente do Obrigatório, no caso: 02 - confronto dos resultados com as metas estabelecidas para área de saúde; e 08 - evidenciação das retificações orçamentárias (15\% do total de variáveis). Já o "Pacote Voluntário" faz referência às demais variáveis: 01 - recursos previstos na proposta/lei orçamentária, 05 - participação do Conselho nas decisões da Secretaria de Saúde, 06 - objetivos e metas para o exercício subsequente?, 07 - divulgação das prioridades para destinação dos recursos financeiros, 10 - divulgação dos pontos que necessitam de melhorias; e 12 - periodicidade de disponibilização dos relatórios (seis variáveis - representando $46 \%$ do total de variáveis).

Em relação ao resultado espera-se que quanto maior for a amplitude de participação social, maior será nível de divulgação de informações. Portanto, a qualidade tenderia a ser maior, sobretudo com respeito às variáveis de divulgação voluntária, dado que este tipo de informação representa, por exemplo, a neutralidade do gestor em divulgar os pontos que necessitam de melhorias na área da saúde.

\subsection{Limitações da Pesquisa}

Em relação às limitações da pesquisa cumpre-se salientar, incialmente em relação à avaliação da tendência de amplitude de participação que as atas não reuniões plenárias foram disponibilizadas de modo a compreender o período de criação dos Conselhos até a presente data. Isso motivou a realização de entrevistas com o conselheiro mais antigo de cada CES. Outro ponto é a questão da análise pontual da dimensão histórica da amplitude de participação. Ocorre que avaliar toda a história do CES não seria possível somente com as atas plenárias, pelo fato das mesmas não conterem todo o histórico necessário. Além disso, as entrevistas só puderam ser realizadas de forma pontual, pois tratavam-se de diferentes Estados. Por outro lado, mesmo que o período de pesquisa de campo fosse estendido, não seria possível entrevistar todos os conselheiros que fizeram parte da história dos CES. 
Ainda no que se refere às entrevistas com os conselheiros cumpre-se mencionar que não foram coletados dados mais completos acerca do perfil destes.

Com respeito aos relatórios de prestações de contas não foi possível avaliar o ano de 2014 por conta destes não terem sido avaliados pelos Conselhos Estaduais de Saúde. Logo, não houve até a conclusão desta pesquisa a emissão de parecer acerca das contas da gestão da saúde nos Estados de Goiás e Mato Grosso. Dessa forma, se excluiu o ano de 2014 da análise. 


\section{ANÁLISE DOS RESULTADOS}

Esta seção realiza a análise dos resultados acerca da amplitude de participação social dos Conselhos Estaduais de Saúde e da qualidade da informação dos relatórios de prestação de contas elaborados pelas Secretarias Estaduais de Saúde. Nesse sentido, existem dois blocos iniciais com a apresentação dos resultados de forma separada, b0em como uma discussão dos mesmos - logo em seguida. Por fim, foi inserido um bloco para discutir a qualidade da informação em face amplitude de participação social.

Logo, o objetivo inicial foi avaliar a tendência da amplitude da participação social de cada Conselho Estadual de Saúde da Região Centro Oeste, a partir das duas dimensões citadas anteriormente - histórica e amplitude de participação social. A primeira delas trabalha o indicador Implantação e Departamentalização do CES de acordo com a sedimentação histórica (GRAMSCI, 1981). Já a dimensão da amplitude participação social possui uma subdimensão chamada tradução de demandas e tem a finalidade, por meio dos indicadores Avaliação de Necessidades, Liderança e Mobilização de Recursos, de categorizar o CES quanto a sua participação social - a partir da visão dos conselheiros.

Já em relação a qualidade da informação das prestações de contas das Secretarias Estaduais da Região Centro Oeste têm-se como foco avaliar as dimensões da relevância, representação fidedigna e tempestividade das informações contidas nos referidos relatórios. $\mathrm{Na}$ última etapa busca-se analisar se a participação social do CES possibilita maior qualidade da informação dos relatórios, além descrever, de maneira breve, o ambiente de controle social que está relacionado a esse cenário

\subsection{Amplitude de Participação da Comunidade nos Conselhos Estaduais de Saúde da Região Centro Oeste}

\subsubsection{Amplitude de Participação Social da Comunidade no CES/GO}

A amplitude de participação social trata de uma dimensão que avalia a tendência de participação social nos conselhos e é composta por duas subdimensões. A primeira delas é a dimensão histórica que verifica questões relacionadas ao processo de implantação $e$ departamentalização do Conselho, ou seja, como este se organiza em novas estruturas, como integra novos temas de saúde e que mudanças ocorreram desde a sua implantação (SILVA, 
1999). A segunda subdimensão, tradução de demandas, na visão de Silva (2005), busca avaliar as demandas da sociedade, inclusive como são recebidas e avaliadas pelo Conselho, bem como o tipo de liderança que figura neste cenário, além de verificar, também, a mobilização de recursos para atender as referidas demandas.

\subsubsection{Implantação e Departamentalização (Dimensão Histórica)}

A avaliação da dimensão histórica no Conselho Estadual de Saúde de Goiás se utilizou das entrevistas com os conselheiros de saúde para verificar como o CES foi implantado. A partir daí foi constatado que apenas três dos oito conselheiros entrevistados detinham conhecimento maior do momento da implantação ou vivenciaram alguma experiência que remetia àquela fase. $\mathrm{O}$ tempo de experiência no exercício das atribuições, em média, dos conselheiros entrevistados foi de 4,5 anos. Outro aspecto a ser destacado é a questão das atas plenárias só estarem disponíveis para os anos de 2005 a 2006 e 2013 a 2014, contrariando a legislação vigente e o próprio regimento. As atas são documentos importantes para que se possa entender como ocorre a atuação do Conselho, inclusive como isso se deu ao longo do tempo. Somados os aspectos apresentados levantou-se a necessidade de entrevistar um conselheiro, indicado pelo Conselho, que detivesse maior conhecimento da perspectiva histórica da implantação e departamentalização, para que, então, fosse possível obter maiores informações sobre este indicador.

A implantação do CES/GO, na visão de seis dos oito conselheiros, ocorreu em virtude de imposição legal, mais especificamente por meio de decreto do governador. Nessa linha, o conselheiro 09 (segmento usuários) - mais antigo indicado pela Secretaria Executiva do Conselho $^{26}$ - informou que o Conselho foi criado em 1992, via decreto $\mathrm{n}^{\mathrm{o}} 3887 / 1992$, e em 2003 houve um novo decreto $\mathrm{n}^{\mathrm{o}} 5.727 / 2003$ alterando algumas atribuições. Ainda segundo o conselheiro não houve maior participação da população na criação do conselho e, por conta disso, somente após este processo as entidades começaram a tomar seus lugares como atores sociais. Na visão do conselheiro 05 (segmento usuários) "na década de 80 quando foi feita uma

\footnotetext{
${ }^{26}$ Compostas por conselheiros dos quatro segmentos (usuários, trabalhadores, prestadores de serviço e governo). Regimento interno, Art. 32, parágrafo único: A Secretária Executiva é um órgão vinculado ao Gabinete do Secretário de Estado de Saúde de Goiás e a Mesa Diretora do Conselho Estadual de saúde de Goiás, tendo por finalidade a promoção do necessário apoio técnico-administrativo ao Conselho e suas Comissões e Grupos de Trabalho.
} 
primeira reunião de pessoas, a oitava conferência foi um diferencial, pois nela ficou tudo escrito, o que tinha que ser feito, o real papel dos Conselhos". Nota-se que a única menção a discussões sobre criação dos Conselhos com influência da sociedade se deu em virtude da $8^{\text {a }}$ Conferência Nacional de Saúde. Logo, mesmo que tenha havido envolvimento de representantes do Estado de Goiás isso não representa envolvimento da sociedade em instigar e buscar a criação do Conselho de Saúde para aquele Estado. Com isso a concepção da imposição legal fica mais aparente.

Em relação às entidades eleitas para compor o Conselho é possível dizer que não chegaram a obter participação ativa nas discussões dos CES, portanto, não foram plenamente ativas, ao longo do tempo, fato que ocorreu de forma mais acentuada somente nos últimos mandatos do CES. O regimento do Conselho estabelecia que as entidades deveriam ser eleitas democraticamente, bem como integrar as discussões do pleno no sentido de fomentar a cooperação entre as próprias entidades e instituições da área de saúde - art. 3, inciso XXII. Com respeito aos primeiros 32 conselheiros foi informado que estes foram eleitos formalmente dentro de uma conferência de saúde, diferentemente do processo que é realizado nos dias de hoje eleição das entidades em uma plenária do Conselho Estadual de Saúde.

Adicionalmente, o conselheiro 09 (segmento usuários) argumentou que a eleição de conselheiros nem sempre ocorreu de maneira paritária, estando, portanto, em desacordo com a legislação em determinados momentos. Em relação a participação das entidades representativas nas deliberações do Conselho apenas algumas, cerca de 10, são mais participativas e, de forma geral, o CES ainda precisa evoluir. Ainda com foco nas deliberações cabe enfatizar que ao longo da história da história do Conselho houve influência político partidária, principalmente pelos sindicatos, atuando muitas vezes em benefício próprio. Diante desse cenário a população, de maneira geral, não se reconhece como parte integrante do processo de gestão da saúde. No sentido de fundamentar as referidas informações são apresentados alguns trechos da fala do conselheiro em questão (mais antigo - 09 - usuário):

Como ocorreu a implantação do conselho? De quem partiu a iniciativa? Houve envolvimento da população? Em 1992, o CES foi criado por um decreto do governador e, 2003, ele foi reafirmado por outro decreto. O Goiás é um dos poucos estados que ainda tem um conselho homologado por decreto, a maioria já tem leis. Porque é obrigação legal. Não basta a Lei 8.142 que é federal, mas cada Estado, Município tem que criar o seu conselho por lei, não pode ser por decreto ou portaria. No nosso caso ainda estamos devendo para a sociedade. Mas o Conselho do Estado de Goiás foi imposto, assim como todos os conselhos a partir da criação da Lei 8.142. 
No início eram 32 conselheiros, que foram escolhidos por uma eleição dentro de uma conferência de saúde. Hoje, a gente já não usa mais esse modo de conferência, fazemos a eleição das entidades em uma plenária de eleição que é voltada só para o foco da eleição das entidades. (Grifo referente a pergunta do pesquisador)

E em relação aos segmentos se deu de maneira paritária, $50 \%$ de usuário, $25 \%$ governo e prestadores e $\mathbf{2 5 \%}$ trabalhadores? Sim em algum momento esteve fora, inclusive até hoje. Em 2012 foi motivo de um acórdão do Ministério Público da União exigindo do Ministério da Saúde que o conselho que não estiver devidamente paritário que o Município e Estado perca verbas. A questão da paridade é bastante maquiada, se não ficarmos bastante atentos cometemos erros. (Grifo referente a pergunta do pesquisador)

Houve participação da população ou de entidades? Na implantação não. Mas após a Constituição dar esta abertura as comunidades foram buscando seus espaços. (Grifo referente a pergunta do pesquisador)

Pode-se dizer que hoje, nós temos algumas instituições que participam mais dos conselhos, principalmente, da área do trabalhador, os sindicatos são os mais participativos dentro dos conselhos.

Como se deu a participação das entidades representativas nas deliberações do Conselho ao longo do tempo? No início do conselho a participação das entidades era mais tímida. Quando o conselho tem entidades mais participativas ele é mais atuante. O senhor considera que isto hoje configura no Conselho Estadual de Goiás? Nem tanto. Eu considero o Conselho de Goiás muito aquém do que deveria. Percebo que o conselho está muito governista, perdeu a cara de controle social. (Grifo referente a pergunta do pesquisador)

Na sua visão qual o grau da influência político partidária? Nos dois segmentos de trabalhadores e gestores existem em alto grau. Tanto no início quanto hoje. Mas a consciência do conselheiro mudou, o que dá uma contrabalanceada nisso. (Grifo referente a pergunta do pesquisador)

A comunidade se reconhece como parte integrante do processo de gestão da saúde? Não, não consegue. E quando buscamos este apoio percebemos que as pessoas têm muito medo. Por exemplo, estamos buscando uma garantia de $10 \%$ do PIB bruto da União para a saúde a nível nacional, fomos buscar assinaturas para o abaixo-assinado e as pessoas falam que não vão assinar por que tem medo de perderem o emprego porque foi uma pessoa conhecida que arrumou para ele. No início não aconteceu e nem agora. As entidades têm que ter a consciência que a cadeira delas não é só em momento de eleição, precisa participar mais. (Grifo referente a pergunta do pesquisador)

Após o relato da forma como ocorreu a implantação do conselho cumpre-se destacar alguns pontos. Inicialmente a afirmação levantada pelo conselheiro mais antigo, no tocante à imposição legal, para alguns conselhos do Brasil. Sabe-se que existem experiências de Conselhos com criação anterior a 1990, inclusive de forma voluntária ${ }^{27}$. Além disso, vale citar a criação do CNS que ocorreu em 1937 - lei 378, também por incentivo da via voluntária. Em relação à estruturação, Gonçalves, Gonçalves e Weffort (2012) consideram que a

${ }^{27}$ O Conselho Municipal de Saúde de Porto Alegre, por exemplo, foi implantado anterior mente à legislação de 1990 (8.080/1990 e 8.142/1992). Para maiores informações sobre a criação do CNS ver: < http://www.conselho.saude.gov.br/apresentacao/historia.htm >. 
departamentalização representa a forma como o Conselho se organiza em estruturas diferentes com intuito de integrar temas de saúde que vão surgindo de acordo com as necessidades da população. Diante disso, os conselheiros afirmam que foram criadas comissões, inclusive transitórias, para atender às demandas provenientes das necessidades da sociedade, ou pelo menos parte delas. A partir do exposto em relação à organização das comissões foi formulada a categoria teórica intermediária "criação de comissões transitórias".

No entanto, o que fica claro na argumentação dos mesmos é que as comissões não foram plenamente ativas ao longo do tempo e ainda enfrentam dificuldades para entregar um trabalho positivo, de forma que se possa realmente subsidiar o processo decisório do CES. Sob este prisma, o conselheiro 04 (segmento prestadores de serviço) argumenta que "ao mesmo tempo em que as nossas comissões estão desmobilizadas, elas estão sendo articuladas para funcionar. Nem todas estão funcionando como deveriam.”. Por outro lado, o conselheiro 05 (segmento usuários) afirma:

a gente procura criar estas comissões, inclusive, já tem algumas funcionando no conselho, funcionam bem. Estamos cada vez mais aconselhando as entidades a mandar pessoas para que possam agregar às comissões. Temos feito um trabalho para que as comissões possam vir a funcionar.

$\mathrm{Na}$ fala dos dois conselheiros fica clara a existência de problemas no desenvolvimento dos trabalhos das comissões criadas, possivelmente motivada pela falta de capacidade de alguns conselheiros agregarem nas discussões. Por outro lado, vale destacar um outro fator levantado pela conselheira 02 (segmento usuários):

\footnotetext{
Quando se fala em trabalho voluntário temos uma dificuldade muito grande na participação efetiva das comissões. Nosso maior objetivo é fazer estas comissões funcionarem. Hoje, nós trabalhamos a questão do regimento no próprio conselho, criamos um regulamento interno administrativo da diretoria executiva - que antes não existia tal diretoria -, temos o apoio técnico da diretoria executiva que está composta de advogados e pessoas gabaritadas que fornecem suporte e apoio às comissões. Isso auxilia muito as comissões. Uma comissão que tem muito peso na questão do trabalho no conselho é a prestação de contas, a Comissão de Orçamento e Financiamento da Saúde (COFIN). Antes não tínhamos esse apoio técnico para poder trabalhar nesta comissão.
}

Em face do exposto pela conselheira é possível verificar que existe uma preocupação com respeito a efetiva participação de conselheiros nas comissões. Isso pode, eventualmente, acarretar problemas no que se refere à fundamentação de pareceres para processo deliberativo 
do CES, pois para sua consecução é preciso que os conselheiros participem dos trabalhos, inclusive agregando para sua devida formulação. Contudo, é possível notar também que a atual composição do Conselho tem buscado estruturar melhor suas comissões e já possui exemplos de comissões que estão funcionando. Não obstante, vale mencionar que as comissões são flexíveis para captar novas demandas. Isto fica claro na fala do conselheiro 05 (segmento usuários) "sim considero super flexíveis. Inclusive sou coordenador de duas delas e nestas comissões somos abertos a comunidade, às entidades e a quem quiser vir participar da comissão". Apesar da fala do conselheiro apresentar abertura para entidades de fora do conselho não houve nenhum relato indicando um exemplo de envolvimento das mesmas. Além disso, também não foram apresentadas soluções, tampouco implementadas no sentido de promover a integração com atores externos.

Ademais, por conta da falta de agilidade das comissões e dos entraves elencados muitas vezes são criados grupos de trabalho ${ }^{28}$ (GTs) com intuito de agilizar o processo de deliberação. A partir do exposto em relação aos grupos de trabalho foi formulada a categoria teórica intermediária "criação de GTs". Para conselheira 04 (segmento usuários) "foram constituídos alguns grupos de trabalho que estão conseguindo trabalhar com mais fluência" do que as comissões. O conselheiro 09 (segmento usuários - mais antigo) explica que:

O mais correto é o GT porque ele não precisa ser um grupo grande. Qual a efetividade disso na perspectiva histórica do Conselho? Foram criadas muitas comissões transitórias e GTs desde a criação? Sim, principalmente o GT. As pessoas gostam mais do GT porque apenas três pessoas podem deliberar. Por exemplo, a questão da Dengue, cria-se um GT para fazer um estudo sobre a Dengue. A criação de GTs é mais frequente que a criação de comissões? No início criava-se mais comissões transitórias, com o passar do tempo as pessoas foram percebendo que o GT é mais objetivo. Então hoje se cria mais o GT. (Grifo referente a pergunta do pesquisador)

Por fim, destaca-se que as mudanças ocorridas na estrutura do CES beneficiaram os profissionais de saúde ou toda a comunidade. Nesse sentido, todos os conselheiros entrevistados afirmaram que as mudanças beneficiaram a comunidade e os trabalhadores da saúde. Em alguns casos o que foi dito, além disso, estava relacionado a interpretação, por parte dos conselheiros,

\footnotetext{
${ }^{28}$ Conforme Regimento Interno do CES/GO, Seção III, art. 26, inciso II, os grupos de trabalho podem atuar com até cinco membros efetivos. Em relação às atribuições o $\S 1^{\circ}$ do inciso II versa que "As comissões e Grupos de Trabalho serão dirigidas por um Coordenador eleito pelo Plenário do Conselho que coordenará os trabalhos, com direito a voz e voto, sendo que, no caso das comissões permanentes, obrigadas em lei, a coordenação será exercida por um Conselheiro aprovado pelo Plenário".
} 
de que as mudanças não ocorriam necessariamente como eles desejavam, mas, ainda sim, produziam melhorias. A fala da conselheira 04 (prestadora de serviço) pode traduzir um pouco a questão relativa a possibilidade das mudanças terem beneficiado a comunidade e os profissionais da saúde:

Eu acho que sim, porque quando vêm demandas tratam-se de política da farmácia, da saúde mental e outros pontos dos trabalhadores. Como eu te disse as lideranças oscilam. Então, eu vejo que o grupo dos trabalhadores é forte. Tanto que uma das comissões que tem trabalho de ponta é a de saúde do trabalhador. Já houve plenária de saúde do trabalhador em que foram decididas coisas importantes para eles. Em relação a comunidade também acredito que sim, que a mesma é beneficiada. Ex: existem indicadores como a saúde da mulher, saúde neonatal, atendimento do SAMU que precisam ser melhor trabalhados. Por conta disso, são discutidos nas estruturas das comissões para trazer melhorias para a comunidade. Outro ponto é o caso das OS onde o conselho foi contra e nós estamos observando o impacto na comunidade. Talvez essa questão tenha que ser adequada às necessidades da sociedade.

Na esteira dessas evidências, encontram-se elementos para fundamentar a categorização da amplitude de participação relativa ao indicador implantação e departamentalização como restrita, ou seja, o CES foi imposto por legislação, mas passou a ter alguma atividade, por meio da criação de comissões e GTs. Todavia, sua departamentalização, em termos de comissões, ainda não apresenta característica de plenamente ativa - aspecto pertencente à tendência média - pelo fato de parte delas estarem desmobilizadas, necessitando, assim, de articulação para funcionar. De maneira geral as comissões ainda não cumprem plenamente a função de subsidiar o pleno. 


\begin{tabular}{|c|c|c|c|}
\hline $\bar{t}_{t}^{\star} \star_{t}^{\star}$ & & Categorias Empíricas & \\
\hline & Inicial & Intermediária & Final \\
\hline $\begin{array}{l}\text { Amplitude de Participação } \\
\text { Restrita: O CES foi imposto pelos } \\
\text { serviços de saúde, mas tem } \\
\text { alguma atividade. } \\
\text { Média: O CES foi imposto pelos } \\
\text { serviços de saúde, mas passou a } \\
\text { ser plenamente ativo. } \\
\text { Aberta: O CES coopera } \\
\text { ativamente com outras } \\
\text { organizações da comunidade. } \\
\text { Ampla: As organizações } \\
\text { comunitárias existentes } \\
\text { participaram da criação do CES. }\end{array}$ & 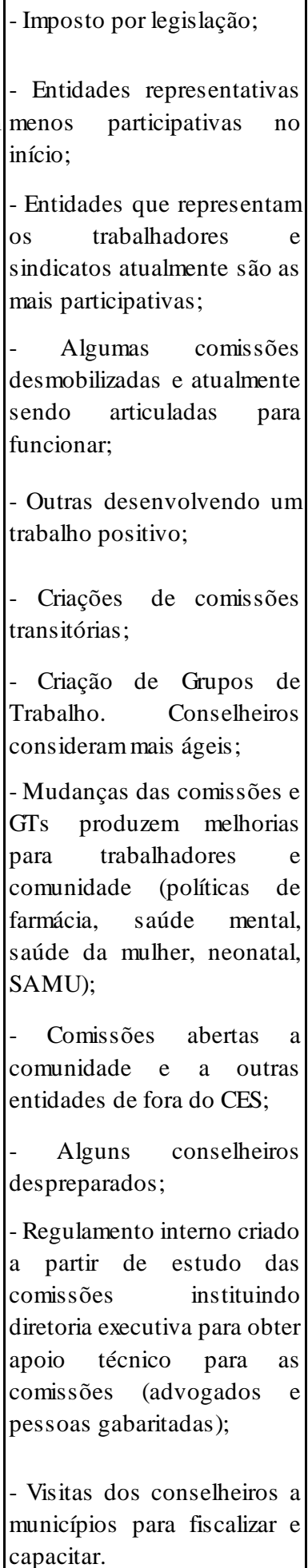 & 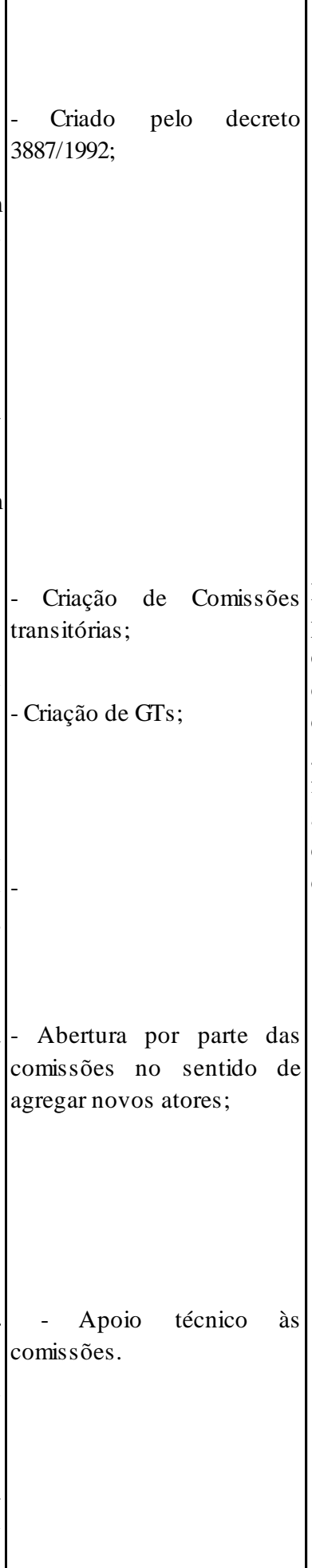 & $\begin{array}{l}\text { Restrita: o CES foi criado } \\
\text { por decreto e na medida em } \\
\text { que foram surgindo novas } \\
\text { demandas foram criadas } \\
\text { comissões transitórias e } \\
\text { grupos de trabalho. Dessa } \\
\text { forma, passou a ter alguma } \\
\text { atividade, mas com algumas } \\
\text { comissões } \\
\text { desmobilizadas. }\end{array}$ \\
\hline
\end{tabular}

Quadro 10 - Categorização do indicador implantação e departamentalização - CES/GO.

Fonte: Baseado em Silva (1999). 


\subsubsection{Tradução das Demandas da Comunidade}

\subsection{Avaliação das Necessidades da Comunidade}

A categorização para o indicador avaliação de necessidades no Conselho Estadual de Saúde de Goiás tende a ser média. As categorias intermediárias que fundamentam essa tendência são: "Avaliação das necessidades por diferentes meios", "Plano Anual de Trabalho é discutido nas plenárias", "Conselho pauta discussões em conferências e na elaboração do Plano de Saúde" e "Hierarquia de solicitações avaliada pela Diretoria Executiva". Como forma de justificar a referida tendência tem-se a questão das necessidades serem trazidas em grande parte pelos próprios conselheiros de saúde, que, segundo as entrevistas, estão mais próximos das demandas da saúde no Estado. Além disso, existem outros canais receptivos às demandas da saúde, como as questões levantadas em fóruns de discussões das entidades representativas dos conselheiros, denúncias realizadas pela própria população e mídia - posteriormente recepcionadas e discutidas pelo Conselho; e também por meio dos Planos Anuais de Trabalho da Secretária de Saúde que apresentam demandas da saúde para o CES deliberar, até mesmo em virtude do Plano Estadual de Saúde. Os referidos elementos fundamentam a categoria teórica intermediária "avaliação das necessidades por diferentes meios".

Adicionalmente, cita-se a participação dos conselheiros em fóruns, conferências e seminários - além dos realizados pelas entidades representativas dos conselheiros - no intuito de trazer questões, discutidas nesses espaços, relativas aos anseios da comunidade, para o pleno da instituição participativa. Vale lembrar também que o conselho se utiliza de Comissões Intergestores para tratar assuntos que não estão diretamente ligados à matéria da saúde, mas que podem ter consequências para ela como, por exemplo, qualidade da água, questões de trânsito, condições de trabalho dentre outros. Em face do exposto, formulou-se a categoria teórica intermediária "Conselho pauta discussões em conferências e na elaboração do Plano de Saúde".

A conselheira 04 (segmento prestadores de serviço) argumenta que os conselheiros de saúde possuem papel importante na identificação das necessidades e descreve como isso ocorre no CES/GO:

Hoje se baseia mediante a necessidade da população da entrada das políticas dentro do Conselho, da entrada até mesmo da prestação de contas. Um exemplo é a avaliação que fizemos na última reunião de plenária na qual aprovamos os indicadores de saúde do Estado. Nós identificamos itens que precisam ser amplamente debatidos, inclusive 
algumas diretrizes que constam no Plano Estadual de Saúde que não estão sendo cumpridas da forma que deveriam. O conselheiro traz esta consciência de grupo, cada grupo traz sua necessidade, demanda. O conselheiro acaba tendo papel fundamental para identificar necessidades, pois vivencia os problemas e a sociedade.

Apesar da importância dos conselheiros no que se refere à identificação das demandas destacam-se outros canais para tal. O conselheiro acaba sendo parte de um rol de possibilidades, ou seja, não existe apenas ele para trabalhar as demandas da comunidade. Nesse sentido, o conselheiro 05 (segmento usuários) avalia que:

No âmbito do Conselho Estadual, Municipal, em qualquer instância de Conselho de Saúde, ela (necessidade) tem que ser identificada por meio das entidades. Na verdade, eu como conselheiro, devo fazer relatório diariamente para a minha entidade e discutir as questões de saúde na minha entidade. Por quê? Porque as pessoas que contribuem na minha entidade moram em lugares longínquos e sabem a verdadeira necessidade da saúde para o povo. Então é nessa concepção que tem que ser feito o trabalho dentro Conselho.

A visão do conselheiro 05 (segmento usuários) representa a fala de outros conselheiros no sentido de deixar claro a participação de algumas entidades, outrora menos atuantes, na recepção e no atendimento às demandas sociais da área de saúde. Por outro lado, a conselheira 06 (segmento trabalhadores) destaca que as necessidades da comunidade podem também ser identificadas “por meio dos Planos Anuais de Trabalho apresentados pela Secretária de Saúde, que manda as demandas para o Conselho Estadual de Saúde deliberar. E às vezes pelos conselheiros que levam denúncias para o Conselho orientar encaminhamentos". A partir daí formulou-se a categoria teórica intermediária "Plano Anual de Trabalho é discutido nas plenárias".

Ainda com respeito às denúncias, a conselheira 02 (segmento usuários) afirma "a gente acompanha muito a questão da demanda e da necessidade da comunidade, no geral do SUS, pela mídia”. Então, além dos conselheiros trazerem demandas verificadas na saúde, também acabam recebendo denúncias e discutindo-as, o que indica a representação, pelo menos em parte, do ponto de vista da comunidade.

Adicionalmente, a conselheira 04 (segmento prestador de serviço) informa que existe um trabalho realizado por comissões cujo foco é justamente discutir, de maneira conjunta, assuntos que envolvem também outras áreas: "eu acho que a saúde tem que ser 
discutida com outros assuntos como educação, alimentação e segurança”. De maneira complementar, o conselheiro 03 (segmento usuários) informa que o CES:

Possui algumas comissões interligadas ao Conselho, compostas por pessoas de outros segmentos que trazem essa visão para a gente, permitindo novas discussões e levando essas propostas para se englobar ao plano da saúde e conferencias de saúde.

Nota-se que a discussão das demandas em determinado momento se insere em fóruns de discussão, bem como no plano de saúde destinado às ações a serem praticadas no Estado, com intuito de atender às demandas da sociedade. Diante das razões expendidas neste tópico, verifica-se - em termos de ganho para o controle social - uma participação mais ativa e mais consciente das demandas de saúde, fato que apresenta uma evolução se considerados os relatos do conselheiro 09 - mais antigo - os quais apresentaram menor participação do CES para com o controle social na implantação do Conselho.

Após a exposição de alguns aspectos que estão relacionados a categorização do indicador avaliação das necessidades cumpre-se destacar um ponto que restringe a ideia de tendência aberta para o mesmo. Trata-se da Mesa diretora, composta da Secretaria Executiva, criada pelo regimento interno em seu art. 34, estabelecer hierarquia de prioridades nos encaminhamentos das discussões - similar a Secretaria Executiva instituída no Conselho Municipal de Saúde de Porto Alegre, aspecto verificado por Silva (1999). Especificamente para o caso de Goiás o estabelecimento de prioridades para os encaminhamentos das discussões a respeito das necessidades da saúde, realizado pela Secretaria Executiva, fere uma atribuição que deveria ser de competência das próprias comissões que realizaram os estudos e confeccionaram pareceres para fundamentar o processo decisório do CES. Diante disso, formula-se a categoria teórica intermediária "Secretaria Executiva Estabelece Hierarquia de prioridades para o encaminhamento das discussões sobre as necessidades".

Entende-se que as comissões são formadas por indivíduos que detêm as competências necessárias tanto para elaborar o parecer quanto para acompanhar a situação dos casos analisados por elas. Dessa forma, foi considera tendência média para a avaliação das necessidades no CES/GO. O quadro 11 apresenta a categorização do indicador avaliação das necessidades. 


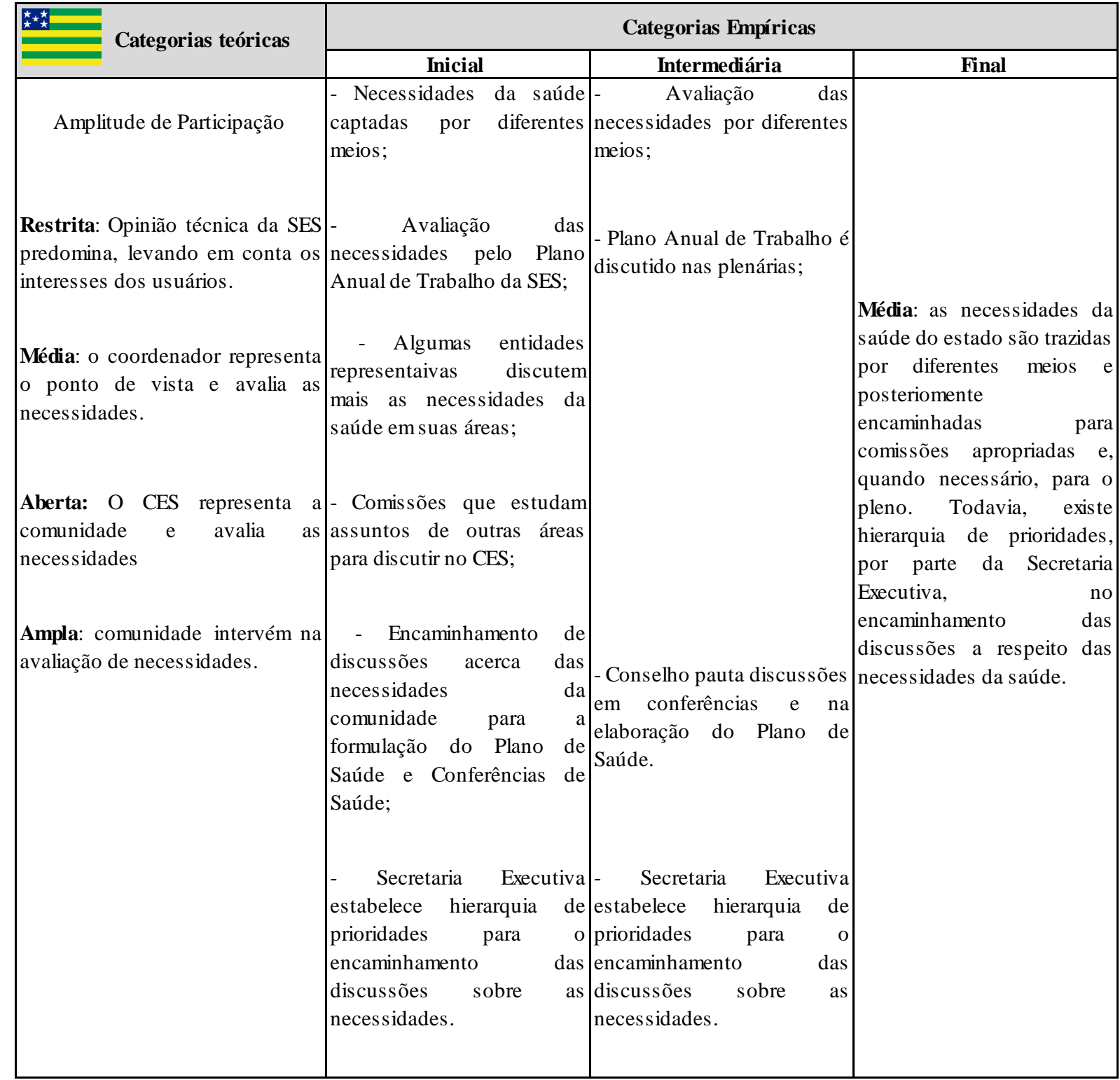

Quadro 11 - Categorização do indicador Avaliação das Necessidades - CES/GO.

Fonte: Baseado em Silva (1999).

\subsection{Liderança}

A tendência para o indicador liderança no CES/GO foi considerada média, apesar de existirem aspectos positivos. O ponto focal dessa motivação está ligado ao fato das deliberações do CES muitas vezes não serem homologados pelo governo. Esse tipo de característica acaba, de certa forma, silenciando os esforços do Conselho, tendo em vista a barreira governamental da não efetividade. A categorização desse indicador foi fundamentada em aspectos, considerados aqui como categorias intermediárias, relativos a "Liderança exercida pelos movimentos populares", "Lideres natos" principalmente representados pelo presidente do 
Conselho (segmento usuários) e, em determinados momentos, pelos trabalhadores da saúde; "Deliberações não homologadas pelo governo", "Benefícios parciais gerados para a comunidade em virtude das decisões do Conselho" e "Conselheiros bem articulados". Apesar dos elementos apresentados remeterem à tendência aberta - onde o Conselho possui inciativa e é ativo - a não efetividade insere a figura de um gestor estadual de saúde independente, ou seja, com tendência média.

Em relação às "lideranças de movimentos populares" verifica-se que tanto os usuários como trabalhadores da saúde - apontados como maiores lideranças do CES/GO representam movimentos populares legitimados por interesses de grupos, associações, sindicatos e conselhos de classe. O conselheiro 07 (segmento gestores) aborda a questão afirmando que:

A militância no controle social da saúde se dá por representantes que possuem algum interesse na saúde de forma que possa interferir nas decisões da política de saúde. No grupo dos usuários a predominância é de representantes de grupos de pacientes com alguma patologia e /ou associações de portadores de doenças, outro grupo de usuários são os representantes sindicais de diversas áreas e a igreja. No dos trabalhadores são os sindicatos, conselhos de classe e associações de trabalhadores da saúde.

A presença de um líder nato no caso deste Conselho agrega valor tanto às discussões realizadas no pleno, com respeito às demandas da saúde, como maior confiança na relação entre os conselheiros. De certa forma o ambiente do controle social, pelo menos no âmbito do Conselho, ganha força, pois há uma relação de apoio no sentido de agregar opiniões para solucionar problemas de saúde - visão apresentada por Silva (1999). Diante disso, a conselheira 01 (segmento usuários) afirma que "líder mesmo do Conselho é o presidente (segmento usuários)", apontamento também confirmado pela conselheira 06 (segmento trabalhadores) "o presidente é que se destaca, a assessoria de mesa dele é que colabora nas deliberações das reuniões e tem este espirito de liderança".

Soma-se a isso o fato dos trabalhadores da saúde em determinados momentos apresentarem aspectos de liderança e assumirem a dianteira de determinadas discussões. Isto mostra, em princípio, que há uma alternância benéfica em termos de contribuições para o processo deliberativo do CES. A conselheira 04 corrobora essa ideia afirmado: "eu acho que no Conselho de Goiás o grupo que se torna forte é do trabalhador. Na maioria das vezes temos um grupo equilibrado, mas que oscila às vezes". 
A Liderança responde de forma parcial às necessidades da comunidade. Sobre essa questão é importante destacar que mesmo tendo inciativa, o CES por si só não garante o cumprimento de suas deliberações, pois é preciso que estas sejam homologadas pelo governo do Estado, fato que nem sempre ocorre. O conselheiro 03 (segmento usuários) ao abordar a questão relacionada à produção de melhorias por parte das deliberações do CES afirma que isso ocorre "em parte, porque evidentemente o trabalho que realizamos muitas vezes não é efetivado (homologação do governo)". Esse ponto reforça uma característica de tendência média, pois o gestor parece atuar alheio às necessidades da população e, por consequência, às reivindicações do CES. Diante do exposto, foi formulada a categoria teórica intermediária "decisões que buscam benefício para a comunidade, mas sem efetividade".

Outro ponto a ser destacado como entrave ao atendimento das demandas da comunidade se refere a questão das informações contidas nos relatórios de prestações de contas, que em muitos casos, não são tempestivas. Para a conselheira 06 (segmento trabalhadores) "ela (demanda) chega tardia, a maioria das demandas que chegam para o Conselho já aconteceu, passou do prazo, e as nossas decisões não vão mudar mais o que já passou". Esse outro fator pode estar ligado informações de prestações de contas que não são entregues no prazo, falta de comunicação com determinadas entidades que fazem parte do controle social dentre outros fatores.

Mesmo diante do cenário apresentado sobre o atendimento às demandas e a produção de melhorias para a comunidade - que ainda padece de progressos para avançar no controle social - é possível considerar, de acordo com a percepção dos conselheiros de saúde do Estado de Goiás, que mesmo com os entraves são produzidas melhorias para comunidade em geral. Dos oito conselheiros entrevistados seis afirmaram que as decisões do Conselho produzem melhorias. O conselheiro 08 (segmento trabalhador) expressa esse pensamento argumentando que são produzidas melhorias “embora seja em nível inferior ao que o Controle Social se propõem, mas tem surtido efeito positivo sua atuação como co-gestor (o CES) nas políticas públicas de saúde.”.

Por fim, destaca-se a presença de conselheiros bem articulados no desenvolvimento das atividades e interlocução com as entidades que fazem parte do controle social (associações, sindicatos, conselhos de classe dentre outros) - panorama que não se confirma para todos os conselheiros estaduais. A articulação mencionada resulta em ações que podem beneficiar a população. Diante disso, formulou-se a categoria teórica intermediária "conselheiros bem articulados". 
No entanto, não é o que se verifica diante da falta de efetividade do Conselho. Segundo o conselheiro 03 (segmento usuários):

Dentro do Conselho muitos exercem a liderança, mas nesse quadro especifico eu diria que são as próprias pessoas das entidades que se destacam, no conhecimento do Conselho, na representação que ele tem diante dos outros componentes, da maior desenvoltura e boas ações.

Seguindo a mesma ideia de articulação de alguns conselheiros a conselheira 04 (segmento prestadores de serviço) considera que em relação à conduta do indivíduo que integra o pleno do CES “é preciso fazer a diferença nas discussões. Eu sou coordenadora de plenária e consigo enxergar que é um trabalho de muita conscientização dos municípios através do controle social.". É possível notar a partir deste fragmento que existe um trabalho de articulação desenvolvido pelos conselheiros no sentido de cumprir uma das atribuições do CES, que é auxiliar os Conselhos Municipais de Saúde. Em face do exposto neste tópico o quadro 12 apresenta a categorização do indicador Liderança.

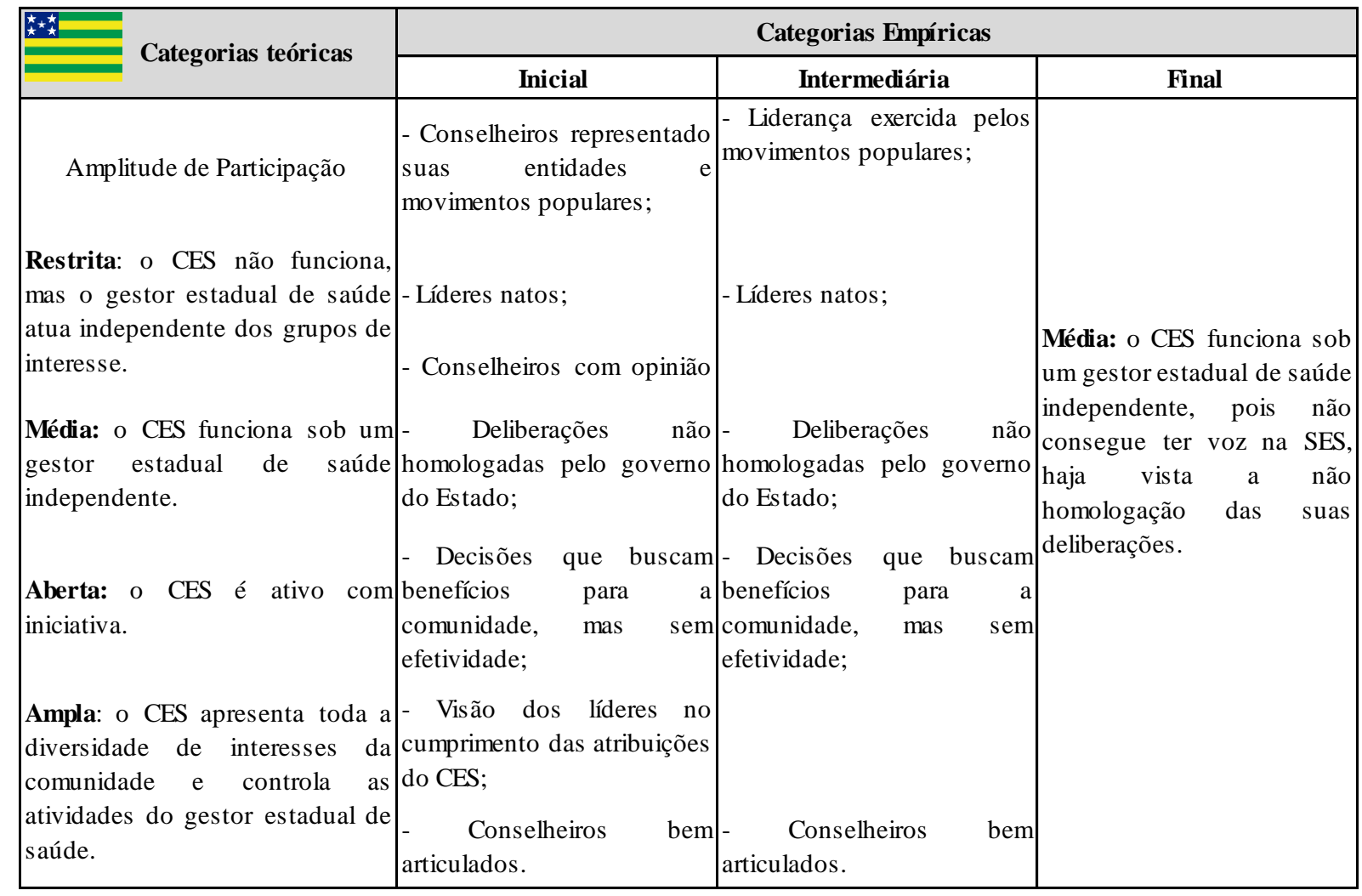

Quadro 12 - Categorização do indicador Liderança - CES/GO.

Fonte: Baseado em Silva (1999). 


\title{
4.1.1.2.3 Mobilização de Recursos
}

A tendência para o indicador mobilização de recursos foi considerada média por se verificar que o Estado recebe repasses periódicos, mas a população apenas acompanha a aplicação dos recursos da saúde. Nesse sentido, as seguintes categorias teóricas intermediárias fundamentaram essa tendência: "Governo federal faz repasses periódicos", "Estado repassa 12\% de seu orçamento", "Gestor estadual apenas apresenta contas ao CES" e a "População apenas acompanha a aplicação de recursos".

O conselheiro 08 (segmento trabalhadores) aborda o trabalho realizado pela comissão responsável por fiscalizar a aplicação de recursos na saúde e a questão dos repasses periódicos dos entes federados. Outro ponto importante, destacado pelo conselheiro, está relacionado a chegada dos recursos na ponta (atendimento das demandas da saúde), sob o argumento de que o recurso pode ser alocado de forma tardia em determinadas finalidades.

\begin{abstract}
O CES tem uma Comissão denominada COFIN (Comissão de Orçamento e Finanças) que tem por objetivo analisar, fiscalizar, emitir parecer sob as contas públicas voltadas aos recursos destinados à saúde. Geralmente se verifica que a União repassa os recursos, bem como o Estado e Municípios. No caso do Estado verificamos nas prestações de contas que os recursos repassados cumprem os $12 \%$ constitucionais, até mesmo chegam a superá-los em determinados momentos. O problema é que em muitas vezes até os recursos serem aplicados de fato, acaba demorando mais do que a brevidade que a saúde precisa. Existe morosidade.
\end{abstract}

O conselheiro 01 (segmento usuários) vai um pouco mais além ao considerar se os repasses de recursos são efetivamente garantidos pelos entes federados, pois menciona que além da morosidade na chegada do recurso na ponta, em determinadas situações, o mesmo chega a ser devolvido.

Esses recursos que são do Governo federal até chegar lá na ponta, onde deve ser aplicado, se perde muito pelo caminho. Ele não chega na totalidade que sai de lá. E muitas vezes tem que devolver este recurso porque é tão lenta a gestão pública que deixa passar o prazo, não se constrói, não avança, e o recurso às vezes é devolvido. (grifo do autor)

Já com respeito à destinação dos recursos conforme diretrizes do PES, seis dos oito conselheiros afirmaram que se busca atender as diretrizes do plano. Para a conselheira 02 (segmento usuários) as "alocações de recursos são observadas na íntegra (pelo CES) de todo o plano", ou seja, é, na visão da conselheira, "fiscalizado" de acordo com as necessidades da 
população constantes nas diretrizes do PES. No entanto, vale salientar que nem sempre os recursos são aplicados conforme previsão orçamentária, bem como no plano da saúde e além disso ainda existe a devolução de recursos. Sob essa ótica, torna-se necessário considerar que a referida "fiscalização" é incipiente, pois caso fosse efetiva não haveria devolução de recursos. É com esse pano de fundo que verifica-se a não existência de indicadores claros que demonstrem o controle dos gastos da saúde por parte do CES. De certa forma esse cenário apresenta uma falsa ideia de controle dos gastos por parte dos conselheiros, pois os mesmos acreditam que os recursos são alocados e controlados. Segundo o conselheiro 04 (segmento prestadores de serviço) os gestores da saúde:

\footnotetext{
Procuram contemplar o Plano Estadual de Saúde, mas nem sempre é executado exatamente como são previstos. Então, eu acho que é nosso papel uma discussão maior do porquê? No sentido de verificar o que está acontecendo. Ir atrás e procurar saber. Só que é muito difícil você fazer um trabalho voluntariado onde tem que ser feita à análise, o acompanhamento e o retorno ao mesmo tempo. (grifo do autor)
}

Sob este prisma, é possível considerar que o fato de o Conselho Estadual de Saúde, por meio de sua comissão (COFIN), verificar o cumprimento de parte das diretrizes, destaca que o gestor apenas apresenta as contas sobre a aplicação dos recursos destinados à saúde, pois a partir dos relatórios de prestações contas é que se verifica que nem sempre os recursos são aplicados como deveriam. $\mathrm{O}$ ato de prestar contas deveria estar alinhado aos preceitos normativos, por exemplo, da LC 141/2012 e na análise dos relatórios de prestação de contas seção 4.2 - fica claro que aplicação dos recursos não segue integralmente o preconizado. Logo, não é possível considerar que o gestor preste contas efetivamente sobre a sua gestão da saúde. Diante disso, o quadro 13 apresenta uma síntese da categorização do indicador mobilização de recursos no CES/GO. 


\begin{tabular}{|c|c|c|c|}
\hline \multirow{2}{*}{ Categorias teóricas } & \multicolumn{3}{|c|}{ Categorias Empíricas } \\
\hline & Inicial & Intermediária & Final \\
\hline $\begin{array}{l}\text { Amplitude de Participação } \\
\text { Restrita: os recursos são } \\
\text { provenientes da prestação de } \\
\text { serviços. O CES não controla o } \\
\text { pagamento de honorários. }\end{array}$ & $\begin{array}{l}\text { - Governo Federal repassa } \\
\text { os recursos periodicamente; } \\
\text { - Governo do Estado } \\
\text { repassa os } 12 \% \text { previstos na } \\
\text { constituição; }\end{array}$ & $\begin{array}{l}\text { - O Governo Federal faz } \\
\text { repasses periódicos; } \\
\text { - Estado repassa } 12 \% \text { do } \\
\text { seu orcaemento; }\end{array}$ & \\
\hline $\begin{array}{l}\text { Média: contribuição periódica da } \\
\text { União, do Estado e do Município, } \\
\text { sem participação da comunidade } \\
\text { no controle dos gastos. } \\
\text { Aberta: Contribuição periódica da } \\
\text { União, do Estado e do Município, } \\
\text { o CES controla a utilização dos } \\
\text { gastos. }\end{array}$ & $\begin{array}{l}\text { - Gestor estadual apenas } \\
\text { apresenta contas ao CES; } \\
\text { - A população acompanha a } \\
\text { aplicação de recursos; } \\
\text { - Eventuais devoluções de } \\
\text { recursos; }\end{array}$ & $\begin{array}{l}\text { - Gestor estadual apenas } \\
\text { apresenta contas ao CES; } \\
\text { - A população acompanha a } \\
\text { aplicação de recursos. }\end{array}$ & $\begin{array}{ll}\text { Média: } & \text { contribuição } \\
\text { periódica de recursos pela } \\
\text { União, Estado e Municípios, } \\
\text { em que a comunidade não } \\
\text { particpa do controle dos } \\
\text { gastos. }\end{array}$ \\
\hline $\begin{array}{l}\text { Ampla: Volume considerável de } \\
\text { recursos de origens diversas. O } \\
\text { CES decide a utilização dos } \\
\text { fundos. }\end{array}$ & $\begin{array}{l}\text { - Morosidade na aplicação } \\
\text { dos recursos. }\end{array}$ & & \\
\hline
\end{tabular}

Quadro 13 - Categorização do indicador mobilização de recursos - CES/GO.

Fonte: baseado em Silva (1999, p. 104).

\subsubsection{Amplitude de Participação Social da Comunidade no CES/MT}

A amplitude de participação social é composta por duas subdimensões. A primeira delas é a dimensão histórica que objetiva verificar questões relacionadas ao processo de implantação e departamentalização do Conselho, ou seja, como este se organiza em novas estruturas, como integra novos temas de saúde e que mudanças ocorreram desde a sua implantação (SILVA, 1999). A segunda subdimensão, tradução de demandas, na visão de se Silva (2005), busca avaliar as demandas da sociedade, inclusive como são recebidas e avaliadas pelo Conselho, bem como o tipo de liderança que figura neste cenário, além de verificar, também, a mobilização de recursos para atender às referidas demandas.

\subsubsection{Implantação e Departamentalização (Dimensão Histórica)}

A avaliação da dimensão histórica no Conselho Estadual de Saúde de Mato Grosso, após análise das entrevistas, apresentou um cenário no qual cinco dos oito conselheiros 
entrevistados detinham conhecimento maior do momento da implantação ou vivenciaram alguma experiência que remetia àquela fase. O tempo de experiência no exercício das atribuições, em média, dos conselheiros entrevistados foi de oito anos, fator que apresenta, em princípio, maior possiblidade de conhecimento da trajetória histórica do Conselho. A busca por complementar a visão dos oito conselheiros entrevistados encontrou justificativa no fato das atas plenárias, fonte importe de conhecimento da história do CES, só estarem disponíveis para o intervalo de 2008 a 2013, contrariando a legislação vigente. O fato é que atas deveriam estar disponíveis desde de 1992 e isso prejudica a uma avaliação mais profunda acerca da história do Conselho. Por conta disso, seguiu-se a metodologia de entrevistar o conselheiro mais antigo, indicado pelo CES, para enriquecer a avaliação da perspectiva histórica do mesmo.

A implantação do CES/MT, na visão dos conselheiros, ocorreu em virtude de imposição legal, mais especificamente pela Lei Complementar estadual 22/1992, em cumprimento à lei 8.080/1990. Parte das indagações que fornecem suporte à consideração da imposição legal para criação do conselho encontram sustentação na afirmativa do conselheiro 01 (segmento usuário): “eu creio que a legislação da época consistia em: estabeleça o conselho se não fica impedido de utilizar o recurso". Todavia, o governo do estado de Mato Grosso relutou em considerar a norma - 8.080/1990 - por acreditar que não haveria sanção em caso de descumprimento relativo à criação do conselho. Posteriormente, à não concordância do governo em reconhecer a ideia de possuir alguma instituição participativa foi quebrada, por ocorrência do bloqueio de recursos para a saúde. A conselheira 05 (segmento trabalhadores) tematiza a referida questão:

\footnotetext{
O governo na época resistiu ao máximo, acho que desacreditou que pudesse realmente sofrer sanção. Aí o governo chegou em Brasília para pedir recursos, na época você ia buscar recurso, diferente de como é hoje que eles mandam diretamente do fundo [...] então, o governador chegou em Brasília e encontrou portas fechadas, e justificaram que ele não tinha criado o Conselho, e quando ele retornou ligou para o secretário de saúde, e o mesmo disse que o primeiro passo era montar o Conselho; e ter uma secretária que soubesse escrever bem, e que fizesse a ata. Os recursos ficaram bloqueados e eu fui chamada para fazer o procedimento de abertura, e ele acabou saindo em cinco dias porque os órgãos cooperaram [...] quando teve interesse político as coisas aconteceram. Por isso, a criação foi imposta.
}

A fala da conselheira deixa claro que a implantação do CES ocorreu por meio de imposição legal, sem considerar o envolvimento da sociedade na tentativa de exercer pressão para criação da instituição participativa. Considera-se que a comunidade estava a par da necessidade de se instituir um espaço público de participação social e até chegou a discutir a 
questão, bem como tentou pressionar, mas sem efetividade, razão pela qual a criação, mesmo, acabou vindo por conta somente de dispositivo legal - fruto da necessidade de recursos para o Estado (bloqueados em determinado momento pela falta do Conselho). Na verdade, o que se apresenta é a indiferença do Governo do Estado de Mato Grosso à época no sentido de acatar as pressões populares e criar o Conselho. Na perspectiva apresentada, a conselheira 06 (segmento usuários) destaca:

Aqui no Mato Grosso a pressão para se ter um Conselho foi tomando forma primeiro nos movimentos. Depois houve uma pressão para a consolidação do Conselho e na época o gestor era sanitarista. Aconteceu muita pressão. Mas a criação só veio por imposição legal, para a formação dos conselhos, senão não teríamos verba.

Em face do cenário exposto, destacam-se dois aspectos: i) houve mobilização da população no sentido de acompanhar e cuidar da ideia de estabelecer um ambiente mais democrático e transparente na saúde, e ii) após a criação os movimentos começaram a atuar de forma mais presente no controle social. O conselheiro 09, mais antigo do conselho, (segmento usuários) afirma em relação ao primeiro aspecto:

Eu mesmo, por exemplo, era presidente de uma igreja Católica, mas no movimento negro não tinha acento. Contei com a ajuda de um rapaz que representava o MOPS (Movimento Popular de Saúde) que me chamou a participar do movimento para garantirmos a participação do mesmo dentro do Conselho [...] Hoje, eu considero que o Conselho está menor em relação a aquela época. Naquela época, a luta pela redemocratização do Estado contra o Golpe Militar foi grande. Nesse momento já lutávamos por democracia e transparência.

Em outra via, o conselheiro 09 (segmento usuários) afirma, em relação a eleição dos conselheiros, que "desde os primeiros momentos foi por meio de eleição. Na Lei Complementar 22 tem o nome das entidades, mas a entidade tem que fazer um processo democrático, uma eleição para escolher titular e suplente". A visão do processo democrático de eleição abre espaço para a questão da integração dos movimentos sociais à estrutura da instância participativa. Nesse sentido, em consonância com o segundo aspecto - atuação mais presente de movimentos sociais - foi abordado que "outros movimentos como o das mulheres e negros participaram de toda a construção, depois da imposição legal, para dar forma aos pensamentos dos movimentos" conselheira 6 (segmento usuários). 
Ainda com respeito aos relatos históricos do CES o conselheiro 09 (segmento usuários) aborda a questão da paridade: "de acordo com a lei, ela sempre foi respeitada, alguns questionam, por conta da questão da presidência, falam que não é paritária, mas como somos cadastrados no Conselho Nacional de Saúde, no Sistema de Acompanhamento dos Conselhos (SIAC), o mesmo é paritário lá”. O único questionamento quanto à questão da paridade ocorre em virtude do CES possuir trinta conselheiros mais o presidente, que é nato. Todavia, o CNS reconhece que a paridade está de acordo. Esse tipo de formatação pode ocasionar viés nas decisões do Conselho, dado que o presidente está diretamente ligado à gestão da saúde do Estado. Por oportuno, ressalta-se que a resolução do CNS 453/2012 é desrespeitada no sentido de que o presidente deve ser eleito democraticamente.

Em relação às demandas do Conselho na SES o conselheiro 09 afirma que em parte são acatadas. Ainda menciona o seguinte: "a meu ver, sim. Aquilo que o conselheiro solicitou e ele continuou cobrando foi acatado. Agora não sei se aquilo que propusemos e não cobramos foi acatado". Esse cenário, em princípio, exibe condição menos favorável de controle social na relação entre o CES e a Secretaria, pois o gestor não é transparente, fato que promove a necessidade de cobrança. Em outra via o conselheiro considera que boa parte da população não conhece a figura do Conselho de Saúde, bem como não sabe das suas atribuições. O conselheiro 09 relata isso no seguinte fragmento "o problema central da população é o desconhecimento, informação, que muitas vezes não sabem que existem Conselhos ou não sabem o poder que um Conselho tem". Todavia, quando são realizadas conferências de saúde regionalizadas, parte da população passa a ter "sua participação maior que dos conselheiros". Portanto, verifica-se que apenas uma pequena parte da população se sente parte integrante da gestão da saúde.

Por fim, o conselheiro 09 (segmento usuários) argumenta que o estado de Mato Grosso sofre uma influência político-partidária muito forte e que isso, eventualmente, dificulta o planejamento e o orçamento das aplicações de recursos na saúde.

Existe uma influência muito forte, principalmente, quando se trata de planejamento e orçamento. Esta é a peça fundamental, o momento crucial do conselho quando está discutindo a Lei de Diretrizes Orçamentárias (LDO). Um exemplo é: Nós vamos elaborar o PPA, temos este ano 1 bilhão para a saúde. A onde aplicar este recurso? A lei 141/2012 diz que a responsabilidade, inclusive, administrativa também é dos conselheiros, juridicamente. O conselheiro tem que estar ciente, de acordo com o Plano Estadual de Saúde, de acordo com a demanda da conferência. Qual é a maior necessidade na saúde da população? É atenção primária! Saúde da família! O conselheiro tem que ter bastante clareza de como está formado o SUS de Mato Grosso. Porque o SUS de Mato Grosso hoje tem 16 regionais e o conselheiro tem que obedecer 
esta regionalização. Temos que olhar para o Plano Diretor Regional (PDR) e o Plano Diretor de Investimento (PDI). O momento crucial para o conselheiro é a hora de aprovar o recurso - onde vem a pressão por parte do governo. (grifo do autor)

Por outro lado, vale destacar questões relativas à criação de novas comissões e a flexibilidade das já existentes (departamentalização), pois estas podem demonstrar fatores importantes, quais sejam: i) capacidade do Conselho em captar novas demandas no sentido de discuti-las e atendê-las; e ii) a versatilidade das comissões existentes em abarcar novos assuntos (SILVA, 1999). Das comissões já existentes, 10 instituídas por lei, de forma permanente, verificou-se que grande parte das demandas apresentadas pela comunidade é recepcionada. $\mathrm{Na}$ visão da conselheira 05 (segmento trabalhadores), as comissões já existentes são satisfatórias. A conselheira complementa afirmando que "conforme regimento, podemos criar comissões especiais temporárias. Mas a grande maioria das questões que nos chegam as comissões já existentes estão correspondendo". A conselheira 03 (segmento usuários) trata a questão com a afirmativa de que "podemos considerar que são flexíveis para captar novos assuntos".

Já com respeito à criação de novas comissões, o conselheiro 01 (segmento usuários) considerou que demandas novas acabam gerando novas necessidades - às vezes ainda não contempladas pelas comissões existentes. Não obstante, é possível mencionar que as referidas comissões podem não possuir tempo para analisar um fluxo diferente de informações, outras demandas - dada a sobrecarga de trabalho. Quando perguntado se novas comissões são criadas na medida em que surgem novas demandas da comunidade o conselheiro 01 afirmou:

Sim. Nós temos 10 comissões permanentes, temos outras que trabalham com causas externas. Quando necessário, para um tema mais específico que foge daquela área ou quando as comissões já estão sobrecarregas, se institui outra comissão trazendo pessoas de outros setores sem ser do conselho, aliado a algumas pessoas do Conselho. Compõem-se uma comissão sob a responsabilidade do Conselho e dá poderes a esta comissão para que ela trabalhe assuntos específicos.

A conselheira 03 (segmento usuários) apresentou exemplo relativo ao problema de regulação existente no Estado "o conselheiro pode propor que se estruture uma comissão para trabalhar a regulação - uma comissão não permanente, pois as permanentes são as que estão na lei”. Oportunamente, cumpre-se destacar a menção do conselheiro 09 à oportunidade de criação de novas comissões que não integrem somente pessoas vinculadas ao CES. Isto caracteriza departamentalização inclusiva do ponto de vista social e, por conseguinte, fornece caminhos para maior participação popular. Na realização da VIII Plenária de Conselheiros de Saúde/MT, 
realizada em agosto de 2014, momento da realização da pesquisa de campo, houve participação de Professores da Universidade Federal de Mato Grosso e de um Procurador do Estado nas discussões o controle social em Mato Grosso. Esses são exemplos da participação de atores de fora do Conselho nas discussões realizadas no mesmo.

Em contraponto à criação das comissões e a estruturação do CES é necessário destacar um aspecto levantando por boa parte dos conselheiros entrevistados. Ocorre que o Conselho perdeu ao longo do tempo parte de suas coordenadorias e assessorias. A justificativa está motivada em questões políticas e interesses do governo do Estado. A conselheira 05 (segmento trabalhadores) afirmou que "fizeram um desmonte no Conselho, tiraram as nossas coordenadorias [...] então, este Conselho aí, nestes 12 anos, não teve nenhum tipo de respeito por parte do governo". O referido entrave somado à questão de parte das resoluções não serem homologadas pelo governador apresenta um cenário que dificulta o encaminhamento de melhorias para a comunidade, a partir da atuação do CES. Para conselheira 05 "o que foi colocado em pauta no Conselho temos as repostas para todas elas. Mas tudo tem seu limite, chegou uma demanda aqui quem homologa? As resoluções nós fizemos, cumprimos. O governador que não homologou, não cumpriu".

A conselheira 03 (segmento usuários) argumentou que "mesmo com essas dificuldades podemos perceber que o Conselho Estadual atende a essas demandas sim. Mas com muita dificuldade". Em outra via, avalia-se que parte das mudanças ocorridas no CES, em termos de departamentalização, foram benéficas para os profissionais da saúde e/ou comunidade. Nessa perspectiva, o conselheiro 01 (segmento usuários) afirma que:

\footnotetext{
Sim, pois essa flexibilidade de estar trazendo (mudanças em comissões) e intervindo de forma positiva ajuda. Eu tenho plena certeza que todas as vezes que o conselho interfere ou é chamado a interferir, ou detecta uma demanda que necessita a presença, com certeza a situação começa a mudar. Recentemente nós tivemos um setor que estava insalubre, teve um incêndio e o Conselho simplesmente pediu que as coisas parassem e a gestão resolvesse o problema, para que tivesse uma melhor qualidade de atendimento, melhor qualidade de trabalho no ambiente de serviço do profissional.
}

A perspectiva apresentada pelo conselheiro denota que, pelo menos parte, as demandas apresentadas e trabalhadas no CES, por meio de comissões já existentes, podem beneficiar tanto os profissionais da saúde quanto a comunidade. Em meio as questões apresentadas existem duas ferramentas, em especial, que o Conselho se utiliza para buscar 
produzir melhorias para a comunidade, quais sejam: ouvidoria e comissão de monitoramento e cooperação com municípios. A conselheira 03 (segmento usuários) aborda da seguinte forma:

Nós temos no Conselho uma Ouvidoria que é diretamente ligada ao Conselho Estadual. Essa ouvidoria é ligada ao pleno do Conselho, e ela é um indicador de saúde pública. Nós temos também outra estratégia no Conselho Estadual de Saúde que é uma comissão de monitoramento. A gente monitora as unidades estaduais e faz cooperação técnica com os municípios.

Diante do exposto, a tendência da amplitude de participação para o indicador implantação e departamentalização, pode ser considerada média, visto que além de apenas criar comissões, o CES se mostra ativo em relação à forma como se estrutura para atender as demandas da saúde. Diante disso, o quadro 14 apresenta a categorização do indicador mencionado. 


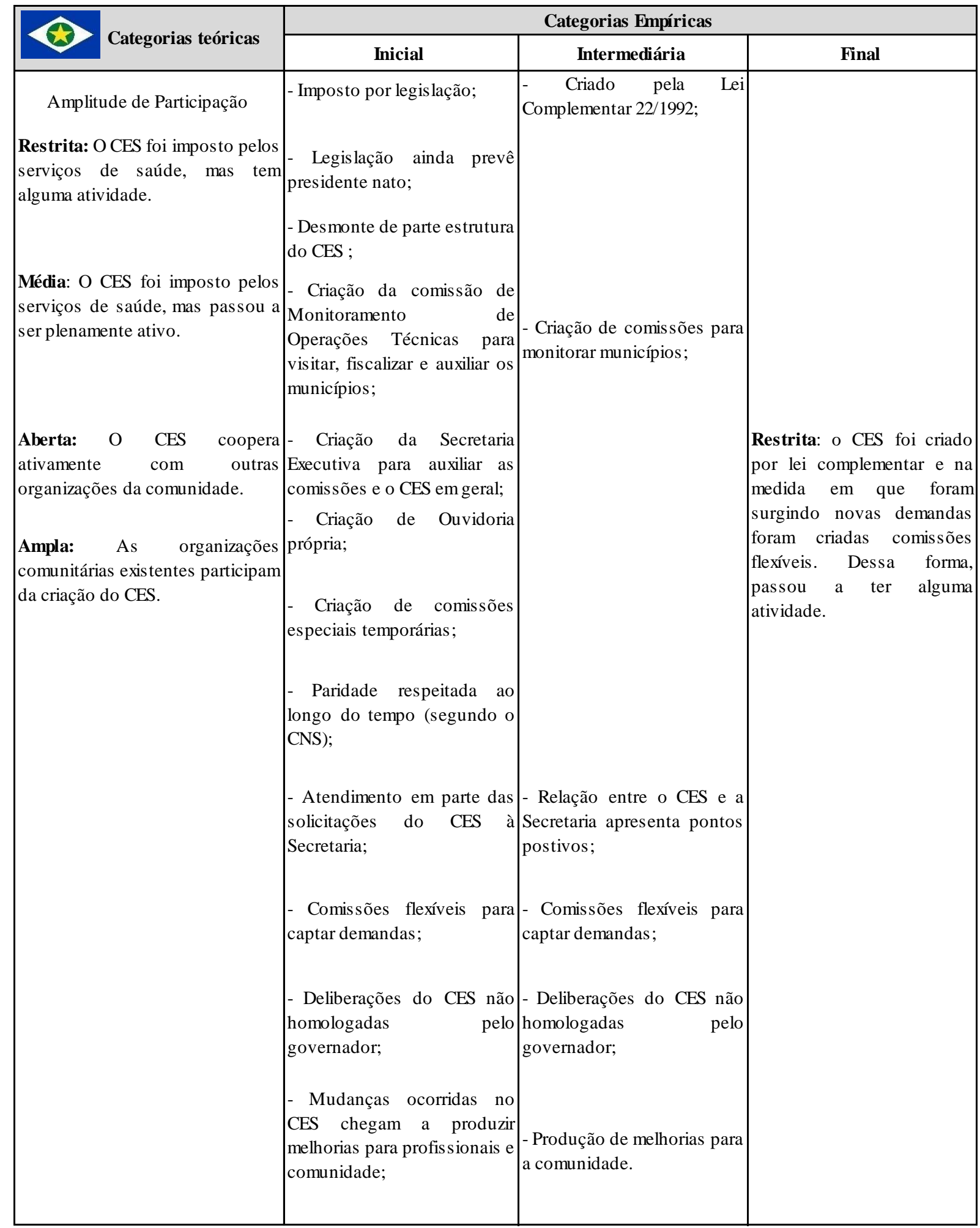

Quadro 14 - Categorização do indicador implantação e departamentalização - CES/MT.

Fonte: Baseado em Silva (1999). 


\subsubsection{Tradução das Demandas da Comunidade}

\subsection{Avaliação das Necessidades da Comunidade}

Para o CES/MT verificou-se que a avaliação das necessidades tende a ser aberta pelo fato de existirem múltiplas fontes responsáveis por identificar as demandas da comunidade, quais sejam: conselheiros - por meio de visitas em loco; questões levantadas por suas entidades representativas, Ouvidoria ${ }^{29}$ do CES, mídia e Comissão de Monitoramento - constituída especificamente para trabalhar em conjunto com os Conselhos Municipais nas demandas da saúde. Esses canais auxiliam o CES/MT a entender as necessidades da comunidade no sentido de avalia-las e discuti-las.

Ao analisar os meios de avaliação das necessidades dentro do CES a conselheira 04 (segmento usuários) considerou que "tem muitos canais para se chegar uma demanda no Conselho". No intuito de elucidar melhor essa questão o conselheiro 01 (segmento usuários) afirmou:

Tem as próprias observações que são pessoais (dos conselheiros), pois você passa o dia vivenciando isso. Temos as demandas que advêm da Ouvidoria do Conselho Estadual de Saúde, que são levadas às comissões. As comissões trabalham essas necessidades e chamam o gestor para equacioná-las de acordo com o planejamento pré-estabelecido. A partir do momento que essas demandas chegam na mão do conselheiro, ele ganha atribuição de correr atrás para fazer melhorar aquele indicador.

No trecho abordado é possível visualizar a participação dos próprios conselheiros na avaliação das necessidades, além do recebimento de demandas por parte da Ouvidoria do Conselho. A presença da Ouvidoria na estrutura do próprio CES é uma experiência nova para realidade desse tipo de instância participativa. De acordo com relatos dos conselheiros alguns Conselhos se utilizam da estrutura de Ouvidorias vinculada às Secretarias de Saúde e por conta disso não se tem um retrato fiel das necessidades da comunidade. $\mathrm{O}$ conselheiro 01 argumenta que "a ouvidoria [...] é quem mais observa as necessidades" e além disso "ela ouve o clamor da população, abrem-se os processos, faz-se a intermediação, não resolvendo, ela (demandada) vem para o plenário do Conselho, o mesmo atua e chama o gestor". O relato do conselheiro

\footnotetext{
${ }^{29}$ Instituída pelo Código Estadual 22/1992.
} 
denota que a Ouvidoria é um importante instrumento na avaliação das necessidades da comunidade.

Ademais, é necessário ressaltar que a categorização do indicador avaliação de necessidades vista como aberta também ocorre pelo fato das discussões serem levadas até as comissões e, por consequência, chegarem ao pleno, via parecer, no sentido de promover discussões e procurar dar resposta às demandas apresentadas. Isso seria um indício de que o Conselho busca representar ativamente o ponto de vista comunidade. A conselheira 05 (segmento trabalhadores) enfatiza a questão quando considera que "as demandas vão chegando [...] e vamos colocando na pauta e discutindo", pois para representar os anseios da comunidade em matéria de saúde é preciso saber quais são as necessidades e discuti-las no intuito de provocar melhorias.

Adicionalmente aos canais apresentados, cita-se a "outra estratégia no Conselho Estadual de Saúde que é a Comissão de Monitoramento. A gente monitora as unidades estaduais e faz cooperação técnica com os municípios [...] então acabamos tendo um perfil da realidade" conselheira 03 (segmento usuários). Outrossim, vale destacar mais um elemento para o fator de proximidade com as questões da comunidade, a partir do exposto pela conselheira 06 (segmento usuários) “como fazemos parte do movimento popular da Articulação Nacional dos Movimentos e Práticas da Educação Popular de Saúde (ANEPES) estamos muito próximos das práticas de cuidado que a população mantem" e "ultimamente estas necessidades são indicadas e pautadas por meio de movimentos que temos fora, que é a questão da falta de medicamento, a falta de médicos, a fila grande de espera, na regulação".

Outro ponto a ser destacado é a discussão de questões de aspetos relativos a áreas diversas da saúde como, por exemplo, o trânsito. Em relação a esse aspecto destaca-se que é preciso haver diálogo entre diversas áreas com finalidade de representar mais ativamente as diferentes necessidades da comunidade. É com esse pano de fundo que o conselheiro 01 (segmento usuários) aborda esse contexto afirmando que:

Uma das grandes preocupações que vão bater dentro da saúde são os casos externos. Acidente de automóvel, acidente com arma de fogo ou com arma branca, que acaba acontecendo e vindo parar aqui. Acidentes de trabalho, todos esses fatores, são condicionantes que acabam vindo parar aqui e onerando muito mais a saúde. Isso acaba sendo abordado dentro das discussões. Com isso temos que planejar junto a ajuda de outros setores para promover soluções por meio de comissões intersetoriais. Nós temos um trânsito solto e automaticamente nos teremos consequências maiores aqui na saúde 
[...] as variáveis da saúde vêm de todos os lados. Não é só a questão da doença que acomete o cidadão, mas também as causas externas que acontecem.

Face ao exposto, é apresentado o quadro 15 com a interpretação de que a avaliação de necessidades no Conselho Estadual de Saúde de Mato Grosso possui tendência aberta.

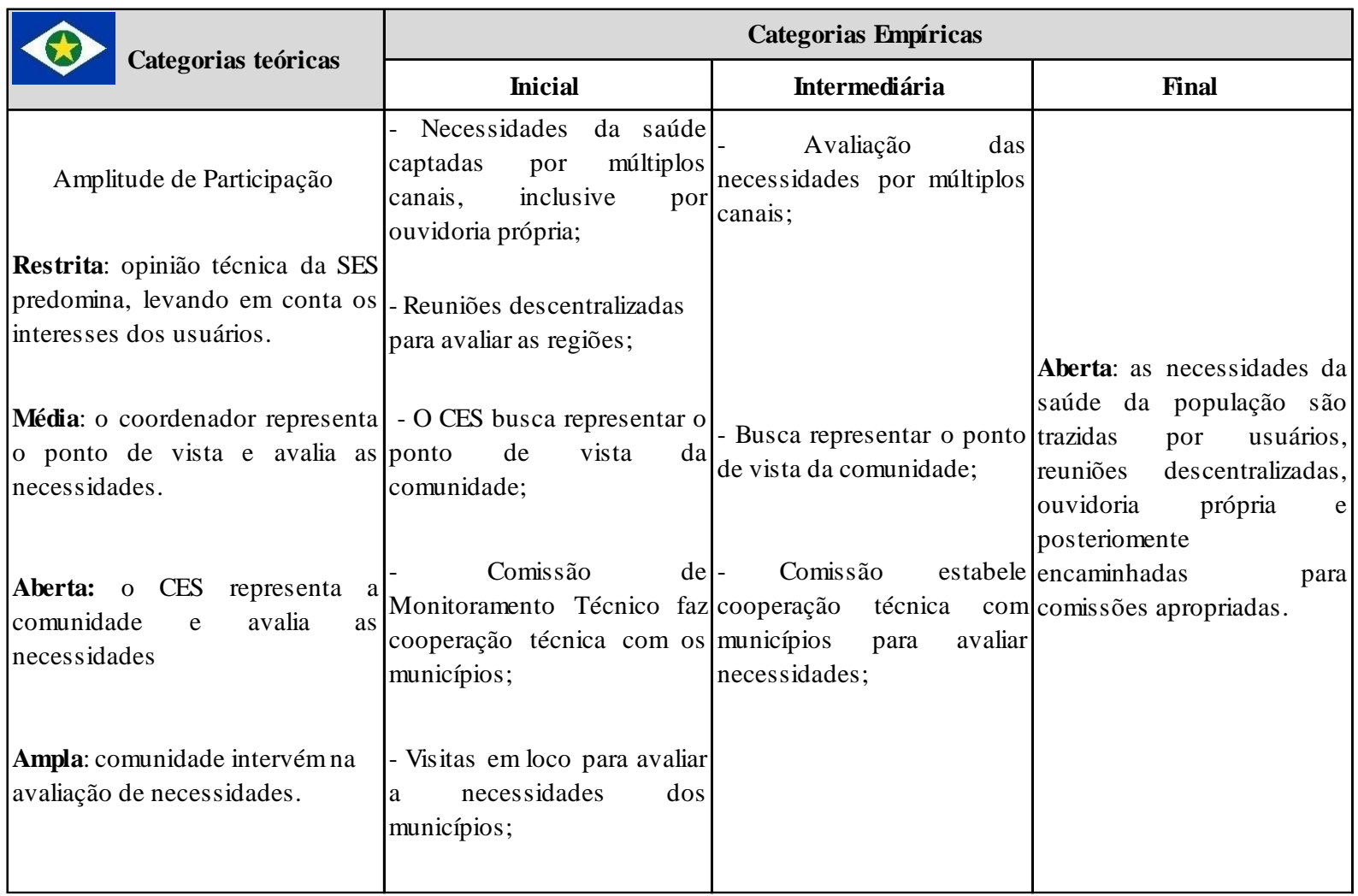

Quadro 15 - Categorização do indicador avaliação das necessidades da comunidade - CES/MT.

Fonte: Baseado em Silva (1999).

\subsection{Liderança}

Para o indicador liderança, a amplitude de participação tende a ser média, apesar de existir liderança de conselheiros representantes de movimentos populares, das demandas da comunidade serem atendidas, pelo menos em parte, e, por consequência, gerarem melhorias, bem como pelo CES representar o ponto de vista e avaliar as necessidades da comunidade, além de possuir conselheiros bem articulados. Acontece que, assim como em Goiás, as deliberações do CES não são homologadas pelo gestor da saúde, portanto, apresentado um cenário no qual o Conselho funciona sob um gestor estadual de saúde independente. 
Com o objetivo de destacar os aspectos positivos do indicador liderança no CES/MT é importante mencionar que das oito entrevistas analisadas todas afirmaram que a liderança na instituição participativa se dividia entre os segmentos usuários e trabalhadores, mas com preponderância dos primeiros. O conselheiro 01 (segmento usuário) aborda a questão ao afirmar:

A grande preponderância ainda é do usuário. Na liderança de fazer com que a política ande de forma mais específica. Eu acho que a responsabilidade é de todos, mas quem tem que se destacar mais no processo devem ser os usuários. Às vezes o trabalhador, que tem mais autonomia para falar em nome do próprio usuário, até mais do que o próprio governo.

A conselheira 05 (segmento trabalhadores) argumenta, ainda, que ao discutir as demandas da saúde nas comissões surgem, eventualmente, questões que motivam embates. Nestes casos “geralmente a proposta é deles (trabalhadores)". Isso confirma a participação dos trabalhadores da saúde no processo decisório do CES.

$\mathrm{O}$ atendimento às demandas da sociedade pode ser verificado como parcial. Ocorre que muitas das resoluções emitidas pelo CES no sentido de produzir melhorias na área da saúde não são homologadas pelo governo do Estado - o que apresenta interesses políticos incrustados na gestão da saúde. A conselheira 05 (segmento trabalhadores) aborda a questão afirmando:

A maioria das nossas resoluções deveria ser homologada pelo governador, muitas não
foram, inclusive, a derrubada das OS, que o Conselho por unanimidade derrubou e ainda
não foi homologada pelo governador. Apesar de tudo estamos tendo alguns ganhos,
conseguimos aprovar o concurso público que foi aprovado por unanimidade para que
houvesse em 2010. Não houve, mas após cobranças dos conselheiros haverá em 2015 .
Foi em Termo de Ajuste de Conduta (TAC), graças a denúncias que fizemos a nível
federal (MPF). Eu vejo o conselho como guerreiro, por conta deste desmonte que
houve, onde não tiveram respeito com nenhuma área dentro da saúde, inclusive com o
Conselho. (grifo do autor)

O relato da conselheira apresenta o que se chama de 'desmonte', segundo ela, promovido pelo governo do Estado no sentido coibir a atuação do Conselho (articulações políticas). Além disso, menciona que mesmo na dependência da homologação de resoluções por parte do governador, melhorias são produzidas pela atuação do Conselho. Entretanto, o fragmento que considera o Conselho guerreiro traz consigo um aspecto importante. $\mathrm{O}$ fato de uma constante luta para que as decisões do Conselho efetivamente sejam acatadas apresenta ambiente não participativo. Essa questão está ligada também ao não estabelecimento de uma relação de cooperação entre a gestão e o CES. Nesse sentido, entende-se que a tendência média é reforçada. 
Em outro aspecto, a conselheira 06 (segmento usuários) destaca a questão da representação de movimentos populares no Conselho. Como exemplo ela cita que boa parte dos conselheiros do segmento usuários integra o "movimento popular de saúde da Articulação Nacional dos Movimentos e Práticas em Educação Popular de Saúde (ANEPES)" e que com isso estão "muito próximos das práticas de cuidado que a população mantém”. Este também é um fator que representa parte da articulação dos conselheiros em atender às demandas da comunidade.

Por outro lado, destaca-se a existência de conselheiros vitalícios na estrutura do Conselho. O conselheiro 02 (segmento trabalhadores) ressalta a questão ao afirmar que existem "representatividades estanques que estão a mais de vinte anos e que a lei precisa ser reformulada". Novamente, verificou-se um fator que adensa a tendência média para a liderança. Após a realização de uma análise do tempo de experiência, ou seja, participação dos conselheiros na estrutura do Conselho de Saúde verificou-se que, em média, os mesmos possuem por volta de oito anos. Isso se deve, em parte, pelo fato de três conselheiros possuírem mais de 10 anos de experiência no exercício da atribuição de conselheiro de saúde, o que aumenta um pouco a média. Destaca-se, ainda, que o Conselho possui 22 anos existência e que o período médio de experiência, oito anos, representa cerca de $36 \%$ da trajetória do mesmo. Em relação aos aspectos levantados é possível afirmar que estes corroboram o relato feito pelo conselheiro 02, relativos às pessoas vitalícias. No que tange à reformulação do Conselho a legislação prevê a obrigatoriedade da renovação de pelo menos $30 \%$ da estrutura de conselheiros a cada mandato.

Sob esse prisma, o que se vê diante dos relatos das atas plenárias e das entrevistas realizadas é que esse cenário pode ser prejudicial na medida em que se forma uma espécie de “mandatário vitalício", pois não há preparação de um sucessor para as vagas de conselheiros (SILVA, 1999). O resultado é similar ao encontrado por Silva (1999). Para Demo (2001) isso pode ser justificado pelo fato de que os lideres acabam por se distanciar das bases no que se refere ao nível de conhecimento e atuação, dificultando, dessa forma, o processo de sucessão. $\mathrm{O}$ quadro 16 apresenta a categorização do indicador liderança. 


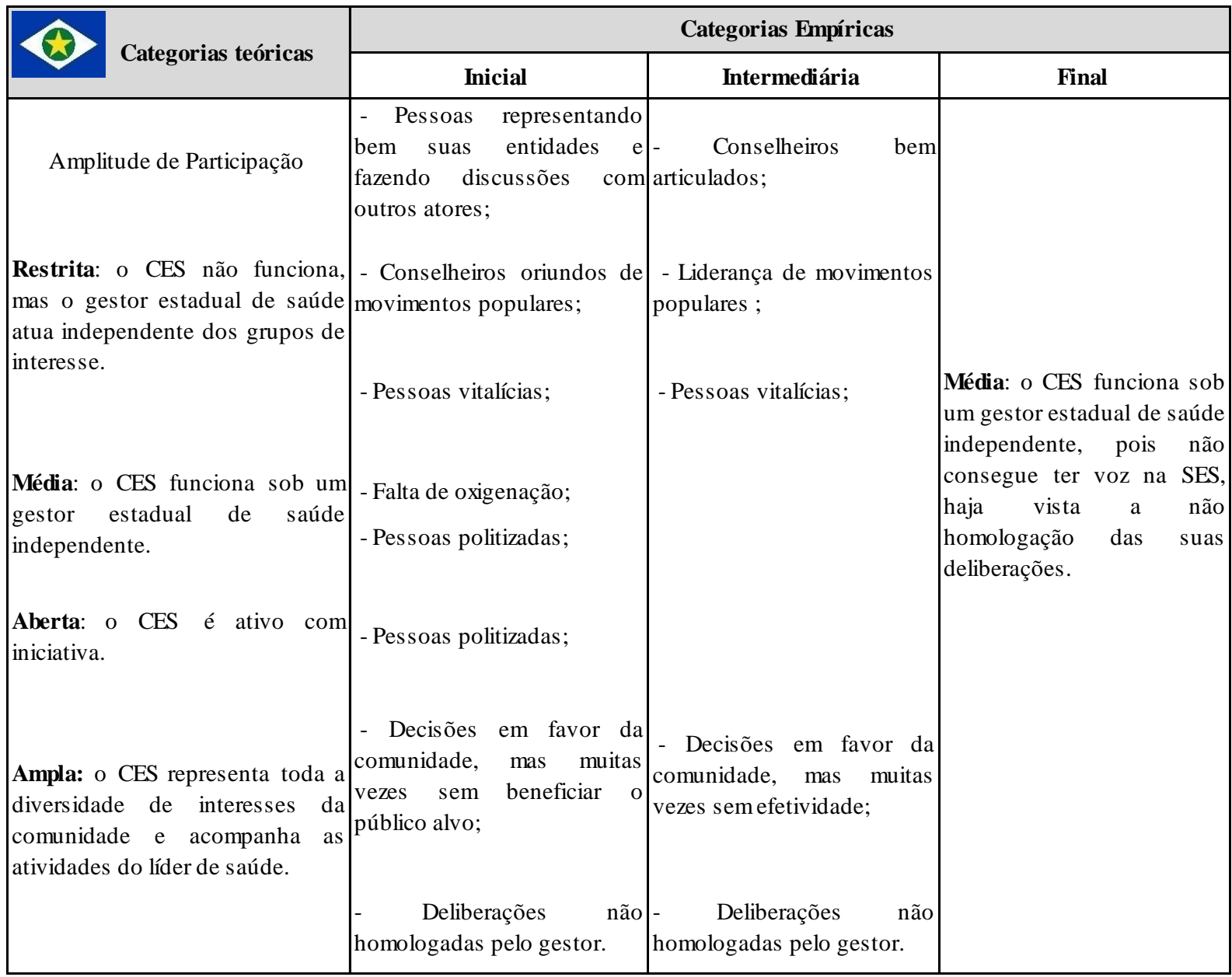

Quadro 16 - Categorização do indicador liderança - CES/MT.

Fonte: Baseado em Silva (1999)

\subsection{Mobilização de Recursos}

A amplitude do indicador mobilização de recursos foi considerada média. Ocorre que existem repasses periódicos de recursos da União, Estado e Municípios, porém a efetividade, chegada do recurso na ponta, muitas vezes é comprometida em virtude de cortes de recursos, remanejamentos realizados pelo gestor sem aprovação do CES e, por fim, licitações que muitas vezes são demoradas e acabam por comprometer a alocação de recursos em suas respectivas finalidades. A referida amplitude é fundamentada nas seguintes categorias intermediárias: "Estado repassa menos que os 12\% constitucionais", "Municípios com problemas no repasse", "Gestor apresenta contas de maneira parcial" e "A população acompanha a aplicação dos recursos".

Para o conselheiro 08 (segmento gestores) “o Estado repassa menos que os $12 \%$ constitucionais. Integro a comissão de prestação de contas e até hoje não cheguei a ver o 
montante constitucional ser aplicado de fato, além do que existem despesas que não são da saúde e estão lá (no relatório)". Soma-se aos argumentos do referido conselheiro - 08 - a abordagem do conselheiro 01 (segmento usuários) no tocante aos repasse de recursos:

Nós temos uma observação interessante neste quesito. No ano passado, no dia 28/12/2013, o governo do Estado emitiu uma nova lei no quesito de repasse de recursos aos municípios, reparcelando ele. Causando, assim, um caos na saúde dos municípios. Aquilo que está planejado, com certeza, tem que ser executado ou, se não executado, guardado para ano subsequente para ser feito posteriormente. É o que se estabelece em Lei de Responsabilidade Fiscal. Entretanto, há reclamações dos municípios no quesito repasse. Do Governo Federal, eu sei que vem com maior facilidade.

Já com respeito à fiscalização das ações do gestor via prestações de contas é importante frisar que o CES apenas acompanha a aplicação de recursos, pois a comunidade não participa no sentido de controlar os gastos da saúde. Vale também destacar que o ambiente é de menor fiscalização se comparado ao CES/GO, portanto, ainda sem a necessária intervenção (efetividade) para ser considerada como uma tendência aberta - na qual a população exerce controle sobre os recursos aplicados. Sobre esse aspecto, a conselheira 03 (segmento usuários) argumenta que a previsão para aplicação de recursos na área de saúde deve ser seguida, pois caso não seja cumprida o CES deve reprovar as contas do gestor - o que já aconteceu mais de uma vez. Dessa forma, verifica-se que não existe a figura do controle dos gastos, sobretudo pelo fato de haver necessidade de reprovações dos relatórios.

O Conselho tem que atuar diante do descumprimento deste recurso que está em lei. Então nós temos o relatório de gestão que se chama Relatório Anual de Gestão (RAG), e esse Relatório Anual de Gestão é o momento em que você olha se foram aplicados os recursos, dependendo da esfera que você está, municipal, estadual ou nacional. Se não cumpriu não pode aprovar o RAG. Em Mato Grosso nós não aprovamos o RAG, os últimos. (grifo do autor)

Por oportuno, cabe salientar que os recursos são repassados de maneira regular pelos entes federados, no entanto existem problemas com respeito à aplicação final dos recursos - de acordo com a previsão orçamentária. É preciso fazer uma distinção entre o repasse de recursos (financiamento das ações de saúde) e a efetiva destinação e aplicação dos recursos (sob responsabilidade do gestor da saúde). Com esse pano de fundo, verificou-se que no Estado de Mato Grosso existem eventuais problemas na aplicação dos recursos. A conselheira 05 (segmento trabalhadores) retrata parte desse cenário ao relatar "o que tem acontecido é que você faz uma previsão, uma programação e de repente no meio do mês vêm os cortes diminuindo os 
nossos recursos. A explicação que temos é que foi aplicada a famosa cota única ${ }^{30 "}$. De maneira complementar, a conselheira 06 (segmento usuários) afirma que "tem-se os recursos, mas na hora de executar não tem a licitação com transporte, alimentação, hospedagem. Acaba o recurso ficando parado". Essas informações somadas à questão das reprovações dos relatórios em virtude da sua qualidade da informação indicam que o gestor apenas "apresenta" contas da aplicação de recursos para a saúde, pois além de não haver controle de gastos por parte do CES a prestação de contas é feita de maneira parcial (qualidade das prestações de contas - seção 4.2 - apresenta sete variáveis com tendência restrita de um total de 13 avaliadas).

Por outro lado, o conselheiro 01 (segmento usuários) ao ser questionado com relação à aplicação de recursos de acordo com o PES informou que em determinados casos o gestor toma decisões de remanejar recursos sem anuência do CES - fato que descumpri a legislação. Questões como essas podem comprometer a execução do Plano. Nesse sentido, o mesmo - conselheiro 01 - aborda que é possível ocorrerem remanejamentos relativos às diretrizes do PES:

Desde que o gestor explique, mas muitas vezes já aconteceu. O fato ter tomado este desmando sem a anuência do Conselho. Quando se toma a consciência é hora de cobrar a responsabilidade de quem determinou sem a aprovação, seja o redirecionamento ou recondução do processo.

Diante do exposto, apresenta-se o quadro 17 o qual sintetiza os aspectos relativos ao indicador mobilização de recursos.

${ }^{30}$ A Cota Única é um instrumento utilizado pelo Estado de Mato Grosso para desvincular parte de recursos previamente orçados. 


\begin{tabular}{|c|c|c|c|}
\hline \multirow{2}{*}{ Categorias teóricas } & \multicolumn{3}{|c|}{ Categorias Empíricas } \\
\hline & Inicial & Intermediária & Final \\
\hline $\begin{array}{l}\text { Amplitude de Participação } \\
\text { Restrita: os recursos são } \\
\text { provenientes da prestação de } \\
\text { serviços. O CES não acompanha o } \\
\text { pagamento de honorários. } \\
\text { Média: contribuição periódica da } \\
\text { União, do Estado e do Município, } \\
\text { sem participação da comunidade } \\
\text { no acompanhamento dos gastos. } \\
\text { Aberta: contribuição periódica da } \\
\text { União, do Estado e do Município, } \\
\text { o CES acompanha a utilização dos } \\
\text { gastos. } \\
\text { Ampla: volume considerável de } \\
\text { recursos de origens diversas. O } \\
\text { CES decide a utilização dos } \\
\text { fundos. }\end{array}$ & 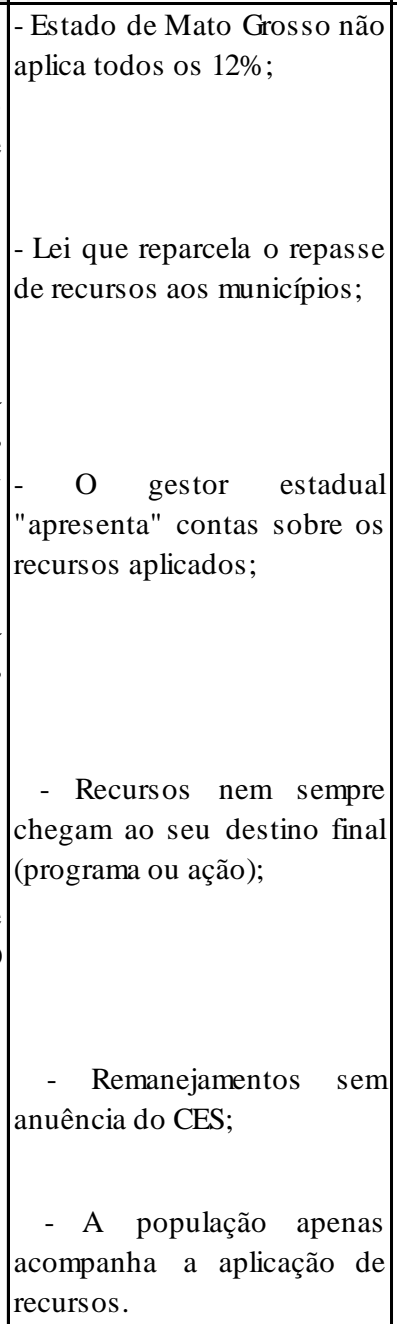 & $\begin{array}{l}\text { - Estado aplica percentual } \\
\text { inferior a } 12 \% \text {; } \\
\text { - Municípios com problemas } \\
\text { no repasse; } \\
\text { O gestor estadual } \\
\text { "apresenta" contas sobre os } \\
\text { recursos aplicados; } \\
\text { acompanha a aplicação de } \\
\text { recursos. }\end{array}$ & $\begin{array}{l}\text { Média: contribuição } \\
\text { periódica (mas fora dos } \\
\text { percentuais da EC 29/2000) } \\
\text { de recursos pelo Município, } \\
\text { Estado e União, em que a } \\
\text { comunidade não participa do } \\
\text { controle de gastos, apenas } \\
\text { acompanha. }\end{array}$ \\
\hline
\end{tabular}

Quadro 17 - Categorização do indicador mobilização de recursos - CES/MT.

Fonte: Baseado em Silva (1999).

\subsubsection{Amplitude de Participação Social da Comunidade no CES/MS}

A amplitude de participação social é composta por duas subdimensões. A primeira delas é a dimensão histórica que objetiva verificar questões relacionadas ao processo de implantação e departamentalização do Conselho, ou seja, como este se organiza em novas estruturas, como integra novos temas de saúde e que mudanças ocorreram desde a sua implantação (SILVA, 1999). A segunda subdimensão, tradução de demandas, na visão de se Silva (2005), busca avaliar as demandas da sociedade, inclusive como são recebidas e avaliadas 
pelo Conselho, bem como o tipo de liderança que figura neste cenário, além de verificar, também, a mobilização de recursos para atender às referidas demandas.

\subsubsection{Implantação e Departamentalização (Dimensão Histórica)}

A avaliação da dimensão histórica no Conselho Estadual de Saúde de Mato Grosso do Sul permitiu constatar que apenas três dos oito conselheiros entrevistados detinham conhecimento maior do momento da implantação ou vivenciaram alguma experiência que remetia àquela fase. O tempo de experiência no exercício das atribuições, em média, dos conselheiros entrevistados foi de 6,5 anos. Ao considerar um corte longitudinal de 26 anos de existência do Conselho a referida média de tempo apresenta necessidade de buscar outros meios para complementar a avaliação da dimensão histórica. Em outra via, destaca-se que o Conselho só possui atas disponíveis para o período de 2007 a 2013. Considerando que o mesmo foi criado em 1989 pelo Decreto ${ }^{\circ} 1595$ existe uma lacuna temporal não apresentada em documentos. Como dito anteriormente as atas são documentos importantes para que se possa entender como se dá e como ocorreu a atuação do Conselho ao longo do tempo. Com efeito, no caso do CES/MS também foi necessário realizar uma entrevista com o conselheiro, indicado pelo Conselho, que detinha maior conhecimento da perspectiva histórica da implantação e departamentalização, para que, então, fosse possível obter maiores informações sobre este indicador.

A implantação do CES/MS, na visão do conselheiro 09, o mais antigo - segmento usuários -, ocorreu em virtude de legislação e não houve envolvimento, pelo menos num primeiro momento, da sociedade civil organizada. Somente após a criação do mesmo as entidades integrantes do Conselho começaram buscar seu espaço, o que, por sua vez, instigou, após maior organização, a criação de comissões para estudar as necessidades da comunidade com a finalidade de auxiliar as decisões do CES. A categorização desse indicador possui tendência média, pois o CES foi imposto pelos serviços de saúde e depois passou a ser plenamente ativo. Vale mencionar que foram verificados indícios de cooperação com outras organizações da sociedade, contudo de forma pontual, não se configurando, portanto, em uma característica própria da instância participativa.

O conselheiro 09 (segmento usuários) destaca que as entidades representativas no momento da criação foram convidadas pelo governo, o que, na verdade, deveria ser feito por 
meio de edital, convocando interessados a participar. A motivação para a utilização do edital pode ser justificada justamente pelo fato adverso ocorrido no CES/MS, no qual foram indicadas entidades que detinham convênio com a Secretaria de Saúde, caracterizando, portanto, parcialidade nas deliberações do Conselho.

Com respeito aos primeiros conselheiros, na perspectiva do conselheiro 09, estes foram indicados pelas entidades. Além disso, os mesmos afirmavam pertencer ao segmento usuários, mas suas entidades, na verdade, tinham ligação (convênio) com o governo, o que os levaria a serem caracterizados como prestadores de serviço. Nesse sentido, a paridade na criação, aparentemente, não se mostrou adequada. É importante também citar o fato da legislação que criou o CES/MS ter considerado a figura do presidente nato - ponto posteriormente alterado. A existência do presidente nato é um fator que diminui a característica democrática dos Conselhos, pois pode haver viés por conta da participação do "Gestor" nas decisões. Por outro lado, vale ressaltar o esforço do Conselho em buscar maior articulação com outras entidades que estão inseridas no ambiente de controle social. A cooperação de outras instâncias de poder pode auxiliar no cumprimento das atribuições do próprio CES. Mesmo com a atuação do Conselho verifica-se que a população ainda não se sente parte integrante da gestão da saúde no Estado de Mato Grosso Sul. A justificativa está pautada no baixo interesse manifestado pela própria comunidade, que pode até ocorrer por falta de conhecimento da figura do Conselho ou mesmo do controle social. O conselheiro 09 apresenta alguns relatos que permeiam os aspectos mencionados.

\footnotetext{
Como ocorreu a implantação do conselho? De quem partiu esta iniciativa? Houve um envolvimento da população? No começo da década de 90, o Estado, por necessidade institucional e de legislação, foi quem organizou os conselhos tanto estaduais e também orientou os municipais. A lei de 1991, de criação do Conselho Estadual, foi criada pela a Secretaria de Saúde do Estado e convidadas as entidades para participar. Não tinha critérios de escolha de representação, inclusive, na lei de criação o presidente nato era o Secretário de Saúde do Estado. Então automaticamente quando trocava de secretário, trocava de presidente. No primeiro momento não houve o envolvimento da sociedade civil organizada para criar o Conselho. A situação foi melhorando a partir de 1994, 1995, principalmente quando o interior do Estado começou a participar junto com as pessoas de Campo Grande. Começou a se pensar um novo modelo e a atender o que previa na legislação, que desde 1990 diz que deveria ser escolhido entre os seus pares o presidente. E depois, por orientação do Conselho Nacional de Saúde, nós teríamos que além da escolha do presidente, a lei teria que ser mudada e só foi em 2003. A criação dos fóruns foi importante. Aí sim, a sociedade começa a se organizar em fóruns, fóruns de usuários. Todas as entidades representativas da sociedade usuárias do sistema escolhem os representantes que serão os titulares e suplentes do Conselho Estadual de Saúde.
} 
As entidades no início da criação do conselho foram convidadas. E eram entidades que tinham convênios com a secretaria e que na verdade não representavam de fato as instituições do segmento usuários. Eram entidades que mantinham convênios com a Secretaria de Estado de Saúde ou por parte do Governo e que eram beneficentes na época. Então para eles era muito mais fácil convidar estas instituições. Como as entidades eram todas ligadas ao Governo, todos os procedimentos que fossem discutidos no Conselho, logicamente, o governo teria sempre maioria. Porque jamais uma entidade que recebe dinheiro do Estado vai votar contra o projeto que ele coloca. Então é uma das coisas que por orientação do Conselho Nacional - e também a legislação diz isso - as entidades de usuários não podem ter vínculo com a Secretária de Saúde, porque se não caracteriza que a secretaria pode manobrar a hora que quiser.

De 2003 para cá a gente está conseguindo outro espaço que é interessante, a questão de começar a discutir com demais órgão de controle externo (MP, MPF, TC) no sentido de fazer um trabalho coletivo para forçar o executivo a fazer com que a legislação seja cumprida e, principalmente, as ações de saúde sejam contempladas com os recursos disponíveis. No caso do estado são 12\%. De 1997 para 1998 era 7\% do orçamento que era gasto em saúde. Chegamos no último ano com quase $9 \%$, apesar da lei dizer que tem que ser $12 \%$. Houve avanço. (Grifo referente a pergunta do pesquisador)

Você considera que ao longo do tempo a comunidade se reconheceu, como parte integrante do processo de gestão da saúde estadual? Na realidade a sociedade como um todo ainda não acompanhou o desdobramento do que representou o momento de lutas para a redemocratização do país na década de 80. Ela lutou para haver a redemocratização, lutou na $8^{a}$ Conferência, lutou para que houvesse um sistema com participação popular, só que quando saiu a lei a sociedade ficou muito apática e se acomodou. Ao longo do tempo a sociedade está começando a retomar esta questão. A sociedade ainda não se sente como elemento de decisão dos rumos tanto da saúde quanto da educação. Todos eles têm conselhos. A nossa discussão enquanto entidade é conseguir atingir a população no sentido de que ela venha cada vez mais para o Conselho e se sinta parte integrante do processo. (Grifo referente a pergunta do pesquisador)

Além dos elementos já mencionados a respeito da implantação do Conselho é importante citar também a criação de fóruns que se deu em 1997, após discussões realizadas na Conferência de Saúde, em 1995. Esses fóruns assumiram papel importante no controle social, pois discutiam e ainda discutem as necessidades da saúde de maneira mais próxima da sociedade e posteriormente levam suas decisões para o CES. A partir daí abre-se a discussão e quando é o caso as demandas são encaminhadas para as comissões adequadas. Por conseguinte, chega até o pleno um assunto já bastante discutido. Dessa forma, as deliberações do CES possuem maiores subsídios para atingir as demandas sociais da saúde. O conselheiro 09 (segmento usuários) aborda a referida discussão:

A partir de 1997, as entidades passaram a discutir dentro do fórum as ações. Porque funciona assim? O fórum se reúne uma vez por mês, antes da reunião do Conselho Estadual, para discutir a pauta e definir o que vai incluir de pauta. Então as entidades sentam, discutem e as que fazem parte do Conselho Estadual levam a decisão do fórum para ser discutida e deliberada dentro do Conselho. O que é de deliberação do Estado nós encaminhamos para o Estado executar. As que se referem a municípios nós 
passamos para a comissão, ela faz um parecer e orienta o município como se deve proceder.

No tocante à departamentalização do CES/MS cumpre-se mencionar a criação de comissões, bem como a capacidade destas em captar novas demandas da sociedade, ou seja, sua flexibilidade para recepcionar novos assuntos. Sob essa ótica, a conselheira 01 (segmento gestores) afirma "trabalhamos com comissões temáticas, permanentes. As comissões temáticas são criadas quando envolvem assuntos que não estão na rotina do Conselho; meio ambiente, criança/adolescente. Já as comissões permanentes tratam de toda a trajetória de atividade do Conselho". Adicionalmente, a conselheira 03 (segmento trabalhadores) ao ser questionada, quanto à capacidade do Conselho de criar novas comissões, respondeu:

\begin{abstract}
Sim, nesse momento, faço parte da comissão de DST AIDS. Criamos também em Corumbá uma associação de pessoas com a doença (Falciforme). Fez-se a proposta então de se criar essa comissão para essas doenças pouco conhecidas serem mais abordadas. As comissões existentes dentro do CES são flexíveis para captar novas demandas? Sim, a nossa comissão de Controle Social já recebeu várias demandas de outros assuntos, juntamente com a Comunicação, realizamos grupos de trabalho juntos, acredito eu que isso ajuda na melhoria do Conselho. (grifo referente a pergunta do pesquisador)
\end{abstract}

Ainda em relação à criação de comissões o conselheiro 09 (segmento usuários) adensa a questão ao mencionar que:

No início foram criadas quatro comissões técnicas, que eram obrigatórias. Era a do
Plano, do Financeiro, Controle Social e a de Recursos Humanos. Com a melhoria das
discussões dentro do Conselho, a partir de 1997 foram criadas outras comissões
permanentes dentro do Conselho. Se não me engano temos, hoje, seis ou sete comissões
permanentes. E aí temos algumas que foram agregando. Ex: a CIES, Comissão de Saúde
do Idoso, Criança. O governo foi criando programas para atender à demanda da
população e foi necessário criar comitês, comissões para fiscalizar esses serviços que
estavam sendo implantados.

O conselheiro 04 (segmento trabalhadores), no entanto, considera o fato de que "se criam muitas comissões [...] existem assuntos específicos que são momentâneos onde se pode criar grupos de trabalho para tirar o relatório e daí submeter ao pleno. Os assuntos são diversos, o que acaba tornando desnecessário criar comissões para cada um deles". Ademais, salienta-se a questão das mudanças ocorridas na estrutura do CES, na visão da conselheira 01 (segmento gestores) beneficiaram a comunidade. 
Beneficiam a partir do momento que se começa a discutir suas fragilidades. Porque antes o trabalhador não tinha espaço de discussão e hoje existe. O que a gente trabalha muito no Conselho é a própria formação do profissional. Que profissional queremos para o SUS. Então essas discussões se dão dentro do Conselho. O profissional que vem para o conselho tem outra visão do que é o SUS.

Ainda com relação aos benefícios para a comunidade a conselheira 05 (segmento usuários) argumenta: "eu acredito que pode ocorrer na maneira que o profissional é reconhecido, ele melhora seu atendimento. Ele vai atender a comunidade melhor". Adicionalmente, o conselheiro 04 (segmento trabalhadores) afirma que "essas mudanças que ocorrem no Conselho Estadual podem sim beneficiar a comunidade, quando você torna a máquina Conselho mais ativa, você consegue refletir mais à frente, que é a ponta, que é o usuário do SUS”. Todavia, para alcançar melhores benefícios "é preciso melhorar a questão da informação, os usuários precisão saber mais sobre seus direitos, para que haja uma melhor argumentação" conselheira 03 (segmento trabalhadores).

Por fim, ressalta-se a busca pela cooperação com outras organizações da comunidade. Na trajetória do CES existem indícios de que em determinados momentos o mesmo buscou estreitar relações com outras organizações da sociedade no sentido de atender às demandas da saúde. Para exemplificar o aspecto mencionado apresenta-se trecho retirado da ata plenária 260, de 29.06.2012, no qual a relatora de uma comissão apresenta a seguinte proposta para o Conselho:

\footnotetext{
Para o desenvolvimento de uma articulação intersetorial, a Relatora espera envolver em 2012 outras Instituições/Secretarias tais como: IPED/APAE, CEPPIR/Casa Civil, SETAS, INCRA., FUNASA, AGRAER, SESAI, Educação, Cultura, FUNDESPORTE, Universidades, Hospitais, Conselhos, Entidades Civis e Instituições que trabalham nos Movimentos Sociais. Tal trabalho seria feito com: ações educativas; sensibilização e capacitação de Profissionais de Saúde; "Quesitos Cor" nos Documentos e Sistemas de Informação do SUS - Documento Ministério da Saúde de 28/05/2003; Pré-Natal: Programa de Humanização do Pré-Natal e Nascimento; Programa de Anemia Falciforme, criado em 2000; Quilombolas - Portaria nº 1.434/2004-Ministério da Saúde-50\% ESF e SB; Parcerias - Religiões e Matriz Africana.
}

Todavia, o que foi possível constatar a respeito da cooperação com outras organizações da comunidade é que ainda são iniciativas pontuais, o que não permite, em princípio, afirmar que esta é uma característica incrustada no ambiente do CES. Portanto, a tendência aberta para o indicador em questão não foi contemplada. Após a exposição de argumentos acerca da avaliação da tendência do indicador implantação e departamentalização apresenta-se, no quadro 18, a sua categorização. 


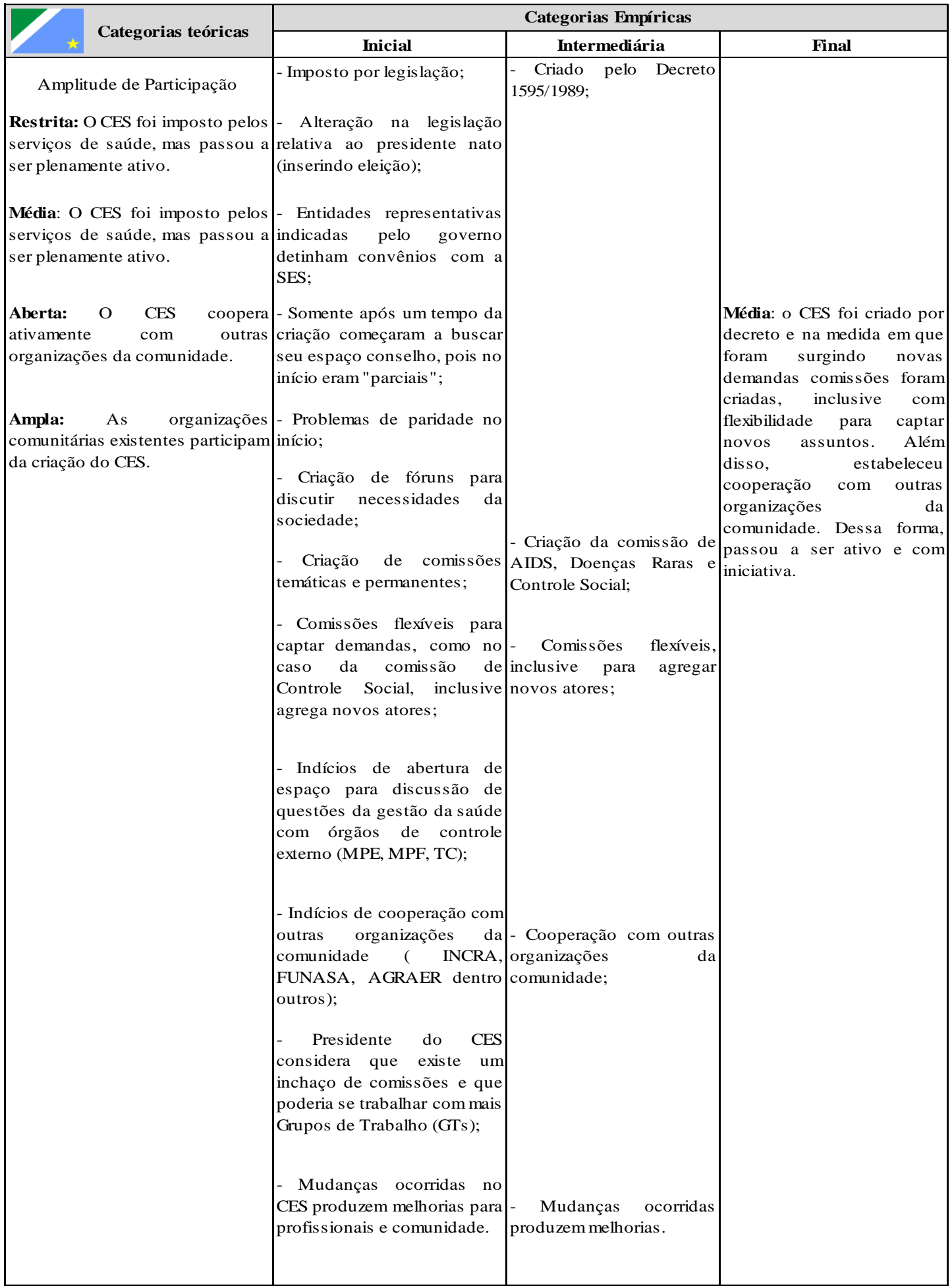

Quadro 18 - Categorização do indicador implantação e departamentalização - CES/MS.

Fonte: Baseado em Silva (1999). 


\subsubsection{Tradução das Demandas da Comunidade}

\subsection{Avaliação das Necessidades da Comunidade}

Para o CES/MS a amplitude do indicador avaliação das necessidades tende a ser aberta, também pelo fato de existirem múltiplas fontes responsáveis por identificar as demandas da comunidade - similar ao CES/MT. No caso do Conselho Estadual de Mato Grosso do Sul os canais para identificação das demandas estão ligados aos fóruns de usuários, trabalhadores e gestores da saúde, que discutem previamente as necessidades apresentadas por seus próprios integrantes ou até mesmo pelos usuários do SUS que entram em contato os mesmos. Nessa linha, a conselheira 03 (segmento trabalhadores) afirma que "as necessidades vêm como informações justamente da ponta, dos usuários que nós representamos”. Já a conselheira 06 (segmento usuários) afirma:

\footnotetext{
Nós temos os fóruns dos usuários, temos o conselho local dentro do hospital. Então as demandas chegam através dos próprios pacientes, por meio de denúncias, sugestões. Chegam demandas também dos municípios, pois cada conselheiro aqui é de um município e há reuniões descentralizadas onde os conselheiros trazem para o conselho o que foi discutido lá.
}

Ademais, cabe salientar que após as discussões nos fóruns as demandas são trazidas para o CES para que se possa, portanto, deliberar sobre qual seria a melhor forma de atende-las. Sobre esse aspecto a conselheira 03 (segmento trabalhadores) argumenta que "a comissão faz um estudo e mostra para nós, por meio de dados, relatórios de gestão, onde se encontra o erro ou acerto". $\mathrm{Na}$ fala da respectiva conselheira fica claro que após o encaminhamento das demandas para as comissões essas procuram fundamentar as questões apresentadas para que o pleno possa deliberar com maior conhecimento acerca das necessidades apresentadas.

Não obstante, destaca-se que os conselheiros estaduais integram e presidem os fóruns realizados, muitas vezes de maneira descentralizada (fora da capital), pois, dessa forma, se aproximam das reais necessidades dos municípios e trazem mais questões para discussão no CES. Outros meios de avaliar as necessidades estão ligados a veiculação de denúncias na própria 
mídia ou demandas advindas dos próprios municípios, bem como do próprio governo. A conselheira 05 (segmento usuários) aborda parte desse cenário:

A gente sempre faz uma avaliação entre um e outro e muitas vezes as demandas vem dos municípios ou o próprio governo mostra as reivindicações que chegam, e ele traz para o conselho como demanda e como proposta também. Por exemplo, aqui foi implantada a central de vagas. Ela veio por meio de uma demanda dos municípios pra cá. Com isso o governo negociou com o Ministério da Saúde e já têm uns cinco anos que está implantando e não terminou, mas a proposta é que funcione. Esta demanda foi discutida dentro do conselho.

Adicionalmente, também se toma como base os elementos inseridos nas diretrizes do Plano Estadual de Saúde, pois o foco do deste plano está alinhado às necessidades da população, isto é, direcionado a aplicar recursos no sentido de atender as demandas sociais da saúde. Segundo a conselheira 02 (segmento gestores) as necessidades são identificadas “primeiro pelo Plano Estadual de Saúde”. Por fim, é válido destacar que são discutidas questões relativas a áreas com educação, segurança dentre outras no CES. A justificativa é de que em algum momento as outras áreas geram implicações na saúde. Nessa linha, a conselheira 01 (segmentos gestores) afirma que somente é discutido aquilo "que compromete a questão da saúde. Por exemplo, os acidentes de trânsito que causam muitos atendimentos nos postos de saúde. A conselheira 06 (segmento usuários) complementa afirmando que esse cenário discussões além da área da saúde - "acaba envolvendo segurança, educação, entre outros”. 


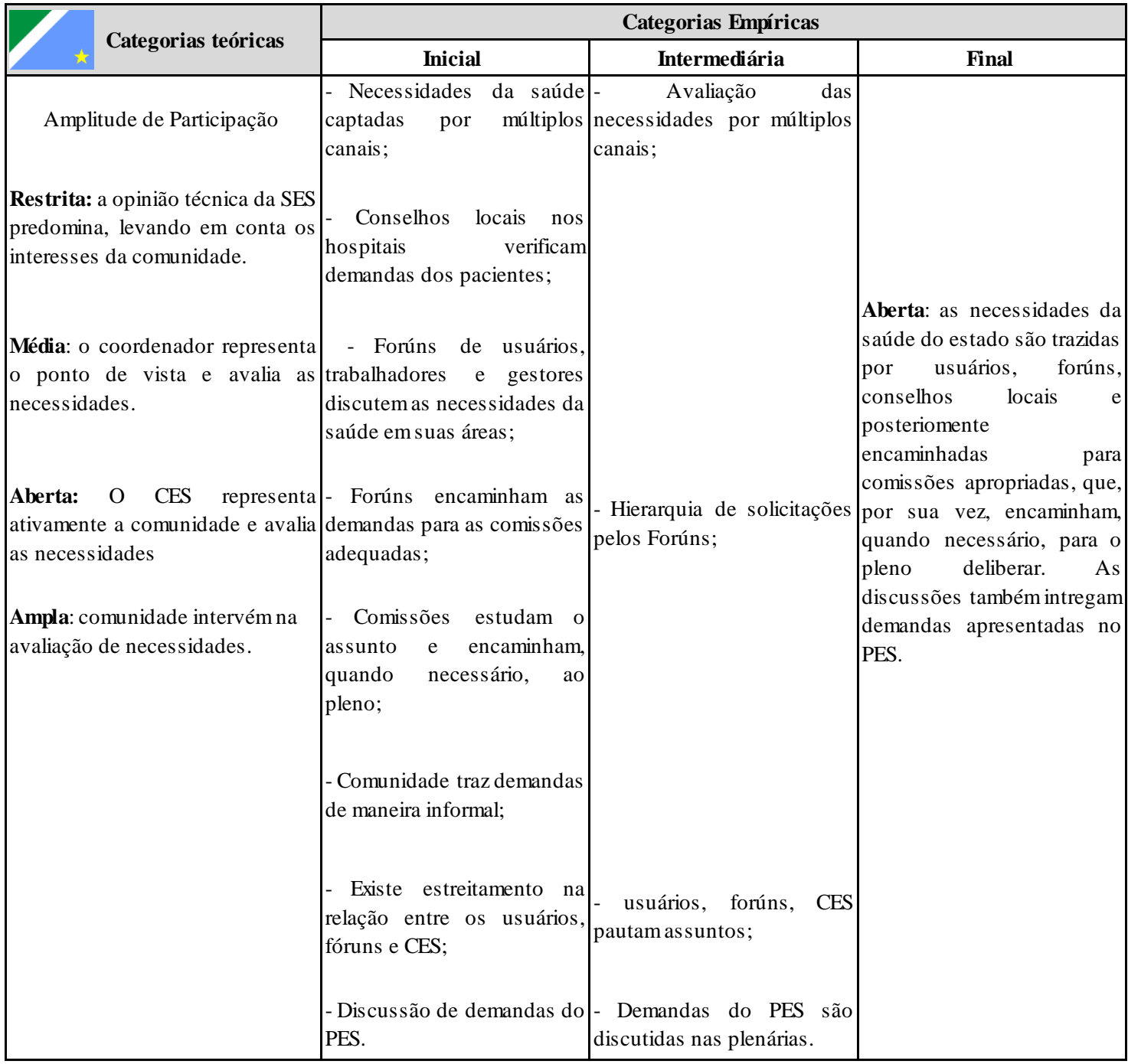

Quadro 19 - Categorização do indicador avaliação das necessidades - CES/MS.

Fonte: Baseado em Silva (1999).

\subsection{Liderança}

A amplitude do indicador liderança tende a ser média pelo fato do CES/MS funcionar sob um líder de saúde independente - o gestor -, o que desagua na não efetividade do Conselho. Portanto, o mesmo não pode ser classificado como ativo e com iniciativa (tendência aberta), apesar de possuir alguns aspectos alinhados a objetivos em prol da sociedade. Com efeito, a não efetividade ocorre principalmente pelo fato do gestor da saúde não acatar as decisões do Conselho Estadual. As categorias intermediárias que fundamentaram essa classificação são as seguintes: "Conselheiros bem articulados", "Líderes natos", "Pessoas vitalícias", "Decisões em favor da comunidade, mas efetividade", "Gestor não homologa as deliberações do CES" e a "liderança de movimentos populares". 
A existência de fóruns que representam os segmentos integrantes da estrutura do Conselho acabou se tornando uma ferramenta importante para que as necessidades da saúde do Estado pudessem ser apresentadas em reuniões descentralizadas, de modo a serem discutidas previamente para posterior encaminhamento para as comissões e plenárias do CES. Vale destacar que o presidente de cada fórum é eleito por seus pares e o principal critério considerado por eles se atem à questão da liderança praticada pelos indivíduos que se destacam. Dessa forma, fica exposta a existência de líderes natos, o que é confirmado pela afirmação do conselheiro 04 (segmento trabalhadores):

Cada segmento acaba tendo a sua liderança, lógico que o gestor é geralmente alguém ligado diretamente à secretaria. No trabalhador tem sempre a liderança em qualquer lugar. Como você se destacou se torna líder, então no meio do usuário tem lideranças antigas, e trabalhador também. No meio de 6 conselheiros titulares e 6 suplentes você identifica um ou dois que sempre estarão na liderança. Então na verdade eu não acredito que seja exercida (liderança) mais pelos trabalhadores, até porque o usuário é metade desse Conselho, mas sozinho ele não consegue tocar reuniões.

Ainda com respeito a fala do conselheiro é possível verificar que a liderança do Conselho está mais focada no segmento usuários, o que não impede a participação dos demais, conforme abordado. Por outro lado, é importante ressaltar um ponto ligado ao aspecto evidenciado no fragmento, no sentido de que algumas pessoas estão a mais tempo no Conselho. Com intuito de complementar a fala do conselheiro foi realizada uma análise do tempo de experiência, ou seja, participação dos conselheiros na estrutura do Conselho de Saúde e verificou-se que, em média, os mesmos possuem por volta de seis anos e meio. Dois dos conselheiros entrevistados possuem mais de 10 anos, similar ao ocorrido em Mato Grosso. Destaca-se, ainda, que o Conselho possui 26 anos existência e que o período médio de experiência, seis anos e meio, representa cerca de $25 \%$ da trajetória do Conselho. O fato de existirem pessoas vitalícias no Conselho pode representar aspectos negativos, pois evidencia a falta de oxigenação na instância participativa, pois não há preparação de novos conselheiros, sucessores (SILVA, 1999; DEMO, 2001).

É com esse pano de fundo que os conselheiros afirmam buscar responder às necessidades da comunidade. Todavia, na fala de sete dos oito conselheiros entrevistados as lideranças respondem parcialmente às necessidades. Isso se deve, em parte, ao fato do gestor não reconhecer a produção de melhorias que muitas vezes o CES tenta fazer. Para a conselheira 01 (segmento gestores) as decisões só produzem melhorias "quando reconhecida pelo gestor [...] mas normalmente o Conselho define, mas o gestor não aplica, pois só aplica o que a política 
governamental, partidária ou de grupo determina.”. A questão do gestor não aplicar o que foi preconizado pelo Conselho torna evidente a falta de efetividade deste.

Por fim, a conselheira 06 (segmento usuários) apresenta consideração acerca participação de lideranças de movimentos populares, por meio do fórum dos usuários e suas entidades representativas:

A liderança dos usuários, via entidades representativas, é maior porque eles são voluntários e as demandas chegam mais por eles. Nós temos um fórum dos usuários do SUS onde se faz uma reunião antes do Conselho Estadual sobre todas as demandas que vem da saúde.

Diante das características apresentas a categorização do indicador liderança é descrita no quadro 20.

\begin{tabular}{|c|c|c|c|}
\hline \multirow{2}{*}{ Categorias teóricas } & \multicolumn{3}{|c|}{ Categorias Empíricas } \\
\hline & Inicial & Intermediária & Final \\
\hline $\begin{array}{l}\text { Amplitude de Participação } \\
\text { Restrita: o CES não funciona, } \\
\text { mas o gestor estadual de saúde } \\
\text { atua independente dos grupos de } \\
\text { interesse. } \\
\text { Média: o CES funciona sob um } \\
\text { gestor estadual de saúde } \\
\text { independente. } \\
\text { Aberta: o CES é ativo com } \\
\text { iniciativa. } \\
\text { Ampla: o CES apresenta toda a } \\
\text { diversidade de interesses da } \\
\text { comunidade e controla as } \\
\text { atividades do gestor estadual de } \\
\text { saúde. }\end{array}$ & $\begin{array}{l}\text { - Conselheiros representando } \\
\text { fóruns; } \\
\text { - Fóruns representam a } \\
\text { comunidades; } \\
\text { - Líderes natos; } \\
\text { - Discussões que analisam o } \\
\text { todo (ações de saúde); } \\
\text { - Pessoas vitalícias; } \\
\text { - Persolanalis mo de alguns } \\
\text { conselheiros; } \\
\text { - Conselheiros com opinião } \\
\text { pessoal; } \\
\text { - Decisões em favor da } \\
\text { comunidade; } \\
\text { - Conselheiros atuantes; } \\
\text { - Visão dos líderes no } \\
\text { cumprimento das atribuições } \\
\text { do CES; } \\
\text { - Gestor não homologa as } \\
\text { deliberações do CES; } \\
\text { - Liderança de movimentos } \\
\text { populares. }\end{array}$ & $\begin{array}{l}\text { - Líderes natos; } \\
\\
\text { - Pessoas vitalícias; } \\
\\
\text { - Deliberações do CES } \\
\text { trazem benefícios para a } \\
\text { comunidade; } \\
\text { - Liderança de movimentos } \\
\text { populares. } \\
\text { - Gestor não homologa as } \\
\text { acrões do CES; }\end{array}$ & 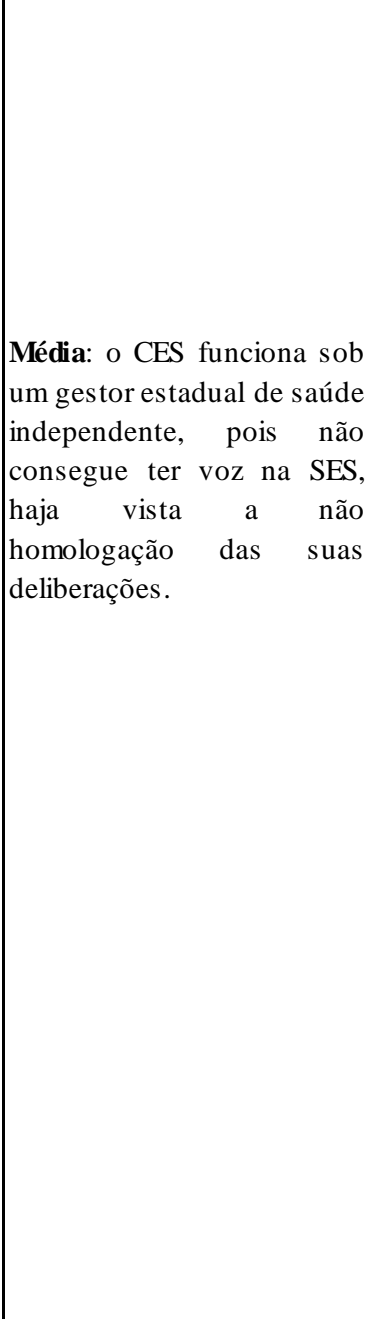 \\
\hline
\end{tabular}

Quadro 20 - Categorização do indicador liderança - CES/MS.

Fonte: Baseado em Silva (1999). 


\subsection{Mobilização de Recursos}

A avaliação do indicador mobilização de recursos apresentou tendência média pelo fato de existirem repasses periódicos de recursos da União, Estado e Municípios, mas sem a devida participação da comunidade no controle dos gastos da saúde. Vale lembrar que apesar dos recursos serem repassados periodicamente existem problemas relativos aos percentuais constitucionais (EC 29/2000). A referida amplitude é fundamentada nas seguintes categorias intermediárias: "Estado aplica percentual inferior aos 12\%”, "Municípios aplicam de 20\% a $25 \%$ por conta do Estado aplicar menos de 12\%", "Gestor apenas apresenta contas ao CES" e a "População apenas acompanha a aplicação de recursos". A conselheira 01 (segmento gestores) apresenta sua consideração no quesito repasse de recursos advindos dos entes federativos envolvidos na gestão da saúde:

Temos as discussões no âmbito do Município, do Estado, da União. O Município, historicamente, gasta muito mais do que a legislação estabelece. Nós temos Municípios que gastam de $20 \%$ a $25 \%$ de suas receitas com a saúde. Os Estados nunca aplicam os $12 \%$, não é só Mato Grosso do Sul, não. E a União não tem uma definição de quanto por cento é dela. Não está claro isso, não tem como você cobrar dela.

Nota-se que a distribuição de recursos apresenta irregularidade com respeito ao repasse de cada ente federado, pois os municípios acabam sendo sobrecarregados com aplicação de recursos para a saúde. Com esse pano de fundo é possível visualizar que o Estado e a União, apesar de fazerem repasses, não estão atendendo, em termos financeiros, às necessidades dos municípios. Como relatado em relatório do TCE/MS ${ }^{31}$ o repasse por parte do Estado gira em torno de $8 \%$, com despesas efetivas de saúde, quando deveria ser $12 \%$. Mesmo que fosse aplicado o teto ainda seriam necessários mais recursos, tendo em vista que os municípios chegam a gastar 25\% de suas receitas com saúde (quando deveriam aplicar apenas 15\%). Para conselheira 03 (segmento usuários) “o recurso federal é repassado”. Contudo, na fala de todos os conselheiros ficou claro que os recursos ainda não são suficientes, o que prejudica o atendimento dos anseios da sociedade em matérias de gastos com saúde. A reivindicação mais

\footnotetext{
${ }^{31}$ Para maior detalhamento ver < http://www.campograndenews.com.br/cidades/lei-do-rateio-e-falhas-na-gestaomantem-dor-e-caos-na-saude $>$.
} 
abordada, por parte dos conselheiros, nesse aspecto faz referência ao movimento Saúde $+10^{32}$, justamente para complementar aquilo que é repassado pela união.

Outro ponto a ser destacado é a Lei 2.261/2001 que disciplina o rateio de despesas e os custos entre os vários da administração direta, fundações e autarquias. No Mato Grosso do Sul é conhecida como Lei do Rateio. Em linhas gerais a referida lei permite a alocação de recursos da saúde em outras finalidades (despesas que não são da saúde). O presidente do Conselho de Secretárias Municipais de Saúde (COSEM/MS), Frederico Marcondes Serrano, em entrevista $^{33}$ concedida a um jornal eletrônico de Campo Grande afirmou que são retirados recursos da saúde para se aplicar em outras coisas. Além disso, estima que foram retirados da saúde cerca de RS 200 milhões de recursos desde o governo de 1999 - o de José Orcírio Miranda dos Santos.

A ocorrência de questões como essas apresenta um cenário no qual se admite a aplicação de percentuais inferiores aos $12 \%$ constitucionais sob responsabilidade do Estado. Em relação a isso cita-se ainda o relatório de Auditoria de Desempenho Operacional elaborado pelo TCE/MS, mencionado ainda na entrevista do jornal eletrônico, sob reponsabilidade da conselheira Marisa Serrano, que apesar da SES/MS ter apontado em determinado momento que aplicava $12,5 \%$ para a saúde, foi apurado pelo tribunal que apenas $8,44 \%$ efetivamente se tratava de despesas com saúde, em 2013.

Adicionalmente, o conselheiro 05 (segmento trabalhadores) argumenta que "existe a previsão, mas nós, membros do Conselho, não fazemos parte dessa discussão na integra, quando chega algo até a gente, tomamos algumas decisões, mas muitas vezes não são acatadas”. Fica claro pela fala do presidente do CES que mesmo existindo o repasse de recursos, seja pela União, Estado ou Município, o mesmo não as integra as discussões de maneira participativa, provavelmente por conta de questões políticas envolvidas na execução dos recursos financeiros aplicados na área de saúde, bem como a Lei do Rateio. Soma-se a isso uma eventual consequência: as sugestões do CES não serem acatadas pelo gestor, tampouco justificadas de maneira adequada quando são apontados focos de melhoria na execução do recurso e não são dadas respostas a esse respeito.

\footnotetext{
${ }^{32}$ Ver maiores informações em < http://www.saudemaisdez.org.br >.

${ }^{33}$ Para maior detalhamento ver < http://www.campograndenews.com.br/cidades/lei-do-rateio-e-falhas-na-gestaomantem-dor-e-caos-na-saude $>$.
} 
O Conselho apenas acompanha a aplicação dos recursos financeiros na área de saúde, a partir dos Relatórios Quadrimestrais e Anuais de Gestão. A utilização do termo "acompanha" se justifica pelo fato de não haver controle efetivo da destinação dos recursos da saúde, haja vista o fato do governador muitas vezes não acatar a deliberações do CES, que inclusive se referem também à aplicação dos recursos. A conselheira 03 (segmento trabalhadores) afirma que:

Os relatórios de gestão a nível Estadual mostram que nem sempre o que está previsto para se investir, é investido. Quando não há investimento, quem sofre mais consequências são os Municípios, pelo fato de o recurso não ser investido do jeito que deveria ser, com a devida comprovação das comissões do Conselho.

O fragmento aborda duas perspectivas importantes. A primeira delas se refere a participação do Conselho em acompanhar a aplicação dos recursos da saúde e apurar que, em geral, aquilo que é previsto não é necessariamente aplicado. Além disso - segunda perspectiva - vale lembrar que para se chegar a referida constatação é preciso pelo menos que as contas sejam apresentadas pelo gestor. Todavia, o ato de prestar contas também se remete à responsabilidade do gestor público sobre a maneira com os gastos são realizados - conforme discussão de accountability da plataforma teórica. Diante disso, verificou-se que o gestor não presta conta de sua gestão de maneira a atender às reivindicações do CES, pois não homologa suas deliberações, ou seja, não assume de fato a responsabilidade de atender às necessidades da comunidade em determinados aspectos. Diante das razões expendidas, o quadro 13 apresenta a tendência deste indicador - mobilização de recursos. 


\begin{tabular}{|c|c|c|c|}
\hline \multirow{2}{*}{ Categorias teóricas } & \multicolumn{3}{|c|}{ Categorias Empíricas } \\
\hline & Inicial & Intermediária & Final \\
\hline Amplitude de Participação & $\begin{array}{l}\text { - Estado de Mato Grosso do } \\
\text { Sul não aplica todos os } 12 \% \text {; }\end{array}$ & $\begin{array}{l}\text { - Estado aplica percentual } \\
\text { inferior a } 12 \%\end{array}$ & \\
\hline $\begin{array}{l}\text { Média: contribuição periódica da } \\
\text { União, do Estado e do Município, } \\
\text { sem participação da comunidade } \\
\text { no acompanhamento dos gastos. }\end{array}$ & $\begin{array}{l}\text { - Municípios que gastam de } \\
20 \% \text { a } 25 \% \text { de suas receitas } \\
\text { com a saúde por conta do } \\
\text { Estado aplicar menos de } \\
12 \% \text {; } \\
\text { - O gestor estadual apenas } \\
\text { apresenta contas sobre os } \\
\text { recursos aplicados; }\end{array}$ & $\begin{array}{l}\text { - Municípios que gastam } \\
\text { de } 20 \% \text { a } 25 \% \text { de suas } \\
\text { receitas com a saúde por } \\
\text { conta do Estado aplicar } \\
\text { menos de } 12 \% \text {; } \\
\text { - Gestor apenas apresenta } \\
\text { contas ao CES; }\end{array}$ & $\begin{array}{l}\text { Média: o CES funciona sob } \\
\text { um gestor estadual de saúde } \\
\text { independente, pois não } \\
\text { consegue ser efetivo, haja } \\
\text { vista a não homologação } \\
\text { das suas deliberações. }\end{array}$ \\
\hline $\begin{array}{l}\text { Aberta: contribuição periódica da } \\
\text { União, do Estado e do Município, } \\
\text { o CES acompanha a utilização dos } \\
\text { gastos. } \\
\text { Ampla: volume considerável de } \\
\text { recursos de origens diversas. O } \\
\text { CES decide a utilização dos } \\
\text { fundos. }\end{array}$ & $\begin{array}{l}\text { - A população apenas } \\
\text { acompanha a aplicação de } \\
\text { recursos; } \\
\text { - Leio do rateio provoca } \\
\text { dificuldades no repasse de } \\
\text { recursos. }\end{array}$ & $\begin{array}{l}\text { - A população apenas } \\
\text { acompanha a aplicação de } \\
\text { recursos; }\end{array}$ & \\
\hline
\end{tabular}

Quadro 21 - Categorização do indicador mobilização de recursos financeiros - CES/MS.

Fonte: Baseado em Silva (1999).

\subsubsection{Discussão dos resultados da amplitude de participação nos CES da Região Centro Oeste}

A tendência de amplitude de participação dos indicadores analisados nos Conselhos Estaduais de Saúde de Goiás, Mato Grosso e Mato Grosso do Sul estão apresentadas no gráfico 01 . 
Amplitude de Participação - CES Centro Oeste

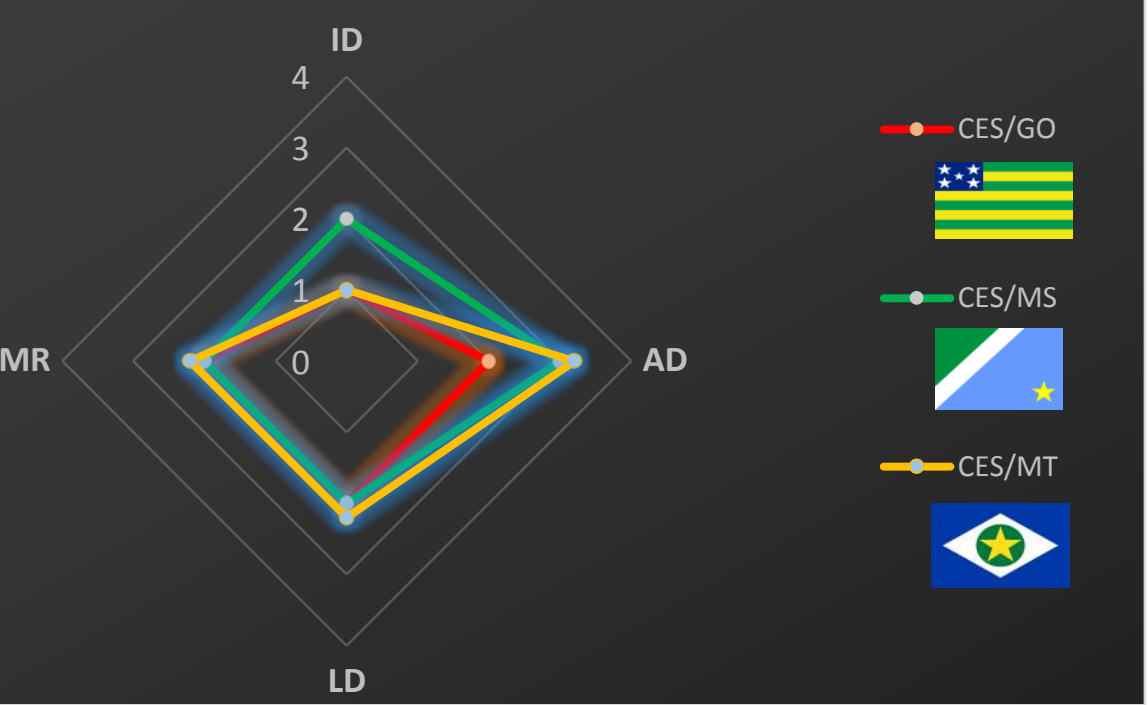

Gráfico 1 - Tendência dos indicadores de amplitude de participação dos CES.

Fonte: elaborado pelo autor.

$\begin{array}{ll}\text { Legenda } & \text { Legenda } \\ \text { ID - Implantação } & 1 \text { - Restrita } \\ \text { AD - Avaliação das Necessidades } & 2-\text { Média } \\ \text { LD - Liderança } & 3 \text { - Aberta } \\ \text { MR - Mobilização de Recursos } & 4-\text { Ampla }\end{array}$

De forma geral é possível visualizar a partir do gráfico apresentado que os indicadores apresentaram comportamento similar para avaliação das necessidades, liderança $\mathrm{e}$ mobilização de recursos, nos três Conselhos Estaduais de Saúde como tendência média. A exceção ocorre em virtude do indicador implantação e departamentalização, pois no caso de Mato Grosso do Sul o CES foi implantado pelos serviços de saúde, mas passou a ser plenamente ativo - tendência média. No entanto, cumpre-se mencionar de forma mais específica determinados pontos relativos aos indicadores mencionados para os três Conselhos.

Com respeito à criação dos Conselhos destaca-se a importância de se construir um ambiente para que os mesmos possam funcionar sob o esqueleto de uma sociedade civil organizada - em torno das questões da saúde. A apresentação dos cinco $^{34}$ canais participação elencados por Demo (2001) considera um canal que pode ser representado pela figura de um Conselho de Saúde, pois nesta instância deve existir a organização da sociedade civil (um dos canais elencados pelo autor). Para Copatti (2010):

\footnotetext{
${ }^{34}$ Organização da sociedade civil, cultura como processo de identificação comunitária, planejamento participativo, educação como formação à cidadania e, por fim, o processo de conquista de direitos (DEMO, 2001)
} 
A organização da sociedade reporta-se à capacidade de assumir formas conscientes, para ter conhecimento de quais são os seus reais interesses, e não apenas interesses de grupos que apenas querem mostrar o seu domínio sobre uma sociedade qualquer. Além de formas conscientes, é preciso que haja políticas de organização para que se possam reduzir os conflitos e as desigualdades que são sentidas principalmente em um âmbito local.

A visão apresentada pela autora se encaixa no contexto dos Conselhos de Saúde na medida em que se considera que a sociedade deve se organizar de modo a avaliar e acompanhar as necessidades da saúde. O sentido é sempre buscar se adequar às demandas da comunidade. Dessa forma, além do aspecto da forma de implantação do Conselho é preciso considerar como este se estrutura no sentido de construir o esqueleto da sociedade civil organizada, citado anteriormente.

Sob essa ótica, a análise do indicador implantação $e$ departamentalização apresentou similaridade para os Conselhos Estaduais de Saúde de Goiás e Mato Grosso. A tendência do indicador para os referidos Conselhos Estaduais foi considerada restrita. No intuito de justificar a tendência argumenta-se que os Conselhos foram impostos por legislação, e posteriormente passaram a ter alguma atividade. Em ambos os casos o envolvimento da sociedade na implantação dos Conselhos não se mostrou efetivo a ponto reivindicar a criação dos mesmos. No caso de Mato Grosso do Sul a tendência para o indicador implantação e departamentalização foi considerada média, em virtude do CES ter sido imposto num primeiro momento, mas ter passado a ser plenamente ativo. Resultado similar foi encontrado na pesquisa realizada por Silva (2005, p. 114) relativo ao Conselho Municipal de Saúde de Porto Alegre. A autora considera que para o CMS/POA a categorização "tende a ter uma amplitude de participação classificada, segundo as categorias teóricas, como média, uma vez que foi criado por lei e à medida que surgem novos assuntos organiza-se uma comissão ou grupo para estudar o tema".

Ainda com relação ao Conselho Estadual de Saúde de Mato Grosso do Sul e sua tendência média, a população chegou a acompanhar a criação e até participar das discussões, mas sem culminar na criação do mesmo. Logo, o Conselho também acabou sendo implantado por imposição legal. Todavia, o que o diferencia dos demais é que este, em momentos, pontuais passou a cooperar com outras organizações da comunidade, a exemplo de universidades federais, FUNASA, entidades civis que trabalham com movimentos sociais dentre outros. Sobre essa perspectiva de cooperação Copatti (2010) afirma que: 
O exercício da cidadania se torna completo quando os cidadãos podem participar na definição dos rumos da sociedade e também quando podem co-responsabilizar-se pelas ações públicas, utilizando a cooperação e ajuda mútua entre instituições públicas, privadas, não-governamentais e pessoas voluntárias, fortalecendo o desenvolvimento local. (grifo do autor)

Por fim, em relação ao indicador implantação e departamentalização, relembra-se o pensamento levantado por Copatti (2010) - o Conselho deve se estruturar no sentido de construir o esqueleto da sociedade civil organizada - pelo fato deste instigar reflexão relacionada, dentre outros, relacionada à ausência de controle e fiscalização por parte dos Conselhos (de forma mais acentuada para Goiás e Mato Grosso). Guerreiro (1992, p. 2) aponta que "a gestão corresponde analiticamente ao processo de planejar, executar e controlar. Os gestores portanto não devem se limitar apenas à execução das atividades sob sua responsabilidade, mas também planeja-las e controla-las”. No caso da gestão da saúde também não se pode furtar aos preceitos elencados, sob pena de ocorrer o que, de fato, se verifica nos Conselhos de Goiás e Mato Grosso, um distanciamento destas instâncias participativas em relação ao que está acontecendo do dia a dia da saúde. Logo, ao se considerar como foco a gestão é possível idealizar que se houvesse coordenação de planejamento, execução e controle a questão mencionada sobre devolução de recursos (especificamente para o caso de Goiás) não ocorreria, assim como outros problemas derivados desse cenário.

O indicador avaliação das necessidades apresentou tendência aberta em Mato Grosso e Mato Grosso do sul, restando a Goiás apenas a representação do ponto de vista das necessidades da comunidade, ao passo que nos outros casos o CES representa esta. Uma das principais características motivadoras da tendência aberta tem como base a questão dos Conselhos possuírem múltiplos canais para avaliar quais são as necessidades da população em seus respectivos Estados. Dentre essas é possível destacar a avaliação das necessidades a partir dos conselheiros, comissões de monitoramento, mídia, ouvidoria, conselhos locais, fóruns, conferencias regionais, planos de trabalho das secretarias, Planos Estaduais de Saúde dentre outros. Para Silva (2005) o indicador avaliação das necessidades possibilita que se enxergue o fato das pessoas intervirem no planejamento ou diagnóstico da saúde. Tendo como referência a ótica apresentada pela autora é possível perceber que no caso de Mato Grosso e Mato Grosso do Sul a comunidade pode participar de maneira direta ou indireta do planejamento ou diagnóstico. Para Goiás existe a questão da Mesa Diretora, na figura da Secretaria Executiva, encaminhar as 
discussões das comissões, o que de certa, desconfigura o caráter de autonomia das comissões de discutir, encaminhar e acompanhar seus despachos.

Como exemplo da intervenção direta dos usuários da saúde cita-se o caso dos conselhos locais de Mato Grosso do Sul que estão inseridos também em hospitais da rede pública. Os relatos das entrevistas demostraram que os pacientes poderiam pedir pauta para as discussões do CES - a partir de reclamações ou sugestões. Com respeito à intervenção indireta se tem, por exemplo, as questões abordadas no Plano Anual de Trabalho da Secretaria de Saúde que são discutidas pelo Conselho como necessidades da comunidade, previamente levantadas pelo governo. Por outro lado, destaca-se a questão dos Conselhos estabelecerem hierarquia de prioridades na avaliação das demandas da saúde - característica encontrada por Silva (1999) no Conselho Municipal de Saúde de Porto Alegre. A referida hierarquia é importante para os Conselhos, pois filtra as demandas de modo a avaliar as suas prioridades e, por consequência, destiná-la às comissões adequadas, quando necessário. A partir dos canais de avaliação das necessidades da comunidade e da maneira como estas são tratadas pelos Conselhos, de maneira geral, é possível considerar que os mesmos representam os anseios da comunidade pelo fato de conhecerem as suas necessidades (características da tendência $a b e r t a)$.

Em relação ao indicador liderança e sua tendência aberta parte-se da visão de Likert (1975) sobre o sistema consultivo em que a liderança estabelece uma relação de confiança entre os membros, inclusive indicando apoio dos líderes aos demais nas decisões que são tomadas pelo grupo. Ainda nessa linha Likert (1979) argumenta que existe comunicação entre o que ele denomina de escalões mais altos e mais baixos. Para o caso dos Conselhos de Saúde o que poderia ser chamado de escalão mais alto seriam as discussões das plenárias para debater sobre as decisões da instância participativa, no que se refere às necessidades de saúde da população. Em relação ao escalão mais baixo pode-se considerar a figura do conselheiro, de forma individual ou em pequenos grupos, e sua respectiva atuação em conformidade com as perspectivas das entidades as quais representam, bem como as discussões das necessidades da saúde nas comissões e grupos de trabalho. Nesse cenário ficou demonstrado nos Conselhos que existem lideranças, principalmente dos segmentos usuários e trabalhadores, que orientam tanto as discussões das comissões quanto ao processo decisório das reuniões plenárias - a partir de contribuições realizadas.

Demo (2001) considera que existem líderes à medida em que se apresentam de maneira muito natural, que não fazem esforços para revelar características de comando. Sob essa 
ótica, foi possível perceber que os Conselhos possuem indivíduos com essa característica, ora com o presidente do CES, ora com demais conselheiros - no caso do CES/MS com um representante do segmento usuários. Com efeito, os Conselhos de Goiás, Mato Grosso e Mato Grosso do Sul apresentam líderes natos que inclusive representam movimentos populares legalmente constituídos em associações -, bem como sindicatos e órgãos de classe. A presença desse tipo de liderança, de acordo com os relatos das entrevistas, contribui para a organização dos trabalhos no Conselho e para o processo decisório, pois os líderes norteiam os demais em determinadas situações. Por outro lado, não foram verificados líderes vitalícios nos Conselhos de Mato Grosso e Mato Grosso do Sul, o que apresenta duas facetas. Na primeira delas, Silva (2005, p. 121), considera que "este tipo de liderança possui características negativas, podendo ser uma forma de reinventar o coronel, devido à falta de preparação de um sucessor local”.

Já a segunda apresenta a visão de que a experiência dos conselheiros vitalícios pode contribuir para a tomada de decisão do CES. Likert (1979) considera que no processo decisório o líder utiliza todos os seus conhecimentos disponíveis tanto para orientar o nível de alto escalão quanto o de baixo escalão - já abordados anteriormente no tocante à sua adequação ao ambiente dos CES - na discussão das metas e prioridades estabelecidas. Dessa forma, ao considerar que a experiência pode auxiliar no processo decisório do CES encontra-se, também, uma característica positiva para as lideranças vitalícias. Para o caso dos três Conselhos o que verificou-se tendência média para o indicador liderança. Dessa forma, é necessário destacar que a referida tendência apresenta cenário no qual o CES funciona sob um gestor de saúde independente, dado que a liderança do Conselho não consegue responder às necessidades de saúde da população, pois o gestor se mostra imparcial e alheio aos pleitos da instância participativa (não homologa suas deliberações).

Por fim, em relação ao indicador mobilização de recursos verificou-se novamente que nos três Conselhos a tendência média foi constatada. A motivação para essa tendência se justifica por haver contribuição periódica da União, Estado e Municípios, cujo acompanhamento da aplicação de recursos por parte de CES é realizado, mas sem controlar a utilização dos gastos. Cumpre-se salientar que o acompanhamento e controle dos gastos são termos distintos, pois o fato de somente acompanhar não inibe, por exemplo, a devolução de recursos não utilizados ocorrida em Goiás.

Ao relacionar a participação com o controle de gastos Rifkin (1990, p. 10) afirma que "la participacion supone..., atctividades organizadas para aumentar, em determinadas 
situaciones sociales, el control sobre los recursos y las instituciones de reglamentación por parte de grupos y movimientos de quienes hasta entonces se hallaban excluidos de dicho control". A abordagem da autora se mostra pertinente na medida em que considera o aumento da participação como importante fator para o controle aplicação de recursos. Para o caso da saúde a participação dos Conselhos poderia ocasionar maior controle dos gastos das Secretaria Estaduais de Saúde, mas não foi o que se constatou. Dessa forma os Conselhos parecem não conseguir operacionalizar o disposto na legislação - fiscalizar e controlar os gastos da saúde.

Fleury e Lobato (2009, p. 242) afirmam que a "democracia é conferida pela amplitude (e qualificação) da participação do processo deliberativo". O fragmento apresentado pode conferir ao contexto, ora abordado, sentido que exibe a fiscalização e o controle dos gastos - vistos como parte integrante dos aspectos que permeiam a democracia, cujo povo tem espaço para participar da condução do Estado - como elementos incrementados pela qualificação da amplitude de participação social do processo deliberativo do Conselho. Assim, considera-se a hipótese dos CES não possuírem a qualificação necessária, em termos de participação, para fazer com que o gestor da saúde atue no sentido de aplicar os recursos de acordo com aquilo que foi preconizado, por exemplo, no PES, ou seja, que promova a gestão em parceria com o Conselho no sentido de atender às necessidades da sociedade.

Destaca-se, ainda, em relação à fiscalização dos recursos, que os Conselhos de Mato Grosso e Mato Grosso do Sul apresentaram histórico em que Relatórios Anuais de Gestão foram reprovados. Logo, entende-se que inconsistências foram encontradas, inclusive com respeito a informações relativas ao repasse de determinados programas e ações não devidamente apresentados nas prestações de contas. Contudo, mesmo considerando o fato de relatórios serem reprovados vale destacar que os Conselhos não controlam os gastos dos gestores, pois as não conformidades dos aspectos legais, por exemplo, da LC 141/2012, por vezes, continuam a acontecer. Sendo assim, a relação de parceria mencionada anteriormente não se mostrou presente, fato que remota a tendência média do indicador liderança - gestor atua de forma independente. 


\subsection{Qualidade da Informação das Prestações de Contas das Secretarias Estaduais de Saúde}

A avaliação dos aspectos qualitativos da informação contábil, na perspectiva dos relatórios de prestação de contas da saúde, buscou descrever a qualidade da informação destes. Consoante a isso, vale ressaltar que este objetivo representa apenas parte da proposta geral da pesquisa, motivo pelo qual insere-se a tendência da amplitude de participação social como elemento que pode gerar maior qualidade nos relatórios de prestação de contas. É com esse cenário que procedeu-se à avaliação das prestações de contas das Secretarias Estaduais de Saúde de Goiás, Mato Grosso e Mato Grosso do Sul - referentes aos anos de 2011, 2012 e 2013.

A questão imbricada nesse panorama - conforme discussão do item 2.1.1 - faz referência à consideração do fato de que, à medida que o cidadão está mais vigilante às ações do gestor, este por sua vez vê-se na obrigação de prestar contas. Soma-se a isso o fato dos conselhos - representantes da sociedade civil e governo - possuírem atribuição legal ${ }^{35}$ para fiscalizar as ações do gestor. Por conseguinte, espera-se que maior amplitude de participação social possibilite maior qualidade aos relatórios. Logo, esta seção é parte integrante da busca pela confirmação ou não da expectativa mencionada. Ademais, como forma de apresentar as categorizações das dimensões e suas respectivas variáveis no tocante a qualidade da informação dos relatórios apresenta-se o quadro 22 com a síntese desse panorama.

\footnotetext{
${ }^{35}$ Resolução 453/2012 - Organização do Conselho - Terceira Diretriz: torna os Conselhos de Saúde uma instância privilegiada na proposição, discussão, acompanhamento, deliberação, avaliação e físcalização da implementação da Política de Saúde, inclusive nos seus aspectos econômicos e financeiros (grifo do autor).
} 


\begin{tabular}{|c|c|c|c|c|c|c|c|c|c|c|c|c|c|c|c|c|}
\hline \multicolumn{17}{|c|}{ Tendência das variáveis } \\
\hline Estado & Dimensão & Variárel & $1^{\circ} / 2011$ & $2^{0} / 2011$ & $3^{\circ} / 2011$ & $4^{0} / 2011$ & 2011 & $1^{\circ} / 2012$ & $2^{2} / 2012$ & $3^{\circ} / 2012$ & 2012 & $1^{0} / 2013$ & $2^{2} / 2013$ & $3^{\circ} / 2013$ & 2013 & 2011 a 2013 \\
\hline \multirow{11}{*}{ GOIÁS } & \multirow{2}{*}{ Relevância } & Variável (1) & Restrita & Restrita & Restrita & Restrita & Restrita & Restrita & Restrita & Restrita & Restrita & Restrita & Restrita & Restrita & Restrita & Restrita \\
\hline & & Variável (2) & Restrita & Restrita & Restrita & Restrita & Restrita & Restrita & Restrita & Restrita & Restrita & Média & Média & Média & Média & Restrita \\
\hline & \multirow{3}{*}{ Materialidade } & Variável (3) & Média & Média & Média & Média & Média & Média & Ampla & Ampla & Ampla & Ampla & Ampla & Ampla & Ampla & Ampla \\
\hline & & Variável (5) & Restrita & Restrita & Restrita & Restrita & Restrita & Restrita & Restrita & Restrita & Restrita & Restrita & Restrita & Restrita & Restrita & Restrita \\
\hline & & Variável (6) & Restrita & Restrita & Restrita & Restrita & Restrita & Baixa & Restrita & Restrita & Restrita & Média & Média & Média & Média & Restrita \\
\hline & \multirow{4}{*}{$\begin{array}{l}\text { Representação } \\
\text { Fidedigna }\end{array}$} & Variável (7) & Restrita & Restrita & Restrita & Restrita & Restrita & Restrita & Restrita & Restrita & Restrita & Restrita & Restrita & Restrita & Restrita & Restrita \\
\hline & & Variável (8) & Restrita & Restrita & Restrita & Restrita & Restrita & Restrita & Restrita & Restrita & Restrita & Restrita & Restrita & Restrita & Restrita & Restrita \\
\hline & & Variável (9) & Restrita & Restrita & Restrita & Restrita & Restrita & Restrita & Média & Média & Média & Média & Média & Média & Média & Média \\
\hline & & Variável(11) & Média & Média & Média & Média & Média & Média & Média & Média & Média & Média & Média & Média & Média & Média \\
\hline & \multirow{2}{*}{ Tempestividade } & Variável (12) & Restrita & Restrita & Restrita & Restrita & Restrita & Restrita & Restrita & Restrita & Restrita & Restrita & Restrita & Restrita & Restrita & Restrita \\
\hline & & Varíável (13) & Média & Média & Média & Média & Média & Média & Média & Média & Média & Média & Média & Média & Média & Média \\
\hline \multirow{12}{*}{ MATO GROSSO } & \multirow{2}{*}{ Relevância } & Variável (1) & Restrita & Restrita & Restrita & Restrita & Restrita & Restrita & Restrita & Restrita & Restrita & Restrita & Restrita & Restrita & Restrita & Restrita \\
\hline & & Variável (2) & Média & Média & Média & Média & Média & Média & Média & Média & Média & Média & Média & Média & Média & Média \\
\hline & \multirow{4}{*}{ Materialidade } & Variável (3) & Ampla & Ampla & Ampla & Ampla & Ampla & Ampla & Ampla & Ampla & Ampla & Ampla & Ampla & Ampla & Ampla & Ampla \\
\hline & & Variável (4) & Ampla & Ampla & Ampla & Ampla & Ampla & Ampla & Ampla & Ampla & Ampla & Ampla & Ampla & Ampla & Ampla & Ampla \\
\hline & & Variável (5) & Restrita & Restrita & Restrita & Restrita & Restrita & Restrita & Restrita & Restrita & Restrita & Restrita & Restrita & Restrita & $\begin{array}{l}\text { Restrita } \\
\end{array}$ & $\begin{array}{l}\text { Restrita } \\
\end{array}$ \\
\hline & & Variável (6) & Restrita & Restrita & Restrita & Restrita & Restrita & Restrita & Restrita & Restrita & Restrita & Restrita & Restrita & Restrita & Restrita & Restrita \\
\hline & \multirow{4}{*}{$\begin{array}{l}\text { Representação } \\
\text { Fidedigna }\end{array}$} & Variável (7) & Restrita & Restrita & Restrita & Restrita & Restrita & Restrita & Restrita & Restrita & Restrita & Restrita & Restrita & Restrita & $\begin{array}{l}\text { Restrita } \\
\end{array}$ & Restrita \\
\hline & & Variável (9) & Restrita & Restrita & Restrita & Restrita & Média & Restrita & Restrita & Restrita & Média & Restrita & Restrita & Restrita & Média & Restrita \\
\hline & & Variável (10) & Restrita & Restrita & Restrita & Restrita & Restrita & Restrita & Restrita & Restrita & Restrita & Restrita & Restrita & Restrita & Restrita & Restrita \\
\hline & & $\begin{array}{l}\text { Variável (11) } \\
\end{array}$ & Média & Média & Média & Média & Média & Média & Média & Média & Média & Média & Média & Média & Média & Média \\
\hline & \multirow{2}{*}{ Tempestividade } & $\begin{array}{l}\text { Varíável (12) } \\
\end{array}$ & $\begin{array}{l}\text { Restrita } \\
\end{array}$ & $\begin{array}{l}\text { Restrita } \\
\end{array}$ & $\begin{array}{l}\text { Restrita } \\
\end{array}$ & Restrita & Restrita & Restrita & Restrita & Restrita & Restrita & Restrita & Restrita & Restrita & Restrita & Restrita \\
\hline & & Varíável (13) & Restrita & Restrita & Média & Média & Média & Média & Média & Média & Média & Média & Média & Média & Média & Média \\
\hline \multirow{13}{*}{$\begin{array}{c}\text { MATO GROSSO DO } \\
\text { SUL }\end{array}$} & \multirow{2}{*}{ Relevância } & Variável (1) & Restrita & Restrita & Restrita & Restrita & Restrita & Restrita & Restrita & Restrita & Restrita & Restrita & Restrita & Restrita & Restrita & Restrita \\
\hline & & Variável (2) & Restrita & Média & Média & Média & Média & Ampla & Ampla & Média & Ampla & Média & Média & Média & Média & Média \\
\hline & \multirow{4}{*}{ Materialidade } & Variável (3) & Média & Média & Média & Ampla & Média & Ampla & Ampla & Ampla & Ampla & Ampla & Ampla & Ampla & Ampla & Ampla \\
\hline & & Variável (4) & Média & Média & Média & Média & Média & Ampla & Ampla & Ampla & Ampla & Ampla & Ampla & Ampla & Ampla & Ampla \\
\hline & & Varáável (5) & Restrita & Restrita & Restrita & Restrita & Restrita & Restrita & Média & Restrita & Restrita & Restrita & Restrita & Restrita & Restrita & Restrita \\
\hline & & Variável (6) & Média & Média & Média & Média & Média & Média & Média & Média & Média & Média & Média & Média & Média & Média \\
\hline & \multirow{5}{*}{$\begin{array}{l}\text { Representação } \\
\text { Fidedigna }\end{array}$} & Variável (7) & Restrita & Média & Média & Média & Média & Média & Média & Média & Média & Média & Média & Média & Média & Média \\
\hline & & Variável (8) & Restrita & Restrita & Restrita & Restrita & Restrita & Média & Média & Restrita & Média & Média & Média & Média & Média & Média \\
\hline & & Variável $(9)$ & Média & Média & Média & Média & Média & Ampla & Ampla & Ampla & Ampla & Ampla & Ampla & Ampla & Ampla & Ampla \\
\hline & & Variável (10) & Restrita & Restrita & Restrita & Ampla & Restrita & Ampla & Ampla & Ampla & Ampla & Ampla & Ampla & Ampla & Ampla & Ampla \\
\hline & & $\begin{array}{l}\text { Varíável (11) } \\
\end{array}$ & Média & Ampla & Ampla & Ampla & Ampla & Ampla & Ampla & Ampla & Ampla & Ampla & Ampla & Ampla & Ampla & Ampla \\
\hline & \multirow{2}{*}{ Tempestividade } & Varíável (12) & Restrita & Restrita & Restrita & Restrita & Restrita & Restrita & Restrita & Restrita & Restrita & Restrita & Restrita & Restrita & $\begin{array}{l}\text { Restrita } \\
\end{array}$ & $\begin{array}{l}\text { Restrita } \\
\end{array}$ \\
\hline & & Varíável (13) & Média & Média & Média & Média & Média & Restrita & Restrita & Restrita & Restrita & Restrita & Restrita & Restrita & Restritat & $\begin{array}{l}\text { Restrita } \\
\end{array}$ \\
\hline
\end{tabular}

Quadro 22 - Tendências das variáveis da qualidade dos relatórios de prestações de contas apresentados pelas SES do Centro Oeste.

Fonte: elaboração própria. 
4.2.1 Análise da Dimensão da Relevância nas prestações de contas das Secretarias Estaduais de Saúde

A tendência para a dimensão da relevância, nos relatórios das Secretaria de Saúde de Goiás, foi considera restrita. Esta categorização ocorreu em virtude de não haver nenhuma menção a recursos financeiros destinados para o ano seguinte, tampouco apresentados por programas e ações de saúde - resultado também verificado por Rezende (2013) na Secretaria Municipal de Saúde de Anápolis. A partir desse panorama já é possível considerar que o trabalho de planejamento dos conselheiros em relação aos objetivos e metas para a saúde fica prejudicado, pois não se tem meios proceder a esta análise com as informações constantes nos relatórios.

Outro ponto que prejudica a relevância da informação para o processo decisório do Conselho é a não confrontação dos resultados obtidos com as metas estabelecidas. Do ano de 2011 a 2012 o gestor não apresentou comparativos e só o fez em 2013, mas sem especificar as previsões orçamentárias. Isto evidencia uma melhora, mas não promove mudança no quadro de baixa qualidade dos relatórios, pelo menos no aspecto da relevância. Dessa forma, verifica-se que em se tratando de informações relevantes as prestações de contas ainda não estão adequadas ao exercício de controle social que o Conselho deve realizar com intuito de fiscalizar a gestão da saúde e promover o atendimento às necessidades da comunidade.

A dimensão da relevância para os relatórios da SES/MT apresentou tendência restrita no tocante a menção de recursos financeiros destinados ao exercício seguinte, bem como na SES/GO. Isso reitera a dificuldade dos conselheiros em avaliar e planejar as metas e objetivos. Em relação ao confronto de resultados obtidos com as metas verificou-se uma tendência média, fato que apresenta os resultados obtidos e os compara ao previsto. No entanto, não foram justificadas metas que não foram alcançadas. Dessa forma, é exigido dos conselheiros um trabalho maior no sentido de convocar os responsáveis por determinados programas e ações para fornecer maiores explicações, o que pode, em determinados casos, atravancar o processo de averiguação, dado que nem sempre se conseguem justificativas adequadas tempestivamente. Chama a atenção na análise dos relatórios de prestação de contas que a tendência da dimensão relevância é linear ao longo do período analisado (2011 a 2013), ou seja, a SES/MT não evoluiu na apresentação de informações que possibilitem aos conselheiros se planejarem melhor com o objetivo de propor melhorias e sugestões para a gestão da saúde, após suas avaliações.

Já no caso da SES/MS a tendência para esta dimensão foi considerada média. Por oportuno, cumpre-se destacar que a Secretaria de Saúde apresentou uma situação interessante 
em seus relatórios, no sentido de que não foram evidenciadas previsões de recursos para o ano seguinte - como no caso da SES/GO -, mas houve comparação posterior com a "previsão orçamentária" realizada anteriormente. Ocorre que apesar não terem sido abordadas metas e objetivos para o ano seguinte, fato que não permite o devido planejamento do CES e dos profissionais da saúde, foram realizados, no exercício corrente, confrontos entre o previsto e executado. Gonçalves et al. (2013, p. 32) encontraram resultado semelhante e o atribuiram a uma provável "falta de comprometimento por parte do gestor público, haja vista que os aspectos complementares como as metas e objetivos futuros deixam de ser evidenciados para em um momento posterior apresentá-los a partir dos resultados já obtidos”.

As informações relativas à programação de ações de saúde para o exercício seguinte podem auxiliar o conselheiro de saúde a não só entender como está sendo desenvolvido o planejamento da saúde, mas também propor melhorias a partir de intervenções e diálogo com os responsáveis pela da gestão da saúde pública. Dessa forma, esse tipo de informação se torna importante para a consecução do planejamento e, por consequência, do controle da gestão da saúde. De acordo com Gonçalves et al. (2011) a ausência de informações como essas compromete qualquer reivindicação ou planejamento por parte do Conselho, bem como de profissionais ligados a saúde, pois para diminuir ou aumentar determinado montante de recursos a ser aplicado é preciso verificar na prestação de contas a sua previsão. Ademais, o referido panorama não permite que tanto a sociedade quanto os conselheiros possam acompanhar as metas, objetivos e prioridades determinados pela Secretaria Estadual de Saúde em face da programação orçamentária do ano seguinte (GONÇALVES et al., 2013).

4.2.1.1 Análise da subdimensão Materialidade nas prestações de contas das Secretarias Estaduais de Saúde

A materialidade pode ser vista como requisito mínimo necessário para que a informação possa ser útil para o usuário da informação (GLAUTIER; UNDERDOWN, 2001). Logo, caso a informação seja útil pode-se dizer que a mesma passa a ser material (HENDRIKSEN; VAN BREDA, 2011). Para os relatórios de prestação de contas o que se considera em termo de utilidade da informação é se os recursos aplicados foram apresentados de acordo com programas e ações determinados para saúde, bem como discriminados por fonte recursos. Ao avaliar a materialidade para os relatórios de prestações de contas da SES/GO 
verificou-se uma tendência ampla para apresentação da aplicação de recursos por programas e ações, inclusive mencionando as fontes. Vale mencionar que houve evolução nos dois aspectos mencionados, pois a partir do segundo quadrimestre de 2012 os recursos aplicados foram apresentados com percentual de execução e valor aplicado no semestre, além de mencionar o acumulado. No caso da indicação das fontes de recursos o comportamento foi o mesmo. Apesar de não haver citação nos relatórios de prestação de contas relativa ao acatamento de sugestões de melhorias encaminhadas pelo CES, fato que não foi verificado em momento algum, a evolução ocorrida nesses dois aspectos anteriores apresenta um cenário cujo controle social das ações do gestor pode ser mais atuante, dado que é possível avaliar como os recursos estão sendo aplicados.

Como já abordado, a relação entre o CES e a Secretaria de Saúde, pelo menos nos relatórios de prestações de contas, não apresentou um cenário em que o Conselho participe das decisões do gestor da saúde. Nesse sentido, a tendência para esse aspecto é considerada restrita. Por outro lado, cumpre-se mencionar que também não foram apresentadas metas e objetivos para o ano seguinte, considerando o período de 2011 a 2012, fato que prejudica o planejamento dos conselheiros em relação à gestão da saúde em seus vários programas e ações. Contudo, houve uma melhora nesse quadro no ano de 2013, pelo fato das prestações de contas apresentarem metas relativas a indicadores como cobertura de pré-natal, cobertura vacinal da tríplice viral dentre outros. Nesses casos foram apresentadas a metas anuais de acordo com as diretrizes do PES, bem como seus níveis percentuais de atingimento de metas até o momento e o que se esperava para o ano seguinte. Já nesses casos é possível que a avaliação dos conselheiros em relação as metas e objetivos seja facilitada na medida em que as informações são apresentadas de maneira mais clara.

No que se refere aos relatórios da SES/MT a tendência da subdimensão materialidade foi considerada ampla para dois aspectos e restrita para os outros dois. A categorização para os primeiros dois aspectos se deve a evidenciação de recursos aplicados por programas e ações, inclusive apontando os montantes utilizados nos trimestres e o percentual de execução de acordo com valor total orçado. Além disso, as fontes de recursos também são identificadas. Fatores como esses auxiliam o trabalho dos conselheiros de saúde na medida em que fornecem condições destes avaliarem o planejamento da SES no sentido de atender às demandas da sociedade. Um exemplo é verificar que determinado programa só teve $20 \%$ de execução até o mês de agosto. Um fator como esse deve chamar a atenção dos conselheiros, pois 
a verba apresenta indícios de que não será executada como o previsto, em sua totalidade. Portanto, é dever do CES interpelar a SES para que se possa explicar e justificar o motivo pelo qual o programa não está sendo executado como deveria.

Ainda com relação a dimensão da materialidade - dois últimos aspectos - para os relatórios de prestação de contas da SES/MT vale destacar que em nenhum momento foram feitos apontamentos relativos a metas e objetivos para o ano seguinte, bem como não houve menção em momentos algum, por parte da secretaria, a sugestões de melhoria realizadas pelo CES e acatadas pelo gestor. Em contraponto à questão da aplicação de recursos por programas e ações, identificando-os por fontes, esses aspectos não colaboram para o cumprimento das atribuições dos conselheiros, pois prejudicam o devido acompanhamento da saúde com respeito ao planejamento para o ano seguinte, além de demonstrarem que a Secretaria não está atuando de maneira a estabelecer relação de parceria com o CES.

Os relatórios da SES/MS apresentaram evolução relativa à evidenciação da aplicação de recursos, inclusive indicando fontes, ao longo do intervalo de 2011 a 2013, chegando, assim, a uma tendência ampla em ambas. Diante disso, é possível considerar que os conselheiros de saúde possuem informações materiais para avaliar se ações do gestor da saúde estão alinhadas ao que foi previsto na Programação Anual da Saúde, inclusive em relação ao Plano Estadual de Saúde, bem como para verificar se os percentuais de recursos repassados pelos os entes federativos efetivamente estão sendo cumpridos. As referidas análises permitem que seja exercido controle social da saúde, pois na medida em que os conselheiros e sociedade são mais vigilantes, e as informações consideradas matérias são divulgadas é possível propor melhorias para a gestão da saúde. Além disso, citam-se, ainda, outras duas características importantes para que as informações sejam materiais nos relatórios de prestação de contas, no caso a participação do conselho no sentido apresentar sugestões de melhoria, em seus pareceres, para que sejam acatadas pelo gestor da saúde e a apresentação de metas e objetivos que a Secretaria de Saúde tem para conduzir a gestão da saúde no ano seguinte. Para as duas características apresentadas a tendência considerada foi restrita.

Para a primeira questão apresentada - sugestões de melhoria à SES - os relatórios de prestação de contas da Secretaria Estadual de Saúde de Mato Grosso do Sul apresentaram tendência restrita, o que indica o não atendimento das sugestões de melhoria propostas pelos conselheiros de saúde. Nesse casso, é possível supor que mesmo na hipótese dos conselheiros realizarem o controle social, este não parece ser efetivo, pelo menos para o quesito, ora abordado, 
pois o gestor não apresenta compromisso em atender e solucionar eventuais problemas elencados nos pareceres dos CES/MS. Além disso, é possível inferir que o panorama apresentado pode caracterizar a participação que a sociedade possui nas ações voltadas para à saúde (GONÇALVES et al., 2011).

Com respeito as metas e objetivos para o ano seguinte é possível afirmar que a SES/MS apresentou algumas, mas ainda sim de forma parcial, o que caracterizou tendência média. Este tipo de informação quando apresentada de forma parcial prejudica a avaliação dos conselheiros no que tange ao planejamento da saúde, pois inviabiliza, em determinados momentos, questionamentos e possíveis sugestões de melhoria. Indo mais além, é possível que a participação do conselheiro seja comprometida para esse quesito - avaliar se as metas e objetivos estão adequados às necessidades da sociedade em relação à saúde.

4.2.2 Análise da Dimensão da Representação Fidedigna nas prestações de contas das Secretarias Estaduais de Saúde

A avaliação da Dimensão da Representação Fidedigna envolve aspectos ligados à confiabilidade que os relatórios de prestação de contas transmitem aos conselheiros de saúde a partir da conversão das ações praticadas pelo gestor em números e informações presentes nestes relatórios. Portanto, importa saber se foram divulgadas prioridades para utilização dos recursos, se houve remanejamento dos mesmos, pois estas são informações que permitem ao usuário da informação (conselheiros e sociedade) avaliar a utilização dos recursos em virtude das necessidades mais prioritárias da sociedade, sobretudo se houver diminuição das receitas previstas para a saúde. Logo, neste último caso os remanejamentos devem ser realizados de acordo com a necessidade da saúde e não em virtude de uma mera indicação do gestor, pois é preciso que o Conselho aprove. Além disso, para se ter confiabilidade da informação é preciso também que os recursos previstos no PPA suportem a aplicação de recursos para as necessidades da saúde. Outro ponto é o apontamento, nas prestações de contas, dos aspectos que necessitam de melhoria, caracterizando dessa forma, a neutralidade do gestor acerca de sua gestão. Por fim, para que a informação dos relatórios de prestações de contas seja confiável é preciso que atenda à legislação aplicável em todos seus pontos. 
Em face dos aspectos elencados, a tendência da representação fidedigna nos relatórios de prestações de contas da Secretaria de Saúde de Goiás foi considerada restrita. A seguir são apresentados alguns dos fatores que motivaram essa categorização, quais sejam:

i) não há divulgação de pontos que necessitam de melhoria na gestão da saúde, apresentando, assim, maior parcialidade do gestor da saúde e, por consequência, menos confiabilidade da informação neste quesito - tendência restrita;

ii) Atendimento parcial das informações requeridas pela legislação vigente - média. As prestações de contas do CES/GO não apresentaram a agenda de saúde e suas respectivas prioridades, com exceção dos $2^{\circ}$ e $3^{\circ}$ quadrimestre de 2012, nos quais são apresentados alguns indicadores e alguns eixos prioritários, mas de maneira superficial. De certa forma, isto corrobora o não estabelecimento de prioridades para a destinação de recursos (aspecto da dimensão da representação fidedigna), pois deixa de elencar o que efetivamente deve ser priorizado no atendimento às necessidades da comunidade. Para o Ministério da Saúde (2002, p. 7):

\footnotetext{
As agendas são compostas pelo conjunto de eixos prioritários de intervenção, justificados e detalhados em objetivos e indicadores. As Agendas de Saúde, ao serem consolidadas e adaptadas em cada esfera de governo, comporão um processo de responsabilização progressiva, tendo por base as orientações de governo, os fóruns de saúde e as referências epidemiológicas e institucionais de cada esfera, sempre com a homologação do respectivo conselho de saúde. O processo de construção das Agendas tem, assim, um percurso descendente.
}

Diante disso, considera-se fator necessário que os relatórios de prestações de contas apresentem mais elementos ligados à agenda de saúde, pois é partir desta que são construídos os Planos de Saúde e suas respectivas revisões anuais. Este é um exemplo que nem todas os aspectos elencados na legislação foram acatados pelas Secretarias de Saúde;

iii) não foram divulgados remanejamentos de recursos, fato que corrobora o não estabelecimento de prioridades - tendência restrita. É válido destacar que a não divulgação deste tipo de informação pode prejudicar a avaliação do conselheiro em relação ao atendimento das prioridades da alocação de recursos estabelecida pela SES (GONÇALVES et al., 2011). 
A tendência da dimensão da representação fidedigna para os relatórios de prestação de contas da SES/MT foi considerada restrita e suas principais motivações podem ser descritas a partir dos seguintes pontos:

i) não divulgação de pontos de prioridades para alocação de recursos nos relatórios, caracterizando, assim, que o gestor da saúde pode empregar recursos de forma aleatória, ou seja, sem utilizar parâmetros consistentes para avaliar prioridades mais relevantes Gonçalves et al. (2013) - tendência restrita;

ii) Com respeito às retificações orçamentárias verificou-se que só constavam os programas e ações os quais estavam sendo retirados recursos, portanto, sem mencionar a destinação dos mesmos. Dessa forma, os programas e ações envolvidos foram apresentados parcialmente. Logo, é possível dizer que a não divulgação deste tipo de informação pode prejudicar a avaliação do conselheiro em relação ao atendimento das prioridades da alocação de recursos estabelecida pela SES (GONÇALVES et al., 2011) - tendência média;

iii) não houve divulgação dos montantes alocados na saúde em consonância com a vigência do PPA, fato que dificulta a capacidade dos conselheiros em prever determinados cenários no sentido de tomar medidas preventivas Gonçalves et al. (2013) - tendência restrita;

iv) os relatórios não apresentam pontos que necessitam melhorias relativos a gestão da saúde, o que levanta indícios da parcialidade do gestor da saúde, dado que o mesmo pode tentar demonstrar somente aquilo que lhe é favorável - tendência restrita.

Já para o Estado de Mato Grosso do Sul o resultado apresentou uma tendência média. A motivação para esta categorização se deu em virtude das informações contidas nos relatórios de prestações de contas da SES/MS possuírem nível de confiabilidade médio e, por conta disso, poderem contribuir para o exercício do controle social das ações do Estado de Mato Grosso do Sul. Nesse sentido, apresentam-se alguns fatores que motivaram a referida categorização: 
i) evolução com respeito à divulgação de pontos de melhoria na gestão da saúde passando de restrita $\left(1^{\circ}, 2^{\circ}\right.$ e $3^{\circ}$ trimestre/2011) para ampla ( $4^{\circ}$ trimestre de 2011 ao $3^{\text {o }}$ quadrimestre de 2013), apresentando, assim, maior neutralidade do gestor da saúde e, por consequência, mais confiabilidade neste quesito;

ii) Atendimento a boa parte da evidenciação de informações requeridas pela legislação vigente - tendência média;

iii) divulgação de remanejamentos com a destinação e partes envolvidas não chegou a ocorrer, pois somente foram mencionados remanejamentos em alguns relatórios. No que diz respeito a esse aspecto a análise do intervalo de 2011 a 2013, de forma geral, foi considerada média, justamente pelo fato da destinação dos recursos não ser evidenciada. Novamente destaca-se a mesma questão mencionada para esse quesito nos relatórios da SES/MT - a não divulgação desse tipo de informação pode prejudicar a avaliação do conselheiro em relação ao atendimento das prioridades da alocação de recursos estabelecidas pela SES (GONÇALVES et al., 2011) ;

iv) houve evolução com respeito à divulgação dos montantes alocados na saúde em consonância com a vigência do PPA. De acordo com Gonçalves et al. (2013, p. 33) a:

[...] a não divulgação dessa informação implica a limitação da sociedade de tomar conhecimento dos montantes destinados à Saúde durante a vigência do PPA, além de prejudicar a atuação dos conselheiros por reduzir o alcance da visão global acerca da disposição de recursos financeiros nesse período, impedindo, assim, a adoção de medidas preventivas, dificultando o controle e análise da execução das políticas de saúde e a destinação dos recursos.

Sob este prisma, é possível visualizar que há uma condição um pouco mais favorável para que o controle social seja exercido, sobretudo na hipótese de os conselheiros e sociedade estarem mais vigilantes para avaliar as informações disponibilizadas nas prestações de contas. 
4.2.3 Análise da Dimensão da Tempestividade nas prestações de contas das Secretarias Estaduais de Saúde

A avaliação da dimensão da tempestividade nos relatórios de prestação de contas está focada em dois aspectos. O primeiro deles diz respeito a menção da data em que será disponibilizado o próximo relatório de prestação de contas. Já o segundo se refere a data de entrega dos relatórios de prestações de contas ao CES, por parte da Secretaria de Saúde. Os dois aspectos permitem identificar se as informações sobre a gestão da saúde são consideradas relevantes, pois caso estejam disponíveis oportunamente, de forma a subsidiar o processo decisório no Conselho, podem ser consideradas de tal maneira.

Ao analisar informações relativas à disponibilização do próximo relatório de prestação de contas a serem encaminhados ao CES/GO constatou-se que a Secretaria de Saúde não evidenciou em momento algum este aspecto - apresentando, assim, tendência restrita. Esse tipo de ocorrência pode prejudicar o planejamento das atividades dos conselheiros na medida em que determinadas decisões precisam estar alinhadas com informações oportunas/tempestivas. Gonçalves et al. (2013) corrobora este pensamento ao afirmar que uma tendência restrita demonstra que o CES fica impossibilitado de planejar um calendário de atividades relativo ao uso da informação, pois o fato desta chegar de forma tardia pode prejudicar a eficácia do controle social.

Por outro lado, vale lembrar que disponibilização dos relatórios de prestação de contas, dentro do prazo legal, para o CES também instrumentaliza o processo decisório dos conselheiros. Para esse aspecto a tendência foi considerada média pelo fato de ser apresentado nos relatórios o mês em que foram disponibilizados pela Secretaria de Saúde ao Conselho. Todavia, é valido destacar que de todos os relatórios analisados somente o do $1^{\circ}$ Quadrimestre de 2012 foi entregue de acordo com o prazo legal (maio/2012) - Lei Complementar 141/2012. Esta verificação coaduna a situação encontrada no aspecto anterior - disponibilização do próximo relatório -, pois reforça a ideia de que decisões acerca da gestão da saúde podem não ser tomadas por conta da chegada tardia de determinadas informações, ou seja, da perda de sua relevância.

No caso do SES/MT a tendência da dimensão da tempestividade foi restrita para a apresentação das datas em que o próximo relatório de contas seria disponibilizado, e média para evidenciação das datas em que foram encaminhados pela SES ao Conselho. Novamente foi 
verificada a questão da impossibilidade dos conselheiros realizarem uma agenda de atividades. Em relação a data de encaminhamento dos relatórios ao Conselho houve uma evolução a partir do $3^{\circ}$ trimestre de 2011 no tocante a sua evidenciação, passando de restrita para média informando o mês em que foram entregues, sem especificar o dia. Todavia, em alguns quadrimestres ficou claro que o relatório foi enviado fora do prazo estabelecido pela legislação, fato que, como dito anteriormente, pode acarretar na perda da relevância da informação para os conselheiros.

A tendência para a SES/MS, em relação aos aspectos apresentados, foi considerada restrita. Isto indica que a Secretaria de Saúde, pelo menos para o período analisado, com respeito aos aspectos abordados, não tem subsidiado o processo decisório do Conselho de forma adequada. Como justificativa é possível citar dois aspectos: i) não há menção a data em que próximo relatório será disponibilizado; e ii) descumprimento do prazo legal de entrega dos relatórios e a disponibilização das datas de entrega. Em relação ao primeiro aspecto avalia-se, novamente, que existe impossibilidade de se planejar o calendário de atividades citado por Gonçalves et al. (2013). Em relação ao segundo aspecto tem-se o fato de que a informação contida nos relatórios pode perder a capacidade de fornecer meios para que os conselheiros de saúde possam intervir ou propor melhorias, de forma tempestiva, para determinados programas ou ações da saúde. A provável consequência disso é o não atendimento de determinadas demandas da comunidade.

O oficio CES/MS 255/2012 apresenta informação de que os relatórios do $1^{\circ}, 2^{\circ}$ e $3^{\circ}$ quadrimestres do mesmo ano não foram encaminhados dentro do prazo requerido na legislação. Este exemplo explicita que a informação pode ter perdido o seu caráter de relevância dado que não estava disponível em momento hábil para que o Conselho pudesse deliberar. Apenas nos relatórios dos últimos três trimestres de 2011 foram apresentadas, na primeira página, o mês em que os mesmos foram produzidos pela Secretaria de Saúde e encaminhados ao Conselho. Todavia, os três foram entregues fora do prazo estabelecido em legislação, apresentando, assim, a mesma situação questionável quanto a sua relevância para os conselheiros de saúde. 
4.2.4 Resultados gerais da avaliação da qualidade da informação das prestações de contas das Secretarias Estaduais de Saúde

De forma complementar à apresentação do quadro 22 optou-se por apresentar as tendências das categorias teóricas restrita, baixa, média e ampla na forma gráfica para os três Estados estudados. A justificativa para a referida escolha se motiva na apresentação justamente da tendência exposta ao longo do intervalo pesquisado (2011 a 2013) - o que adensa a análise do cenário encontrado. Primeiro são apresentadas as tendências para o Estado de Goiás - gráfico 02.

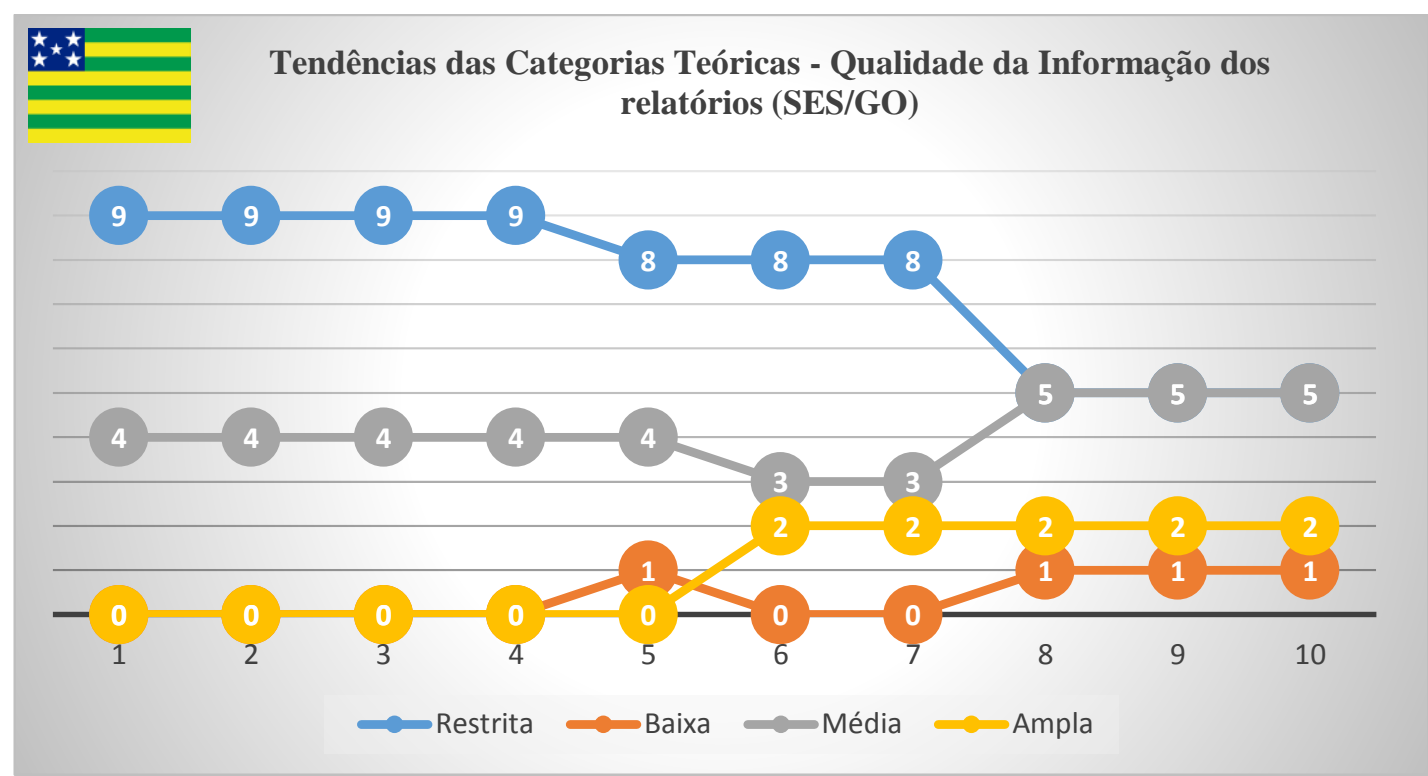

Gráfico 2 - Tendência das categorias teóricas - qualidade da informação dos relatórios ${ }^{36}$ (SES/GO) Fonte: elaboração própria.

O gráfico permite considerar que após o ano de 2011 o número de variáveis restritas começou a diminuir e se converter em médias e amplas. As variáveis que motivaram essa ocorrência foram: "confronto dos resultados obtidos com as metas estabelecidas para área de saúde", "evidenciação da aplicação de recursos financeiros", especificação das fontes de recursos", "objetivos e metas para o ano seguinte", "previsão de recursos compreendidos no PPA para área de saúde”. Dessa forma, pode-se dizer que houve uma melhora na qualidade das

\footnotetext{
${ }^{36}$ Cada número da sequência apresentada ( 1 a 10$)$ equivale a um trimestre $\left(2011-1^{\circ}\right.$ ao $\left.4^{\circ}\right)$ ou quadrimestre $(2012$ a $2013-5^{\circ}$ ao $10^{\circ}$ ).
} 
prestações de contas da SES/GO, mas não de maneira significativa, pois a quantidade de variáveis restritas chegou a 57\% do total de variáveis analisadas. A preponderância desse tipo de variável deixa clara a necessidade de melhoria dos relatórios no sentido de prover informações relevantes, materiais, confiáveis e tempestivas para os conselheiros cumprirem suas atribuições.

Das dimensões analisadas a que apresentou melhor qualidade foi a relevância pelo fato de possuir as únicas duas variáveis com tendência ampla - "evidenciação da aplicação de recursos financeiros", "especificação das fontes de recursos", as duas apresentadas no gráfico 01. O fato de terem sido verificadas apenas duas variáveis com tendência ampla também chama atenção para a necessidade de mudanças estruturais nos relatórios. Em relação à dimensão com pior qualidade pode-se citar a tempestividade em virtude da entrega das prestações fora do prazo, ocasionando, eventualmente, a perda de relevância e, por fim, a não disponibilização da data do próximo relatório - fato que prejudica o estabelecimento de um cronograma de trabalho. $\mathrm{O}$ gráfico 03 apresenta outra perspectiva - variáveis por ano.

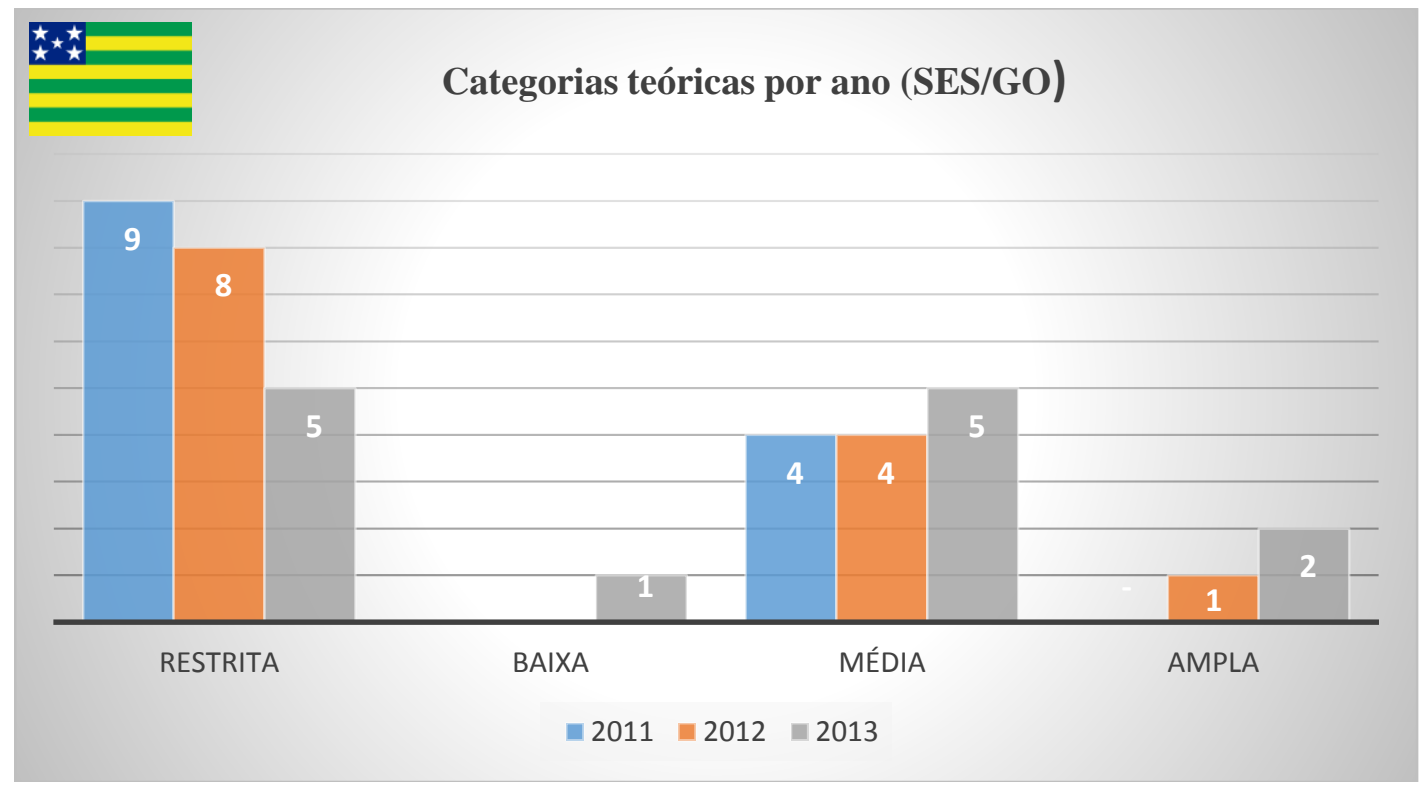

Gráfico 3 - Tendência das categorias teóricas da qualidade dos relatórios por ano (SES/GO). Fonte: elaboração própria.

O referido gráfico permite perceber claramente que a variável restrita é preponderante nos relatórios de prestações de contas da SES/GO. Ao considerar as variáveis com tendência média é possível visualizar uma tímida melhora em relação aos anos anteriores. Entretanto, essa variável chegou ao ano de 2013 com 40\% do total de tendências deste ano, 
diferentemente dos anos anteriores. Em face do exposto, o que se pode dizer é que os relatórios de prestações de contas da SES/GO possuem mais fragilidades do que pontos fortes (vide tendências amplas), o que pode prejudicar o exercício de controle social por parte do Conselho Estadual de saúde de Goiás.

Já com respeito à tendência das variáveis da qualidade da informação das prestações de contas da SES/MT o gráfico 04 apresenta um comportamento considerado regular, pois a maior parte das 13 variáveis analisadas teve comportamento inalterado ao longo do período analisado (2011-2013).

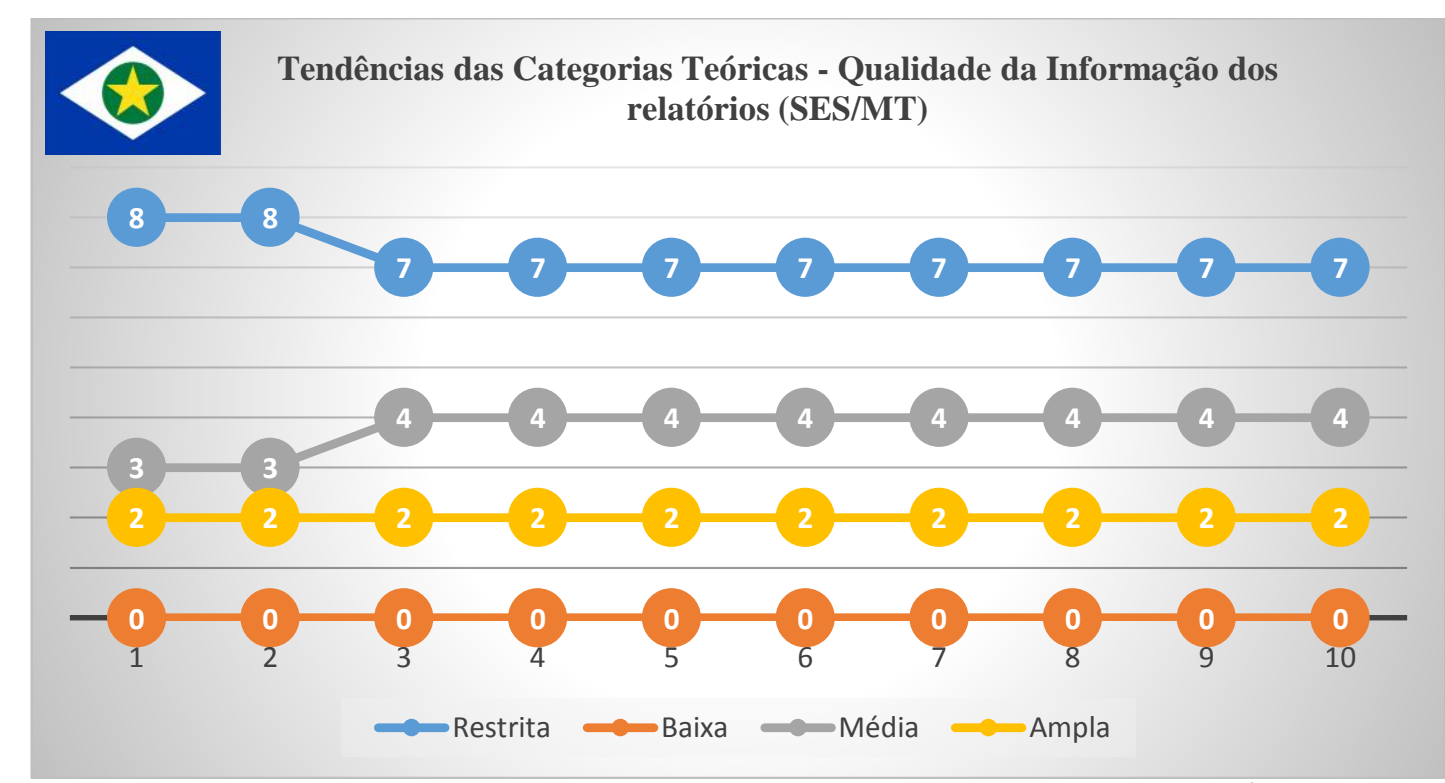

Gráfico 4 - Tendência das categorias teóricas - qualidade da informação dos relatórios ${ }^{37}$ (SES/MT). Fonte: elaboração própria.

No quesito variável com tendência ampla os relatórios de prestações de contas da SES/MT apresentam similaridade com os da SES/GO, justamente por estarem ligadas a "evidenciação da aplicação de recursos financeiros" e "especificação da fonte de recursos financeiros". O único fator que as diferencia é que em Mato Grosso as duas variáveis mencionadas tiveram tendência ampla desde o início. Pelo menos nos dois aspectos mencionados o exercício das atribuições dos conselheiros pode fluir de maneira a permitir a avaliação da aplicação de recursos de acordo com a programação orçamentária prevista, bem como o atendimento aos percentuais de aporte de recursos presentes na EC 29/2000 -

\footnotetext{
${ }^{37}$ Cada número da sequência apresentada ( 1 a 10) equivale a um trimestre $\left(2011-1^{\circ}\right.$ ao $\left.4^{\circ}\right)$ ou quadrimestre (2012 a $2013-5^{\circ}$ ao $\left.10^{\circ}\right)$.
} 
responsável por regulamentar os percentuais a serem investidos por Estados e Municípios. Outro ponto que deve ser mencionado se refere à diminuição de uma variável restrita, a partir do $3^{\circ}$ trimestre de 2011, a qual passou a ser média - variável “disponibilização do relatório em análise". Nesse caso, foram informadas as datas de entrega dos relatórios. No entanto, cerca de cinco relatórios foram entregues fora do prazo. De maneira geral, o resultado das tendências das variáveis analisadas constatou que $55 \%$ se referem a variáveis consideradas restritas, motivo pelo qual se constatou a necessidade de evolução em vários aspectos. Ao avaliar a última informação e somá-la à questão da regularidade das tendências das variáveis é possível verificar indícios de que mudanças de cenário seriam um pouco mais difíceis para os relatórios da SES/MT. Ocorre que a tendência geral não apresenta características que sustentem a ideia de uma mudança abrupta no sentido de melhorar a qualidade da informação dos relatórios encaminhados ao CES/MT. O gráfico 05 apresenta tendência das variáveis por ano.

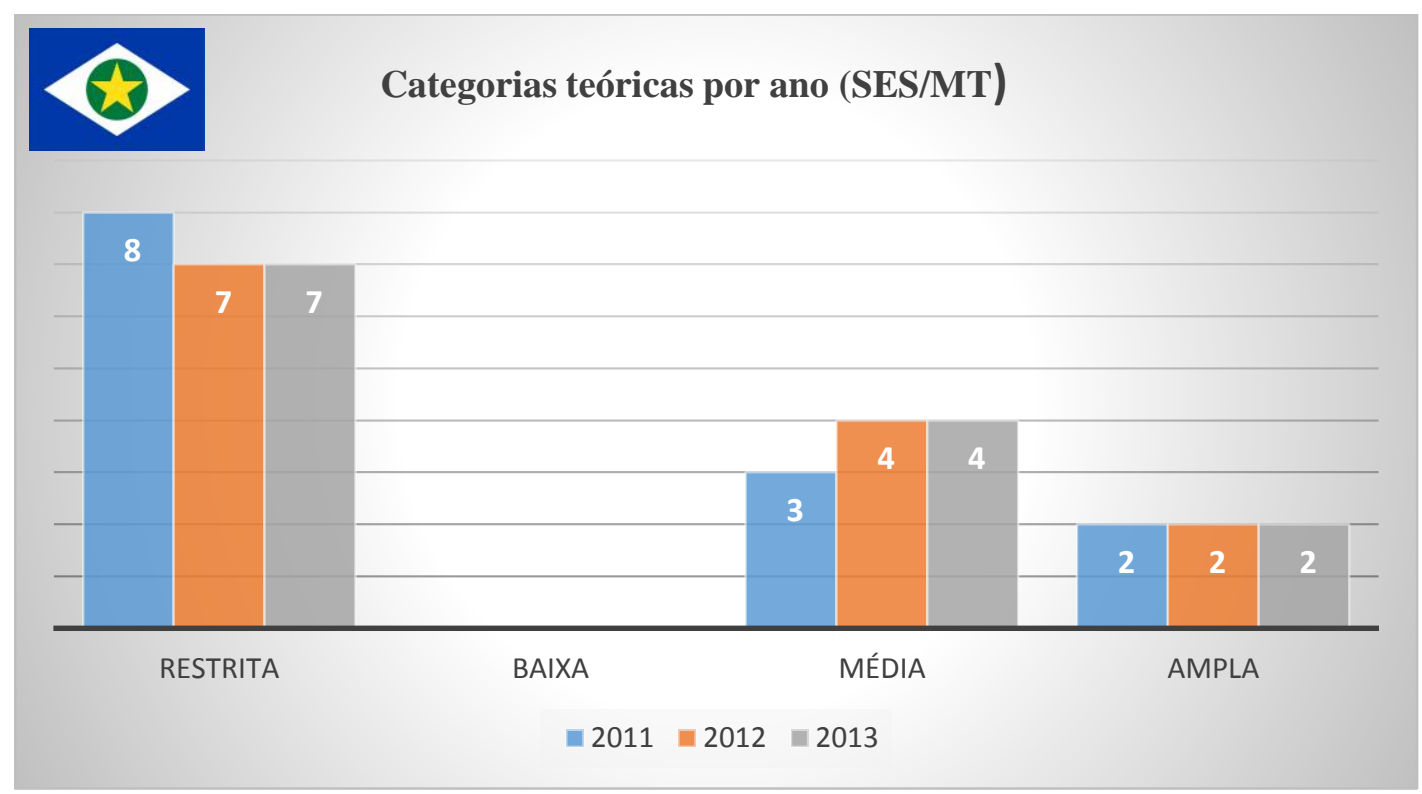

Gráfico 5 - Tendência das categorias teóricas da qualidade dos relatórios por ano (SES/MT). Fonte: elaboração própria.

O gráfico 05 deixa ainda mais clara a presença de variáveis com tendência restrita ao longo dos três anos analisados, caracterizando, portanto, comportamento homogêneo. No caso das variáveis médias e amplas o comportamento é similar, quanto à homogeneidade, mas ainda sim indica necessidade de melhorias, dado que o cenário apresentado parece estático e não apresenta tendência aumento no número de variáveis médias e amplas. Nesse sentido, é possível considerar que a efetividade do trabalho a ser realizado pelos conselheiros de saúde com base 
nos relatórios de prestações de contas pode, em determinados momentos, inviabilizar o atendimento às necessidades da comunidade. Já o gráfico 06 apresenta o comportamento das tendências das categorias teóricas pra os relatórios da SES/MS.

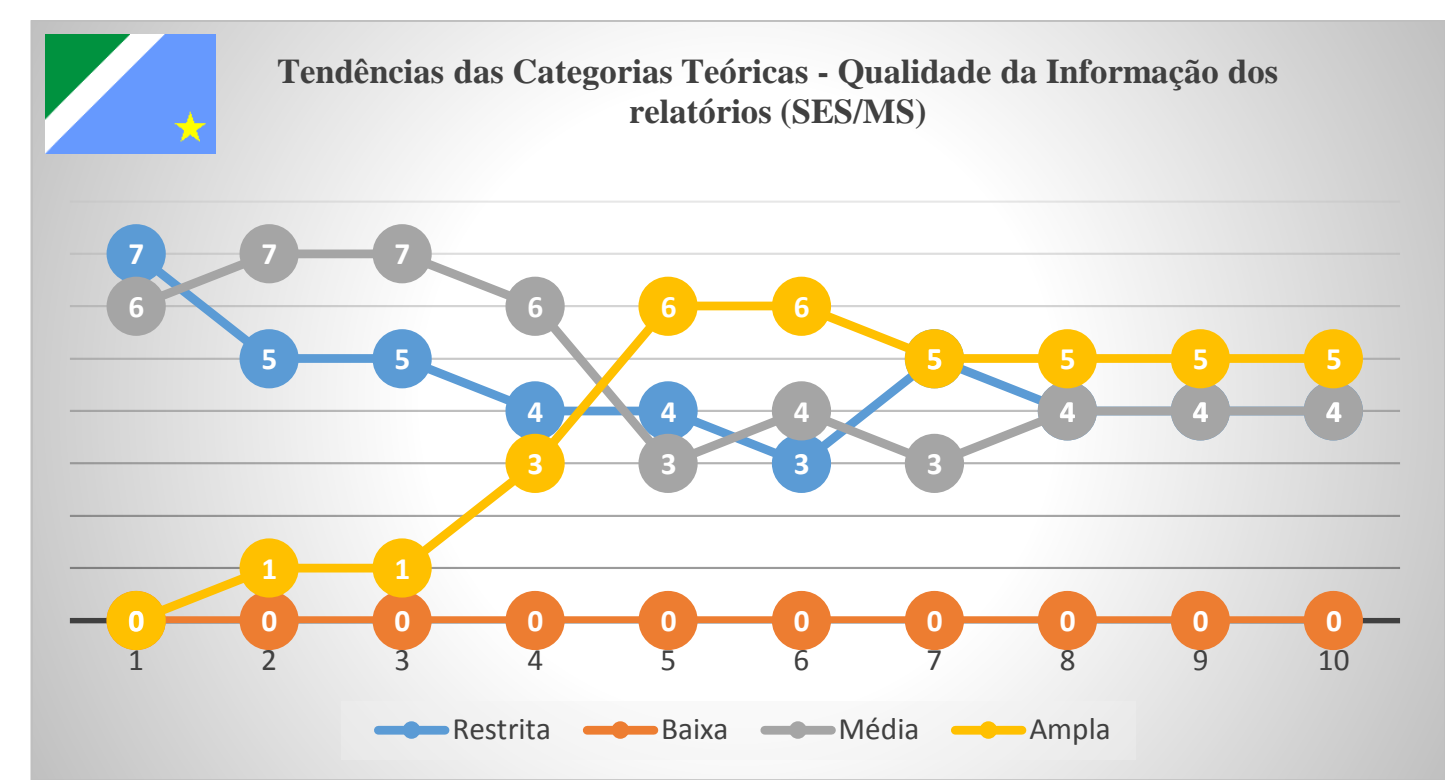

Gráfico 6 - Tendência das categorias teóricas - qualidade da informação dos relatórios ${ }^{38}$ (SES/MS). Fonte: elaboração própria.

O gráfico permite considerar que houve uma melhora de maneira geral na qualidade das prestações de contas. $\mathrm{O}$ aumento das ocorrências da categoria ampla está motivado, dentre outras, na variável divulgação das prioridades para a destinação de recursos financeiros. $\mathrm{O}$ principal ganho que a evolução desta variável proporciona é que ao evidenciar as prioridades estabelecidas abre-se espaço importante para que o Conselho, em acordo às suas competências legais, proponha sugestões e melhorias para o plano de ação do gestor da saúde (GONÇALVES et al., 2010). Igualmente, pode-se destacar a variável evidenciação da aplicação de recursos financeiros, pois também motivou o crescimento da categoria ampla. Ao apresentar na prestação de contas a aplicação de recursos por programas e ações permite-se que o conselheiro de saúde possa analisar se estes estão sendo destinados, por exemplo, àquilo que foi preconizado no Plano Estadual de Saúde.

Com respeito à categoria média cabe destacar que o seu comportamento poderia ter sido melhor caso a variável disponibilização do relatório em análise não tivesse apresentado

\footnotetext{
${ }^{38}$ Cada número da sequência apresentada ( 1 a 10$)$ equivale a um trimestre $\left(2011-1^{\circ}\right.$ ao $4^{\circ}$ ) ou quadrimestre $\left(2012\right.$ a $2013-5^{\circ}$ ao $\left.10^{\circ}\right)$.
} 
involução relativa a menção da data em que o relatório foi disponibilizado. Logo, entende-se que a SES/MS não disponibiliza tempestivamente os relatórios de prestação de contas, o que pode prejudicar o processo decisório em função da perda da relevância da informação. O percentual de ocorrência de variáveis com tendência média representou $41 \%$ do total analisado, fato que elucida a classificação geral da qualidade das prestações de contas da SES/MS com essa categoria teórica. Por fim, o gráfico 07 apresenta as categorias teóricas por ano.

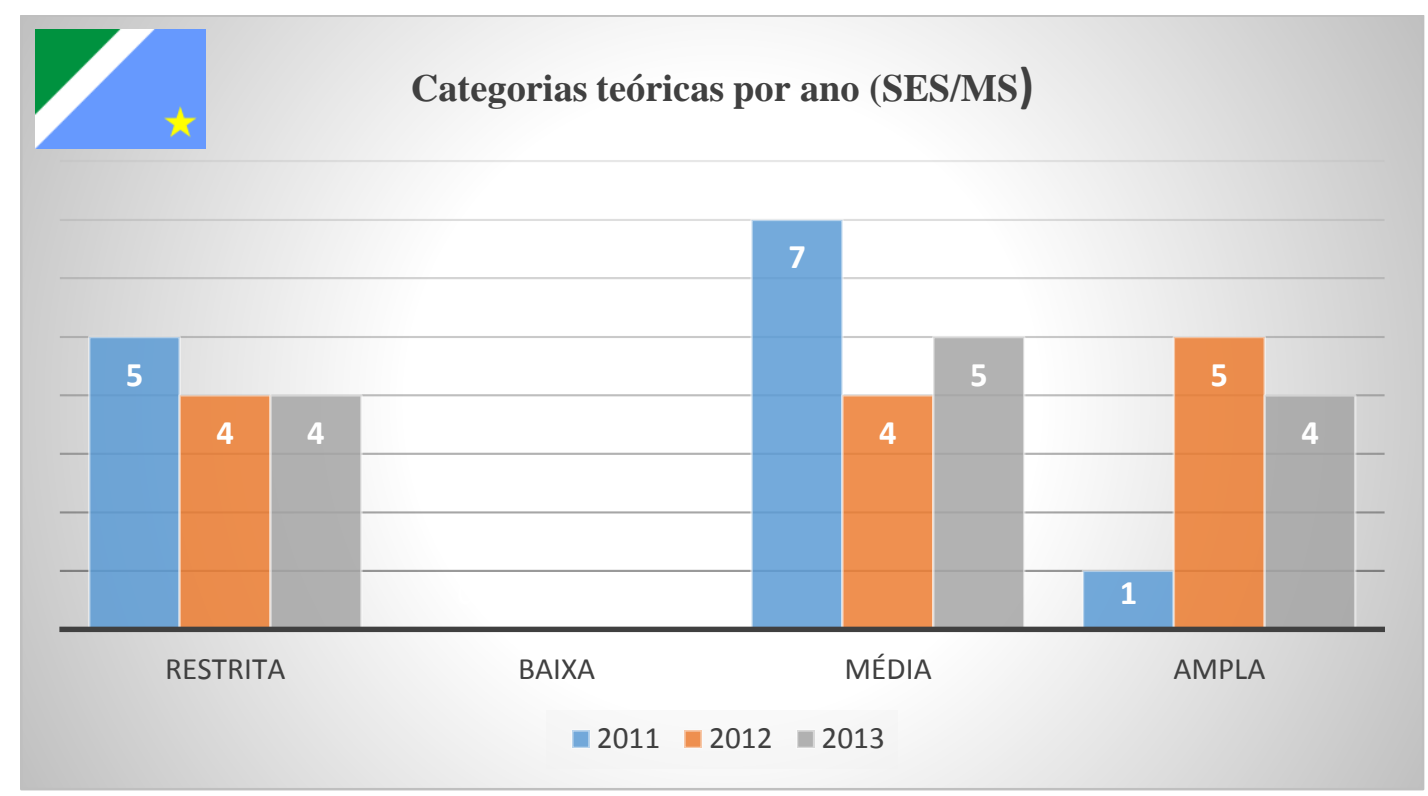

Gráfico 7 - Tendência das categorias teóricas da qualidade dos relatórios por ano (SES/MS).

Fonte: elaboração própria.

A partir do mesmo é possível perceber com maior clareza que existe diminuição na heterogeneidade das categorias apresentas de 2011 a 2013. Por outro lado, a regularidade positiva das categorias médias e amplas em 2012 e 2013 não permite inferir que qualidade da informação dos relatórios evoluiu sobremaneira, mas apresenta um cenário melhor e mais propício ao controle das ações do gestor da saúde do que o apresentado em 2011. Vale lembrar também que o panorama apresentado é melhor do que o apresentado em Goiás e Mato Grosso. O gráfico 08 exibe a síntese da qualidade dos relatórios de prestação de contas das Secretarias Estaduais de Saúde do Centro Oeste. 


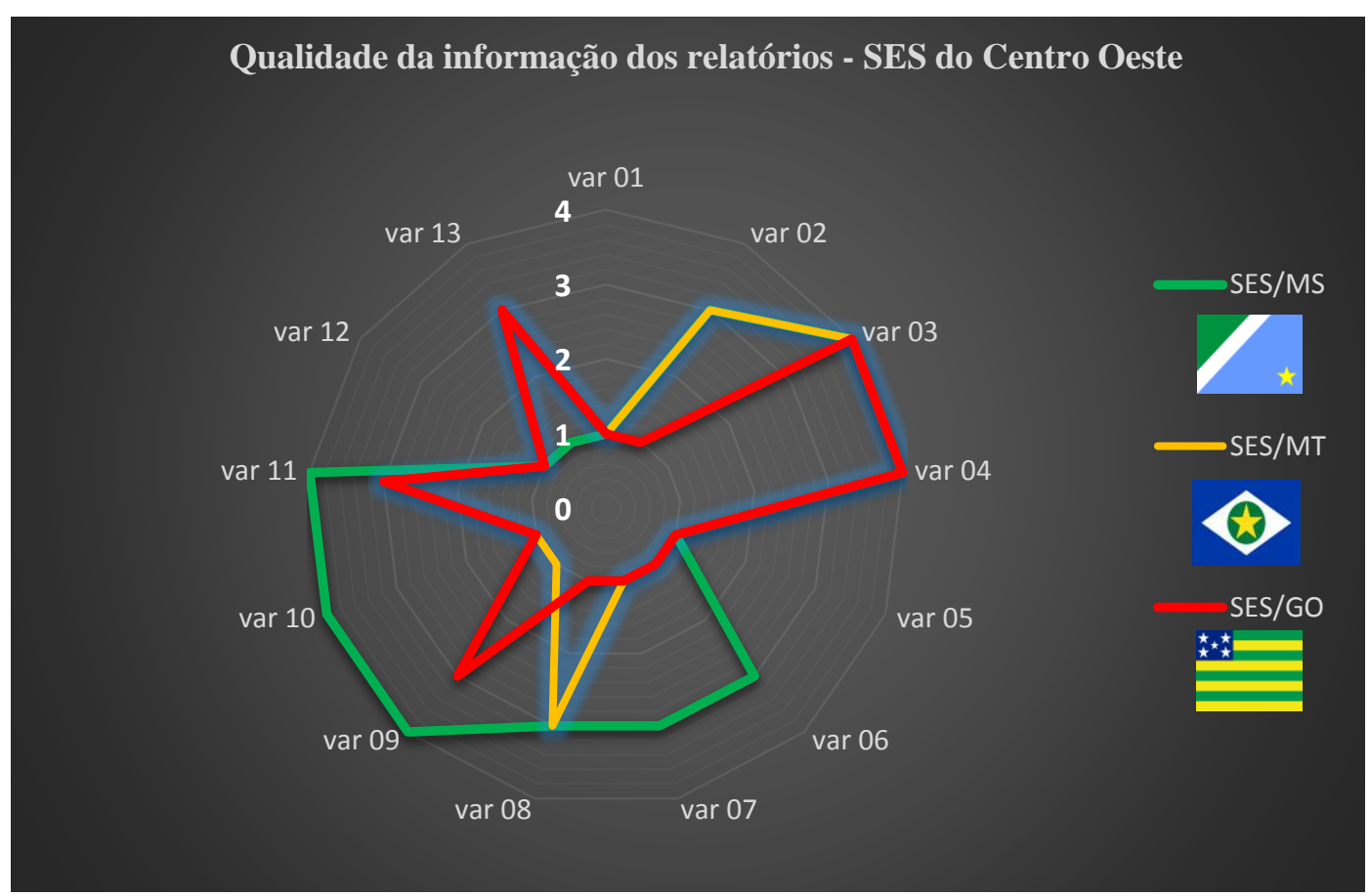

Gráfico 8 - Diagrama da qualidade da informação das SES do Centro Oeste.

Fonte: elaboração própria.

Legenda

Variável (1) - Recursos previstos na proposta/lei orçamentária

Legenda

Variável (2) - Confronto dos resultados com as metas estabelecidas para área de saúde

1 - Restrita

Variável (3) - Evidenciação da aplicação dos recursos financeiros

2 - Baixa

Variável (4) - Especificação da fonte dos recursos financeiros

3 - Média

Variável (5) - Participação do Conselho nas decisões da Secretaria de Saúde

4 - Ampla

Variável (6) - Objetivos e Metas para o exercício subsequente?

Variável (7) - Divulgação das prioridades para destinação dos recursos financeiros

Variável (8) - Evidenciação das retificações orçamentárias

Variável (9) - Previsão de recursos para os exercícios compreendidos no PPA para a área da saúde

Variável (10) - Divulgação dos pontos que necessitam de melhorias

Variável (11) - Evidenciação do conteúdo legal

Variável (12) - Periodicidade de disponibilização dos relatórios

Variável (13) - Disponibilização do relatório em análise

O gráfico 08 exibe maior qualidade da informação dos relatórios da Secretaria Estadual de Saúde de Mato Grosso do Sul, sobretudo nas variáveis: 06 - objetivos e Metas para o exercício subsequente, 07 - divulgação das prioridades para destinação dos recursos financeiros, 09 - previsão de recursos para os exercícios compreendidos no PPA para a área da saúde, 10 - divulgação dos pontos que necessitam de melhorias e 11 - evidenciação do conteúdo legal. É possível destacar entre as variáveis mencionadas o fato da SES/MS fornecer mais meios para que os conselheiros de saúde possam avaliar a gestão da saúde no Estado, pois ao estabelecer metas para o ano seguinte possibilita melhor planejamento para o CES/MS. Da 
mesma forma citam-se a divulgação de recursos compreendidos no PPA, bem como o estabelecimento e divulgação de prioridades para a saúde. Além disso, são mencionados nos relatórios pontos que precisam ser melhorados, indicando, portanto, indícios de que o gestor procura avaliar, em determinados momentos, o que está sendo realizado em termos de prestação de serviços de saúde.

As SES/GO e SES/MT como é possível ver no gráfico 08 apresentaram comportamento similar - de qualidade restrita. Nesse caso, consideravelmente inferior ao cenário apresentado em Mato Grosso do Sul. Os pontos positivos de destaque para as duas secretarias estão ligados às variáveis 03 - evidenciação da aplicação dos recursos financeiros, var 04 - especificação da fonte dos recursos financeiros. Vale destacar que as mesmas também apresentaram tendência ampla para a SES/MS. Para os Conselhos e sociedade é importante saber como os recursos são aplicados e qual é a sua origem, até para que se possa fiscalizar e propor, quando necessário, melhorias e adequações ao gestor da saúde.

\subsection{Amplitude de Participação Social da Comunidade e a Qualidade das Prestações de Contas das Secretarias de Saúde}

Os quadros 24,25 e 26 apresentam o resumo das categorizações das dimensões integrantes dos dois instrumentos de pesquisa utilizados neste trabalho. A sua função é avaliar se uma maior amplitude de participação social possibilita maior qualidade para os relatórios de prestações de contas emitidos pelas Secretarias de saúde e encaminhados aos Conselhos de Saúde. Por oportuno, salienta-se, em relação aos relatórios de prestações de contas, a existência dos pacotes de informação sejam eles obrigatórios, decorrentes dos obrigatórios ou voluntários - aspectos mencionados no item 3.2.4.

4.3.1 Amplitude da participação social do CES/GO e a Qualidade da Informação das Prestações de Contas da SES/GO

A apresentação do quadro $23, \operatorname{logo}$ abaixo, permite identificar claramente que a qualidade da informação dos relatórios de prestações de contas da SES/GO só obteve tendência médialampla nas variáveis de divulgação obrigatória. Isto significa dizer que só houve qualidade em aspectos pontuais pelo fato da legislação exigir a divulgação desse tipo de 
informação. Como forma de exemplificar o foco na divulgação de variáveis obrigatórias verificou-se que $41 \%$ do total de variáveis foram classificadas com tendência médialampla (33\% médias/8\% amplas), ao passo que o percentual de variáveis obrigatórias, antes de qualquer classificação, dentro do instrumento de evidenciação totalizou 38\%. Ou seja, das 13 variáveis que compõem o instrumento de evidenciação (100\%), cinco consideradas obrigatórias perfazem 38\% do total. Assim, ficou caracterizada a proximidade da qualidade da informação encontrada em relação ao percentual de variáveis obrigatórias, que só são divulgadas por imposição legal.

Além disso, cumpre-se salientar que nenhuma das variáveis de divulgação voluntária foi verificada, ou seja, todas exibiram tendência restrita. Dessa forma, ao analisar o resultado geral dos aspectos qualitativos da informação foi possível verificar que os relatórios de prestação de contas têm qualidade restrita - oito variáveis restritas de um total de 13, cerca de $61,50 \%$ dos aspectos analisados não foram divulgados. Nazário, Silva e Rover (2012) consideram que a qualidade da informação é pré-requisito essencial para que haja efetiva transferência de conhecimento e informações. Para o caso de Goiás a falta de qualidade da informação, portanto, não possibilita a efetiva transferência de informações e conhecimento acerca da gestão da saúde pública no Estado. 
Estado de Goiás

Amplitude de Participação Social

Implantação e departame
- Criado pelo decreto 3887/1992;
- Criação de Comis sões transitórias;

- Crião de GTs;

- Abertura por parte das comissões no sentido de agregar novos atores;

- Apoio técnico às comissões.

Avaliação das necessidades - Categorias teóricas intermediárias

- Avaliação das necessidades por diferentes meios;

- Plano Anual de Trabalho é discutido nas plenárias;

- Conselho pauta discussões em conferências e na elaboração do Plano de Saúde.

Secretaria Executiva estabelece hierarquia de prioridades para o encaminhamento das discussões sobre as necessidades.

\begin{tabular}{|c|c|c|}
\hline Liderança - Categorias teóricas intermediárias & \multicolumn{2}{|c|}{ Tendência } \\
\hline $\begin{array}{l}\text { - Liderança exercida pelos movimentos populares; } \\
\text { - Líderes natos; } \\
\text { - Deliberações não homologadas pelo governo do Estado; } \\
\text { - Decisões que buscam benefícios para a comunidade, mas sem efetividade; } \\
\text { - Conselheiros bem articulados. }\end{array}$ & \multicolumn{2}{|c|}{ Média } \\
\hline Mobilização de recursos - Categorias teóricas intermediárias & \multicolumn{2}{|c|}{ Tendência } \\
\hline $\begin{array}{l}\text { - O Governo Federal faz repasses periódicos; } \\
\text { - Estado repassa } 12 \% \text { do seu orçaemento; } \\
\text { - Gestor estadual apenas apresenta contas ao CES; } \\
\text { - A população acompanha a aplicação de recursos. }\end{array}$ & \multicolumn{2}{|c|}{ Média } \\
\hline Variáveis da Qualidade da Informação & Pacote & Tendência \\
\hline Variável (1) - Recursos pres vistos na proposta/lei orçamentária & Vo. & Restrita \\
\hline Variável (2) - Confronto dos resultados com as metas estabelecidas para área de saúde & Dob. & Restrita \\
\hline Variável (3) - Evidenciação da aplicação dos recursos financeiros & Ob. & Ampla \\
\hline Variável (4) - Especificação da fonte dos recursos financeiros & Ob. & Ampla \\
\hline Variável (5) - Participação do Conselho nas decisões da Secretaria de Saúde & Vo. & Restrita \\
\hline Variável (6) - Objetivos e Metas para o exercício subsequente? & Vo. & Res trita \\
\hline Variável (7) - Divulgação das prioridades para destinação dos recursos financeiros & Vo. & Restrita \\
\hline Variável (8) - Evidenciação das retificações orçamentárias & Dob. & Restrita \\
\hline Variável (9) - Previsão de recursos para os exercícios compreendidos no PPA para a área da saúde & Ob. & Média \\
\hline Variável (10) - Divulgação dos pontos que necessitam de melhorias & Vo. & Restrita \\
\hline Variável (11) - Evidenciação do conteúdo legal & Ob. & Média \\
\hline Variável (12) - Periodicidade de dis ponibilização dos relatórios & Vo. & Restrita \\
\hline Variável (13) - Dis ponibilização do relatório em análise & Ob. & Média \\
\hline
\end{tabular}

Quadro 23- Análise do resultado das tendências de amplitude de participação social e qualidade da informação em Goiás

Fonte: elaborado pelo autor.

Legenda

Ob. - Divulgação obrigatória em virtude de legislação.

Dob. - Divulgação decorrente da obrigatoriedade contida em legislação (periférica).

Vo. - Divulgação voluntária por parte do gestor.

No que se refere aos resultados das tendências de amplitude de participação social e da qualidade da informação das prestações de contas para o Estado de Goiás considerou-se que a participação restrita/média do CES não promoveu maior qualidade para os relatórios. Sob essa linha, destaca-se que não houve divulgação do conjunto de informações voluntárias, fator o qual esperava-se que promovesse uma participação mais ativa e qualificada por parte do CES, em virtude de demonstrar, em tese, atuação mais neutra e parceira por parte do gestor. 
Com efeito, a tendência da participação social restritalmédia em face da qualidade da informação restrita apresentou um quadro no qual a participação, em princípio, não possibilitou o incremento da qualidade da informação. Glautier e Underdown (2001) consideram que os principais aspectos qualitativos da informação necessários para que os usuários possam compreender as informações contidas nos relatórios e, por consequência, tomarem a melhores decisões possíveis, são a materialidade, a relevância e a confiabilidade. Sob essa ótica, verificase que a tendência restrita da qualidade da informação apresenta uma baixa qualidade dos relatórios no que tange às dimensões mencionadas.

O gráfico 09 é responsável por apresentar os indicadores de amplitude de participação social do CES em face das variáveis de qualidade da informação dos relatórios da SES. A partir deste e do quadro 23 são discutidos, de forma pontual, indicadores, categorias teóricas intermediárias da amplitude de participação sociale variáveis da qualidade da informação, todos pertencentes aos dois instrumentos de pesquisa utilizados neste trabalho.

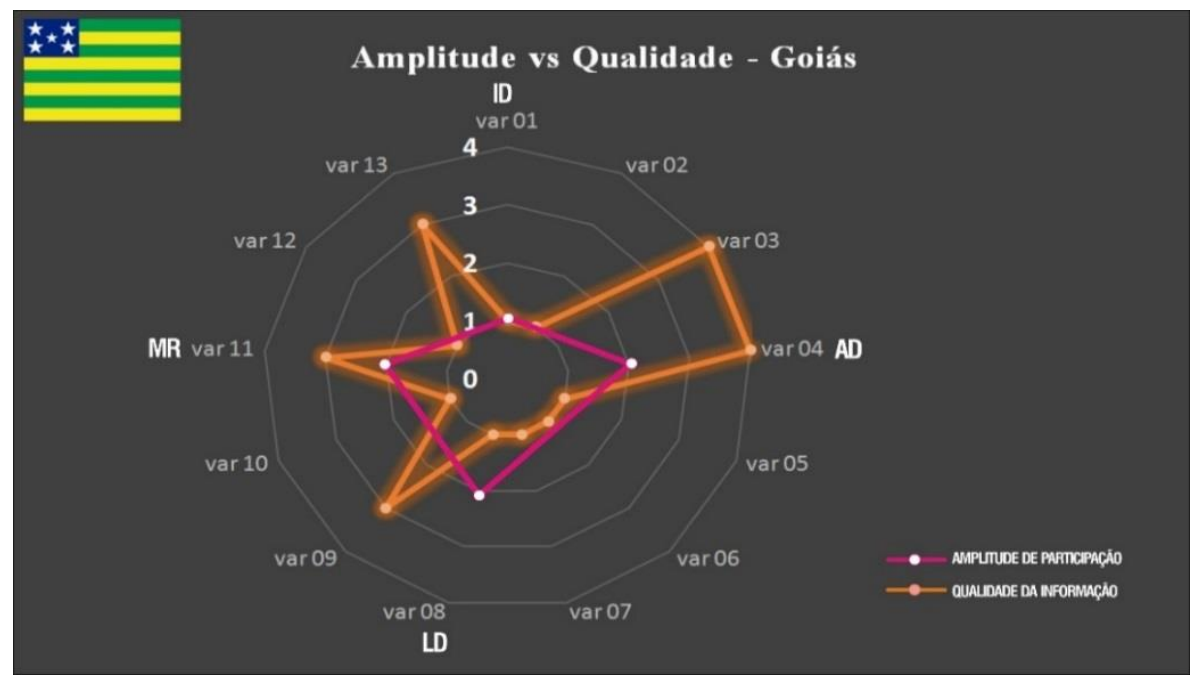

GRÁFICO 9 - Amplitude de participação social vs qualidade da informação - Goiás. Fonte: elaborado pelo autor.

No caso do indicador avaliação das necessidades, com tendência média, onde o “coordenador" representa o ponto de vista e avalia as necessidades da comunidade cumpre-se destacar uma das categorias teóricas intermediarias que fundamentam esta tendência "Secretaria Executiva estabelece hierarquia de prioridades para o encaminhamento das discussões sobre as necessidades" -, pois este aspecto figura como um ponto negativo que pode retirar a autonomia das comissões no ato de encaminhar e acompanhar as demandas apresentadas. Os Estados de Mato Grosso e Mato Grosso do Sul apresentam situação diferente 
na medida em que o CES/MS representa a comunidade e também avalia as suas necessidades - tendência aberta. Ocorre que nesse Estado, aparentemente, não há, por exemplo, a questão de uma Secretaria Executiva estabelecer prioridades de encaminhamento de discussões - fato que reduza atribuição das comissões. Por consequência, limitam o CES a obter somente o ponto de vista da avaliação das necessidades de saúde por meio de um "coordenador" e não da instancia participativa como um todo.

A avaliação das necessidades da saúde se analisada a partir de uma comparação com a var 09 (previsão de recursos para os exercícios compreendidos no PPA para a área da saúde - divulgação obrigatória) permite verificar se as necessidades poderão ser atendidas, visto que a programação orçamentária precisa ter como foco atingi-las. Na hipótese do relatório de prestação de contas informar os recursos que devem ser aplicados na vigência do PPA, os conselheiros teriam melhor capacidade de planejar suas atividades no sentido de acompanhar e fiscalizar a aplicação dos recursos, inclusive propondo adequações e melhorias para atender às necessidades (GONÇALVES et al., 2013). Dessa forma, o monitoramento do atendimento às necessidades da população poderia ocorrer com maior fluidez, dado que os conselheiros teriam acesso às informações para planejarem suas atividades e cumprirem suas atribuições.

Esse tipo de informação foi apresentado de maneira parcial em Goiás, tendência média, ao passo que Mato Grosso não apresentou recursos a serem aplicados na vigência do PPA. No entanto, Mato Grosso do Sul apresentou esse aspecto de maneira completa, possibilitando, portanto, maior capacidade dos conselheiros se planejarem. Para Ackoff et. al. (1984) o ato de planejar se refere à capacidade de se decidir antecipadamente sobre determinados aspectos. No caso dos Conselhos de Saúde os relatórios de prestações de contas devem permitir que os conselheiros possam decidir de forma antecipada sobre aspectos relativos ao atendimento das necessidades da saúde.

Ainda no aspecto avaliação das necessidades cumpre-se destacar a comparação com as variáveis evidenciação da aplicação de recursos financeiros (var 03 - ampla - divulgação obrigatória), especificação da fonte dos recursos financeiros (var 04 - ampla - divulgação obrigatória), pois para que possa haver qualquer monitoramento ou intervenção em relação ao atendimento às necessidades da população é necessário que os recursos financeiros aplicados sejam apresentados, inclusive identificados por fontes, além da sua destinação para determinados programas e ações. Nessa linha, entende-se que o relatório de prestação de contas possui a qualidade necessária, pois apresenta as informações adequadas. 
Contudo, ao fazer a conexão com outro indicador da amplitude participação mobilização de recursos - fica clara a falta de ação do Conselho no sentido de participar do controle de gastos da gestão da saúde em Goiás. Para justificar a respectiva afirmação cita-se o caso de devolução de recursos. Caso houvesse controle dos gastos orçamentários esse tipo de situação tenderia a não existir. Com efeito, surge um questionamento quanto ao fato do CES acompanhar o atendimento das necessidades da comunidade, pois mesmo a avaliação destas sendo feita não há garantia de que o necessário para cumprir a finalidade de atender a população está sendo controlado, ou seja, que a aplicação e recursos está sendo realizada de forma a suprir as necessidades da saúde da sociedade. Para Demo (2001) a participação é uma forma de intervir na realidade que permeia a própria vida dos indivíduos. Portanto, a participação nesse caso deveria intervir a ponto de fazer com que os recursos fossem aplicados no sentido de atender à comunidade.

Esse panorama - das necessidades nem sempre serem atendidas - também se corrobora pela não participação do Conselho nas decisões da Secretaria de Saúde (var 05 restrita - informação voluntária). Ocorre situação similar no CES/MT, onde verificam-se cobranças para que melhorias propostas pelo Conselho sejam efetivadas pela Secretaria - sem que a mesma encaminhe as devidas respostas e promova adequações, ou seja, não há ambiente favorável de colaboração entre as instituições. No caso de Mato Grosso do Sul o ambiente de controle social se mostra mais favorável no sentido de que existe mais cooperação entre as instâncias de poder, por exemplo, Ministério Público, CES e SES; apesar da variável 05 também apresentar tendência restrita neste Estado. A diferença em Mato Grosso do Sul é que quando o gestor se mostra indiferente às deliberações do CES para com a Secretaria, se buscam outras vias para compelir o mesmo a prestar contas de seus atos, conseguindo-se, dessa forma, melhores resultados que os outros Estados.

Por outro lado, cita-se um ponto considerado como positivo: a evidenciação do conteúdo legal (informação obrigatória), dado que a disponibilização das informações conforme legislação podem auxiliar os conselheiros no cumprimento de suas atribuições. A tendência para essa variável foi considerada média, o que, em tese, apresentaria um cenário próximo do mais adequado. Contudo, a apresentação das informações como visto anteriormente não tem garantido uma participação mais ampla por parte do CES/GO. Dessa forma, ao considerar a falta de controle dos gastos por parte da comunidade, a não representação da comunidade por parte do CES, relativa a avaliação das necessidades, e, por fim, um ambiente 
de controle social sem a cooperação de outras instâncias de poder, apresenta-se um cenário cuja necessidade de mudanças estruturais se mostra necessária. Dentro dessa ótica, os Conselhos, considerados como instancias participativas, devem ser os responsáveis por reunir atores políticos para definir estratégias e, por consequência, direcionar sua atuação no sentido de promover o processo participativo (GIOVANELLA, 2008). No entanto, o que foi possível verificar a partir das tendências de amplitude de participação social e qualidade da informação contábil é que a atuação do conselho não é suficiente para nortear a atuação do gestor da saúde, tampouco estabelecer uma relação de cooperação.

Em relação ao indicador liderança constatou-se que o gestor da saúde atua de maneira independente em relação ao CES, ou seja, de forma autoritária. Isto fica mais claro quando se analisam as categorias intermediárias "deliberações não homologadas pelo governo do Estado" e "decisões que buscam benefícios para a comunidade, mas sem efetividade". Esses aspectos acabam contribuindo para que a variável 10 - divulgação de pontos que necessitam de melhoria (informação voluntária) - não seja evidenciada, em virtude da falta de neutralidade do gestor em apresentar o que deve ser evidenciado. A neutralidade revela o caráter de imparcialidade dos gestores, ou seja, não se pode escolher determinadas informações por conveniência (GLAUTIER; UNDERDOWN, 2001). A var 10 é uma informação voluntária e exibe o fato do gestor atuar de maneira independente e neutra, ou seja, de maneira imparcial. No caso de Mato Grosso ocorreu a mesma situação, pois o também ficou caracterizada a independência do gestor, bem como a ausência de neutralidade.

Já em Mato Grosso do Sul apesar da liderança ter apresentado também tendência média - gestor de saúde atua de forma independente - nos relatórios de prestações de contas foram apresentados pontos que necessitavam de melhoria. A diferença de Mato Grosso do Sul para os demais Estados, no aspecto da liderança, é que as deliberações do CES quando não acatadas, em princípio, pelo gestor, encontram maior cooperação de outras instâncias de poder para induzir o Secretário de Saúde a seguir as recomendações do Conselho. A categoria teórica intermediária "Deliberações do CES trazem benefícios para a comunidade" corrobora o cenário de maior cooperação entre o Conselho e outros atores sociais, pois a suas deliberações acabam trazendo mais benefícios que nos outros Estados, conforme análise das entrevistas com os conselheiros.

No intuito de buscar elementos que possam apresentar indícios para que a participação social do Conselho não possibilite maior qualidade da informação - transparência 
das ações do gestor - foram verificados alguns aspectos do ambiente de controle social do Estado de Goiás, via análise das atas plenárias, quais sejam: a) decisões tomadas pelo gestor da saúde sem prévia consulta ao Conselho de Saúde; b) deliberações do Conselho de Saúde sem as respectivas homologações do governo Estado, fato que prejudica o encaminhamento de melhorias para a sociedade; c) morosidade de outras instâncias de poder (Ministério Público, Tribunal de Contas, Ministério da Saúde, entre outros) em atender as reivindicações do CES; d) municípios com prestações de contas não apresentadas e com risco de não receberem recursos do Ministério da Saúde; e) interesses políticos na gestão da saúde e, por conseguinte, redução na transparência das ações; f) falta de tempestividade da SES/GO em apresentar informações relevantes ao Conselho - via prestações de contas; g) atuação tímida do Ministério da Saúde em termos de gestão junto ao Estado; e h) falta de planejamento na gestão das prioridades da saúde, beneficiando, assim, pontos de interesse dos gestores.

Ademais, é importante destacar que o perfil dos conselheiros entrevistados apresenta características de indivíduos com níveis diferentes de escolaridade (cerca de cinco conselheiros sem nível superior - 55\% dos entrevistados - seguimento usuários); com tempo médio de atuação no CES de quatro anos e com dificuldade de avaliação dos relatórios de prestação de contas. Na percepção dos conselheiros não são realizados muitos cursos de capacitação para leitura dos relatórios. Todavia, os mesmos afirmaram que a qualidade dos relatórios não permite fácil entendimento da aplicação dos recursos. À luz dessa questão cumpre-se salientar que determinadas informações não demandam capacitação técnica prévia para compreender a alocação de recursos, como, por exemplo, a execução de recursos para programas definidos pelo Plano Estadual de Saúde, desde que divulgada de uma forma adequada ao público a que se destina. Sendo assim, caso o relatório esteja revestido das características qualitativas da informação contábil é possível avaliar determinadas informações dos relatórios de prestação de contas, mesmo sem ter conhecimento técnico específico da área contábil.

Em razão do exposto sobre o perfil dos conselheiros de Goiás, cabe mencionar à questão do CES não ter voz junto à Secretaria, em princípio, apresentar um cenário no qual a participação dos mesmos parece não ser suficiente para induzir o gestor a cumprir as deliberações do Conselho, tampouco atuar de forma parceira junto às instâncias de controle (MP, TC, por exemplo). 
Após apresentação do ambiente de controle social do Estado de Goiás é possível considerar que a qualidade restrita dos relatórios de prestações de contas, mesmo com determinado nível de participação social do CES, pode estar ancorada em elementos relativos à falta de cooperação de instâncias de controle e fiscalização da gestão da saúde, bem como a aspectos de interesses políticos imbricados na atuação de diversos atores da sociedade. Por oportuno, destaca-se que o relatório de prestação de contas pode ser considerado como resultado da ação anterior desses diversos atores. No entanto, de acordo com Pacheco (2004, p. 4) a accountability pode ser entendida como "obrigação permanente de prestar contas sobre o uso de recursos públicos, os resultados alcançados, e os critérios de decisão utilizados". Em face da conjuntura exposta, a SES/GO além de atuar de maneira independente em relação ao CES não divulga boa parte das informações necessárias para o cumprimento das atribuições dos conselheiros de saúde.

Por outro lado, salienta-se que o conteúdo das prestações de contas apresenta a forma como a saúde está sendo gerida no Estado, o que, no caso de Goiás, exibe a necessidade de melhoria tanto da qualidade dos relatórios quanto do ambiente de controle social, para que, a partir de então, existam meios para os aspectos qualitativos sejam incrementados pela participação social dos conselheiros. Por fim, ressalta-se que as características apresentadas pelo quadro 23, relativas às categorias teóricas intermediárias e as tendências dos indicadores de participação, vão ao encontro de uma amplitude de participação social que não proporciona maior qualidade na prestação de contas, haja vista que -apesar de apresentar sinais de participação dos conselheiros - essa participação pelo estágio ao qual se encontra, não proporciona ações a ponto de interferir em melhorias para a população, ao menos no que tange a maior transparência por meio dos relatórios de prestação de contas.

Como justificativa para esse cenário também deve ser considerada a questão do Conselho, aparentemente, não ter voz junto à Secretaria, e portanto, não há na realidade um ambiente participativo. O fato do CES não ter voz remete ao indicador de liderança (p. 97), pois não consegue fazer com que o gestor atue como parceiro, pelo contrário, o mesmo acaba atuando de maneira independente. Dessa forma, a intenção depreendida do âmbito da legislação, quando da criação de espaços participativos - Conselhos - parece não ampliar a participação a ponto de interferir no processo decisório para mudar ou construir uma nova agenda pública para a saúde (FUKS; PERISSINOTTO, 2006). 
Além disso, ressalte-se a questão do gestor divulgar praticamente só o que foi imposto por legislação. A não divulgação dos aspectos voluntários nas prestações de contas enfatiza a falta de uma participação social mais ativa por parte do CES, visto que não há incentivo suficiente para fazer com que o gestor possa divulgá-los voluntariamente. Indo mais além, vale mencionar que no Estado de Goiás não configura um ambiente de maior cooperação entre as instâncias de poder no sentido de compelir o gestor a ser mais transparente, cenário este semelhante ao que Campos (1990) já tratava em seu ensaio teórico. Com efeito, para Goiás ainda é preciso buscar maior amplitude da participação em relação ao processo deliberativo (FLEURY;LOBATO, 2009).

4.3.2 Amplitude da participação social do CES/MT e a Qualidade da Informação das Prestações de Contas da SES/MT

O quadro 24 apresenta o resultado da amplitude de participação social do CES e a qualidade dos relatórios de prestações de contas da SES de Mato Grosso. A amplitude de participação social chegou a uma tendência médialaberta, ao passo que a tendência de qualidade da informação apresentou-se como restrita, ou seja, de baixa qualidade. 
Mato Grosso

\begin{tabular}{|c|c|c|}
\hline \multicolumn{3}{|l|}{ Amplitude de Participação Social } \\
\hline Implantação e departamentalização - Categorias teóricas intermediárias & \multicolumn{2}{|c|}{ Tendência } \\
\hline $\begin{array}{l}\text { - Criado pela Lei Complementar 22/1992; } \\
\text { - Criação de comis sões para monitorar municípios; } \\
\text { - Relação entre o CES e a Secretaria apresenta pontos postivos; } \\
\text { - Comissões flexíveis para captar demandas; } \\
\text { - Deliberações do CES não homologadas pelo governador; } \\
\text { - Produção de melhorias para a comunidade. }\end{array}$ & \multicolumn{2}{|c|}{ Média } \\
\hline Avaliação das necessidades - Categorias teóricas intermediárias & \multicolumn{2}{|c|}{ Tendência } \\
\hline $\begin{array}{l}\text { - Avaliação das necessidades por múltiplos canais; } \\
\text { - Busca representar o ponto de vista da comunidade; } \\
\text { - Comissão estabele cooperação técnica com municípios para avaliar necessidades; }\end{array}$ & \multicolumn{2}{|c|}{ Aberta } \\
\hline Liderança - Categorias teóricas intermediárias & \multicolumn{2}{|c|}{ Tendência } \\
\hline $\begin{array}{l}\text { - Conselheiros bem articulados; } \\
\text { - Liderança de movimentos populares; } \\
\text { - Pessoas vitalícias; } \\
\text { - Decisões em favor da comunidade, mas muitas vezes sem efetividade; } \\
\text { - Deliberações não homologadas pelo gestor. }\end{array}$ & \multicolumn{2}{|c|}{ Média } \\
\hline Mobilização de recursos - Categorias teóricas intermediárias & \multicolumn{2}{|c|}{ Tendência } \\
\hline $\begin{array}{l}\text { - Estado aplica percentual inferior a } 12 \% \\
\text { - Municípios com problemas no repasse; } \\
\text { - O gestor estadual "apresenta" contas sobre os recursos aplicados; } \\
\text { - A população apenas acompanha a aplicação de recursos. }\end{array}$ & \multicolumn{2}{|c|}{ Média } \\
\hline Variáveis da Qualidade da Informação & Pacote & Tendência \\
\hline Variável (1) - Recursos pres vistos na proposta/lei orçamentária & Vo. & Restrita \\
\hline Variável (2) - Confronto dos resultados com as metas estabelecidas para área de saúde & Dob. & Média \\
\hline Variável (3) - Evidenciação da aplicação dos recursos financeiros & Ob. & Ampla \\
\hline Variável (4) - Especificação da fonte dos recursos financeiros & Ob. & Ampla \\
\hline Variável (5) - Participação do Conselho nas decisões da Secretaria de Saúde & Vo. & Restrita \\
\hline Variável (6) - Objetivos e Metas para o exercício subsequente? & Vo. & Restrita \\
\hline Variável (7) - Divulgação das prioridades para destinação dos recursos financeiros & Vo. & Restrita \\
\hline Variável (8) - Evidenciação das retificações orçamentárias & Dob. & Média \\
\hline Variável (9) - Previsão de recursos para os exercícios compreendidos no PPA para a área da saúde & Ob. & Restrita \\
\hline Variável (10) - Divulgação dos pontos que necessitam de melhorias & Vo. & Restrita \\
\hline Variável (11) - Evidenciação do conteúdo legal & Ob. & Média \\
\hline Variável (12) - Periodicidade de disponibilização dos relatórios & Vo. & Restrita \\
\hline Variável (13) - Disponibilização do relatório em análise & Ob. & Média \\
\hline
\end{tabular}

Quadro 24- Análise do resultado das tendências de amplitude de participação social e qualidade da informação em Mato Grosso

Fonte: elaborado pelo autor.

Legenda

Ob. - Divulgação obrigatória em virtude de legislação.

Dob. - Divulgação decorrente da obrigatoriedade contida em legislação (periférica).

Vo. - Divulgação voluntária por parte do gestor.

A visualização do quadro permite verificar que, assim como em Goiás, só houve qualidade, variáveis com tendência média/ampla, em aspectos pontuais pelo fato da legislação exigir a divulgação desse tipo de informação. Como forma de elucidar o foco na divulgação de variáveis obrigatórias verificou-se que $43 \%$ do total de variáveis foram classificadas com tendência médialampla (28\% médias/15\% amplas), ao passo que o percentual de variáveis 
obrigatórias, antes de qualquer classificação, dentro do instrumento de evidenciação, totalizou $38 \%$. Cabe ressaltar que o a qualidade dos relatórios de Goiás, apesar de terem chegado a 41\%, praticamente igual a Mato Grosso, há que se fazer uma distinção entre eles.

O ocorre que Mato Grosso apresentou qualidade da informação um pouco superior, também pelo fato das variáveis com tendência ampla, no período de 2011 a 2013, terem sido verificadas com maior frequência que Goiás. Além disso, houve divulgação de aspectos decorrentes de obrigação legal, fato que não ocorreu em Goiás. Adicionalmente, cabe salientar que das 13 variáveis que compõem o instrumento de evidenciação (100\%), cinco consideradas obrigatórias perfazem $38 \%$ do total. Assim, ficou caracterizada, novamente, a proximidade da qualidade da informação encontrada em relação ao percentual de variáveis obrigatórias, que só são divulgadas por imposição legal.

Além disso, cumpre-se salientar que nenhuma das variáveis de divulgação voluntária foi verificada, ou seja, todas exibiram tendência restrita. Dessa forma, ao analisar o resultado geral dos aspectos qualitativos da informação foi possível verificar que os relatórios de prestação de contas têm qualidade restrita - oito variáveis restritas de um total de 13, cerca de 61,50\%, assim como em Goiás, não foram divulgadas. De acordo com Nazário, Silva e Rover (2012) a qualidade da informação é pré-requisito essencial para que haja efetiva transferência de conhecimento e informações. Para o caso de Mato Grosso a falta de qualidade da informação, portanto, não possibilita a efetiva transferência de informações e conhecimento acerca da gestão da saúde pública no Estado.

No que se refere aos resultados das tendências de amplitude de participação social e da qualidade da informação das prestações de contas para o Estado de Mato Grosso considerou-se que a participação médialaberta do CES não promoveu maior qualidade para os relatórios. Diante disso, destaca-se que não houve divulgação do conjunto de informações voluntárias, mesmo caso de Goiás, fator o qual esperava-se que promovesse uma participação mais ativa e qualificada por parte do CES, em virtude de demonstrar, em tese, atuação mais neutra e parceira por parte do gestor. O gráfico 10 é responsável por apresentar os indicadores de amplitude de participação social do CES em face das variáveis de qualidade da informação dos relatórios da SES. A partir deste e do quadro 24 são discutidos, de forma pontual, indicadores, categorias teóricas intermediárias da amplitude de participação social e variáveis da qualidade da informação, todos pertencentes aos dois instrumentos de pesquisa utilizados neste trabalho. 


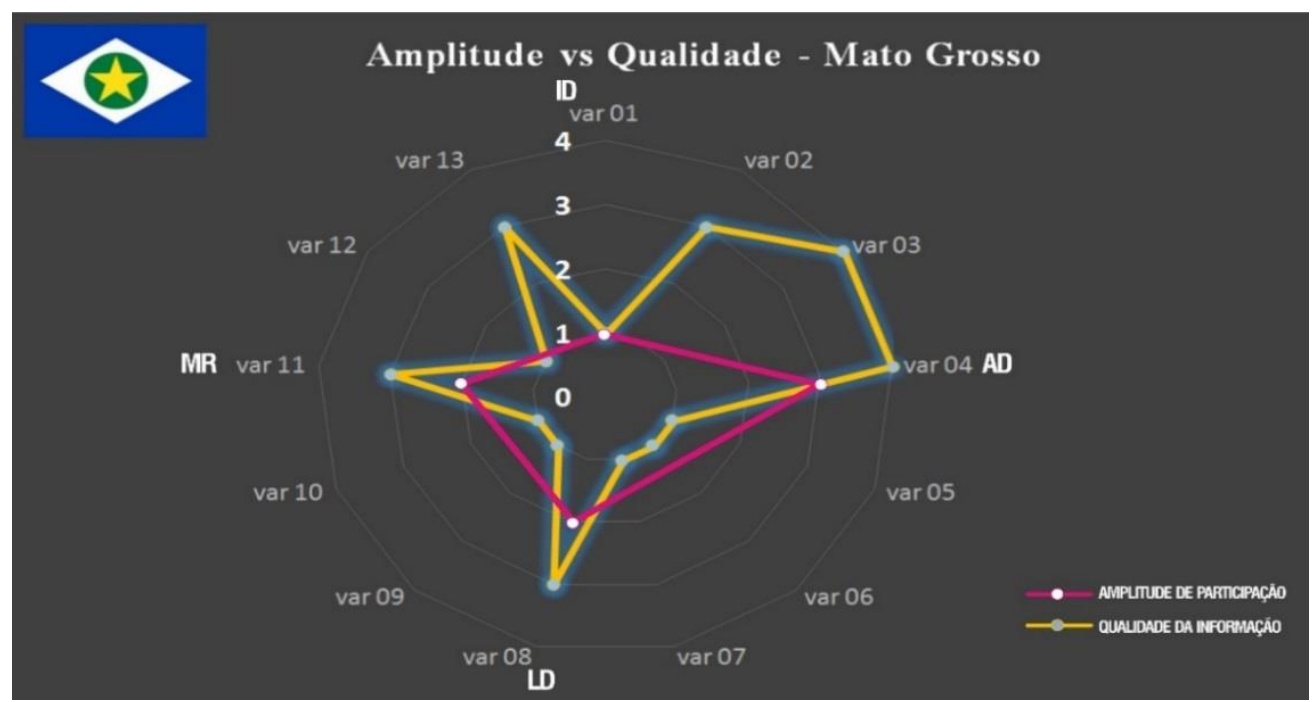

Gráfico 10 -Amplitude de participação social vs Qualidade da Informação - Mato Grosso. Fonte: elaborado pelo autor.

Das variáveis da qualidade da informação que podem incrementar a participação social do CES é possível destacar as seguintes: confronto dos resultados com a metas estabelecidas para a área de saúde (var 02 - média - decorrente da obrigatória), evidenciação da aplicação de recursos financeiros (var 03 - ampla - divulgação obrigatória), especificação da fonte dos recursos financeiros (var 04 - ampla - divulgação obrigatória)e evidenciação do conteúdo legal (var 11 - média - divulgação obrigatória). Nota-se que os aspectos destacados, estão ligados à divulgação obrigatória e decorrente dela, fator que indica um ambiente não tão participativo a ponto de fazer com que o gestor divulgue informações de maneira voluntária. Apesar da tendência de amplitude de participação social ter sido considerada médialaberta, esta parece não ser suficiente para compelir o gestor estadual de saúde a ser mais transparente. A participação social pode promover o controle público por meio da accountability, com vistas a incentivar maior transparência e adequação das atividades às necessidades de saúde local (OLIVERA, 2004; REZENDE, 2013).

Dos aspectos destacados, cumpre-se salientar que o confronto dos resultados com as metas traçadas permite que os conselheiros possam atuar no sentido de verificar se a gestão está cumprindo aquilo que foi preconizado, bem como promover sugestões de melhorias e adequações para o gestor da saúde. Nesse cenário é possível interligar alguns indicadores de amplitude de participação social como, por exemplo: avaliação das necessidades, liderança e mobilização de recursos. 
O primeiro indicador - avaliação das necessidades, com tendência aberta, onde o CES representa a comunidade e avalia suas necessidades - se analisado a partir de uma comparação com a var 10 (divulgação dos pontos que necessitam de melhorias - divulgação voluntária) - quesito não praticado pela SES -, apresenta a ausência do Conselho no tocante ao estabelecimento de parceira com a Secretaria para que sejam divulgados nos relatórios pontos que possam ser melhorados e como efetivamente seriam em virtude das necessidades da população. A questão é que, ao saber das necessidades da população e possuir uma relação participativa frente à Secretaria o Conselho, pode instigar o gestor a divulgar possíveis pontos de melhoria em relação às necessidades da população que não estão sendo atingidas. $\mathrm{O}$ mesmo cenário foi verificado em Goiás.

Esse panorama também é corroborado pela não participação do Conselho nas decisões da Secretaria de Saúde (var 05 - restrita - divulgação voluntária). As entrevistas e pareceres permitiram verificar que existem sucessivas cobranças para que melhorias propostas pelo CES sejam efetivadas. Algumas delas chegam a ser realizadas. Todavia, isso só ocorre após cobranças continuadas, deixando claro, portanto, a não transparência do gestor. Para Pinho (2008) a accountability, de maneira aproximativa, pode ser visualizada como a transparência. Portanto, a falta de respostas às solicitações do CES configura um ambiente no qual o aspecto da accountability parece estar fora do foco. Na realidade, isso demonstra uma característica do todo, na qual o Conselho não consegue ter voz junto à Secretaria e, portanto, não há na realidade um ambiente participativo. No caso, o aspecto da liderança pode ser explorado a partir desse cenário.

Dessa forma, em relação ao indicador liderança constatou-se que o gestor da saúde atua de maneira independente em relação ao CES, ou seja, de forma autoritária. Isto fica mais claro quando são analisadas as categorias intermediárias "deliberações não homologadas pelo governo do Estado" e "decisões que buscam benefícios para a comunidade, mas sem efetividade". Esses aspectos acabam contribuindo para que a variável 10 - divulgação de pontos que necessitam de melhoria (informação voluntária) - não seja divulgada, em virtude da falta de neutralidade do gestor em apresentar o que deve ser evidenciado. Glautier e Underdown (2001) afirmam que neutralidade revela o caráter de imparcialidade dos gestores, ou seja, não se pode escolher determinadas informações por conveniência. Em Mato Grosso a falta de neutralidade indica que a divulgação de determinadas informações pode apresentar caráter de conveniência de divulgação das informações por conta do gestor. Essa situação se assemelha a 
Goiás. Somente Mato Grosso do Sul apresentou cenário um pouco diferente em virtude de uma maior cooperação de outras instâncias de poder para induzir o Secretário de Saúde a seguir as recomendações do Conselho.

Já o indicador mobilização de recursos sugere um cenário visto possivelmente como contraditório. Ocorre que apesar dos recursos serem apresentados por programas e ações, inclusive indicando as fontes de recursos, a fiscalização do CES não se mostra qualificada a ponto de controlar a aplicação de recursos, fato que remete a uma tendência média- existe repasse periódico da União, Estado e Municípios, mas a população não participa de forma a controlar os gastos. Assim como no Estado de Goiás há uma falta de controle dos gastos por parte da comunidade. As categorias teóricas intermediárias "o gestor estadual apresenta contas sobre os recursos aplicados" e "a população apenas acompanha a aplicação de recursos" enfatizam a ideia de que não há controle dos gastos.

A diferença entre Goiás e Mato Grosso está nos aspectos da avaliação das necessidades, pois o CES/MT, de acordo com as categorias teóricas intermediárias "busca representar o ponto de vista da comunidade" e possui comissões que "estabelecem cooperação técnica com municípios para avaliar as necessidades". O fato do Conselho representar a comunidade acaba por instigar questionamento relativo à efetividade do atendimento às demandas da população, dado que para ser efetivo é preciso controlar os gastos - fato que não ocorre no Estado de Mato Grosso. Soma-se a esse panorama o fato do ambiente de controle social não promover maior fiscalização e controle das ações do gestor da saúde. Novamente, destaca-se a necessidade de mudanças estruturais no sentido de buscar cooperação com outras instâncias de poder, bem como com outras entidades que permeiem a discussão controle social da saúde.

No intuito de buscar elementos que possam apresentar indícios para que a participação social do Conselho não possibilitar maior qualidade da informação - transparência das ações do gestor - foram verificados alguns aspectos do ambiente de controle social, de acordo com a análise das atas plenárias, do Estado de Mato Grosso, a saber: a) desconformidades e improbidades cometidas pela SES/MT; b) despesas liquidadas e não pagas, o que apresenta problemas na execução das metas; c) descaso do governo no quesito repasse de verbas financeiras para OS, em detrimento dos hospitais públicos; d) falta de apoio de outras instâncias de poder (ainda em relação ao item “c”); e) falta de estabelecimento de prioridades 
para a saúde; f) judicialização da saúde; g) falta de vontade política em mudar o quadro da saúde.

Adicionalmente, reitera-se que o perfil dos conselheiros entrevistados, assim como em Goiás, apresentou características de indivíduos com níveis diferentes de escolaridade (cerca de cinco conselheiros com nível superior - $56 \%$ dos entrevistados - e quatro sem nível superior - 44\% dos entrevistados - pertencentes ao seguimento usuários) e tempo médio de atuação no CES de seis anos. A partir das entrevistas, foi possível identificar que não são realizados cursos periódicos de capacitação para leitura dos relatórios, o que delega grande parte desta atribuição somente para a Comissão de Orçamento e Finanças. Apesar de uma certa dificuldade de leitura dos relatórios por parte dos conselheiros os relatórios se mostram um pouco melhores dos que os de Goiás, principalmente em virtude das variáveis confronto dos resultados com as metas estabelecidas para área de saúde e evidenciação das retificações orçamentárias. Em face do exposto, o perfil dos conselheiros de Mato Grosso aliado à questão do CES não ter voz junto à Secretaria, em princípio, apresenta um cenário no qual a participação dos mesmos parece não ser suficiente para impeliro gestor a cumprir as deliberações do Conselho, tampouco atuar de forma parceira junto às instâncias de controle (MP, TC, por exemplo).

Após essa incursão no ambiente de controle social do Estado de Mato Grosso foi possível considerar que a qualidade restrita dos relatórios de prestações de contas, mesmo com participação social média/aberta do CES, pode, novamente, estar ancorada em elementos relativos à ausência de cooperação entre as instâncias de controle e fiscalização da gestão da saúde. Oportunamente considera-se o argumento de Strong et al. (1997) no tocante à possibilidade de informações com qualidade inferior poderem gerar impactos significativos para área social. Nesse contexto, é possível visualizar que os referidos impactos na área social possuem conexão com o ambiente de controle social da saúde, onde há necessidade de participação social do CES para fiscalizar os relatórios de prestações de contas, o que, por consequência, deveria melhorar a qualidade destes.

Por oportuno, destaca-se que o ambiente de controle social apresentado gera implicações similares ao ocorrido nos relatórios de prestação de contas da SES/GO, dado que estes também seriam fruto da ação anterior desses diversos atores - que, aliás, não atuam de maneira conjunta no sentido de promover controle das ações do gestor, conforme relatos apresentados. Dessa forma, a necessidade de melhoria tanto da qualidade da informação quanto do ambiente de controle social fica em evidência no Estado de Mato Grosso. 
Por fim, assim como em Goiás, ressalte-se a questão do gestor divulgar praticamente só o que foi imposto por legislação. Sendo assim, a não divulgação dos aspectos voluntários enfatiza a falta de uma participação social qualificada por parte do CES, visto que não há incentivo suficiente para fazer com que o gestor possa divulgá-los voluntariamente. $\mathrm{Na}$ esteira dessas evidências, vale mencionar que no Estado de Mato Grosso não configura um ambiente de maior cooperação entre as instâncias de poder no sentido de compelir o gestor a ser mais transparente. Dessa forma, para Mato Grosso ainda é preciso buscar maior amplitude da participação social em relação ao processo deliberativo (FLEURY; LOBATO, 2009).

4.3.1 Amplitude da participação social do CES/MS e Qualidade da Informação das Prestações de Contas da SES/MS

O quadro 25 apresenta o resultado da amplitude de participação social do CES e a qualidade dos relatórios de prestações de contas da SES de Mato Grosso do Sul. A amplitude de participação social chegou a uma tendência médialaberta, assim como em Mato Grosso, ao passo que a tendência de qualidade da informação apresentou-se como média, ou seja, houve participação em face de uma maior qualidade dos relatórios. 
Mato Grosso do Sul

\begin{tabular}{|c|c|c|}
\hline \multicolumn{3}{|l|}{ Amplitude de Participação Social } \\
\hline Implantação e departamentalização - Categorias teóricas intermediárias & \multicolumn{2}{|c|}{ Tendência } \\
\hline $\begin{array}{l}\text { - Criado pelo Decreto 1595/1989; } \\
\text { - Criação da comissão de AIDS, Doenças Raras e Controle Social; } \\
\text { - Comissões flexíveis, inclusive para agregar novos atores; } \\
\text { - Cooperação com outras organizações da comunidade; } \\
\text { - Mudanças ocorridas produzem melhorias. }\end{array}$ & \multicolumn{2}{|c|}{ Média } \\
\hline Avaliação das necessidades - Categorias teóricas intermediárias & \multicolumn{2}{|c|}{ Tendência } \\
\hline $\begin{array}{l}\text { - Avaliação das necessidades por múltiplos canais; } \\
\text { - Hierarquia de solicitações pelos Forúns; } \\
\text { - Usuários, forúns, CES pautam assuntos; } \\
\text { - Demandas do PES são discutidas nas plenárias. }\end{array}$ & \multicolumn{2}{|c|}{ Aberta } \\
\hline Liderança - Categorias teóricas intermediárias & \multicolumn{2}{|c|}{ Tendência } \\
\hline $\begin{array}{l}\text { - Conselheiros bem articulados; } \\
\text { - Líderes natos; } \\
\text { - Pessoas vitalícias; } \\
\text { - Deliberações do CES trazem benefícios para a comunidade; } \\
\text { - Gestor não homologa as deliberações do CES; } \\
\text { - Liderança de movimentos populares. }\end{array}$ & \multicolumn{2}{|c|}{ Média } \\
\hline Mobilização de recursos - Categorias teóricas intermediárias & \multicolumn{2}{|c|}{ Tendência } \\
\hline $\begin{array}{l}\text { - Estado aplica percentual inferior a } 12 \% \text {; } \\
\text { - Municípios que gastam de } 20 \% \text { a } 25 \% \text { de suas receitas com a saúde por conta do Estado aplicar menos de } \\
12 \% \text {; } \\
\text { - Gestor apenas apresenta contas ao CES; } \\
\text { - A população apenas acompanha a aplicação de recursos. }\end{array}$ & \multicolumn{2}{|c|}{ Média } \\
\hline Variáveis da Qualidade da Informação & Pacote & Tendência \\
\hline Variável (1) - Recursos presvistos na proposta/lei orçamentária & Vo. & Restrita \\
\hline Variável (2) - Confronto dos resultados com as metas estabelecidas para área de saúde & Dob. & Média \\
\hline Variável (3) - Evidenciação da aplicação dos recursos financeiros & Ob. & Ampla \\
\hline Variável (4) - Especificação da fonte dos recursos financeiros & Ob. & Ampla \\
\hline Variável (5) - Participação do Conselho nas decisões da Secretaria de Saúde & Vo. & Restrita \\
\hline Variável (6) - Objetivos e Metas para o exercício subsequente? & Vo. & Média \\
\hline Variável (7) - Divulgação das prioridades para destinação dos recursos financeiros & Vo. & Média \\
\hline Variável (8) - Evidenciação das retificações orçamentárias & Dob. & Média \\
\hline Variável (9) - Previsão de recursos para os exercícios compreendidos no PPA para a área da saúde & Ob. & Ampla \\
\hline Variável (10) - Divulgação dos pontos que necessitam de melhorias & Vo. & Ampla \\
\hline Variável (11) - Evidenciação do conteúdo legal & Ob. & Ampla \\
\hline Variável (12) - Periodicidade de disponibilização dos relatórios & Vo. & Restrita \\
\hline Variável (13) - Disponibilização do relatório em análise & Ob. & Restrita \\
\hline
\end{tabular}

QUADRO 25-Análise do resultado das tendências de amplitude de participação social e qualidade da informação em Mato Grosso do Sul

Fonte: elaborado pelo autor.

Legenda

Ob. - Divulgação obrigatória em virtude de legislação.

Dob. - Divulgação decorrente da obrigatoriedade contida em legislação (periférica).

Vo. - Divulgação voluntária por parte do gestor.

A visualização do quadro permite verificar que, diferentemente de Goiás e Mato Grosso, houve maior qualidade da informação, representada por variáveis com tendência médialampla, sobretudo nos aspectos ligados à divulgação voluntária. Como forma de elucidar a divulgação de variáveis voluntárias verificou-se que estas perfazem $46 \%$ do total de variáveis do instrumento, e para o Estado de Mato Grosso o percentual de variáveis classificado com tendência média/ampla, para este tipo de informação, chegou a 23\% (15\% médias/8\% amplas), 
ou seja, atingiu 50\% do total de variáveis voluntárias do instrumento de evidenciação. Em relação ao resultado esperava-se que quanto maior fosse a amplitude de participação social, maior seria o seria nível de divulgação de informações. Portanto, a qualidade tenderia a ser maior, sobretudo com respeito às variáveis de divulgação voluntária, dado que este tipo de informação representa, por exemplo, a neutralidade do gestor em divulgar os pontos que necessitam de melhorias na área da saúde. Logo, foi possível corroborar essa hipótese para Mato Grosso do Sul.

O gráfico 11 apresenta os indicadores de amplitude de participação social do CES em face das variáveis de qualidade da informação dos relatórios da SES. A partir deste e do quadro 25 são discutidos, de forma pontual, indicadores, categorias teóricas intermediárias da amplitude de participação e variáveis da qualidade da informação, ambos pertencentes aos dois instrumentos de pesquisa utilizados neste trabalho.

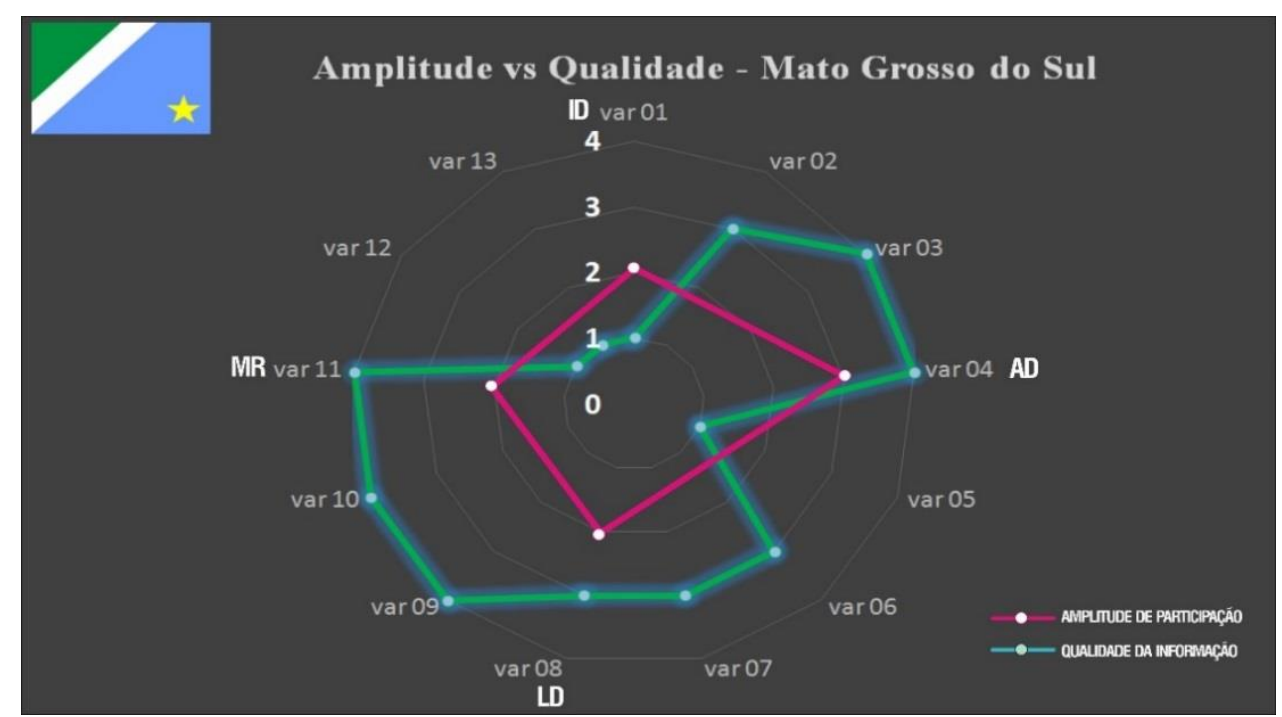

Gráfico 11 - Amplitude de participação social vs Qualidade da Informação - Mato Grosso do Sul.

Fonte: elaborado pelo autor.

Das variáveis da qualidade da informação que podem incrementar a participação social do CES é possível destacar as seguintes: confronto dos resultados com as metas estabelecidas para a área de saúde (var 02 - média - divulgação decorrente da obrigatória), evidenciação da aplicação de recursos financeiros (var 03 - ampla - divulgação obrigatória), especificação da fonte dos recursos financeiros (var 04 - ampla - divulgação obrigatória), objetivos e metas para o exercício subsequente (var 06 - média - divulgação obrigatória), 
divulgação das prioridades para destinação de recursos financeiros (var 07 - média), previsão de recursos para os exercícios compreendidos no PPA para a área da saúde (var 09 - ampla - divulgação obrigatória), divulgação dos pontos que necessitam de melhorias (var 10 - ampla - divulgação voluntária) e evidenciação do conteúdo legal (var 11 - ampla divulgação obrigatória). O confronto dos resultados com as metas traçadas permite que os conselheiros possam atuar no sentido de verificar se a gestão está cumprindo aquilo que foi preconizado, bem como promover sugestões de melhorias e adequações para o gestor da saúde (GONÇALVES et al., 2013). Nesse cenário, similar aos demais Estados, é possível interligar alguns indicadores de amplitude de participação social como: avaliação das necessidades, liderança e mobilização de recursos.

Ainda nessa linha, a questão da avaliação das necessidades da comunidade tem nas prestações de contas a oportunidade de verificar se aquilo que foi levantado como uma necessidade, efetivamente está recebendo alocação de recursos para ser atendida, bem como se está alinhada ao Plano Estadual de Saúde, como dito anteriormente. Para o caso da SES/MS é possível afirmar que houve evolução com respeito à divulgação dos montantes alocados na saúde, em consonância com o PPA e PES. Outro fator está ligado a questão da divulgação de remanejamentos realizados pelo gestor, que em alguns períodos foram apresentados e em outros não, mas de forma geral também houve uma evolução. Fatores como esses permitem ao conselheiro realizar acompanhamento dos recursos que serão aplicados, de modo que, quando necessário, possa propor melhorias ou adequações tendo como ponto focal as diretrizes do PES (GONÇALVES et al., 2011). Sob essa ótica, entende-se que existem indícios de que os relatórios, mesmo com as restrições relativas a sua qualidade - já mencionadas nos itens 4.2.1, 4.2.2 e 4.2.3 - abrem espaço ou condição um pouco mais favorável para o exercício do controle social praticado pelo CES/MS.

Ainda com relação ao primeiro indicador - avaliação das necessidades, com tendência aberta, onde o CES representa a comunidade e avalia suas necessidades - se analisado a partir de uma comparação com as variáveis: 09 (previsão de recursos para os exercícios compreendidos no PPA para a área da saúde - divulgação obrigatória), 10 (divulgação dos pontos que necessitam de melhorias - divulgação voluntária) exibem cenário mais propício ao cumprimento das atribuições legais dos conselheiros, dado que existem subsídios melhores para avaliação da gestão da saúde. O que se tem como ganho a partir da divulgação de recursos compreendidos na vigência do PPA é que o planejamento das atividades dos conselheiros, inclusive no sentido propor melhorias e adequações, possui mais informações 
para ser desenvolvido. As categorias teóricas intermediárias de avaliação das necessidades "hierarquia de solicitações pelos fóruns", "usuários e fóruns pautam assuntos" e "demandas do PES são discutidas nas plenárias" parecem fazer parte de um conjunto de elementos que propicia um ambiente mais favorável à divulgação de variáveis voluntárias, como exemplo a $\operatorname{var} 10$

Por outro lado, cabe mencionar o aspecto da não participação do Conselho nas decisões da Secretaria de Saúde (var 05 - restrita - divulgação voluntária). Apesar de existirem cobranças no sentido de provocar melhorias a partir de deliberações do CES, muitas não são homologadas e quando isto ocorre aparecem outras instâncias de poder, que no caso de Mato Grosso do Sul, são mais atuantes, para compelir o gestor a efetivar mudanças. Contudo, a cooperação, em virtude da morosidade burocrática, com outras instâncias, não chega a resolver todos casos demandados pelo CES. Nesse sentido, existe um esforço para que as necessidades sejam atendidas. Apesar do nível de qualidade da informação ser melhor em Mato Grosso do Sul, ainda não é possível afirmar que o gestor transparente é na condução da saúde do Estado, pois ainda existem aspectos a serem melhorados, como, por exemplo, a periodicidade das prestações de contas (var 12 - divulgação voluntária), fator que muitas vezes faz com que a informação perca a sua relevância. Já o indicador - mobilização de recursos - indica um cenário novamente visto como contraditório. Ocorre que apesar dos recursos serem apresentados por programas e ações, inclusive indicando as fontes de recursos, a fiscalização do CES não se mostra atuante, fato que remete a uma tendência média para o indicador em epígrafe - existe repasse periódico da União, Estado e Municípios, mas a população não participa de forma a controlar os gastos da saúde pública.

Por oportuno, em relação ao indicador liderança constatou-se que o gestor da saúde atua de maneira independente em relação ao CES, ou seja, de forma autoritária. Isto fica mais claro quando se analisa a categoria teórica intermediária "gestor não homologa as deliberações do CES”. Contudo, há que se destacar iniciativas pontuais de divulgação voluntária por parte do gestor. É o caso da variável 10 - ampla - divulgação de pontos que necessitam de melhoria (informação voluntária). Ocorre que apesar do gestor atuar de forma independente, os relatórios de prestação de contas apresentam a divulgação de pontos que necessitam de melhoria. Todavia, a divulgação desses aspectos não garante que as mudanças sejam efetivadas, mas já apresenta uma evolução com respeito aos demais Estados. 
Assim como no Estado de Goiás e Mato Grosso existe a falta de controle dos gastos por parte da comunidade. Contudo, a avaliação das necessidades no CES/MS representa a comunidade, bem como no CES/MT. O fato do Conselho representar a comunidade instiga questionamento relativo à efetividade do atendimento às demandas da população, dado que para ser efetivo é preciso controlar os gastos - fato que merece destaque para o Mato Grosso do Sul. Adicionalmente, a consideração desse panorama somada ao ambiente de controle social com maior cooperação de outros atores apresenta maior transparência da gestão da saúde, mas que ainda sim padece de melhorias em determinados aspectos, sobretudo no controle dos recursos aplicados. A categoria teórica intermediária "gestor apenas apresenta contas ao CES" referente o indicador de mobilização de recursos apresenta a necessidade de melhoria, apesar de considerar que Mato Grosso Sul evidencia mais informações que os outros Estados pesquisados. Ocorre que a qualidade da informação dos demais ainda é restrita.

Em princípio, como dito anteriormente, é necessário discutir o ambiente de controle social existente no Estado de Mato Grosso Sul, pois a visão deste panorama pode auxiliar na compreensão da amplitude de participação média/aberta possibilitar maior qualidade dos relatórios de prestações de contas. Diante disso, foram verificados os seguintes aspectos relativos ao controle social: a) parceria do CES com outros atores sociais; b) realização de debates e encontros com outros atores sociais; c) busca por fornecimento de estrutura de trabalho dos conselhos saúde; d) formulação de ações para a saúde inserindo outros atores sociais; e) falta de conhecimento da população em geral sobre o que é controle social; f) busca pelo fortalecimento do controle social no estado; g) CES atuante, inclusive reprovando RAGs.

Adicionalmente, afirma-se que o perfil dos conselheiros entrevistados, assim como em Goiás e Mato Grosso, apresentou características de indivíduos com níveis diferentes de escolaridade (cerca de seis conselheiros com nível superior - 67\% dos entrevistados - e três conselheiros sem nível superior - 33\% dos entrevistados - seguimento usuários) e com tempo médio de atuação no CES de 6,5 anos. De acordo com a visão dos conselheiros também não são realizados cursos periódicos de capacitação para leitura dos relatórios, o que delega novamente grande parte desta atribuição somente para a Comissão de Orçamento. Apesar de uma certa dificuldade de leitura dos relatórios por parte dos conselheiros os relatórios se mostram melhores dos que os de Goiás e Mato Grosso, sobretudo se consideradas as variáveis com divulgação voluntária verificadas: objetivos e metas para o exercício subsequente, divulgação das prioridades para destinação de recursos financeiros e divulgação dos pontos que 
necessitam de melhoria. Em face do exposto o perfil dos conselheiros de Mato Grosso do Sul aliado à questão do CES não ter voz junto à Secretaria, diferentemente os outros Estados, apresenta um cenário no qual a participação dos mesmos induz o gestor a cumprir as deliberações do Conselho, em virtude de uma forma de atuação mais parceira junto às instâncias de controle (MP, TC, por exemplo), conforme Campos (1990) e O`Donnell (1998) mencionam.

Após a exposição do ambiente de controle social da saúde no Estado é possível visualizar que se busca a participação de outras instâncias na discussão de questões relativas às necessidades da saúde, o que favorece o cenário de controle das ações do Estado, bem como a análise de que a participação média do CES possibilitaria maior qualidade para os relatórios, quando este atua de forma conjunta com outros atores sociais. O Conselho em si não tem caráter punitivo, apenas propositivo. Nesse sentido, considera-se a ideia de que o relatório de prestação de contas é fruto da ação anterior desses diversos atores do controle social.

A partir desse cenário verifica-se que a participação social desenvolvida ao longo tempo, somado a um ambiente de controle social no qual existe maior cooperação de outros atores, possibilitou maior qualidade - no intervalo analisado (2011 a 2013) - para os relatórios, caracterizando, assim, tendência média. Cumpre-se salientar, novamente, que a amplitude de participação social - na figura da dimensão histórica - é fruto da sedimentação histórica de uma série de fatos e acontecimentos - (GRAMSCI, 1981) - que posteriormente podem ser traduzidos em maior qualidade das prestações de contas, pois na medida em que os conselheiros estão mais vigilantes, os gestores da saúde se veem na necessidade de prestar contas de seus atos para a sociedade. Na esteira dessas evidências, visualiza-se que o controle social da saúde exercido no Estado de Mato Grosso do Sul apresenta indícios de que se desenvolveu ao longo do tempo.

Por fim, diferentemente de Goiás e Mato Grosso, ressalte-se a questão do gestor divulgar informações além do que foi imposto por legislação. Sendo assim, a divulgação dos aspectos voluntários enfatiza uma participação social mais qualificada por parte do CES, visto que há incentivos para fazer com que o gestor possa divulgá-los voluntariamente. Na esteira dessas evidências, vale mencionar que no Estado de Mato Grosso do Sul se configura um ambiente de maior cooperação entre as instâncias de poder no sentido de compelir o gestor a ser mais transparente. No entanto, ainda é preciso buscar maior amplitude da participação, pois ainda há elementos para serem desenvolvidos no ambiente de controle social da saúde em Mato Grosso do Sul. 


\subsection{Considerações Iniciais dos Resultados}

As conclusões iniciais dos resultados discutidos nos estados da região Centro Oeste vão ao encontro de uma ideia em que a participação social dos Conselhos de Saúde pode incrementar a qualidade da informação dos relatórios das prestações de contas das SES. Para o caso de Goiás as tendências dos indicadores de amplitude indicaram um ambiente de menor participação se considerados os Conselhos de Mato Grosso e Mato Grosso do Sul. Além disso, a qualidade da informação dos relatórios de prestação de contas da SES/GO foi considerada restrita, inclusive com divulgação apenas de aspectos obrigatórios por legislação. Vale destacar que nenhum aspecto voluntário foi divulgado, ou seja, apresentou ambiente menos participativo e colaborativo entre a Secretaria e o CES. A partir do cenário exposto para o Estado de Goiás é possível considerar que pelo fato da participação social do CES não conseguir induzir o gestor a divulgar mais informações, sobretudo as de caráter voluntário, não consegue incrementar a qualidade da informação dos relatórios de prestação de contas, contudo em razão do estágio em que se encontra a amplitude de participação social naquele Estado.

Já no caso de Mato Grosso a amplitude de participação social apresentou alguma evolução em relação a Goiás - aspectos relativos a avaliação das necessidades. No entanto, em razão do estágio atual, a participação (caracterizada pela amplitude de participação) do CES não foi suficiente para incrementar a qualidade da informação das prestações de contas da SES/MT. Para que seja possível fazer um comparativo com a qualidade da informação de Goiás, considerando percentual de variáveis médias/amplas ${ }^{39}$, são apresentados os seguintes resultados: Goiás com 38,46\% de divulgação e Mato Grosso com 46,15\%. Apesar do incremento na evidenciação a qualidade ainda é considerada baixa para Mato Grosso, principalmente quando se verifica novamente que nenhuma variável voluntária foi evidenciada.

Aliás as variáveis voluntárias assumem papel importante para analisar a questão da participação, inclusive para revelar se existe um ambiente participativo em que o CES e a SES atuam com maior cooperação no atendimento às demandas da saúde. Além disso, vale lembrar que o percentual de qualidade da informação dos relatórios de prestações de contas de Mato

\footnotetext{
${ }^{39}$ Foram consideradas variáveis médias e amplas pelo fato destas representarem divulgação parcial ou total dos aspectos avaliados, respectivamente. Logo, considera-se que para verificar a qualidade é preciso que os itens sejam divulgados parcial ou totalmente.
} 
Grosso, apesar de ser superior ao de Goiás, só aumentou por conta de variáveis decorrentes das obrigatórias, ou seja, ainda em virtude de influência de lei. Portanto, para Goiás e Mato Grosso verificou-se que a participação não incrementou a qualidade, dado que só se cumpre o que é obrigatório e decorrente de obrigação legal, muitas vezes de maneira parcial.

Por oportuno, cabe ressaltar um paralelo existente entre o ambiente de controle social e accountability horizontal (PINHO; SACRAMENTO, 2009), pois a necessidade de se ter uma articulação entre o controle social e as instituições externas de controle parece não ocorrer de maneira adequada nos estados de Goiás e Mato Grosso. Em princípio os aspectos citados integram a discussão da participação dos Conselhos não incrementar a qualidade dos relatórios de prestação de contas das Secretarias, também por conta dos CES não conseguirem ter voz nas SES - situação em que os gestores atuam de maneira independente, tendência média para o indicador liderança.

O’Donnell (1998) argumenta que o Executivo, Legislativo, Judiciário, agências de supervisão e instancias responsáveis pela fiscalização das prestações de contas compõem a dimensão da accountability horizontal - que pressupõe o controle entre os poderes constituídos (perspectiva do checks and balances). Para o ambiente abordado nesta pesquisa vale mencionar que a accountability horizontal representa, por exemplo, a atuação do Ministério Público no sentido de agir, quando solicitado, para compelir o gestor da saúde a cumprir as deliberações dos Conselhos Estaduais de Saúde, ou seja, dar voz à liderança a ser exercida pelo CES.

Ainda nessa linha, Pinho e Sacramento (2009) consideram que o autoritarismo possui grande capacidade de se redesenhar em face de possíveis mudanças culturais e institucionais a favor do incremento da accountability, ou seja, parece ocasionar um efeito mutante para não dar espaço ao ato de prestar contas por parte dos gestores da saúde. Sob esse invólucro, verificou-se que atuação do Ministério Público e do Tribunal de Contas em Goiás e Mato Grosso parece não instigar a formação de um ambiente de cooperação com os CES.

Para Borges (2014, p. 10) "a operacionalização do controle social perpassa a questão da accountability”. Seguindo essa ótica, entende-se que o ambiente de controle social acaba não sendo operacionalizado, dado que a qualidade das prestações de contas de Goiás e Mato Grosso é restrita e a participação dos CES não é suficiente para fazer com que o gestor da saúde seja induzido a prestar contas da sua gestão, inclusive por não haver cooperação de outras instâncias de poder voltadas ao controle. É justamente este ponto que diferencia Mato 
Grosso e Mato Grosso do Sul, em virtude destes possuírem tendências de amplitude de participação similares. Para Mato Grosso do Sul é possível afirmar que a amplitude de participação do CES consegue, aliada a um maior ambiente de cooperação com outras instâncias de controle, induzir e compelir o gestor a ser mais transparente. A referida afirmação encontra embasamento no fato da qualidade da informação de Mato Grosso do Sul ter chegado a 66\% de evidenciação, inclusive com variáveis consideradas voluntárias.

Em se tratando de variáveis da qualidade da informação que possibilitam maior participação, cumpre-se salientar que a visualização, por exemplo, da aplicação de recursos apresentada por programas e ações (variável obrigatória) permite ao conselheiro verificar se os recursos estão sendo aplicados de acordo com Plano Estadual de Saúde. A partir daí os conselheiros de saúde tem maior possibilidade de avaliar o atendimento das necessidades da saúde conforme planejamento realizado no PES. Em casos de desconformidade o CES pode oferecer denúncias ao Ministério Público, caso o gestor da saúde não homologue as deliberações do Conselho que têm o intuito de buscar solucionar os problemas detectados. Por outro lado, pode-se citar também a variável que evidencia pontos que necessitam de melhoria (variável voluntária), aspecto que demonstra a neutralidade do gestor da saúde. A evidenciação deste tipo de variável permite aos conselheiros avaliarem se o gestor verifica pontos que devem ser melhorados no sentido de empenhar-se para corrigir eventuais problemas da gestão da saúde, ou, até mesmo, incrementar procedimentos já realizados de maneira satisfatória.

Ainda como exemplo de variáveis que podem ensejar maior participação dos conselheiros é possível citar a variável objetivos e metas para o exercício subsequente e a divulgação de prioridades para a destinação de recursos financeiros. Para Mato Grosso do Sul a Secretaria de Saúde apresentou evidenciação pelo menos parcial deste tipo de informação voluntária, o que permite aos conselheiros de saúde avaliarem se as prioridades apresentadas estão realmente de acordo com as necessidades de saúde do Estado e se os objetivos e metas estão adequadas para o ano seguinte. Sendo assim, a participação dos conselheiros pode encontrar maior facilidade para atuar no cumprimento de suas atribuições. Nesse sentido, a maior qualidade da informação dos relatórios de prestação de contas de Mato Grosso do Sul em face da amplitude de participação social médialaberta do CES encontra como possível justificativa o fato de haver uma atuação mais parceira de outras instâncias de controle no sentido fazer com que o gestor da saúde cumpra as deliberações do Conselho. 


\section{CONSIDERAÇÕES FINAIS}

A pesquisa buscou verificar se a partir de uma maior amplitude de participação social dos Conselhos de Saúde a qualidade da informação dos relatórios de prestações de contas das Secretarias de Saúde do Centro Oeste seria incrementada. Para dar forma ao referido intento foram entrevistados conselheiros estaduais de saúde e analisadas as atas das reuniões plenárias das instâncias participativas para avaliar a tendência de amplitude de participação social dos mesmos. Por outro lado, procedeu-se à análise documental dos relatórios de prestação de contas de 2011 a 2013 para descrever a sua qualidade da informação.

O indicador implantação e departamentalização do Conselho Estadual de Saúde do CES/GO permitiu verificar que a constituição do mesmo foi imposta por legislação, mas passou a ter alguma atividade; que representa o ponto de vista da sociedade sobre as necessidades, mas possui Mesa Diretora, via Secretaria Executiva, responsável pelo encaminhamento das prioridades para discussão - fato que derruba a prioridade inerente das comissões. No tocante à liderança verificou-se que o CES funciona sob um gestor estadual de saúde independente, aspecto que exibe característica de autoritarismo, pois as reinvindicações do Conselho não são acatadas pela Secretaria. Com respeito à mobilização de recursos cabe mencionar que existem contribuições periódicas dos entes federados, mas sem a participação da comunidade no controle dos gastos.

No CES/MT, o indicador implantação e departamentalização permitiu verificar que a constituição do mesmo também foi imposta por legislação, mas passou a ter alguma atividade. Além disso, constatou-se que o Conselho representa a comunidade, diferentemente de Goiás, e avalia as suas necessidades por múltiplos canais, inclusive por meio do estabelecimento de cooperação técnica com os municípios - elemento que vai ao encontro de uma das atribuições do CES, auxiliar e orientar os Conselhos Municipais. Em relação à liderança no CES/MT, também verificou-se que o mesmo funciona sob um gestor estadual de saúde independente - pois muitas deliberações não são homologadas. No tocante à mobilização de recursos foi possível analisar que existem contribuições periódicas dos entes federados, mas, assim como em Goiás, sem a participação da comunidade no controle dos gastos. Novamente, o CES/MT parece somente acompanhar os gastos, ao passo que o gestor atua de maneira independente.

No CES/MS verificou-se que o mesmo foi imposto por legislação, mas passou a ser plenamente ativo e com iniciativa, além de apresentar inciativas pontuais de cooperação com outras organizações da comunidade. Por outro lado, constatou-se que o Conselho, assim como 
em Mato Grosso, representa a comunidade e avalia as suas necessidades por múltiplos canais. Todavia, apesar do resultado similar a Mato Grosso há que se fazer uma distinção pelo fato do ambiente de controle social apresentar maior cooperação com outras instâncias de poder (Ministério Público, por exemplo). Em relação à liderança o CES também funciona sob um gestor estadual de saúde independente - pois, por vezes, as deliberações não são homologadas. No tocante à mobilização de recursos destaca-se que existem contribuições periódicas dos entes federados, mas, assim como nos outros Conselhos, a comunidade não participa do controle de gastos.

O panorama de amplitude de participação exposto nos Conselhos de Saúde do Centro Oeste apresentou-se como passível de melhorias, sobretudo nos aspectos relativos ao controle da aplicação de recursos; na capacidade de fazer com que suas deliberações sejam homologadas pelo governo - conseguir ter voz na Secretaria -, bem como na necessidade de melhoria do ambiente de controle social em relação à cooperação com outras instâncias de poder. Para Amorim (2007) o fato da população participar do processo decisório figura como elemento importante para fortalecer as organizações sociais e instituições políticas, sobretudo quando consideram aspectos da eficácia política e competência cívica. O Autor ainda considera que os conceitos mencionados se referem justamente ao fato do cidadão poder influenciar o aspecto relativo ao processo decisório.

Na esteira desse pensamento, verifica-se que ainda há necessidade de evolução em todos os indicadores de amplitude de participação para alcançar o fortalecimento das instituições políticas, organizações sociais e demais atores do controle social da saúde. Como foi possível constatar, em momento algum os conselhos apresentaram tendência aberta para os indicadores de amplitude de participação social, ou seja, as organizações comunitárias não participaram da criação do CES, a comunidade não interveio na avaliação das necessidades, os Conselhos não representaram toda a diversidade de interesses da comunidade. Além disso, os Conselhos não controlam as atividades do gestor estadual e, por fim, os não decidem como utilizar os recursos dos Fundos da saúde, por exemplo.

Por oportuno, vale mencionar que o ambiente de controle social em face da accountability horizontal existente nos Estados merece destaque na medida em que apresenta cenário cuja interação entre Conselhos, Secretarias, Ministério Público, Tribunal de contas dentre outras instâncias de controle parece não ter apresentado relação de parceria. Para Goiás e Mato Grosso a falta de cooperação das instâncias de poder também pode encontrar justificativa em elementos ligados ao perfil dos conselheiros dos CES, pois a amplitude de participação do Conselho pode, em princípio, ser afetada tanto pela pouca experiência dos 
conselheiros como pela falta de conhecimento da legislação da saúde; da dificuldade de leitura dos relatórios, nível de escolaridade dentre outros fatores.

A qualidade da informação dos relatórios nos aspectos da relevância e materialidade da informação apresentaram tendência restrita para Goiás e Mato Grosso, também pelo fato de não serem apresentados recursos previstos na proposta/lei orçamentária para o exercício seguinte, o que segundo Gonçalves et al. (2011, p. 666) “impossibilita qualquer tipo de planejamento ou reinvindicação por parte do Conselho e também por parte dos próprios profissionais da área”. Além disso, não foram, em ambos os casos, apresentadas metas e objetivos para o ano seguinte, o que também prejudica o planejamento das atividades do Conselho. No caso de Mato Grosso do Sul foi verificada tendência média para relevância e materialidade, diferentemente das outras Secretarias, pois este apresentou metas e objetivos em alguns momentos. Um ponto comum a todas as Secretarias na dimensão da relevância foi a evidenciação dos recursos aplicados com suas respectivas fontes (tendência ampla - divulgação obrigatória).

A dimensão da representação fidedigna da informação apresentou tendência restrita para Goiás e Mato Grosso. Para Mato Grosso do Sul verificou-se tendência média. Para as duas primeiras Secretarias isso implica dizer que o conteúdo dos relatórios não exibiu confiabilidade, sobretudo no tocante à divulgação de prioridades para destinação de recursos para a saúde - fator que indica a falta de critérios do gestor para aplicar recursos de acordo com as necessidades da saúde (GONÇALVES et al., 2013). Além disso, vale mencionar que pontos que necessitam de melhorias (divulgação voluntária) também não foram verificados nos relatórios, indicando, portanto, a falta de conhecimento ou negligência dos gestores no sentido de serem parciais em relação à divulgação desses pontos - ambos aspectos negativos. Já no caso de Mato Grosso do Sul verificou-se resultado diferente, pois além de estabelecer prioridades para destinação de recursos foram divulgados nos relatórios pontos que necessitavam de melhorias, fatores que podem promover o melhor cumprimento das atribuições dos conselheiros.

No caso da dimensão da tempestividade verificou-se o pior cenário, pois os relatórios das três Secretarias, além de não serem encaminhados, por vezes, dentro do prazo legal, não mencionavam a expectativa de disponibilização do relatório seguinte. Duas observações devem ser realizadas em relação a esse ponto: a) informações que não são apresentadas de maneira oportuna perdem a sua relevância, pois em nada contribuem para o processo decisório do CES; e b) o Conselho perde a capacidade de avaliar as ações da SES (GONÇALVES et al., 2011). 
De maneira geral, ao analisar a qualidade da informação - considerando o conjunto de variáveis divulgadas de forma obrigatória, decorrente da obrigatória e de forma voluntária verificou-se que os gestores de Goiás e Mato Grosso cumpriram praticamente só o que é imposto por legislação, demonstrando, dessa forma, que a participação dos Conselhos não foi qualificada a ponto de compelir o gestor a ser mais transparente em relação aos seus atos, bem como de interferir em melhorias para a população. A ausência da divulgação de informações voluntárias reforça a ideia de que a participação não qualificada pode tender a diminuir a qualidade dos relatórios. Dessa forma, o que se esperava como resultado era que quanto maior fosse a amplitude de participação social, maior seria o nível de divulgação de informações.

Em Mato Grosso do Sul houve a divulgação de variáveis voluntárias, inclusive com tendência ampla - divulgação de pontos que necessitam de melhoria - apresentando, assim, um cenário de maior qualidade dos relatórios de prestação de contas. A ideia de que quanto maior fosse a amplitude de participação social, maior seria o nível de divulgação de informações foi corroborada para o caso deste Estado. Para Watson et al. (2002) o disclosure (evidenciação) voluntário vai além das informações requeridas por meio de legislação, normas contábeis ou regulação de órgãos normatizadores. É com esse pano de fundo que se considera a necessidade dos relatórios de prestação de contas divulgarem informações relevantes, além das chamadas informações obrigatórias. Sob esse prisma, Ramanathan (1976), ao abordar a evidenciação social, aspecto aplicável ao contexto desta pesquisa, considera que informações relevantes além de estabelecerem responsabilidade pública devem facilitar o processo de tomada de decisão em relação à aplicação de recursos sociais. Nesse sentido, a divulgação de informações voluntárias e relevantes, por parte das Secretarias de Saúde, para fundamentar o processo decisório poderia ser um indicativo de que a participação dos Conselhos seria qualificada a ponto de incrementar a qualidade dos relatórios.

A partir da análise das entrevistas dos conselheiros, atas, demais documentos e da qualidade dos relatórios de prestações de contas, e seus pareceres, acredita-se ter montado um mosaico de modo a ofertar resposta ao problema desta pesquisa - relativo à possibilidade da amplitude de participação social incrementar a qualidade da informação dos relatórios. $\mathrm{O}$ motivo da exposição da palavra mosaico ocorre justamente pelo fato de que no decorrer da pesquisa verificou-se a necessidade de buscar elementos do ambiente de controle social para contextualizar o porquê de determinadas situações encontradas. Um exemplo seria o fato das tendências de amplitude de participação social de Mato Grosso e Mato Grosso do Sul terem apresentado resultado similar, apesar da qualidade dos relatórios da SES/MS ter sido superior. 
Diante desse quadro, o ambiente de controle social se mostrou condição importante que houvesse ou não uma tendência para que uma maior amplitude de participação social pudesse incrementar a qualidade dos relatórios. No Mato Grosso do Sul o ambiente de maior cooperação entre os atores do controle social fez com que o CES avançasse no cumprimento de suas atribuições, fato que pode justificar a melhora ${ }^{40}$ na qualidade dos relatórios evidenciada chegando a 66\% de variáveis médias (41\%) e amplas (25\%) em 2013. Portanto, foram verificados indícios de que a partir de uma maior amplitude de participação é possível verificar incremento na qualidade dos relatórios, considerando também um ambiente de controle social que estabeleça relação de cooperação com os CES.

A não homologação das deliberações do Conselho por parte dos governos dos Estados exibe cenário o qual padece de cooperação com outras instâncias de poder, pois pelo fato do CES não possuir caráter punitivo, tampouco vinculatório de suas deliberações, o ambiente de controle social da saúde parece não ser favorável à participação social e à possibilidade de incremento da qualidade da informação dos relatórios de prestações de contas. Diante disso, é preciso vislumbrar alternativas para que tanto o ambiente de controle social, quanto a própria transparência das gestões governamentais da saúde possa ser aprimorada, incentivada, fiscalizada e controlada, de modo a atender com maior propriedade às necessidades da saúde.

Em razão dos fatos expendidos até então salienta-se a necessidade, justamente, de se discutir sobre meios para que o controle social, de fato, possa começar a ser trabalhado com o objetivo de tornar a participação social mais presente e com espaço para que a qualidade da informação dos relatórios possa, em determinado momento, ser incrementada. Assim, são propostas as seguintes contribuições ao cenário encontrado na pesquisa, quais sejam:

i. A criação de mídias sociais específicas para os órgãos de controle social no sentido de promover aproximação com a sociedade civil, inclusive com o propósito de instrumentalizar meios para que ela possa se organizar. Esta ferramenta nos dias atuais oferece múltiplas plataformas de interação, que sem dúvida poderiam ser úteis para promover, instigar e orientar ao controle social das ações de saúde. Deve se destacar também que seria um canal para relatar denúncias e sugestões. Uma ideia inicial seria a criação de perfis no

\footnotetext{
${ }^{40} \mathrm{~A}$ evolução da qualidade pode ser verificada no gráfico 06, p. 151.
} 
facebook $^{41}$, twitter e instagram para que os Conselhos e Secretarias fossem monitorados por comissão específica (de caráter permanente). O sentido seria discutir as reais necessidades de saúde com o cidadão, além de avaliar e debater sobre providências em relação as denúncias. Todavia, destaca-se que para isso ocorrer seria necessário apoio do governo federal no intuito de disseminar para os Estados e Municípios;

ii. Conferências Nacionais, Estaduais e Municipais de controle social envolvendo as instâncias de poder ligadas a essa conjuntura (ex: MPF, MPU, TCE, TCU, Procuradorias, Ministério da Saúde dentre outras entidades). O propósito seria realizar uma avaliação preliminar dos entraves encontrados no controle social, sob o prisma de um trabalho em conjunto. Após esse momento proceder-se-ia à elaboração de um Plano Nacional com as diretrizes que deveriam ser seguidas pelas entidades participantes. Por fim, seriam realizadas conferencia para avaliar periodicamente o cenário de controle social com seus diversos atores;

iii. Criação de Promotorias da Saúde, constituídas por magistrados, promotores, procuradores e médicos da saúde pública para discutir e racionalizar temas como a judicialização da saúde e suas várias derivações, bem como atuar para evita-la;

iv. Criação de Ouvidorias próprias, incialmente inseridas nos Conselhos Estaduais de Saúde - por conta da sua melhor estrutura -, assim como no caso do CES/MT, experiência que por sinal se desenvolveu e se firmou como instrumento de avaliação das necessidades da população (canal);

v. Capacitação permanente dos conselheiros de saúde, inclusive no que tange à leitura e interpretação dos relatórios de prestação de contas das Secretarias de Saúde;

vi. Promoção da Accountability Digital - instrumento a ser utilizado, principalmente sob a plataforma da internet - com a finalidade de promover maior transparência às ações dos gestores da saúde, pois na medida em que os cidadãos têm mais acesso a informações e se tornam mais vigilantes, o gestor, por sua vez, se sentirá conduzido a prestar contas de forma mais

\footnotetext{
${ }^{41}$ Exemplos já existentes: Conselho Estadual de Saúde de Goiás <https://www.facebook.com/pages/ConselhoEstadual-de-Sa\%C3\%BAde-de-Goi\%C3\%A1s/274873042549497?fref=ts>; Secretaria de Saúde de Goiânia <https://www.facebook.com/saudegoiania>; Conselho Estadual de Saúde de Mato Grosso <https://www.facebook.com/pages/Conselho-Estadual-De-Saude-De-Mato-Grosso/394040250702948?fref=ts>.
} 
transparente. A forma de operacionalização seria simples, pois já existe legislação que exige que determinados documentos tanto do CES quanto da Secretaria sejam disponibilizados para acesso na internet. Todavia, a própria pesquisa revelou que isso não ocorre como deveria, pois existe uma série de atas que não estavam disponibilizadas para pesquisa. Este fator, inclusive, encontra-se como uma limitação da pesquisa. Nesse sentido, é dever dos referidos órgãos disponibilizar os seguintes documentos, a saber: atas plenárias, relatórios quadrimestrais e anuais, divulgação dos pareceres dos relatórios da SES, divulgação das deliberações e demais documentos que se sejam necessários ao conhecimento dos usuários e demais interessados.

Ainda com relação às propostas, vale ressaltar que cada uma delas pode ser explorada como ponto de partida para pesquisa futuras, dado que são observações adequadas ao cenário atual de controle social dos Estados analisados, até mesmo de uma questão nacional.

De forma geral, aparentemente nos Conselhos de Goiás e Mato Grosso, em razão das características de uma participação não qualificada, não se consegue incrementar melhorias no nível de evidenciação dos relatórios. Já em Mato Grosso do Sul é possível perceber que em razão de um ambiente de maior participação e controle há um espaço que propicia um incremento na qualidade dos relatórios. $\mathrm{O}$ fato da pesquisa ter utilizado a metodologia de estudo de casos múltiplos contribuiu para análise da sua proposta na medida em que apresentou três realidades diferentes. A análise dos três Estados permitiu compreender que a amplitude de participação social dos Conselhos Estaduais de Saúde pode incrementar a qualidade dos relatórios de prestações de contas das Secretarias Estaduais de Saúde, principalmente quando existe ambiente de controle social propício para tal. 


\section{REFERÊNCIAS}

AFONSO, A. J. Políticas avaliativas e accountability em educação — subsídios para um debate iberoamericano. Revista de Ciências da Educação, v. 09, n. 46, p. 57-70, 2000. ISSN 1984932X.

ACKOFF, R. L.; FINNEL, E. V.; GHARAJEDAGHI, J. A guide to controlling your corporation's future. Wiley, 1984. ISBN 0471882135.

ALVES, D. S.; VISCARRA, S. P. Capital social, satisfação e as diferentes formas de participação política. Revista Debates, v. 6, n. 1, p. 85, 2006. ISSN 1982-5269.

ANTÔNIO, H.; DE SALLES VILLAR, M. Dicionário Houaiss da língua portuguesa. Rio de Janeiro: Objetiva, 2001.

ARRETCHE, M. T. Políticas sociais no Brasil: descentralização em um Estado federativo. Revista brasileira de ciências sociais, v. 14, n. 40, p. 111-141, 1999.

ARRETCHE, M. et al. Descentralizaçäo das políticas sociais no Brasil. FAPESP, 1999. ISBN 8572850805.

AVELAR, L.; CINTRA, A. O. Sistema político brasileiro: uma introdução. Unesp, 2007. ISBN 8575041088.

AVRITZER, L. Democracy and the public space in Latin America. New Jersey: Princeton University Press, 2002. ISBN 1400825016.

Sociedade civil, instituições participativas e representação: da autorização à legitimidade da ação. Dados, v. 50, n. 3, p. 443-464, 2007. ISSN 0011-5258.

BARDIN, L.; RETO, L. A.; PINHEIRO, A. Análise de conteúdo. Edições 70, Lisboa, 1979. ISBN 9724400204.

BARROS, A. D., JORGE. Métodos e técnicas de pesquisa em comunicação. 2 ed. São Paulo: Atlas, 2006.

BARROS, E. O controle social e o processo de descentralizaçäo dos serviços de saúde. In: (Ed.). Incentivo a participaçäo popular e controle social no Sus: Textos técnicos para conselheiros de saúde: IEC, 1998. p.29-37.

BRAGA JÚNIOR, D. Relaçöes de trabalho: conflitos, eficiência e democracia: a negociaçäo como instrumento de gestäo no SUS. RASPP Rev. Assoc. Saúde Pública de Piauí, v. 1, n. 2, p. 133-6, 1998. ISSN 1415-5583.

BELKAOUI, A. Accounting theory 5th edition: South-Western Cengage Learning 2000.

BONIZIO, R. C. Um estudo sobre os aspectos relevantes da contabilidade e o seu uso em empresas do setor de construção civil. 2001. 189 f. 2001. Dissertação (Mestrado em Controladoria e Contabilidade)-Programa de Pós-Graduação em Controladoria e Contabilidade, Faculdade de Economia, Administração e Contabilidade da USP, São Paulo 
BORGES, T. J. G. Práticas de Accountability na Administração Pública Brasileira: existe espaço para este Instrumento na Saúde Pública Tupiniquim - via Conselhos de Saúde?. ENCONTRO NACIONAL DA ANPAD, XXXVIII, p. 1-16, 2014.

BRASIL. Constituição da República Federativa do Brasil. Promulgada em 5 de outubro de 1988. Brasília. Disponível em:<http://www.presidencia.gov.br>.

Ministério do Planejamento, Orçamento e Gestão. Orçamento Federal ao Alcance de todos (OAFT). Brasília: Ministério do Planejamento, Orçamento e Gestão, 2013.

Ministério do Desenvolvimento Social e Combate à Fome. Prestação de Contas De Convênios. Brasília: Ministério do Desenvolvimento Social e Combate à Fome, 2014. Disponível em: < http://www.mds.gov.br/falemds/perguntas-frequentes/assistenciasocial/financiamento/convenios-e-contratos-de-repasses/prestacao-de-contas-de-convenios $>$.

Lei Complementar $n^{\circ} 141$, de 13 de janeiro de 2012. Regulamenta o § 3o do art. 198 da Constituição Federal para dispor sobre os valores mínimos a serem aplicados anualmente pela União, Estados, Distrito Federal e Municípios em ações e serviços públicos de saúde; estabelece os critérios de rateio dos recursos de transferências para a saúde e as normas de fiscalização, avaliação e controle das despesas com saúde nas 3 (três) esferas de governo; revoga dispositivos das Leis nos 8.080, de 19 de setembro de 1990, e 8.689, de 27 de julho de 1993; e dá outras providências. Diário Oficial [da República Federativa do Brasil], Brasília, DF, n. 11, 16 jan. 2012. Seção 1.

Lei $n^{\circ}$. 8.142, de 28 de dezembro de 1990. Dispõe sobre a participação da comunidade na gestão do Sistema Único de Saúde (SUS) e sobre as transferências intergovernamentais de recursos financeiros na área da saúde e dá outras providências. Brasília-DF, 28 dez. 1990. Disponível em: 〈http://www.presidencia.gov.br〉.

Lei $\mathrm{n}^{\circ}$ 8.689, de 27 de julho de 1993. Dispõe sobre a extinção do Instituto Nacional de Assistência Médica da Previdência Social (Inamps) e dá outras providências. Diário Oficial [da República Federativa do Brasil], Brasília, DF, n. 142, 28 jul. 1993. Seção 1.

Lei ${ }^{\circ} 12.527$, de 18 de novembro de 2011. Regula o acesso a informações previsto no inciso XXXIII do art. 5ำ no inciso II do $\S 3^{\circ}$ do art. 37 e no $\S 2^{\circ}$ do art. 216 da Constituição Federal; altera a Lei no 8.112, de 11 de dezembro de 1990; revoga a Lei ํㅡㄴ 11.111, de 5 de maio de 2005, e dispositivos da Lei no 8.159 , de 8 de janeiro de 1991; e dá outras providências. Disponível em: < http://www.planalto.gov.br/ccivil_03/_ato2011-2014/2011/lei/112527.htm>.

Decreto n ${ }^{\circ} 7.508$, de 28 de junho de 2011. Regulamenta a Lei no 8.080, de 19 de setembro de 1990, para dispor sobre a organização do Sistema Único de Saúde - SUS, o planejamento da saúde, a assistência à saúde e a articulação interfederativa, e dá outras providências. Diário Oficial [da República Federativa do Brasil], Brasília, DF, n. 123, 29 jun. 2011. Seção 1. 
Ministério da Saúde. Conferência Nacional de Saúde. Relatório Final da $8^{\mathrm{a}}$ Conferência Nacional de Saúde, Brasília-DF, 17 a 21 de março de 1986. Brasília: Ministério da Saúde, 1986.

Ministério da Saúde. Conferência Nacional de Saúde. Relatório Final da $11^{\mathrm{a}}$ Conferência Nacional de Saúde. O Brasil falando como quer ser tratado: efetivando o SUS Acesso, Qualidade e Humanização na Atenção à Saúde com Controle Social, Brasília-DF, 15 a 19 de dezembro de 2000. Brasília: Ministério da Saúde, 2001.

Ministério da Saúde. Conselho Nacional de Saúde Relatório final da $14^{\mathrm{a}}$ Conferência Nacional de Saúde: todos usam o SUS: SUS na seguridade social: Política pública, patrimônio do povo brasileiro. Brasília: Ministério da Saúde, 2012.

. Conselho Nacional de Saúde. Resolução nº 333, de 04 de novembro de 2003. Aprova as diretrizes para criação, reformulação, estruturação e funcionamento dos conselhos de saúde. Brasília-DF. Disponível em: 〈http://www.saude.gov.br〉

Plano Diretor de Reforma do Estado (PDRAE). Define objetivos e estabelece diretrizes para a reforma da administração pública brasileira, instrumento indispensável para consolidar a estabilização e assegurar o crescimento sustentado da economia. Disponível em: $<$ http://www.planejamento.gov.br/editoria.asp?p=editoria\&index=25\&ler=t524 >. Acesso em: 18 jan. 2014.

BRESSER-PEREIRA, L. C. Da administração pública burocrática à gerencial. ENAP, 1996.

Sociedade civil: sua democratização para a reforma do Estado. Sociedade e estado em transformação. São Paulo: UNESP/ENAP, 1999.

CÂMARA, L. M. Apontamentos teóricos para subsídio à análise das práticas de controle social no âmbito dos Conselhos de Administração das Organizações Sociais. Revista de Administração Mackenzie, v. 4, n. 1, 2008. ISSN 1678-6971.

CAMPELO, Karina Simões. Características qualitativas da informação contábil: uma análise do grau de entendimento dos gestores financeiros de empresas do setor elétrico brasileiro. 2007. Dissertação (Mestrado em Ciências Contábeis) - Universidade de Pernambuco, Recife, 2007.

CAMPOS, A. M. Accountability: quando poderemos traduzi-la para o português? Revista de Administração Pública, v. 24, n. 2, p. 30 a 50, 1990.

CARNEIRO, C. B. L. Governança e Accountability: algumas notas introdutórias. Texto para discussão, n. 13, 2004.

CARVALHO, A. I. Conselhos de Saúde no Brasil: participação cidadã e controle social. In: IBAM, 1995, Fase.

CARVALHO, W. A reforma administrativa da Nova Zelândia nos anos 80-90: controle estratégico, eficiência gerencial e accountability. Revista do Serviço Público, v. 48, n. 3, p. p. 5-35, 1997. ISSN 2357-8017.

CHAUÍ, M. Cultura e democracia: o discurso competente e outras falas. 6. São Paulo: Cortez, 1993. ISBN 8524901381. 
CREMONESE, D. A participação como pressuposto da Democracia. Desenvolvimento em Questão, v. 10, n. 19, p. 78-102, 2009. ISSN 2237-6453.

COELHO, V. S. P. A democratização dos Conselhos de Saúde: o paradoxo de atrair não aliados. Novos Estudos-CEBRAP, n. 78, p. 77-92, 2007. ISSN 0101-3300.

CONSTRUCION, A. O controle social e a democratização da informação: um processo em construção. Ver Latino-am Enfarmagem, v. 11, n. 3, p. 376-82, 2003.

CORREIA, M. V. C. Que controle social. Os conselhos de saúde como instrumento. Rio de Janeiro: Fiocruz, 2000.

. Aspectos legais do SUS. Desafios para o controle social: subsídios para capacitação de conselheiros de saúde, 2005.

COMITÊ DE PRONUNCIAMENTOS CONTÁBEIS. CPC O0-PRONUNCIAMENTO CONCEITUAL BÁSICO (R1)-Estrutura Conceitual para Elaboração e Divulgação de Relatório Contábil-Financeiro. 20112013.

CONTROLADORIA GERAL DA UNIÃO - CGU. Cartilha Olho vivo no dinheiro público: um guia para o cidadão garantir os seus direitos. $2^{a}$ edição. Brasília: Gráfica Brasil Editora \& Marketing Ltda, 2009.

CUNHA, R. E. D. Avançando para a Municipalização Plena da Saúde: O que cabe ao Município. In: (Ed.). Avançando para a municipalizaçao plena da saude: o que cabe ao municipio: Brasil. Ministerio da Saude. Secretaria de Assistencia a Saude, 1994.

DEMO, P. Participação é conquista: noções de poder de política social e participativa: São Paulo: Cortez 2001.

ESCOREL, S., MOREIRA, M. R. Participação social. In: (Ed.). Políticas e sistema de saúde no Brasil: Fiocruz, 2008. p.853-883.

FINANCIAL ACCOUNTING STANDARDS BOARD. Statements of financial accounting concepts n. 1: Objectives of Financial Reporting by Business 108 Enterprises. Connecticut: FASB, 1978. Disponível em: <http://www.fasb.org>. Acesso em: 12 jan. 2014.

concepts n. 2: qualitative characteristics of accounting information. Connecticut: FASB, 1980. Disponível em: <http://www.fasb.org>. Acesso em: 12 jan. 2014.

FARIA, C. F. Democracia deliberativa: Habermas, Cohen e Bohman. Lua Nova: Revista de Cultura e Política, p. 47-68, 2000. ISSN 0102-6445. Disponível em: < http://www.scielo.br/scielo.php?script=sci_arttext\&pid=S0102-

64452000000200004\&nrm=iso >.

FERREIRA, A. B. D. H. Mini Aurélio: o dicionário da língua portuguesa. Curitiba: Positivo, 2008. ISBN 8574729590.

FLEURY, S.; LOBATO, L. D. V. C. Participação, democracia e saúde. Rio de Janeiro: Cebes, 2009. 
FUJI, A. H.; SLOMSKI, V. Subjetivismo responsável: necessidade ou ousadia no estudo da contabilidade. Revista Contabilidade \& Finanças, v. 14, n. 33, p. 33-44, 2003. ISSN 15197077.

FUKS, M. Participação e influência política no Conselho Municipal de Saúde de Curitiba. Revista Sociologia e Política, n. 25, 2005.

FUKS, M.; PERISSINOTTO, R. Recursos, decisão e poder: conselhos gestores de políticas públicas de Curitiba. Revista Brasileira de Ciências Sociais, v. 21, n. 60, p. 67-81, 2006. ISSN 0102-6909.

GAVA, E. H. Gestão descentralizada de Serviços de Saúde: o caso da CIMS de Porto Alegre. Porto Alegre, 1992. Dissertação (Mestrado em Administração) Faculdade de Ciências Econômicas. Universidade Federal do Rio Grande do Sul. Porto Alegre, 1992.

GERSCHMAN, S. Conselhos Municipais de Saúde: atuação e representação das comunidades populares Municipal Health Councils: activity and representation of grassroots communities. Cad. Saúde Pública, v. 20, n. 6, p. 1670-1681, 2004.

GIACOMONI, J. A comunidade como instância executora do planejamento: o caso do orçamento participativo de Porto Alegre. Revista de Administração Pública, v. 28, n. 2, p. 47-59, 1994. ISSN 0034-7612.

GIOVANELLA, L. et al. Políticas e sistema de saúde no Brasil. In: (Ed.). Políticas e sistema de saúde no Brasil: Fiocruz, 2008.

GLAUTIER, M. W. E.; UNDERDOWN, B. Accounting theory and practice. Pearson Education, 2001. ISBN 0273651617.

GOHN, M. D. G. Conselhos gestores e participação sociopolítica. In: (Ed.). Questões da nossa época. São Paulo: Cortez, v.84, 2001.

GONÇALVES, A. et al. Da Secretaria de Saúde ao Conselho: análise de relatórios de prestação de contas com base nas características qualitativas da informação contábil. RCO - Revista de Contabilidade e Organizações, v. 4, p. 92-111, 2010.

. TAVARES, A. L. O Olhar dos Conselheiros de

Saúde Sobre os Relatórios de Prestação de Contas no Município de Natal (Rio Grande do Norte), Brasil. Saúde Soc. São Paulo, v.20, n.3, p.659-672, 2011.

WEFFORT, E. F. J. Limites da participação de cidadãos na política pública de saúde: proposta de uma metodologia de avaliação. Revista Eletrônica Gestão \& Saúde. v.03, n.2, p. 674-691, 2012.

Conselhos de saúde e controle social: um estudo comparativo dos relatórios de prestação de contas das Secretarias Estaduais de Saúde. Saúde e Sociedade, v. 22, n. 4, p. 1001-1013, 2013. ISSN 1984-0470.

GRAMSCI, A. Os intelectuais e a organização da cultura. Rio de Janeiro: Civilização Brasileira, 1981. 
GRISOTTI, M.; PATRÍCIO, Z. M.; SILVA, A. D. A participação de usuários, trabalhadores e conselheiros de saúde: um estudo qualitativo. Ciência \& Saúde Coletiva, v. 15, n. 3, p. 831840, 2010. ISSN 1413-8123.

Guber, Rosana. La etnografia: método campo y reflexividad. Buenos Aires: Norma, 2001.

HENDRIKSEN, E. S.; BREDA, M. F.V. Teoria da Contabilidade. Trad. Antônio Zoratto Sanvicente. Tradução de: Accounting theory. São Paulo: Atlas, 2011.

HUANG, K.-T.; LEE, Y. W.; WANG, R. Y. Quality information and knowledge. 1998a. 0130101419.

Quality information and knowledge. Prentice Hall PTR, 1998b. ISBN

INTERNATIONAL ACCOUNTING STANDARDS BOARD. "Framework for the Preparation and Presentation of Financial Statement". IASB: July, 1998. Disponível em: <http://www.ifrs.org>.

INTERNATIONAL FEDERATION OF ACCOUNTANTS. Handbook of International Plublic Sector Accounting Pronouncements. Volume I. IFAC, July, 2013. Disponível em: < http://www.ifac.org/publications-resources/2013-handbook-international-public-sectoraccounting-pronouncements >. Acesso em: 14 jan. 2014.

JOVCHELOVITCH, S. Representações sociais e espaço público: a construção simbólica dos espaços públicos no Brasil [Social representations and public life: the symbolic construction of public spaces in Brazil]. Vozes, 2000. ISBN 8532623468.

LAVALLE, A. G. Participação: valor, utilidade, efeitos e causa. Efetividadedas Instituições Participativasno Brasil: Estratégiasde Avaliação, p. 33, 2011.

LIMA, J. C. D. Descentralização e accountability em uma região de saúde. Saúde debate, v. 27, n. 65, p. 221-233, 2003. ISSN 0103-1104.

LIKERT, R. A Organização Humana. Tradução: Márcio Contrim. São Paulo: Atlas, 1975.

LOCK, Fernando do Nascimento. Participação popular no controle da administração pública: um estudo exploratório. Disponível em:

<http://w3.ufsm.br/revistacontabeis/anterior/artigos/vIn01/a07vIn01.pdf >. Acesso em: 05 nov. 2011.

MALTA, D. C. et al. Lista de causas de mortes evitáveis por intervenções do Sistema Único de Saúde do Brasil. 2007.

MATOS, J. S.; SENNA, A. K. História oral como fonte: problemas e métodos. Historiae, Rio Grande, v. 2, n. 1, p. 95-108, 2011. Disponível em:

<http://www.seer.furg.br/hist/article/view/2395/1286>. Acesso em: 06 abr. 2013

MIGUEL, L. F. Impasses da accountability: dilemas e alternativas da representação política. Revista de Sociologia e Política, v. 25, p. 25-38, 2005. ISSN 0067-964X.

MILANI, C. R. Políticas públicas locais e participação na Bahia: o dilema gestão versus política. Sociologias, v. 8, n. 16, 2006. ISSN 1807-0337. 
MOREIRA, M. R., ESCOREL, S. Acompanhamento dos Conselhos de Saúde: Cadastro dos CMS no Brasil. Rio de Janeiro: Ensp, Fiocruz, 2005.

MOREIRA, H. F.; MICHELS, L. R.; COLOSSI, N. Inclusão educacional para pessoas portadoras de deficiência: um compromisso com o ensino superior. Escritos sobre educação, v. 5, n. 1, p. 19-25, 2006. ISSN 1677-9843.

MORGAN, L. M. Community participation in health: perpetual allure, persistent challenge. Health policy and planning, v. 16, n. 3, p. 221-230, 2001. ISSN 0268-1080.

NAZARIO, D. C.; SILVA, P. F. D.; ROVER, A. J. Avaliação da qualidade da informação disponibilizada no Portal da Transparência do Governo Federal. Revista Democracia Digital e Governo Eletrônico, n. 6, 2012.

NIYAMA, J. K.; SILVA, C. A. T. Teoria da contabilidade. Atlas, 2011. ISBN 9788522461714. Disponível em: < https://books.google.com.br/books?id=G_pDuQAACAAJ $>$.

O 'DONNELL, G. Accountability horizontal e novas poliarquias. Lua Nova: Revista de Cultura e Política, p. 27-54, 1998. ISSN 0102-6445. Disponível em: < http://www.scielo.br/scielo.php?script=sci_arttext\&pid=S0102$64451998000200003 \&$ nrm $=$ iso $>$.

OLIVEIRA, A. D. S. Perspectivas para o controle social e a transparência da administração pública. Prêmio Serzedello Corrêa, 2001.

OLIVEIRA, V. D. D. C. Comunicação, informação e participação popular nos conselhos de saúde. Saúde e sociedade, v. 13, n. 2, p. 56-69, 2004. ISSN 1984-0470.

PACHECO, R. S. Contratualização de resultados no setor público: a experiência brasileira e o debate internacional. Congresso Internacional del Clad sobre la Reforma del Estado y de la Administración Pública, 2004.

PAIM, J. S.; TEIXEIRA, C. F. Configuração institucional e gestão do Sistema Único de Saúde: problemas e desafios. Ciência \& saúde coletiva, v. 12, p. 1819-1829, 2007. ISSN 1413-8123.

PAULO, E. Comparação da estrutura conceitual da contabilidade financeira: Experiência brasileira, norte-americana e internacional. 2002. 176 f. $2002 . \quad$ Dissertação (Mestrado Multiinstitucional e Inter-Regional em Ciências Contábeis).-Universidade de Brasília (UNB), Universidade Federal da Paraíba (UFPB), Universidade Federal de Pernambuco (UFPE), Universidade Federal do Rio Grande do Norte (UFRN), João Pessoa.

PINHO, J. A. G. D. Investigando portais de governo eletrônico de estados no Brasil: muita tecnologia, pouca democracia. Revista de Administração Pública, v. 42, n. 3, p. 471-493, 2008 .

PINHO, J. A. G. D.; SACRAMENTO, A. R. S. Accountability: já podemos traduzi-la para o português? Revista de Administração Pública, v. 43, n. 6, p. 1343 a 1368, 2009. ISSN 00347612.

PUTNAM, H. Una reconsideración de la democracia de Dewey. Cómo renovar la filosofía, p. 247-271, 1994. 
RAMANATHAN, K. V. Toward a theory of corporate social accounting. Accounting Review, p. 516-528, 1976. ISSN 0001-4826.

RIFKIN, S. B.; BICHMANN, W.; SHRESTHA, M. Cómo medir la participación de la comunidad. Foro Mundial de la Salud (OMS), v. 10, n. 3/4, p. 482-8, 1989. ISSN 0257-3024.

REGOSO, E. L. et al. A GESTAO PÚBLICA TRANSPARENTE POR MEIO DA PARTICIPAÇÃO POPULAR-UM ESTUDO DE CASO. Universidade Comunitária Reginal de Chapecó.

REZENDE, Ricardo Borges. Processo de prestação de contas e controle social por meio de pesquisa participante: uma análise do conselho municipal de saúde de Anápolis/GO. Brasília, 2013. Dissertação (Mestrado em Ciências Contábeis). Universidade de Brasília. Brasília 2013.

ROJO, R. E.; MILANI, C. R.; ARTURI, C. S. Expressions of international contestation and mechanisms of democratic control. International Social Science Journal, v. 56, n. 182, p. 615-628, 2004. ISSN 1468-2451.

RUEDIGER, M. A. Governo eletrônico ou governança eletrônica-conceitos alternativos no uso das tecnologias de informação para o provimento de acesso cívico aos mecanismos de governo e da reforma do Estado. VII Congresso del CLAD, 2002.

SARRETA, F. O.; BERTANI, I. F. Perspectivas da educação permanente em saúde. Revista Ibero-Americana de Estudos em Educação, v. 4, n. 3, 2010. ISSN 1982-5587.

SCHEDLER, A. Conceptualizing accountability. The self-restraining state: Power and accountability in new democracies, p. 13-28, 1999.

SCHROEDER, R.; CLARK, M.; CATHEY, J. Accounting theory and analysis. Chapel Hill: University of North Carolina, 2001.

SILVA, A. O. A Amplitude da Participação da Comunidade no Conselho Municipal de Saúde de Porto Alegre (RS): a visão dos conselheiros. Porto Alegre, 1999. Dissertação (Mestrado em Administração) Escola de Administração. Universidade Federal do Rio Grande do Sul. Porto Alegre, 1999.

SILVA, A. O. Comunidades Participativas e a Deliberação da Política pública de Saúde: Um Estudo Comparativo de Conselhos Locais de Saúde de Porto Alegre (Brasil) e Montevidéu (Uruguai). São Paulo, 2005. Tese (Doutorado em Integração da América Latina). Universidade de São Paulo. São Paulo, 2005.

SILVA, A. X.; CRUZ, E. A.; MELO, V. A importância estratégica da informação em saúde para o exercício do controle social. Ciência \& Saúde Coletiva, v. 12, n. 3, p. 683-688, 2007. ISSN 1413-8123.

SILVA, A. H.; FOSSÁ, M. I. T. PRÁTICAS DE RESPONSABILIDADE SOCIAL CORPORATIVA: A PERCEPÇÃO DOS COLABORADORES DE UMA EMPRESA FAMILIAR. Desenvolve, v. 3, n. 1, p. p. 209-226, 2013. ISSN 2316-5537.

SMITH, M. Research methods in accounting. Sage, 2011.

SMULOVITZ, C.; PERUZZOTTI, E. Societal Accountability in Latin America. Journal of democracy, v. 11, n. 4, p. 147-158, 2000. ISSN 1086-3214. 
STRONG, D. M.; LEE, Y. W.; WANG, R. Y. Data quality in context. Communications of the ACM, v. 40, n. 5, p. 103-110, 1997. ISSN 0001-0782.

TELLES, V. D. S. Direitos sociais: afinal do que se trata? Editora UFMG, 1999. ISBN 8570411820.

VASCONCELOS, Y. L.; VIANA, A. L.; KRAEMER, M. E. P. Evidenciação: forma e qualidade. Revista Brasileira de Contabilidade.-Ano XXXI, n. 134, 2002.

WATSON, A.; SHRIVES, P.; MARSTON, C. Voluntary disclosure of accounting ratios in the UK. The British Accounting Review, v. 34, n. 4, p. 289-313, 2002. ISSN 0890-8389. 
ANEXO A - Roteiro de entrevista do instrumento de Amplitude de Participação Social

Retirado e adaptado de Silva (1999) e Baseado em Rifkin et al. (1988) e Demo (1996).

1. Avaliação de Necessidades: examinar quem ou que pessoas intervieram no planejamento municipal de saúde (ou diagnóstico), em que medida essas pessoas participaram, como as necessidades foram identificadas.

a) Como se identificaram tais necessidades.

b) A identificação dessas necessidades se referem exclusivamente às necessidades em matéria de saúde.

2. Liderança: averiguar que tipo de liderança é exercido no Conselho Municipal de Saúde (CES), que tipo de interesses representam, em que medida a liderança responde às necessidades da comunidade, que tipo de melhora produziram as decisões do CES.

a) A que grupos representam os líderes do CES/MT.

b) Se a liderança do CES responde às necessidades da comunidade.

c) Se decisões do CES produziram melhoria na comunidade em geral .

3. Implantação e Departamentalização: como foi implantado o CES; saber se o CES propõe criar novas estruturas ou integrar os programas de saúde nas existentes, se foram criadas novas organizações na comunidade, se as organizações são rígidas ou flexíveis, que mudanças foram produzidas no CES.

a) À medida que vão surgindo novas demandas, o CES procura criar comissões para efetuar estudos sobre essas necessidades.

b) Se as comissões existentes dentro do CES são flexíveis em captar demandas.

c) As mudanças ocorridas no CES beneficiam os profissionais de saúde ou toda a comunidade e como.

4. Mobilização de Recursos: Determinar em que medida foram obtidos recursos, a que interesses responde a destinação de recursos.

a) Se os Governos Federal, Estadual, Municipal garantem o repasse de recursos destinados para a saúde conforme a previsão orçamentária.

b) Se a forma de distribuição de recursos procura atender o Plano Estadual de Saúde. 
ANEXO B - Instrumento de avaliação dos relatórios de prestação de contas e critérios para avaliação do conteúdo avaliado pelas variáveis - Dimensão Materialidade

\begin{tabular}{|c|c|c|c|c|c|}
\hline \multicolumn{6}{|c|}{ DIMENSÃO: MATERIALIDADE } \\
\hline INDICADOR & $\begin{array}{l}\text { VARIÁVEIS } \\
\text { PROPOSTAS }\end{array}$ & RESTRITA & BAIXA & MÉDIA & AMPLA \\
\hline $\begin{array}{c}\text { Dados } \\
\text { quantitativos }\end{array}$ & $\begin{array}{l}\text { Evidenciação da } \\
\text { aplicação dos } \\
\text { recursos } \\
\text { financeiros }\end{array}$ & Não divulga & $\begin{array}{c}\text { Não } \\
\text { evidencia, } \\
\text { mas } \\
\text { reconhece a } \\
\text { necessidade } \\
\text { de passar a } \\
\text { evidenciar. }\end{array}$ & $\begin{array}{l}\text { Evidencia os recursos } \\
\text { aplicados sem apresentar } \\
\text { o detalhamento do } \\
\text { montante aplicado no } \\
\text { trimestre em análise e/ou } \\
\text { não evidencia } \\
\text { detalhando por ações e } \\
\text { programas de governo. }\end{array}$ & $\begin{array}{l}\text { Evidencia os recursos } \\
\text { aplicados detalhando- } \\
\text { os por ações e } \\
\text { programas de governo } \\
\text { e, ainda, o montante } \\
\text { aplicado no trimestre } \\
\text { em análise. }\end{array}$ \\
\hline $\begin{array}{c}\text { Itemização dos } \\
\text { dados } \\
\text { financeiros }\end{array}$ & $\begin{array}{l}\text { Especificação da } \\
\text { fonte dos } \\
\text { recursos } \\
\text { financeiros }\end{array}$ & Não divulga & $\begin{array}{l}\text { Não } \\
\text { evidencia, } \\
\text { mas } \\
\text { reconhece a } \\
\text { necessidade } \\
\text { de passar a } \\
\text { evidenciar. }\end{array}$ & $\begin{array}{l}\text { Evidencia os recursos } \\
\text { por fonte, mas não } \\
\text { especifica o quantitativo } \\
\text { referente ao trimestre em } \\
\text { análise, disponibilizando } \\
\text { apenas o acumulado do } \\
\text { exercício financeiro. }\end{array}$ & $\begin{array}{c}\text { Evidencia as fontes e o } \\
\text { quantitativo de cada } \\
\text { uma discriminando o } \\
\text { total de recursos } \\
\text { disponibilizados por } \\
\text { trimestre e o } \\
\text { acumulado do exercício } \\
\text { financeiro. }\end{array}$ \\
\hline $\begin{array}{c}\text { Relações SMS } \\
\text { e o Conselho de } \\
\text { Saúde }\end{array}$ & $\begin{array}{l}\text { Participação do } \\
\text { Conselho nas } \\
\text { decisões da } \\
\text { Secretaria de } \\
\text { Saúde }\end{array}$ & Não divulga & $\begin{array}{l}\text { Não } \\
\text { evidencia, } \\
\text { mas } \\
\text { reconhece a } \\
\text { necessidade } \\
\text { de passar a } \\
\text { evidenciar. }\end{array}$ & $\begin{array}{l}\text { Evidencia se acatou ou } \\
\text { não as recomendações } \\
\text { do Conselho, mas não } \\
\text { evidencia o porquê. }\end{array}$ & $\begin{array}{c}\text { Evidencia se acatou ou } \\
\text { não as recomendações } \\
\text { do Conselho e } \\
\text { evidencia o porquê }\end{array}$ \\
\hline $\begin{array}{c}\text { Planos e } \\
\text { expectativas } \\
\text { relevantes da } \\
\text { administração }\end{array}$ & $\begin{array}{l}\text { Objetivos e } \\
\text { metas para o } \\
\text { exercício } \\
\text { subseqüente }\end{array}$ & Não divulga & $\begin{array}{l}\text { Não } \\
\text { evidencia, } \\
\text { mas } \\
\text { reconhece a } \\
\text { necessidade } \\
\text { de passar a } \\
\text { evidenciar. }\end{array}$ & $\begin{array}{l}\text { Evidencia os objetivos e } \\
\text { as metas, mas não } \\
\text { justifica cada objetivo e } \\
\text { meta estabelecidos. }\end{array}$ & $\begin{array}{c}\text { Planos e expectativas } \\
\text { relevantes da } \\
\text { administração }\end{array}$ \\
\hline
\end{tabular}

Fonte: Gonçalves et al (2010) 
ANEXO C - Instrumento de avaliação dos relatórios de prestação de contas e critérios para avaliação do conteúdo avaliado pelas variáveis - Dimensão Relevância

\begin{tabular}{|c|c|c|c|c|c|}
\hline \multicolumn{6}{|c|}{ DIMENSÃO: RELEVÂNCIA } \\
\hline INDICADOR & $\begin{array}{l}\text { VARIÁVEIS } \\
\text { PROPOSTAS }\end{array}$ & RESTRITA & BAIXA & MÉDIA & AMPLA \\
\hline Valor preditivo & $\begin{array}{l}\text { Recursos } \\
\text { financeiros } \\
\text { previstos na } \\
\text { proposta/lei } \\
\text { orçamentária }\end{array}$ & Não divulga & $\begin{array}{l}\text { Não } \\
\text { evidencia, } \\
\text { mas } \\
\text { reconhece a } \\
\text { necessidade } \\
\text { de passar a } \\
\text { evidenciar. }\end{array}$ & $\begin{array}{l}\text { Comenta a proposta/lei } \\
\text { orçamentária, mas não } \\
\text { especifica as previsões } \\
\text { para os créditos e } \\
\text { dotações orçamentárias. }\end{array}$ & $\begin{array}{c}\text { Evidencia } \\
\text { especificando o } \\
\text { quantitativo previsto } \\
\text { para cada ação e } \\
\text { programa de governo, } \\
\text { para a área da saúde, } \\
\text { previstos na } \\
\text { proposta/lei } \\
\text { orçamentária. }\end{array}$ \\
\hline $\begin{array}{c}\text { Valor } \\
\text { confirmativo }\end{array}$ & $\begin{array}{l}\text { Confronto dos } \\
\text { resultados } \\
\text { obtidos com as } \\
\text { metas } \\
\text { estabelecidas } \\
\text { para a área da } \\
\text { saúde }\end{array}$ & Não divulga & $\begin{array}{l}\text { Não } \\
\text { evidencia, } \\
\text { mas } \\
\text { reconhece a } \\
\text { necessidade } \\
\text { de passar a } \\
\text { evidenciar. }\end{array}$ & $\begin{array}{l}\text { Evidencia os resultados } \\
\text { obtidos, mas não } \\
\text { justifica aquelas metas } \\
\text { que não foram } \\
\text { alcançadas. }\end{array}$ & $\begin{array}{l}\text { Evidencia os resultados } \\
\text { obtidos e justifica } \\
\text { aquelas metas que não } \\
\text { foram alcançadas }\end{array}$ \\
\hline
\end{tabular}

Fonte: Gonçalves et al (2010) 
ANEXO D - Instrumento de avaliação dos relatórios de prestação de contas e critérios para avaliação do conteúdo avaliado pelas variáveis - Dimensão da Representação Fidedigna

\begin{tabular}{|c|c|c|c|c|c|}
\hline \multicolumn{6}{|c|}{ DIMENSÃO: REPRESENTAÇÃO FIDEDIGNA } \\
\hline INDICADOR & $\begin{array}{l}\text { VARIÁVEIS } \\
\text { PROPOSTAS }\end{array}$ & RESTRITA & BAIXA & MÉDIA & AMPLA \\
\hline Precisão & $\begin{array}{l}\text { Evidenciação do } \\
\text { conteúdo legal }\end{array}$ & Não divulga & $\begin{array}{l}\text { Não } \\
\text { evidencia, } \\
\text { mas } \\
\text { reconhece a } \\
\text { necessidade } \\
\text { de passar a } \\
\text { evidenciar. }\end{array}$ & $\begin{array}{l}\text { Divulga, mas deixa de } \\
\text { divulgar a um ou mais } \\
\text { itens exigidos pela } \\
\text { legislação. }\end{array}$ & $\begin{array}{l}\text { Apresenta todo o } \\
\text { conteúdo legal de } \\
\text { forma a especificar } \\
\text { todos os itens. }\end{array}$ \\
\hline $\begin{array}{c}\text { Valor } \\
\text { descritivo e } \\
\text { mensurável }\end{array}$ & $\begin{array}{l}\text { Previsão de } \\
\text { recursos para os } \\
\text { exercícios } \\
\text { compreendidos } \\
\text { no PPA para a } \\
\text { área da saúde }\end{array}$ & Não divulga & $\begin{array}{l}\text { Não } \\
\text { evidencia, } \\
\text { mas } \\
\text { reconhece a } \\
\text { necessidade } \\
\text { de passar a } \\
\text { evidenciar. }\end{array}$ & $\begin{array}{l}\text { Evidencia os programas } \\
\text { previstos no PPA, mas } \\
\text { não especifica os } \\
\text { recursos previstos. }\end{array}$ & $\begin{array}{l}\text { Evidencia os } \\
\text { programas previstos no } \\
\text { PPA e especifica a } \\
\text { previsão de recursos } \\
\text { correspondentes. }\end{array}$ \\
\hline Conteúdo & $\begin{array}{c}\text { Retificações } \\
\text { orçamentárias }\end{array}$ & Não divulga & $\begin{array}{l}\text { Não } \\
\text { evidencia, } \\
\text { mas } \\
\text { reconhece a } \\
\text { necessidade } \\
\text { de passar a } \\
\text { evidenciar. }\end{array}$ & $\begin{array}{l}\text { Evidencia os } \\
\text { remanejamentos que } \\
\text { ocorreram, mas não } \\
\text { evidencia o montante de } \\
\text { recursos e os respectivos } \\
\text { programas e ações de } \\
\text { governo envolvidos. }\end{array}$ & $\begin{array}{l}\text { Evidencia e especifica } \\
\text { o quantitativo de } \\
\text { recursos realocados } \\
\text { explicitando as ações e } \\
\text { programas de governo } \\
\text { envolvidos e o impacto } \\
\text { em cada um; ou afirma } \\
\text { não existirem, no } \\
\text { período, retificações } \\
\text { orçamentárias. }\end{array}$ \\
\hline Conteúdo & $\begin{array}{l}\text { Divulgação das } \\
\text { prioridades para } \\
\text { destinação dos } \\
\text { recursos } \\
\text { financeiros }\end{array}$ & Não divulga & $\begin{array}{l}\text { Não } \\
\text { evidencia, } \\
\text { mas admite a } \\
\text { necessidade } \\
\text { de passar a } \\
\text { evidenciar. }\end{array}$ & $\begin{array}{l}\text { Afirma estabelecer } \\
\text { prioridades para a } \\
\text { execução orçamentária, } \\
\text { mas não evidencia tais } \\
\text { prioridades. }\end{array}$ & $\begin{array}{l}\text { Afirma estabelecer } \\
\text { prioridades na } \\
\text { execução orçamentária } \\
\text { e as especifica }\end{array}$ \\
\hline Neutralidade & $\begin{array}{l}\text { Divulgação dos } \\
\text { pontos que } \\
\text { necessitam de } \\
\text { melhorias }\end{array}$ & Não divulga & $\begin{array}{l}\text { Não } \\
\text { evidencia, } \\
\text { mas admite a } \\
\text { necessidade } \\
\text { de passar a } \\
\text { evidenciar. }\end{array}$ & $\begin{array}{l}\text { Discorre acerca dos } \\
\text { acerca dos problemas } \\
\text { encontrados naqueles } \\
\text { resultados que não } \\
\text { alcançaram as metas } \\
\text { estabelecidas, mas não } \\
\text { evidencia quais os } \\
\text { impactos na gestão e/ou } \\
\text { não diz quais medidas } \\
\text { deseja tomar para } \\
\text { extinguir o(s) } \\
\text { problema(s). }\end{array}$ & $\begin{array}{l}\text { Discorre acerca dos } \\
\text { acerca dos problemas } \\
\text { encontrados naqueles } \\
\text { resultados que não } \\
\text { alcançaram as metas } \\
\text { estabelecidas, } \\
\text { evidencia os impactos } \\
\text { na gestão e quais } \\
\text { medidas pretende } \\
\text { tomar no sentido de } \\
\text { solucionar o(s) } \\
\text { problema(s). }\end{array}$ \\
\hline
\end{tabular}

Fonte: Gonçalves et al (2010) 